UNIVERSIDADE DE SÃO PAULO

FACULDADE DE FILOSOFIA LETRAS E CIÊNCIAS HUMANAS

DEPARTAMENTO DE SOCIOLOGIA

\title{
ENTRE O DESALENTO E A INVENÇÃO: experiências de desemprego em São Paulo
}

\author{
Fabiana Augusta Alves Jardim \\ Orientadora: Prof. Dra. Heloísa Helena \\ Teixeira de Souza Martins
}

\begin{abstract}
Dissertação de mestrado apresentada ao Programa de Pós-graduação em Sociologia, Faculdade de Filosofia Letras e Ciências Humanas da Universidade de São Paulo para a obtenção do título de Mestre em Sociologia
\end{abstract}

São Paulo

2004 
UNIVERSIDADE DE SÃO PAULO

FACULDADE DE FILOSOFIA LETRAS E CIÊNCIAS HUMANAS

DEPARTAMENTO DE SOCIOLOGIA

\section{ENTRE O DESALENTO E A INVENÇÃO: \\ EXPERIÊNCIAS DE DESEMPREGO EM SÃO PAULO}

Fabiana Augusta Alves Jardim 
Índice

AGRADECIMENTOS

RESUMO

\begin{tabular}{ll}
\hline ABSTRACT & 10 \\
\hline
\end{tabular}

INTRODUĊ̃̃O

CAPÍTULO 1 - O PROBLEMA DA MENSURACC̃̃O

PME E PED - AS FORMAS BRASILEIRAS DE MEDIR 31

CAPÍTULO 2 - PROCEDIMENTOS DE PESQUISA

$\begin{array}{ll}\text { A CONSTITUIÇÃO DO CAMPO } & 62\end{array}$

O CENTRO de Solidariedade de OSASCO 65

$\begin{array}{ll}\text { O INÍCIO DO TRABALHO DE CAMPO } & 67\end{array}$

PROBLEMATIZAR A CONDIÇÃO DE PESQUISADORA 73

A SELEÇÃO DAS NARRATIVAS DE TRABALHO

$\begin{array}{ll}\text { ACHADOS DE CAMPO } & \mathbf{7 8}\end{array}$

$\begin{array}{ll}\text { O UNIVERSO DOS ENTREVISTADOS } & 79\end{array}$

TIPO DE DESEMPREGO $\quad 80$

CAPÍTULO 3 - UMA VIDA DE TRABALHO

I - OS CAMINHOS DE JOSÉ

TRAJETÓRIA DE TRABALHO 88

A CIDADE E AS ILUSÕES 96

CONSTRUINDO A VIDA JUNTOS: A IMPORTÂNCIA DO TRABALHO FEMININO 103

TRABALHADOR SEM PROFISSÃO, SEM FUNÇÃO 107

“GANHARÁS O PÃO COM O SUOR DE TEU ROSTO”: O TRABALHO COMO HORIZONTE 112

O QUE É ESTAR DESEMPREGADO? - O CONHECIMENTO DE QUEM EXPERIMENTA 116

AS NOVAS FORMAS DE PROCURAR: A CONSTRUÇÃO DO DESALENTO 118

CAPÍTULO 4 - MULHER É DESDOBRÁVEL? 123

I - VIVENDO A PERDA DO EMPREGO FORMAL - MARIA DE FÁTIMA 126

$\begin{array}{lr}\text { TRAJETÓRIA DE TRABALHO } & 128\end{array}$

$\begin{array}{ll}\text { A IMPORTÂNCIA DO EMPREGO } & 134\end{array}$

$\begin{array}{ll}\text { O TRABALHO E A APROPRIAÇÃO DO ESPAÇO } & 140\end{array}$

VESTINDO A CAMISA: A IMPORTÂNCIA DO UNIFORME 145

POUPANÇA, PREVIDÊNCIA, SEGURIDADE: CONSTRUIR AS GARANTIAS PARA O FUTURO 148

$\begin{array}{ll}\text { ESSES JOVENS DE HOJE... } & 151\end{array}$ 
DESEMPREGO COMO DOENÇA - ENTENDENDO AS CAUSAS E RECONHECENDO OS SINTOMAS

II - SEM TEMPO PARA NADA - MARIA SUELY

TRAJETÓRIA DE TRABALHO 165

$\begin{array}{ll}\text { A EXPERIÊNCIA DO DESEMPREGO PROLONGADO } & 173\end{array}$

MULHER, SIM: MAS O QUE É ISSO MESMO? 179

$\begin{array}{lr}\text { SER MÃE E TRABALHAR } & 182\end{array}$

$\begin{array}{ll}\text { JOVIALIDADE E APARÊNCIA: PRECONCEITOS } & 186\end{array}$

$\begin{array}{ll}\text { A IMPOSSIBILIDADE DO DESCANSO } & 188\end{array}$

CAPÍTULO 5 - POR FORA DOS TRILHOS: A LIDA DOS PRIMEIROS \begin{tabular}{lr}
\hline EMPREGOS & 192 \\
\hline
\end{tabular}

I - ENTRE A SORTE E O MERECIMENTO - MÁRIO 198

II - “AGORA É SÓ AGUARDAR” - ALESSANDRA 222

III - ENTRE O SONHO E A REALIDADE: LUTEMBERG

IV - A VIDA É COISA SÉRIA - RODOLFO

COMENTÁRIOS FINAIS $\quad 249$

ENTRE O DESALENTO E A INVENÇÃO: DE TUDO, FICA UM POUCO? 249

REFERÊNCIAS BIBLIOGRÁFICAS $\quad 266$

$\begin{array}{lr}\text { NotíCIAS } & 274\end{array}$

ANEXOS $\quad 276$

1. ROTEIROS DE ENTREVISTA 276

1.1. ROTEIRO PARA PRIMEIRA ENTREVISTA 276

1.2. ROTEIRO PARA ENTREVISTA COM FÁTIMA 277

1.3. ROTEIRO PARA ENTREVISTA COM JOSÉ 280

1.4. ROTEIRO PARA ENTREVISTA COM SUELY 282 


\section{ÍNDICE DE TABELAS}

TABELA 1: COMPARAÇÃO ENTRE TAXAS DE DESEMPREGO TOTAL, REGIÃO

Metropolitana de São Paulo. MÉdia AnUAL (EM \%) ................................................ 32

GRÁFICO 1 - EVOLUÇÃO DO DESEMPREGO, POR TIPO (EM \%) ...................................... 43

TABELA 2: TEMPO DE PROCURA, POR TIPO DE DESEMPREGO - 1989 E 2001 (EM \%) ....... 46

TABELA 3: FAIXA ETÁRIA, POR TIPO DE DESEMPREGO, MAIS INATIVOS - 1989 E 2001 (EM $\%)$

TABElA 3B: FAIXA ETÁRIA DE 40 ANOS E MAIS, POR TIPO DE DESEMPREGO - 1989 E 2001 $(\mathrm{EM} \%)$ 50

TABElA 4: SEXO, POR TIPO DE DESEMPREGO, MAIS INATIVOS - 1989 E 2001 (EM \%) ..... 51 TABEla 4A: COMPOSIÇÃO DO DESEMPREGO ABERTO, POR SEXO E FAIXA ETÁRIA, 1989 E $2001(\mathrm{EM} \%)$. 53

TABELA 4B: COMPOSIÇÃO DO DESEMPREGO OCULTO PELO TRABALHO PRECÁRIO, POR SEXO E FAIXA ETÁRIA, 1989 E 2001 (EM \%). 54

TABELA 4C: COMPOSIÇÃO DO DESEMPREGO OCULTO PELO DESALENTO, POR SEXO E FAIXA ETÁRIA, 1989 E 2001 (EM \%)

TABELA 5: NíVEL DE ESCOLARIDADE, POR TIPO DE DESEMPREGO, MAIS INATIVOS - 1989 E $2001(\mathrm{EM} \%)$ 58

TABELA 6 - ENTREVISTADOS, POR SITUAÇÃO OCUPACIONAL (EM \%) .............................. 80

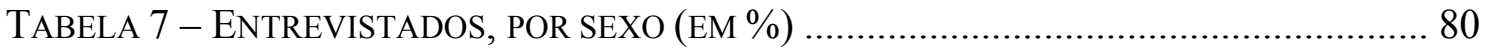

TABELA 8 - ENTREVISTADOS, POR SEXO E TIPO DE DESEMPREGO (EM \%)....................... 81

TABELA 9 - ENTREVISTADOS, POR GRAU DE ESCOLARIDADE (EM \%) .............................. 81

TABELA 10 - ENTREVISTADOS, POR FAIXA ETÁRIA (EM \%) ............................................. 82

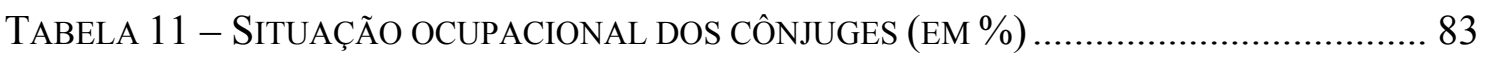

\section{ÍNDICE DE QUADROS E GRÁFICOS}

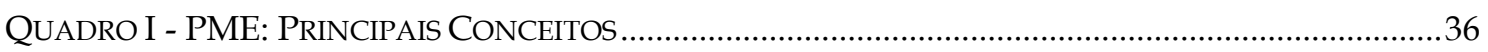

QUADRO II- COMBINAÇÃO DOS PARÂMETROS PARA DEFINIR A CONDIÇÃO DE ATIVIDADE DA PIA.......39

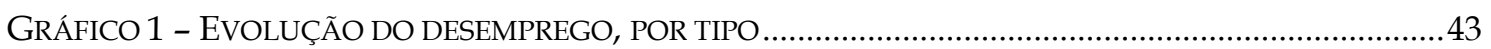

GRÁFICO 2 - ÍNDICE DE CRESCIMENTO DAS TAXAS DE DESEMPREGO, POR TIPO $(1985=100) \ldots \ldots \ldots \ldots . . . . . . . . .44$ 


\section{AGRADECIMENTOS}

Agradeço à FAPESP, pela bolsa e pela obrigação da entrega de relatórios, que tornaram meu trabalho mais disciplinado e provocaram o esforço constante de escrever, concretizando os caminhos percorridos durante a pesquisa; agradeço também ao parecerista, que contribuiu com seus comentários e, principalmente, com sua cobrança para que o trabalho respondesse às perguntas que inicialmente propunha;

Cabe também aqui um agradecimento especial ao Centro de Solidariedade de Osasco - ao Douglas e à Ivanir e à Adriana, psicólogas que sempre me receberam com carinho e abertura para conversas e trocas importantes. Posteriormente, Marta também foi muito compreensiva com minhas visitas ao Centro, gentilmente me ajudando a encontrar lugares tranqüilos para a gravação das entrevistas.

Ao Departamento de Sociologia, agradeço especialmente à Ângela e à Juliana, que sempre estiveram lá para fazer avançar os trâmites burocráticos e para dividir a angústia com datas e prazos;

Durante o período de graduação, devo agradecimentos especiais à Maria Helena Oliva Augusto, cuja disponibilidade e generosidade em orientar seus alunos para além do espaço da sala de aula foi um importante estímulo para despertar em mim a vontade de pesquisar;

A José de Souza Martins, certamente devo esse impulso para o trabalho de campo. Seu rigor de pesquisador e no cuidado da interpretação, sua integridade como professor e mestre, deixaram marcas profundas no meu modo de compreender o fazer sociológico e também na maneira de procurar enxergar $o$ outro;

Maria Arminda Nascimento Arruda foi minha primeira orientadora, durante três anos de iniciação cientifica. Seu rigor e sua paixão me ensinaram muito sobre o processo de pesquisa e também sobre o cuidado com as relações humanas; 
Ao professor Joaquim Alves de Aguiar, o Juca, meu orientador pelo breve período em que estive como mestranda na Teoria Literária, agradeço pela acolhida generosa e também pela tranqüilidade quando da decisão de retornar à Sociologia. Ele não apenas me orientou para a leitura das crônicas de Drummond, mas também - com seu constante perguntar - me ajudou a reconhecer que minhas inquietações estavam em outro lugar;

À Leny Sato, agradeço as críticas, comentários e sugestões durante o exame de qualificação. Os pontos levantados por sua leitura me ajudaram a rever os pesos e as medidas que estruturavam o texto, identificando e evidenciando as regiões imantadas das minhas (várias) questões;

À Nadya Araújo Guimarães, agradeço a disposição com que me recebeu, como ouvinte em suas aulas, pelas críticas e comentários no exame de qualificação e, principalmente, pela exemplar postura intelectual, aberta ao diálogo;

Ao Álvaro Comin agradeço a paciente escuta de minhas inseguranças e crises, geralmente em momentos chave desse percurso, bem como os conselhos e a leitura cuidadosa de muitos pedaços desta dissertação;

Ao Grupo de Estudos do Trabalho, composto de pessoas tão queridas, agradeço a oportunidade de constituição de um espaço de troca pois, se nossas leituras até agora foram dos clássicos, as conversas e debates ao fim das reuniões se preocupavam com o presente, na tentativa de sua decifração. Marco, Rosi, Uvanderson, Inês, Carla, Adriana, Fábio e Wilson, além da Heloísa, representam um dos aspectos mais importantes do trabalho intelectual: a troca e a partilha de inquietações. Dentre essas pessoas tão queridas, é preciso falar especialmente de Maria Inês Caetano: sua competência como socióloga e pesquisadora só faz páreo com sua capacidade de ser companheira e conviver com ela é um privilégio;

Dos tempos de graduação algumas companhias são tão essenciais que é preciso lembrá-las aqui: Emílio Boyago Jardim, com quem dividi as primeiras descobertas tanto em relação à sociologia quanto em relação à vida; muitos trabalhos de fim de semestre foram dedicados a ele, no esforço, sempre 
insuficiente, de reconhecer e agradecer a tudo o que ele representa em minha vida. Ana Lúcia de Freitas Teixeira, amiga tão querida com quem tanto também é dividido: sua presença em minha vida sem dúvida é das mais fundamentais para meu enraizamento nessa cidade - nossos passeios pelo centro, o convívio próximo e, aquilo que ela nomeou, muito propriamente, como nossas leituras a quatro mãos, todas essas coisas se entrelaçam tão fortemente à constituição do que sou que seria impossível dissociá-las. Mauricio Pelegrini é um daqueles seres iluminados: inteligente, sensível e divertido. Nossas cartas e mensagens trocadas conferem à amizade aquele sentido arendtiano, pois que criam um mundo comum ao mesmo tempo que criam e marcam as diferenças; não creio que seria a mesma pessoa ou a mesma pesquisadora sem o convívio com Mauricio.

Monika Dowbor, Martina Rillo Otero, Mércia Silva...Essas três mulheres são da maior importância em minha vida. Juntas, iniciando nossa carreira profissional, debatendo-nos com nossas próprias indefinições e imaturidades, aprendemos (e continuamos aprendendo) a virar "gente grande". Ao mesmo tempo, cada uma delas, com suas especificidades, me ensina sobre a vida e não há palavras suficientes para agradecer por tudo que representam;

A José, Suely e Fátima e também a todas as pessoas entrevistadas, que com boa vontade cederam seu tempo para minhas perguntas curiosas e várias. Sem eles, esse trabalho não poderia ter sido feito;

Com minha mãe, aprendi não apenas o gosto pela pesquisa, mas principalmente aprendi que é possível conciliar todos os papéis (mãe, esposa, pesquisadora). Sua força e integridade me foram dadas como herança, mas a experiência do mestrado me fez melhor compreender as dimensões de sua sabedoria. Padilha, meu padrasto, certamente tem um importante papel em minha trajetória. Desde os tempos do colegial, ele sempre ponderou o peso das escolhas e me ofereceu um generoso espelho no que se refere à minha vontade e capacidade de pesquisar. A ambos, e por ambos, é preciso agradecer.

À Heloísa H. T. de Souza Martins, minha orientadora, também as palavras são insuficientes para agradecer: foi ela, ao "brigar" comigo quando me afastei 
da sociologia, quem me abriu a possibilidade de trilhar o caminho de volta. Leitora cuidadosa, seu respeito pelas minhas escolhas teóricas me deram força e confiança para pensar os problemas sociológicos que me interpelam com tranqüilidade e paciência. Durante esse tempo de convívio, descobri em Heloísa, além de uma orientadora rigorosa, uma companheira delicada e sensível, além de uma mulher surpreendente.

É necessário também agradecer à Bia, que forneceu uma excelente trilha sonora para os longos períodos em frente ao computador, e à Júlia, que mesmo com as advertências do pai, vinha falar comigo enquanto eu trabalhava, perguntando coisas, comentando outras. Ambas, simplesmente por existirem na minha vida, foram lembranças constantes de que havia mais a ser feito do que essa dissertação e, assim, conseguiram a proeza de me ajudar a não perder o pé do chão, a não me exigir demais, aceitando meus próprios limites.

E já que é de limites que estou falando, é preciso falar daquele que me ajuda a transbordá-los. Presença constante, paciência infinita, Edu está ao meu lado para me animar, sacudir, brigar, acolher... A cada momento me ensinando a inconformação, plantando em mim a certeza de que a vida sempre pode ser outra coisa, muito melhor do que aquilo com que a gente se acostuma. Por tudo isso, a ele esse trabalho é dedicado. 


\section{RESUMO}

Esta dissertação tem como tema o "desemprego oculto pelo desalento", procurando, a partir da análise das histórias de trabalho de pessoas que experimentaram a situação de desemprego por desalento, refletir sobre questões ligadas à cultura do trabalho, à cultura do emprego e ao enraizamento. $\mathrm{O}$ trabalho tem como ponto de partida uma breve reflexão sobre as diferentes maneiras de medir o desemprego e segue apresentando e analisando sete trajetórias de trabalho - um homem adulto, duas mulheres adultas e quatro jovens. A análise das trajetórias permite recolher vários elementos que iluminam os valores e as práticas associadas às culturas do trabalho e do emprego, bem como ensinam sobre os limites e as possibilidades de reinvenção das relações com o trabalho quando se tem como referência a vida cotidiana dos indivíduos. Finalmente, conclui-se que o desemprego por desalento pode estar significando sociologicamente a dificuldade experimentada pelos indivíduos para interpretar, na esfera privada, o significado e o sentido das rápidas mudanças que têm lugar no mundo do trabalho.

\section{Abstract}

This dissertation deals with the universe of the "discouraged unemployed", reflecting on the issue of a "culture of work", a "culture of employment" and the question of embededness. The exposition begins with a brief consideration about the different ways of measuring the phenomenon of unemployment and follows on introducing seven histories of work - an adult male, two adult female and four young people. The examination of these histories allows us to collect several elements which serve to illuminate the values and practices that are related to work and employment cultures. Also, they can instruct us about the limits and the possibilities that are given at the present time for us to reinvent the terms with regard to work, having as reference individual's everyday life. At last, we come to the conclusion that "discouraged unemployed" can mean, in sociological terms, the uneasy 
experience of understanding - within the private sphere - the sense of all those fast changes that are happening on labor's world.

Palavras-chave: sociologia do trabalho, desemprego por desalento, cultura do emprego, cultura do trabalho, enraizamento

Key-words: sociology of labor, discouraged unemployed, culture of work, culture of employment, embededness 
"Tendo pois o Senhor Deus formado da terra todos os animais dos campos, e todas as aves dos céus, levou-os ao homem, para ver como ele os havia de chamar; e todo o nome que o homem pôs aos animais vivos, esse é o seu verdadeiro nome".

(Gênesis, 2:19)

Eu deveria cantar.

Rolar de rir ou chorar, eu deveria, mas tinha desaprendido essas coisas. Talvez então pudesse acender uma vela, correr até a Igreja da Consolação, rezar um Pai Nosso, uma Ave Maria e uma Glória ao Pai, tudo que eu lembrava, depois enfiar algum trocado, se tivesse, e nos últimos meses nunca, na caixa de metal 'Para as Almas do Purgatório". Agradecer, pedir luz, como nos tempos que tinha fé. (...)

Acontecera um milagre. Um milagre à toa, mas básico para quem, como eu, não tinha pais ricos, dinheiro aplicado, imóveis nem herança e apenas tentava viver sozinho numa cidade infernal como aquela que trepidava lá fora, além da janela ainda fechada do apartamento. (...).

Já chega, disse para mim mesmo, parado nu no meio na penumbra gosmenta do meio-dia. Pense nesse milagre, homem. Singelo, quase insignificante na sua simplicidade, o pequeno milagre capaz de trazer alguma paz àquela série de solavancos sem rumo nem ritmo que eu, com certa complacência e nenhuma originalidade, estava habituado a chamar de minha vida, tinha um nome. Chamava-se - um emprego.

Caio Fernando Abreu, Onde Andará Dulce Veiga? 


\section{INTRODUÇÃO}

É sempre uma tarefa complexa tentar localizar o "momento-quando" um conjunto de questões e inquietações dispersas se transforma em um problema. No intuito de não perder de vista aquelas que seriam, na formulação precisa da Prof. Leny Sato, minhas regiões imantadas, em torno das quais se articulam os diversos aspectos que apareceram durante o trabalho de pesquisa, diversas vezes me propus essa questão: quando essa curiosidade em pensar as mudanças que têm lugar nos mundos do trabalho começou? Quando a curiosidade se transformou em problema sociológico, construído em torno da categoria desemprego oculto pelo desalento e transpassado pelas noções de enraizamento, cultura do emprego e cultura do trabalho? As imagens que me acorriam durantes esse exercício de interpelação estavam sempre relacionadas ao início de minha atividade profissional.

No início de 2000, com uma equipe de sete sociólogos e uma psicóloga todos formandos ou recém formados - e sob coordenação de uma pedagoga, desenvolvemos durante cinco meses um trabalho de educação cooperativista, com cooperados de uma cooperativa de trabalho.

As contradições e os conflitos vividos ao lado dos cooperados ${ }^{1}$, bem como as dificuldades de sobrevivência de sua identidade de trabalhadores enunciadas por eles a todo o tempo - foram fundamentais para plantar em mim a inquietação sobre a importância simbólica da figura contratual "emprego". Impressionava como a categoria "emprego" operava a crítica que os cooperados faziam à sua situação presente - a falta de carteira assinada aparecia constantemente entre as queixas, sempre associada ao sentimento de terem perdido a legitimidade para acessar o mundo dos direitos ${ }^{2}$. Eles traziam diversos exemplos de como, após a demissão e a adesão à cooperativa,

\footnotetext{
${ }^{1}$ A cooperativa em questão era prestadora de serviços de limpeza e tinha sido constituída - com o apoio do sindicato - a partir da demissão de todos os funcionários, recontratados sob a figura jurídica da cooperativa.

2 Para uma descrição do processo de formação e a análise dos diversos momentos e conteúdos trazidos pelos cooperados, ver Jardim, Otero, Silva \& Dowbor (2004)
} 
encontravam mais dificuldades para ter acesso ao sistema de saúde ou como haviam deixado de conseguir fazer compras à prestação; enfim, suas falas colocavam no centro da discussão a percepção dos efeitos da desigualdade que caracteriza nossa experiência do público, fazendo-o por meio da comparação de sua situação atual com o modo mais legitimo de acessar o mundo dos direitos que eles conheciam: o emprego ${ }^{3}$.

Nosso trabalho (conforme nos houvera sido demandado pela direção da cooperativa) era o de conduzir um processo de educação cooperativista. Assim, durante um longo tempo (três dos cinco meses) trabalhamos com eles os princípios cooperativistas. A segunda fase do curso consistiu em promover encontros entre os funcionários e membros da direção da cooperativa e os cooperados, no espaço de seu local de trabalho. Qual não foi a nossa surpresa ao perceber que, ao final do processo, em suas colocações, os cooperados passaram a utilizar os princípios cooperativistas como medida para definir o que era ou não justo. Como se pode entender esse deslocamento?

Acredito que seja possível dizer que o "emprego" tinha para esses cooperados - trabalhadores que até então, muito provavelmente, transitavam entre o mercado formal e o informal - o sentido de nomear um conjunto de direitos associados à carteira registrada. Assim, mesmo que o emprego não fosse uma realidade constante na vida destes cooperados ou de suas famílias, ele aparecia em seus discursos como um instrumento para o reconhecimento daquilo que é desejado e justo, um instrumento de compreensão do presente e das próprias possibilidades ${ }^{4}$. Assim, diante de uma nova situação, como a

\footnotetext{
3 Para uma discussão sobre a nossa "cidadania regulada" (conforme a expressão de Wanderley Guilherme dos Santos), ver Telles, 2001, especialmente capítulo 2, "Os sentidos da destituição".

${ }^{4}$ A referência ao emprego e sua valorização como o tipo de relação de trabalho desejada não é prerrogativa destes cooperados. Como nota José de Souza Martins, "O emprego passou a ser uma aspiração e uma necessidade por tudo isso, por tudo que significa e propicia. Por isso, justamente, nem toda ocupação é um emprego. O sujeito pode estar ocupado, precária ou temporariamente ocupado com um trabalho ocasional. Não por acaso, muitas pessoas nessa situação se consideram pessoas à procura de trabalho. Subjetivamente, têm consciência de sua inserção precária, incerta e instável nas relações sociais, porque a ocupação temporária não engendra uma rede de relacionamentos relativamente estáveis. Ela é antes de tudo expressão de exclusão e não de pertencimento. Não só porque são ocupações não valorizadas socialmente, mas porque não são reconhecidas como emprego", Martins, 1998:4). A diferença entre a categorização social e a identidade subjetiva em relação à situação ocupacional será discutida no Capítulo 1.
} 
passagem para o trabalho cooperado (e o sentido radical de perda de direitos nesse momento tinha toda a razão de ser), a constante referência ao "emprego" funcionou como crítica e também como expressão da compreensão de que, se a eles estava interrompido o acesso ao emprego, havia que se encontrar outras formas e medidas, que possibilitassem seu reingresso num mundo de direitos cuja ordem eles conhecessem e partilhassem. Dessa maneira, ao se apropriarem dos princípios cooperativistas, encontraram outros nomes aos quais poderiam referir suas relações de trabalho: a questão de fundo, afinal, não era ter ou não um emprego, mas conhecer ou não as relações nos quais estavam inseridos e poderem ser legitimamente reconhecidos por elas 5 .

Localizo nessa experiência com os cooperados o momento inicial de formulação dos problemas que procurei enfrentar nesta pesquisa de mestrado porque ali começou a se formular para mim um problema ao qual chamei de enraizamento ${ }^{6}$. A noção de enraizamento assume aqui o sentido de nomear o conjunto de relações sociais que liga os indivíduos a um mundo comum, impregnado de durabilidade. Ou seja, trata-se das mediações pelas quais se constrói o sentido de pertinência social e, mais do que isso, constrói-se a compreensão do presente e das relações que este estabelece com o passado e o futuro.

A noção de enraizamento aqui utilizada se ancora, em grande medida, na noção arendtiana de mundanidade (Arendt, 1987, 1999a). Por haver se ocupado da política e do que caracteriza o mundo público, esta autora nos sugere que é

\footnotetext{
${ }^{5}$ Esse deslocamento na forma de construir e apresentar suas questões trouxe inúmeros conflitos com a direção da cooperativa. Nós fomos demitidos logo após o final do curso; ficamos sabendo que muitos cooperados foram desligados, (notadamente os que mais tinham se apropriado do espaço do curso) e que, insatisfeitos com os termos do contrato que havia sido renovado, os cooperados haviam entrado em greve contra a direção da cooperativa, provocando uma situação completamente estranha à legislação cooperativista, o que dá notícia das inúmeras contradições vividas por eles.

${ }^{6} \mathrm{O}$ termo enraizamento foi tomado de Simone Weil, que o define como "... talvez a necessidade mais importante e mais desconhecida da alma humana e uma das mais difíceis de definir. O ser humano tem uma raiz por sua participação real, ativa e natural na existência de uma coletividade que conserva vivos certos tesouros do passado e certos pressentimentos do futuro", (Weil, 2001: 43). Ao longo da pesquisa, porém, alguns deslocamentos se fizeram necessários em relação à maneira pela qual Simone Weil constrói a noção de enraizamento. A noção arendtiana de mundanidade, e tudo o que ela implica em relação ao modo de conceber o mundo e a ação, pareceu-me, então, mais fecunda para esclarecer as questões com as quais procurei lidar nesta pesquisa.
} 
ao agirem, isto é, ao conferirem visibilidade às suas opiniões, por meio da fala, que os homens tecem os espaço dos interesses e constroem o mundo. É na ação que os homens têm a possibilidade de humanizar o mundo, nomeando seus tesouros, relacionando passado e presente, criando, enfim, um conjunto de significados que têm maior permanência do que a vida humana7.

O pensamento de Hannah Arendt me parece bastante fecundo para pensar as questões tratadas nesta dissertação porque seu apreço pelo mundo lhe obriga a reconhecer sua instabilidade, daí a necessidade de manutenção de esferas públicas nas quais homens e mulheres se encontrem, falem e encontrem medidas comuns. O enraizamento, neste sentido, pode ser entendido como $a$ pertinência ao mundo produzida pela ação ${ }^{8}$.

Na experiência com os cooperados, como já sublinhei, observei que a idéia de "emprego" operava para nomear a realidade do mundo dos direitos; de alguma forma, mesmo que os cooperados estivessem vivendo um dos aspectos das transformações do mundo do trabalho ${ }^{9}$ de modo privado, eles tinham à sua disposição um conjunto de valores e práticas por meio das quais podiam avaliar suas perdas e dizer suas insatisfações. Dito de outra maneira, ainda que sujeitos a um processo excludente, encontravam na idéia de "emprego" um referencial comum para tornar sua experiência compreensível.

\footnotetext{
7 "A ação e o discurso ocorrem entre os homens, na medida em que a eles são dirigidos, e conservam sua capacidade de revelar o agente mesmo quando o seu conteúdo é exclusivamente 'objetivo', voltado para o mundo das coisas no qual os homens se movem, mundo este que se interpõe entre eles e do qual procedem seus interesses específicos, objetivos e mundanos. Estes interesses constituem, na acepção mais literal da palavra, algo que inter-essa, que está entre as pessoas e que, portanto, as relaciona e interliga. Quase sempre a ação e o discurso se referem a essa mediação, que varia de grupo para grupo, de sorte que a maior parte das palavras e atos, além de revelar o agente que fala e age, refere-se a alguma realidade mundana e objetiva", (Arendt, 1999a: 195; grifos meus). Vale ainda lembrar que a condição humana para que possa haver ação é a pluralidade; esta é a razão principal da crítica que Arendt faz a Marx, pois o trabalho - como atividade - prescinde da diferenciação entre os trabalhadores e, assim, se pode produzir coisas mais permanentes em relação ao labor, ainda assim não poderia produzir mundanidade (Arendt, idem).

8 Esse aspecto é importante porque retira da metáfora do enraizamento qualquer conteúdo conservador em relação às formas, às medidas e às categorias que utilizamos para entender o presente - mesmo dotadas de permanência, elas podem se modificar. Mas para que as novas formas também estejam enraizadas, é preciso que elas sejam produzidas pela ação, ou seja, que sua construção se dê em espaços públicos.

${ }^{9}$ Refiro-me à terceirização dos serviços como estratégia de redução de custos.
} 
Foi esse aspecto do problema que me levou a olhar a categoria desemprego oculto pelo desalento pelo viés daquilo que identifiquei como valores ligados a uma cultura do emprego e a uma cultura do trabalho. Num contexto de rápidas mudanças, que confronta os indivíduos a se adaptarem ou a novas formas de emprego ou a novas formas de desemprego, quais significados a desistência de procurar emprego poderia assumir? De início, eu tinha a impressão de que o desalento pudesse dar notícia dos processos de desenraizamento que estão em curso, na medida em que nem as referências antigas funcionam mais, nem espaços de construção de novas referências parecem existir; o desalento seria, nessa hipótese, um sintoma invisível da privação/privatização que permeia os movimentos de transformação recentes no mundo do trabalho ${ }^{10}$.

Pensar em termos de cultura do emprego e cultura do trabalho consistia no esforço de apreender as categorias de pensamento que pareciam organizar o mundo do trabalho antes que as mudanças começassem a acontecer. Não que tais termos fossem estanques ou que circunscrevessem realidades específicas e não-relacionadas, mas, operando juntos (em suas semelhanças e diferenças), produziam alguma compreensão da dinâmica do trabalho e da vida.

Trabalho nessa dissertação, então, com duas grandes regiões imantadas. A primeira diz respeito ao sentido que as mudanças que ocorrem nos mundos do trabalho assumem na vida dos indivíduos que experimentam o desemprego oculto pelo desalento e, em torno dessa região, gravita a discussão sobre cultura do emprego e cultura do trabalho como instrumentos de compreensão do presente. A outra diz respeito ao sentido que a mudança das relações que os indivíduos estabelecem com

\footnotetext{
${ }^{10}$ Como nota Vera Telles, "A assim chamada crise do Estado não é, como se sabe, problema exclusivo da situação brasileira. Associada à mundialização da economia, tal crise está na ordem do dia no cenário contemporâneo. (...) Mas se a referência a ela importa, é porque ao mesmo tempo em que se processam fragmentações e segmentações que desestruturam identidades coletivas tradicionais e criam novas clivagens, há a erosão das referências públicas nas quais sempre se projetaram, para o bem ou para o mal, esperanças de progresso, de igualdade e de justiça. Se não há razões para lamentar o esgotamento de uma versão estatizada de bem-estar, na qual, no correr do século XX, se projetaram - e se reduziram, como enfatiza Habermas - utopias emancipatórias, o problema todo parece estar em uma perda de parâmetros públicos, sem que outros (ainda?) tenham sido construídos, para problematizar e figurar o drama social como questão pertinente às regras da vida em sociedade. E isso complica enormemente a situação atual" (Telles, 2001: 90-91).
} 
o trabalho assume na vida da sociedade, e em torno dessa questão gravita o tema do enraizamento e dos novos espaços de invenção social.

Como se verá ao final do percurso, as escolhas metodológicas que fiz se mostraram bastante adequadas para pensar a diferença entre cultura do emprego e cultura do trabalho, mas talvez tenham tornado difícil apanhar os significados das mudanças para a vida em sociedade, pelo menos no que se refere aos possíveis novos espaços de invenção. O modo de formular a questão do enraizamento, relacionando-a a espaços de encontro e ação nos quais se poderia imaginar alternativas, e a proposição desta questão ao "desemprego oculto pelo desalento" acabou por traçar um quadro no qual a privatização em relação ao mundo ganha a frente da cena. Nos comentários finais, retomarei esta questão mais cuidadosamente.

O Capítulo 1, “O problema da mensuração", trata da construção social da categoria "desemprego" que se constrói, historicamente, como "o outro do emprego", resultando do esforço de distinção entre aqueles que estão ou não integrados na sociedade salarial. Assim, as figuras do "empregado", do “desempregado" e do "inativo" se referem a realidades de inserção/exclusão do mercado de trabalho de modo bastante claro quando aplicadas a mercados de trabalho estruturados em torno da forma de contrato denominada como "emprego".

No Brasil, no entanto, tais figuras nunca chegaram a dar conta de retratar satisfatoriamente as diversas formas de inserção: para além da diversidade regional, a dinâmica da pobreza constituiu formas de inserção impossíveis de serem captadas pelo viés do "emprego". Assim, no esforço de captar as outras figuras presentes no nosso mercado de trabalho, é que surge a Pesquisa de Emprego e Desemprego - PED, concebida e realizada pelo convênio Fundação Sistema Estadual de Análise de Dados - SEADE e Departamento Intersindical de Estatísticas e Estudos Sócio-Econômicos - DIEESE desde 1984. A pesquisa introduz duas novas categorias na discussão, quais sejam, o desemprego oculto pelo trabalho precário e o desemprego oculto pelo desalento. 
Ainda no Capítulo 1, apresento dados da PED para 1989 e 2001, relativos aos diferentes tipos de desemprego - aberto, oculto por trabalho precário e oculto pelo desalento - e à inatividade. A apresentação desses dados tem como objetivo fazer o exercício de pensar as fronteiras da categoria desemprego, destacando aspectos daquilo que a categoria revela e daquilo que ela parece estar deixando de ser suficiente para revelar.

No Capítulo 2, "Procedimentos de Pesquisa", trato do percurso do trabalho de campo, apresentando uma análise mais geral sobre o conjunto de entrevistados, e procuro refletir sobre minha prática de pesquisa, na relação com os entrevistados e no constante reexame dos problemas sociológicos aqui propostos.

Os capítulos seguintes se dedicam à análise mais detida de algumas narrativas de trabalho; ao todo, faço a análise de sete histórias: um homem adulto, duas mulheres e quatro jovens (uma mulher e três homens).

Desde o início, eu tinha uma grande preocupação com a forma de apresentação das histórias de trabalho: temia não conseguir compreender seus significados e acabar apresentando-as como meras ilustrações de uma reflexão feita aprioristicamente e, por outro lado, temia - no esforço de tecer as análises a partir das falas - não chegar a uma análise sociológica suficientemente densa. Os capítulos estão inteiramente centrados nas histórias e nas narrativas e a presença das falas dos entrevistados é considerável. Isso ocorre por duas razões. A primeira é parte, como já dito acima, do esforço de tecer a análise a partir do que a experiência e a consciência dos entrevistados me ensinou. A segunda razão se refere à intenção de dar ao leitor a oportunidade de verificar, ele mesmo, a pertinência das análises aqui expostas, abrindo-lhe, desse modo, espaço para o diálogo.

No Capítulo 3, “Uma vida de trabalho", apresento a análise da trajetória de José. Começo pela apresentação de sua história porque, dentre as histórias analisadas, é aquela cujas características tornam possível a discussão dos aspectos mais "típicos" de trajetórias de trabalho iniciadas em meados dos anos 70. A história de José introduz elementos importantes para a compreensão dos 
significados assumidos pelo trabalho num contexto em que o emprego existia como fato e/ou possibilidade e também para a compreensão dos significados assumidos pela mudança. A trajetória de José, assim, revela muito sobre aquela que seria a figura do desempregado típico - homem, adulto, chefe de domicílio. É em relação a esta figura, como se verá, que a identidade das "formas atípicas" de desemprego se estruturam.

No Capítulo 4, "Mulher é desdobrável?", apresento a análise das trajetórias de Fátima e de Suely. Embora ambas sejam mulheres, suas trajetórias de trabalhos contrastam fortemente, clarificando importantes aspectos a respeito das relações de trabalho que uma e outra experimentam. Ao final deste capítulo, ainda que a partir de três trajetórias heterogêneas entre si, completa-se o quadro de análise das histórias de trabalho dos adultos.

O Capítulo 5, "Por fora dos trilhos: a lida dos primeiros empregos", por sua vez, possui uma estrutura um pouco diferente dos anteriores pois traz a história de quatro jovens - Mário, Lutemberg, Alessandra e Rodolfo -, os quatro que encontrei na situação de desemprego oculto pelo desalento. Pareceu-me que o tipo de narrativa trazida pelos jovens requeria uma exposição diferenciada na medida em que suas falas não se referem a uma experiência passada e sim a seus projetos de futuro. Nesse sentido, são falas que põem em cena os valores dispersos que hoje estão postos em circulação de um modo mais explícito (em relação à fala dos adultos) e mais explícito porque não estão balizados pela efetividade de uma experiência passada. As experiências de desemprego por desalento desses jovens, também heterogêneas entre si, constroem um interessante contraponto em relação ao quadro composto pela análise da experiência dos adultos, possibilitando o levantamento de aspectos centrais para a distinção entre cultura do emprego e cultura do trabalho e despertando novas questões no que se refere aos eixos que apóiam o enraizamento.

Finalmente, os comentários finais visam recuperar os diversos fios que foram sendo puxados ao longo da análise das trajetórias de trabalho, para tecer algumas interpretações relativas aos possíveis significados das transformações 
que estamos a viver. Além disso, aponto alguns (novos) caminhos que seria interessante percorrer, a fim de refinar o conhecimento sobre as culturas do emprego e do trabalho, no sentido de aprender o que o processo de constituição e reprodução de cada uma delas tem a nos ensinar acerca das relações que desejaríamos estabelecer com o trabalho. Assim, embora esteja trabalhando com trajetórias de trabalhadores - e a dinâmica na qual tais trajetórias se inserem trata-se também de conhecer e compreender o presente a fim de apanhar seus limites e possibilidades e ampliar as margens do possível.

Cabe ainda um último comentário sobre as reflexões desenvolvidas nesta dissertação: como o leitor perceberá, as interpretações e questões que formulo não se apóiam apenas nos elementos levantados a partir da pesquisa ou do trabalho de campo. Em diversos momentos, a análise remete a "casos" e "histórias" ouvidas em diferentes espaços - e desde já adianto que os ônibus e os pontos de ônibus são os espaços mais recorrentes, o que me levou a pensar se não seria o caso de fazer uma espécie de "sociologia dos pontos de ônibus". Brincadeiras à parte, o fato é que esses estreitos espaços de sociabilidade e de encontro entre pessoas oriundas de diferentes lugares me permitiram conversar com pessoas ou ouvir histórias/diálogos que contribuíram tanto para minha reflexão quanto as leituras ou as entrevistas. Por isso, não tive pudores em utilizá-las sempre que apontaram caminhos e questões interessantes. 


\section{CAPÍTULO 1 - O PROBLEMA DA MENSURAÇÃO}

“...as estatísticas não refletem a realidade, refletem o olhar da sociedade sobre si mesma" (Jean-Louis Besson)

A problematização sociológica das diferentes formas de mensuração do desemprego, por si só, constituiria um importante tema de pesquisa e não cair na tentação de trazê-la para a frente da discussão durante o desenvolvimento desse trabalho foi uma das dificuldades enfrentadas.

De fato, desde a formulação do projeto de pesquisa, eu reconhecia nas disputas metodológicas em torno da construção dos indicadores do mercado de trabalho um possível (e interessante) eixo a partir do qual poderia refletir sobre as mudanças em curso no mundo do trabalho. Porém, no desenvolvimento da pesquisa, ao perceber que seria impossível pensar sobre uma categoria tão específica quanto o desemprego por desalento sem ter em conta o debate mais amplo sobre a categoria "desemprego" ela mesma11, foi preciso selecionar e reorganizar as questões levantadas no projeto, conferindo a cada problema um lugar subordinado às reflexões que gravitavam em torno daquelas regiões imantadas expostas na introdução.

Este capítulo tem como objetivo expor alguns dados sobre o desemprego e, em especial, sobre o desemprego por desalento. Tal material permite a discussão sobre os limites e as fronteiras da categoria "desemprego", contribuindo para a compreensão do sentido que a adoção das distinções englobadas pelo "desemprego oculto" têm para o entendimento de um mercado de trabalho tão heterogêneo quanto o nosso. A questão do direito ao

\footnotetext{
11 Essa impossibilidade se deve a que, ainda que o debate sobre os limites e fronteiras da categoria "desemprego" seja subjacente às disputas metodológicas, muitas vezes ele acaba obscurecido em meio à ênfase dada aos "efeitos de desconhecimento" provocados pelas escolhas metodológicas de cada uma das pesquisas em funcionamento. Assim, o que a noção de desemprego oculto revela fica em segundo plano, passando à frente da cena as conseqüências políticas que a divulgação da taxa de desemprego total pode ter. Por exemplo, no início de 2003, a polêmica criada pelas declarações do então diretor da Fundação SEADE, José Eli da Veiga, conferiu bastante visibilidade à disputa em torno nas formas de medir. Para uma interessante discussão sobre os efeitos das diferentes formas de medir, ver Besson, 1995.
} 
trabalho, que permeia a discussão, ganha novos contornos a partir da observação daqueles que "ficam fora da conta" a despeito de sua vontade ou necessidade de trabalhar.

Além disso, na medida em que a pesquisa se estruturou em torno da noção de desemprego oculto pelo desalento, procurando iluminar alguns aspectos relativos às razões da interrupção da procura e alguns dos significados que o trabalho e o desemprego assumem para os indivíduos a partir do momento em que deixam de procurar, é importante olhar mais de perto os dados fornecidos pela Pesquisa de Emprego e Desemprego - PED, estabelecendo comparações entre as diferentes situações ocupacionais e apreendendo melhor o universo delimitado pela categoria.

O caminho seguido nesse capítulo é o seguinte: primeiro, levanto alguns aspectos relativos à problematização sociológica da construção da figura do desemprego e, a partir desta, algumas das críticas feitas aos modos de mensurar o fenômeno.

Em seguida, apresento, em linhas gerais, as características das duas principais pesquisas brasileiras do mercado de trabalho: a Pesquisa Mensal de Emprego (Fundação Instituto Brasileiro de Geografia e Estatística - IBGE) e a Pesquisa de Emprego e Desemprego (Convênio Seade/DIEESE). Baseada nos dados da PED e por meio da comparação entre dois momentos distintos do mercado de trabalho brasileiro - 1989 e 2001 - exploro os limites de cada uma das categorias que compõem a taxa de desemprego total, chamando a atenção para os diferentes tipos de desemprego revelados por elas. Finalmente, sintetizo os achados relativos à categoria "desemprego oculto pelo desalento", tecendo algumas hipóteses sobre o perfil do desempregado por desalento.

"A invenção do desemprego" - Na raiz das disputas metodológicas brasileiras está a constatação de que existem muitas diferenças entre o mercado de trabalho de países desenvolvidos, altamente industrializados e que conheceram a generalização do emprego como forma de contrato de trabalho e os países subdesenvolvidos ou em desenvolvimento, com seus mercados de 
trabalho pouco estruturados, e uma imensa diversidade de situações ocupacionais ${ }^{12}$. A partir dessa constatação, faz-se necessário, então, procurar por outras formas de medir, diferentes daquelas em uso até o início dos anos 80, mais adequadas à nossa realidade e, portanto, mais capazes de produzir conhecimento sobre a dinâmica de nosso mercado de trabalho.

Como a literatura que examinarei a seguir deixa claro, não é possível dissociar o conceito de "desemprego" do contexto no qual é formulado. O que significa dizer que, a despeito de se tratar de uma situação social mais ou menos reconhecível em diferentes países, com diferentes condições de desenvolvimento, o desemprego é uma figura que está intimamente relacionada com as relações de trabalho específicas de cada local e, por isso, precisa ser qualificada para que possa realmente elucidar aspectos do problema que procura nomear.

A necessidade de procurar outros elementos para pensar o mercado de trabalho brasileiro, do ponto de vista do esforço de mensuração do fenômeno, manifesta-se quando se estabelece a compreensão de que em países desenvolvidos, nos quais houve a emergência de um mercado de trabalho claramente estruturado em torno de relações assalariadas, é possível definir a situação ocupacional de um indivíduo tendo por instrumentos três categorias empregado, desempregado e inativo - pois, na medida em que existe um mercado formal estruturado, as situações ocupacionais podem ser definidas tomando-o como referência. Ou se está empregado, ou se vive uma situação (transitória) de desemprego ou não se está disponível para o trabalho (inatividade) $^{13}$.

\footnotetext{
12 Segundo Paula Montagner, as características do mercado de trabalho brasileiro são: pouca estruturação, “(...) grande disponibilidade de mão-de-obra e dinamizado por uma estrutura produtiva marcada por grandes diferenças entre as empresas (...)", (Montagner, 2003: 58). Tais características, articuladas a mecanismos de seguridade limitados e pouco extensivos ao conjunto dos trabalhadores, condicionam um mercado de trabalho no qual mais de metade dos trabalhadores não possuem vínculos formais de trabalho, estando ainda submetidos à alta rotatividade, baixos salários e longas jornadas.

${ }^{13}$ Para uma reconstrução da história das estatísticas de trabalho no Brasil e a constituição dos conceitos de emprego e desemprego a partir da comparação com práticas internacionais, ver Hoffman e Brandão, 1996.
} 
Por outro lado, ao mesmo tempo se estabelece também a compreensão de que tais instrumentos, quando aplicados a realidades como a nossa, deixam muita gente "fora da conta": a dificuldade de definir claramente o que é emprego, o que é trabalho e o que é ocupação acaba por interrogar as três categorias acima mencionadas, evidenciando seu caráter de construções sociais e convidando ao esforço para a criação de novos instrumentos, mais adequados à situação do país ${ }^{14}$.

A análise histórica da "invenção" do desemprego esclarece o que foi dito acima: as fronteiras que delimitam as situações de emprego, desemprego e inatividade não estiveram dadas desde sempre. Ao contrário: tratam-se de categorias socialmente constituídas que, portanto, revelam concepções e representações das relações dos homens com o trabalho.

Topalov, tratando da "invenção" do desemprego na Europa, mostra que a constituição de categorias que definem claramente situações ocupacionais se deu concomitantemente ao processo de consolidação das relações de assalariamento (e dele tomou parte). Nesse contexto, o desemprego aparece formulado sempre como "o outro" do emprego, revelando mais uma inserção do que uma privação: a ausência - transitória - de trabalho, aliada à procura por um novo trabalho definia uma identidade de trabalhador, contraposta à inatividade ou à vadiagem.

A noção de desemprego nasce tanto de necessidades práticas (de formulação de políticas públicas, por exemplo) quanto do desejo de compreensão de um novo fenômeno: "Enquanto ferramenta cognitiva, a noção de desemprego é um dos produtos do esforço multiforme de diagnóstico e de prescrição diferenciados sobre as mazelas da cidade grande, empreendido pelas ciências sociais nascentes, elas mesmas indissociavelmente ligadas ao tratamento e à reforma das massas operárias. Ao mesmo tempo, a noção de desemprego é uma

\footnotetext{
${ }_{14}$ No Brasil, os esforços para enfrentar tais problemas resultaram no suplemento à Pesquisa de Condições de Vida - PCV, em 1983 e, a partir do ano seguinte, no desenho e na realização da Pesquisa de Emprego e Desemprego - PED (Seade/DIEESE), uma pesquisa domiciliar mensal produtora de indicadores do mercado de trabalho alternativos aos números oficiais produzidos pelo IBGE.
} 
categoria prática, determinada a informar a ação. Cada categoria de pobres que a análise vai pouco a pouco distinguir, fará jus, de fato, a medidas específicas, executadas por meio de um quadro administrativo e jurídico adaptado ao "problema a ser tratado'" (Topalov, 1994: 16, grifos meus) ${ }^{15}$.

O que é bastante interessante no trabalho de Topalov é que ele faz uma espécie de "genealogia" da categoria desemprego. Sua análise se concentra nos escritos de intelectuais, mas também nos discursos de reformadores, mostrando como a situação econômica (e a recorrência de crises) não é a única responsável pela constituição da categoria. Os problemas criados pelas mudanças econômicas e sociais que desembocam na invenção do assalariamento acabam pondo em questão o funcionamento das instituições sociais (tanto estatais quanto filantrópicas), estimulando-as a repensar seu público-alvo e seus objetivos e, nesse processo, "inventar" o desemprego.

Assim, Topalov mostra que o desemprego aparece como "o outro" da relação assalariada estável, mas também que a categoria é formulada em conseqüência dos esforços empreendidos para a generalização de tais relações. A constituição de uma sociedade assalariada incita a distinções claras entre pobres/incapazes para o trabalho e desempregados, involuntariamente sujeitos à uma transitória privação do emprego, mas ainda assim partícipes de um modo de relação que interessa preservar e generalizar. É por esta razão que ele não fala em descoberta do desemprego, tornado visível em razão de sua amplitude. Ele fala de "invenção" do desemprego, conseqüência da necessidade de distinção entre os pobres e os "verdadeiros" desempregados.

Essa distinção, no entanto, não tem por objetivo apenas classificar as diferentes situações de não trabalho. Entendida como "o outro" do emprego, ela é também reveladora de uma nova concepção de trabalho: "A 'organização do

\footnotetext{
15 "En tant qu' outil cognitif, la notion de chômage est l'un des produits de cet effort multiforme de diagnostic et de prescription différénciés sur le maux de la grande ville, entrepris par les sciences sociales naissantes, elles-mêmes indissolublement liées au traitement et à la réforme des masses ouvrières. La notion de chômage est en même temps une catégorie pratique, destinée à informer l'action. Chaque classe de pauvres que l'analyse va peu à peu distinguer sera en effect justiciable de mesures spécifiques, mises en ouvres dans un cadre administratif et juridique adapte au 'probléme' à traiter". As traduções feitas ao longo da dissertação são de minha responsabilidade.
} 
mercado de trabalho', que Beveridge (reformador inglês do final do século XIX) $e$ seus pares na França e nos Estados Unidos preconizam deve permitir o estabelecimento duradouro de um número crescente de trabalhadores em relações salariais, apesar da instabilidade inerente a uma economia de concorrência. (...) A solução para qual convergem internacionalmente reformadores de diferentes pontos de vista, na virada do século,compreende dois programas: a racionalização das colocações e a seguridade contra o desemprego"16 (Topalov, 1994:19).

Desse modo, a categoria desemprego é construída na intersecção de esforços de compreensão do fenômeno da existência de pessoas que não têm lugar no mercado de trabalho - ou porque não querem ou porque não encontram - e também do esforço institucional por parte de um Estado de BemEstar nascente, que procura estruturar o mercado de trabalho e estabelecer proteções àqueles que dele participam.

Como outros autores (Salais, Baverez \& Reynaud, 1999; Freyssinet, 1984; Castel, 1998), Topalov descreve a estreita relação entre o pacto do assalariamento e o Estado de Bem-Estar.

É por relacionar a consolidação e a generalização das relações assalariadas ao desenvolvimento do Estado de Bem-Estar que Topalov chega a sugerir que os países subdesenvolvidos não teriam desemprego stricto senso, já que a heterogeneidade de situações de trabalho, sem a generalização do emprego e sem a constituição de mecanismos de seguridade social, não permitiria a emergência de tal situação ${ }^{17}$.

16 " $L$ ' "organisation du marche de travail" que Beveridge et ses semblables en France et aux Etats-Unis préconisent doit permettre de stabiliser durablement dans le rapport salarial um nombre croissant de travailleurs, malgré l'instabilité inhérente à une économie de concurrence. (...) La solution vers laquelle convergent internacionalement à partir du tournant du siècle des réformateurs par ailleurs très divers comprend deux volets: la rationalisation du placement et l'assurance contre le chômage".

${ }_{17}$ Tal questão é formulada de maneira ainda mais explícita em Freyssinet: "(Nos países de terceiro mundo) O desemprego em estado puro não deixa de existir, mas ele não se constitui senão em um aspecto secundário; (...), os desempregados, desprovidos de toda proteção e de todos os recursos, não podem se manter duravelmente em tal situação" (Freyssinet, 1984: 10). ["Le chômage à l'état pur n'est pas inexistant, mais il ne constitue qu'un aspect secondaire; (...) les chômeurs, dépourvus de toute protection et de toute ressource, ne peuvent se mantenir durablement dans une telle situation"\}. Tal questionamento está na origem das divergências metodológicas que distinguem a PME e a PED: a inserção da categoria "desemprego oculto" tem por efeito justamente dar visibilidade à precariedade que marca a situação dos desempregados no Brasil. Incapazes de se dedicarem apenas à atividade de procura, as fronteiras operacionalizadas pela combinação dos critérios de 
Tal hipótese deve ser matizada. A análise de Topalov mostra claramente que a categoria "desemprego" não pode ser compreendida fora do contexto no qual é utilizada. Portanto, é certo que a realidade delimitada pela figura do "desemprego" em países de mercado de trabalho similares ao mercado brasileiro não é a mesma que a que se constitui em países de mercado de trabalho mais homogêneo e estruturado. Falar de "desemprego stricto senso", porém, significa negar a idéia mesma de que estamos a tratar de uma categoria socialmente construída. Mais justo seria afirmar que a figura do desemprego, do ponto de vista objetivo e tal como construída em países de mercado de trabalho homogêneo, não diz respeito senão a uma pequena parte dos trabalhadores nos países subdesenvolvidos - não por acaso, aqueles ligados ao mercado formal de trabalho.

Mas mesmo tal afirmação não pode prescindir de observações. Se é possível dizer que o "desemprego stricto senso" toca apenas aqueles que estão numa situação que podemos chamar "desemprego aberto", o fato é que, cada vez mais freqüentemente, deparamo-nos com situações nas quais os indivíduos se reconhecem como "desempregados", ainda que não apresentem todas as características que nos permitiriam classificá-los como tal. Seja por estar presente na pauta social, seja pela necessidade de manter a identificação com o universo e os valores do trabalho, o fato é que a categoria "desemprego" acaba se tornando operacional para a definição de identidades subjetivas, embora cada vez menos opere para a definição de identidades coletivas (cf. Guimarães, 2003)

As mutações do desemprego - É interessante perceber que, mesmo nos países de mercado considerado como homogêneo, as mudanças que têm ocorrido no mercado de trabalho acabaram provocando o esforço por uma melhor compreensão das novas situações. É assim que alguns autores, ao desemprego na população seja subestimada. Voltarei a esse problema adiante. 
tratarem das novas figuras do desemprego - "desemprego de longa duração", "desemprego por desalento" - e das novas figuras do trabalho - "trabalho a tempo parcial", "trabalho sub-remunerado" - acabam por demonstrar as limitações da categoria "desemprego" para o entendimento do que está acontecendo. Tais autores, ainda que tenham como tema diferentes aspectos da questão - a questão da longa duração ou do desemprego entre jovens ou mulheres - acabam chamando a atenção para o problema da necessidade de qualificação do desemprego, pondo em xeque a idéia mesma de que se trata de uma categoria unívoca ${ }^{18}$.

Maruani (2002), por exemplo, num texto muito estimulante, trabalha com o que chama de "fronteiras do desemprego". Questionando os dados relativos ao desemprego que mostram que, na França, este diminuiu nos últimos cinco anos, ela se preocupa em mostrar o que fica de fora nessa conta, por exemplo, os assalariados precários e os trabalhadores pobres ${ }^{19}$, bem como mulheres, jovens e trabalhadores cuja idade os põe no limite entre atividade e aposentadoria.

\footnotetext{
${ }^{18}$ Seguirei, para ilustrar o argumento, o texto de Maruani, mas existem discussões interessantes também em Freyssinet, 1991 e Demaziére, 1995a.

${ }_{19}$ Maruani faz uma distinção entre essas duas situações. A autora procura traçar as diferenças entre o que compreende por "salarié-e-s pauvres" da noção norte-americana de "working poors". O primeiro aspecto levantado se refere ao estabelecimento da linha de pobreza: enquanto os norte-americanos formulam tal linha tendo em conta uma quantidade $x$ necessária à satisfação de necessidades alimentares (portanto, em termos absolutos), a noção francesa estabelece tal linha em relação ao Salário Mínimo de Inserção (portanto, em termos relativos). Outro ponto se refere à presença no mercado de trabalho e, finalmente, ao cálculo do nível de vida familiar. Maruani conclui, então, que os "working poors" se aproximariam mais da idéia de "actifs pauvres", diferenciando, dessa forma, ocupação e assalariamento. Tal aspecto é importante porque ela vai postular pela adoção do critério do assalariamento, uma vez que o objetivo de tais estudos é compreender um tipo de pobreza específica, que está ligada ao trabalho e que, portanto, precisa deixar de fora quem está excluído das relações de trabalho reconhecidas como legítimas (desempregados, trabalhadores precários, etc.): “ ...após haver tentado identificar as diversas formas de desemprego e de inatividade forçada, provocadas pela escassez de emprego, agora se trata de assinalar tudo o que a pressão do desemprego fez impulsionar a pauperização dos assalariados. O objeto não é a pobreza em si, mas a pobreza dos rendimentos do trabalho, aquela que advém da degradação das condições de emprego, aquela que diz respeito aos assalariados (as) e não aos "excluídos(as)" do mercado de trabalho" " (Maruani, 2001: 106; grifos meus). \{“...après avoir tenté d'identifier les diverses formes de chômage et d'inactivité contrainte dues à la penúrie d'emploi, il s'agit maintenant de repérer tout ce que la pression du chômage a impulsé de pauperisation du salariat. L'object n'est pas la pauvreté en soi, mais la pauvreté des revenus du travail, celle qui provient de la dégradation des conditions d'emploi, celle qui touche les salarié-e-s et non les "exclu-e-s" du marché de travail"\}.
} 
Sua preocupação é, claramente, não permitir que a discussão sobre o desemprego esteja descolada do modo de funcionamento do mercado de trabalho - que é o que acontece quando se tomam as estatísticas como um indicador em si mesmas: "A potencial elevação dos empregos atípicos, assim como o desenvolvimento da pobreza laboriosa são os frutos deteriorados do desemprego de massa que experimentamos por mais de vinte anos. Mas quando o número de desempregados diminui, o que acontece com os assalariados precários e com os trabalhadores pobres? Esta é a questão: não será ao preço da pobreza laboriosa e da desestabilização do emprego que conseguimos suavizar o desemprego?"20 (Maruani, 2001: 8).

$\mathrm{Na}$ atenção que dedica às situações de indefinição, Maruani formula uma hipótese interessante, qual seja, a de que, mesmo durante o período de "pleno emprego", a categoria "desemprego" só torna visível um determinado tipo de desemprego - especialmente, o desemprego masculino, de homens em idade ativa e que possuem uma profissão definida e estável. Explicitar essa hipótese é mais do que fazer reconhecer que a categoria "desempregado" se estabelece frente à constituição de uma sociedade assalariada; significa pôr em cena aqueles que sempre tomaram parte nesta mesma sociedade de modo marginal, incompleto e não inteiramente legítimo: aqueles que ela denomina como os "desempregados da sombra". Por isso, a autora formula sua questão a partir da situação dos jovens, dos imigrantes e, notadamente, das mulheres: tratam-se de trabalhadores mais sujeitos ao trânsito pela zona cinzenta do desemprego.

Maruani toma a disputa em torno dos números do desemprego naquilo que têm, realmente, de mais seminal, que é a inserção de diferentes maneiras de definir e classificar o desemprego - a partir de diferentes concepções de trabalho e direito ao trabalho. É nos espaços de indefinição que é possível conhecer melhor a estruturação da sociedade do assalariamento, com suas regras e suas desigualdades.

\footnotetext{
20 "La montée en puissance des emplois atypiques tout comme l'essor de la pauvreté labourieuse ne sont que les fruits avariés du chômage massif que nous avons connu pendant plus de vingt ans. Mais quand le nombre des chômeurs diminue, qu'advient-il des salariés précaires et des travailleurs pauvres? Là est bien la question: n'est-ce pas au prix de la pauvreté laborieuse et de la déstabilisation de l'emploi que l'on a réussi à affaiblir le chômage?".
} 
Tomei o texto de Maruani para apontar as dificuldades crescentes de apreensão dos significados do não-trabalho num momento em que as mudanças no padrão de relações de trabalho embaralham as fronteiras socialmente constituídas. A situação de crise propõe interrogações à categoria "desemprego", interrogações que tornam mais visíveis sua heterogeneidade e põem em cena novas figuras de não-trabalho que - dependendo do ponto de vista adotado - podem ou não ser entendidas como desemprego. Nesse sentido, o que significa persistir no uso do conceito "desemprego" para tentar compreender as novas formas de não-trabalho? Como a análise sobre a “invenção" do desemprego já demonstrou, significa enfatizar a referência ao mundo dos direitos do trabalho, ainda que se trate de um mundo em mudança. Significa, portanto, enfatizar o valor das relações de trabalho mediadas por medidas comuns, politicamente constituídas - seja para reconhecer as medidas que deixam de valer, seja para apontar quais precisam ser reinventadas. É por essa razão que optei em manter essa discussão, ainda que abreviada, sobre a mensuração e os problemas sociológicos que suscita: as diferentes construções da categoria "desemprego" põem em cena modos de compreender o mercado

de trabalho e a relação que os indivíduos tecem com ele. É esse reconhecimento que justifica a adoção do desemprego por desalento como a categoria-eixo a partir da qual pode se articular a discussão que me interessa fazer: a categoria opera uma forma de compreender o trabalho como direito e esta forma me parece importante para iluminar as diferenças entre uma cultura do emprego e uma cultura do trabalho pois - na pesquisa de campo - a identificação ou não dos sujeitos à condição de desemprego pode dar notícia do mundo do trabalho de referência a partir do qual eles se localizam em suas relações sociais.

\section{PME e PED - As formas brasileiras de medir}

As duas maiores pesquisas que fornecem os dados relativos ao mercado de trabalho no Brasil são de tipo domiciliar, uma vez que - devido à falta de 
mecanismos de seguridade - não há dados institucionais suficientemente confiáveis ou abrangentes que pudessem cumprir tal papel21.

Tabela 1: Comparação entre taxas de desemprego total, Região Metropolitana de São Paulo. Média anual (em \%)

\begin{tabular}{|c|c|c|}
\hline Ano & PME & PED \\
\hline 1980 & 7,20 & - \\
\hline 1981 & 7,25 & - \\
\hline 1982 & 5,98 & - \\
\hline 1983 & 6,79 & - \\
\hline 1984 & 6,80 & - \\
\hline 1985 & 5,02 & 12,2 \\
\hline 1986 & 3,34 & 9,6 \\
\hline 1987 & 3,76 & 9,2 \\
\hline 1988 & 4,02 & 9,7 \\
\hline 1989 & 3,44 & 8,7 \\
\hline 1990 & 4,55 & 10,3 \\
\hline 1991 & 5,51 & 11,7 \\
\hline 1992 & 6,5122 & 15,2 \\
\hline 1993 & 5,73 & 14,6 \\
\hline 1994 & 5,41 & 14,2 \\
\hline 1995 & 5,17 & 13,2 \\
\hline 1996 & 6,72 & 15,1 \\
\hline 1997 & 7,15 & 16,0 \\
\hline 1998 & 9,41 & 18,2 \\
\hline 1999 & 8,3 & 19,3 \\
\hline 2000 & 7,45 & 17,6 \\
\hline 2001 & 6,39 & 17,6 \\
\hline 2002 & 8,4123 & 19,0 \\
\hline
\end{tabular}

Fonte: IBGE e Fundação Seade/DIEESE

21 A legislação que estabelece o seguro-desemprego a partir do Fundo de Amparo ao Trabalhador é recente, de 1990 (Lei 7998, de 11 de janeiro de 1990). Antes disso, o único mecanismo de seguridade disponível era o auxílio-desemprego, ligado ao Instituto Nacional do Seguro Social - INSS. Existem restrições para a requisição do seguro, relacionadas à exigência do tempo de permanência em emprego formal - o que exclui mais da metade dos trabalhadores da possibilidade de acesso ao seguro. Para requerê-lo, é preciso ter trabalhado no mínimo 6 meses com registro; também há uma proporcionalidade entre o tempo trabalhado e o número de parcelas recebidas (no mínimo 3 e no máximo 5). Este número pode ser aumentado conforme a disponibilidade de recursos e a avaliação do CODEFAT sobre "a evolução geográfica e setorial das taxas de desemprego no País e o tempo médio de desemprego de grupos específicos de trabalhadores" (Lei 8.900/94).

${ }^{22}$ Nesse ano, houve problemas na divulgação das taxas de junho e julho.

${ }^{23}$ Tomo aqui como referência a taxa oficial, divulgada para o período de referência de 7 dias, ainda que haja dados disponíveis para o período de 30 dias. 
Apenas para que possamos dimensionar as conseqüências para a medição do desemprego segundo se tome por referência uma ou outra pesquisa, observe-se a tabela 1, que traz as médias anuais das taxas de desemprego desde 1980.

A Pesquisa Mensal de Emprego é realizada pela Fundação IBGE e só se tornou uma pesquisa autônoma, com estatuto próprio, em 1980. Antes disso, era aplicada junto com a Pesquisa Nacional de Amostra Domiciliar - PNAD. Atualmente, a PME é aplicada em seis regiões metropolitanas: Recife, Salvador, Belo Horizonte, Rio de Janeiro, São Paulo e Porto Alegre.

Considerando uma amostra de pouco mais 37.000 domicílios (na Região Metropolitana de São Paulo), a PME leva em conta apenas o chamado "desemprego aberto", ou seja, são consideradas desempregadas pessoas em idade ativa que não tenham exercido atividade remunerada e tenham procurado ativamente trabalho, para um período de referência de 30 dias $^{24}$ (ver Quadro I). A População em Idade Ativa - PIA é definida pelas pessoas acima de $10 \operatorname{anos}^{25}$. A População Economicamente Ativa é definida como a parcela da PIA que, durante a entrevista, foi classificada como ocupada ou desocupada.

A PME não sofria mudanças metodológicas desde 1982 e em 2002 passou por um processo de modificações, relacionadas principalmente à diminuição da idade utilizada na divulgação dos dados (de 15 para 10 anos, conforme nota 25); diminuição do número de horas trabalhadas na semana para que se considere alguém ocupado (de 15 para 1 hora); aumento do tempo de referência (de 7

\footnotetext{
24 Desde janeiro de 2002, a PME vinha testando a mudança em relação ao período de referência (que anteriormente era de 7 dias), divulgando dados referentes aos dois períodos. No inicio de 2003, anunciou-se a consolidação da mudança. O período de referência da pesquisa era um dos pontos de discórdia entre as metodologias, na medida em que, se esse tempo for muito curto, a taxa de desemprego, bem como as taxas de ocupação e desocupação, ficam sujeitas a oscilações provocadas não pela dinâmica do mercado de trabalho mas por razões circunstanciais - doença, motivos familiares, etc.

${ }^{25}$ Até o início de 2003, a PME, embora tivesse como critério de definição da PIA o limite de 10 anos, para fins de divulgação da taxa levava-se em conta apenas a população de 15 anos e mais. Tal medida se justificava pela idade então (1980) legalmente definida para o início do trabalho, a partir dos 14 anos. Porém, com as mudanças introduzidas pela nova metodologia, a taxa de desemprego divulgada passou a levar em conta a população de 10 anos e mais, a despeito do Estatuto da Criança e do Adolescente (Lei no 8.069, de 13 de julho de 1990), que estabelece em 16 anos a idade legal para o trabalho. Sobre as mudanças introduzidas, ver "Notas metodológicas - a nova PME", (IBGE, 2003a).
} 
para 30 dias anteriores à realização da entrevista) e inclusão da categoria desalento na taxa de inatividade.

Segundo a nota metodológica divulgada pelo IBGE, "o conceito fundamental da pesquisa continua sendo o de trabalho, que significa a ocupação econômica remunerada em dinheiro, produtos ou outras formas não monetárias e a ocupação econômica não remunerada", (IBGE, 2003).

Os textos publicados pelo IBGE, em diferentes momentos da história da PME, se preocupam bastante com a delimitação conceitual das categorias utilizadas e explicitam muitas vezes que a ênfase da PME está na criação de indicadores para o mercado de trabalho (contrapondo-se assim ao esforço por mensurar mais precisamente o desemprego).

Ainda que os textos metodológicos reconheçam as diferenças existentes entre mercados de trabalho mais estruturados e mercados tais como o brasileiro, eles acabam interrompendo a discussão quando se deparam com a dificuldade de criar novas categorias e novos instrumentos de mensuração dos fenômenos.

Isso se torna explícito num texto como o de Félix, Mello, Castello Branco e Pacheco (1981), que tem por objetivo contribuir para a discussão dos conceitos utilizados pelas pesquisas de emprego e desemprego. Os autores procedem a uma revisão bibliográfica sobre o surgimento e o tratamento dos termos emprego, subemprego e desemprego. Ao fazer isso, apontam para a dificuldade de distinção entre emprego e trabalho - o que tem conseqüências para as outras duas categorias. Segundo eles, as dificuldades se referem aos critérios a partir dos quais se estabelece a categoria; desse modo, a realidade delimitada é diferente conforme se adote como referência as diversas formas de atividade econômica ou se tenha em mente critérios de ordem jurídica ou, ainda, se pense na produtividade do setor no qual a ocupação está alocada.

Tal constatação leva os autores a localizar um "abismo" existente entre as teorias de emprego, subemprego e desemprego e aquilo que os dados revelam; justamente porque a produção dos dados se apóia numa construção conceitual que está longe de ser comumente acordada. É a partir daí que os autores 
analisam alguns estudos que se apropriaram dos dados, então gerados pela PNAD. A análise tem por objetivo evidenciar os problemas de articulação entre teoria e prática provocados pela utilização de categorias que não são claras: " $O$ que se nota na maior parte dos autores é que as categorias utilizadas como instrumentos operacionais constituem-se na maior parte das vezes em meras aproximações das questões teóricas. Por suas próprias definições, tais categorias são em geral muito amplas e algumas vezes ambíguas, exigindo dos autores um esforço em relativizá-las através de adicionamentos de variáveis. Se por um lado isto não resolve o problema da defasagem teoria-dados, por outro, pode sugerir caminhos para um maior aperfeiçoamento das pesquisas estatísticas, particularmente das oficiais", (Félix et alli, 1981: 34-5; grifos meus). É interessante notar que, ao mesmo tempo que reconhecem os limites, os autores apontam para a possibilidade da construção teórica contribuir para a ampliação do referencial conceitual utilizado pelas pesquisas estatísticas.

Se abri aqui um pequeno espaço para a recuperação do tipo de discussão que se trava dentro da instituição pesquisadora - a Fundação IBGE - é porque a maneira de discutir o problema é fundamental para que entendamos as formulações que dão origem aos conceitos a partir dos quais as pesquisas são desenhadas; além disso, elas também influenciam a maneira de dar visibilidade e significado aos dados.

A ênfase que os textos metodológicos da PME dão à noção de trabalho considerando como tal um amplo leque de atividades econômicas - sugere uma maneira de pensar o mercado de trabalho que naturaliza as situações precárias ou informais, subsumindo-as todas na categoria "ocupação". Essa naturalização é um efeito do reconhecimento da dificuldade de, num mercado de trabalho heterogêneo, admitir como ocupação apenas o trabalho formal, desconsiderando as diversas outras formas de inserção (experimentadas por mais de 50\% dos ocupados) e, ao mesmo tempo, distinguir dentre as ocupações não-formais aquelas que, de fato, preservam condições mínimas de relações de trabalho. Em ambas as dificuldades se evidencia a incapacidade que até agora tivemos para construir novas medidas, para além da forma "emprego"; à falta 
dele (tanto de fato como enquanto ferramenta analítica), tudo o mais parece indistinto.

\section{Quadro I - PME: Principais Conceitos}

PEA

- $\quad$ A população ocupada na semana de referência compreende as pessoas que exerceram trabalho, remunerado ou sem remuneração, durante pelo menos uma hora completa na semana de referência ou que tinham trabalho remunerado do qual estavam temporariamente afastadas nessa semana.

- Considerou-se como ocupada temporariamente afastada de trabalho remunerado, a pessoa que não trabalhou durante pelo menos uma hora completa na semana de referência por motivo de férias, greve, suspensão temporária do contrato de trabalho, licença remunerada pelo empregador, más condições do tempo ou outros fatores ocasionais. Assim, também foi considerada a pessoa que, na data de referência, estava afastada: em licença remunerada por instituto de previdência por período não superior a vinte e quatro meses; do próprio empreendimento por motivo de gestação, doença ou acidente, sem ser licenciado por instituto de previdência, por período não superior a três meses; por falta voluntária ou outro motivo, por período não superior a trinta dias.

- A população desocupada na semana de referência compreende as pessoas sem trabalho na semana de referência, mas que estavam disponíveis para assumir um trabalho nessa semana e que tomaram alguma providência efetiva para conseguir trabalho no período de referência de 30 dias, sem terem tido qualquer trabalho ou após terem saído do último trabalho que tiveram nesse período.

\section{INATIVOS}

- A população não economicamente ativa na semana de referência é constituída pelas pessoas em idade ativa que não foram classificadas como ocupadas nem como desocupadas na semana de referência. Dentre os inativos, encontram-se pessoas marginalmente ligadas à PEA, compreendendo as pessoas não economicamente ativas na semana de referência que estiveram na PEA no período de captação de 358 dias e que estavam disponíveis para assumir um trabalho na semana de referência da pesquisa, e as pessoas desalentadas, compreendendo as pessoas marginalmente ligadas à PEA na semana de referência da pesquisa que estavam procurando trabalho ininterruptamente há pelo menos seis meses, tendo desistido por não encontrar qualquer tipo de trabalho, trabalho com remuneração adequada ou trabalho de acordo com as suas qualificações.

Fonte: IBGE, 2002

Finalmente, é preciso chamar a atenção para a mudança metodológica a partir da qual a PME passou a contabilizar a situação de desalento reconhecendo, portanto, que existem situações em que as pessoas deixam de fazer parte da PEA involuntariamente. Porém, tal reconhecimento ocorreu de 
modo restritivo, alocando a categoria dentro da taxa de inatividade. Embora seja um passo importante para a distinção das diversas situações que compreendem o desemprego, continua-se privilegiando o critério de "procura" como operador da categoria, negando-se desse modo à pessoa que deixou de procurar emprego (mesmo desejando encontrar) o estatuto de desempregado e, portanto, sua participação na PEA.

A Pesquisa de Emprego e Desemprego - PED, conduzida pela parceria entre a Fundação Seade e o DIEESE, foi testada durante o ano de 1983, como um suplemento à Pesquisa de Condições de Vida - PCV. A partir de 1984, ela passou a ser realizada e divulgada mensalmente. Inicialmente aplicada apenas na região metropolitana de São Paulo, ela foi se propagando por outras regiões metropolitanas, geralmente por meio de parcerias com fundações públicas, órgãos de governo locais ou sindicatos.

A principal inovação trazida pela PED consiste no esforço para definir e contabilizar o chamado "desemprego oculto", aquelas situações ocupacionais que não costumam ser consideradas como desemprego. Para compor esta taxa, a PED introduziu duas subcategorias: o desemprego oculto pelo trabalho precário e o desemprego oculto pelo desalento ${ }^{26}$.

Quando apresenta seus dados, a PED traz discriminadas as porcentagens que se referem ao desemprego aberto e as que se referem ao desemprego oculto. Essa é uma forma de, ao mesmo tempo em que se procura dar conta da heterogeneidade que caracteriza o país, garantir a comparabilidade internacional dos dados ${ }^{27}$.

\footnotetext{
${ }^{26}$ Para uma discussão sobre as inovações metodológicas da PED, ver Mendonça e Hoffmann, 1999.

${ }^{27}$ Este aspecto ganha renovada importância à medida que as mudanças nos padrões de relações de trabalho vêm borrando progressivamente as fronteiras que permitem a constituição da taxa do "desemprego aberto" mesmo em países que conheceram alto grau de estruturação do mercado de trabalho. $\mathrm{O}$ reconhecimento das fronteiras e da multiplicação de situações inclassificáveis convida ao esforço por pensar os valores que estão em jogo na produção da categoria desemprego e, assim, transgredir a categoria, estendendo-a àquelas situações que, social e politicamente, devem ser reconhecidas como privação do direito ao trabalho. (Maruani, 2002; Maruani \& Reynaud, 1993 e Demazière, 1995b).
} 
A PED define a PIA considerando indivíduos de 10 anos e mais ${ }^{28}$. É na definição da PEA, porém, que as diferenças metodológicas se aprofundam (ver Quadro II): além dos critérios envolvidos para a apreensão do desemprego aberto - realização ou não de trabalho ou procura -, a PED leva em conta outros critérios, a fim de captar as situações heterogêneas e suas conseqüências para os trabalhadores e para a sociedade: "Esta nova maneira de classificação da condição de atividade capta, além do desemprego aberto, também formas ocultas de desemprego, o que possibilita acompanhar não só a evolução de um mercado de trabalho heterogêneo, como torna mais abrangente a aferição dos efeitos sociais do desemprego" (Seade, 1995:17; grifos meus).

Os critérios utilizados pela PED, então, são: "procura efetiva de trabalho; disponibilidade para trabalhar com procura em 12 meses; situação de trabalho; tipo de trabalho exercido e necessidade de mudança de trabalho" (Seade, idem: 18). Trata-se de uma importante diferença em relação à PME, pois põe no centro da discussão a questão do direito ao trabalho, procurando abranger aqueles que estão privados desse direito, seja por não encontrarem reiteradamente trabalho, seja por conseguirem se inserir apenas em trabalhos precários. A PED capta, desse modo, e tendo em consideração a dinâmica própria do mercado de trabalho brasileiro, algumas das situações de desemprego que poderiam ser consideradas como atípicas em contextos nos quais o desemprego aberto é a regra.

Ambas as pesquisas buscam conhecer melhor a realidade do mercado de trabalho brasileiro e é nas divergências metodológicas entre elas que é possível levantar algumas questões interessantes, que ajudam a identificar onde estão nossas zonas cinzentas - os espaços do mercado de trabalho cujas características e dinâmica ainda temos dificuldade em distinguir. Mas é neste ponto, no entanto, que é preciso reconhecer a distinção entre os objetivos e métodos das pesquisas aqui brevemente descritas e as deste trabalho.

\footnotetext{
28 "A consideração de indivíduos de 10 a 14 anos como integrantes da PIA decorre da própria realidade social do país, no qual parcelas significativas de crianças nesta faixa etária são levadas a trabalhar", (Seade, 1995: 16). Sobre essa diferença em relação à PME, ver nota 25.
} 


\section{Quadro II- Combinação dos parâmetros para definir a condição de} atividade da PIA

\begin{tabular}{|c|c|c|c|c|c|}
\hline \multirow[b]{2}{*}{$\begin{array}{l}\text { Condição de } \\
\text { atividade }\end{array}$} & \multicolumn{5}{|c|}{ Parâmetros } \\
\hline & $\begin{array}{l}\text { Procura } \\
\text { efetiva de } \\
\text { trabalho }\end{array}$ & $\begin{array}{l}\text { Disponibilidade } \\
\text { atual para } \\
\text { trabalhar (com } \\
\text { procura em } 12 \\
\text { meses). }\end{array}$ & $\begin{array}{c}\text { Situação de } \\
\text { trabalho }\end{array}$ & $\begin{array}{l}\text { Tipos de } \\
\text { trabalho } \\
\text { exercido }\end{array}$ & $\begin{array}{l}\text { Necessidade } \\
\text { de mudança } \\
\text { de trabalho }\end{array}$ \\
\hline \multicolumn{6}{|l|}{ PEA } \\
\hline $\begin{array}{l}\text { Desemprego } \\
\text { aberto }\end{array}$ & Sim & --- & Não & --- & --- \\
\hline $\begin{array}{l}\text { Desemprego } \\
\text { oculto } \\
\text { trabalho }\end{array}$ & Sim & --- & Sim & Irregular & Sim \\
\hline $\begin{array}{l}\text { precário } \\
\text { Desemprego } \\
\text { oculto } \\
\text { trabalho } \\
\text { nrecário }\end{array}$ & não & Sim & Sim & Irregular & Sim \\
\hline $\begin{array}{l}\text { precário } \\
\text { Desemprego } \\
\text { oculto pelo } \\
\text { desalento }\end{array}$ & não & Sim & Não & --- & --- \\
\hline Ocupado & $\operatorname{sim}$ & --- & Sim & Irregular & Não \\
\hline Ocupado & $\operatorname{sim}$ & --- & Sim & Regular & sim/não \\
\hline Ocupado & não & Sim & Sim & Irregular & Não \\
\hline Ocupado & não & Sim & Sim & Regular & $\operatorname{sim} /$ não \\
\hline Ocupado & não & Não & Sim & --- & --- \\
\hline Ocupado & não & Não & Sim & Irregular & --- \\
\hline INATIVOS & & & & & \\
\hline $\begin{array}{l}\text { Inativo com } \\
\text { trabalho } \\
\text { excepcional } \\
\text { Inativo sem } \\
\text { trabalho }\end{array}$ & não & Não & Não & excepcional & --- \\
\hline
\end{tabular}

Fonte: PED - Operacionalização dos Conceitos (Seade, 1995:19).

Para fugir à tentação, aludida no início do capítulo, de tomar as formas de mensuração como o principal objeto desta pesquisa, é preciso, sem dúvida, reconhecer ambas as pesquisas existentes, apontar suas diferenças e levantar alguns aspectos dos problemas que enfrentam tendo como objetivo ponderar a importância e os significados dos dados estatísticos, sublinhando seu caráter de 
construções sociais. Mas, infelizmente, não é possível aprofundar tais questões, por mais importantes que sejam.

Desse modo, a partir de agora tratarei de apenas utilizar os dados da PED, procurando tornar mais clara a categoria "desemprego oculto pelo desalento" e qual parcela de trabalhadores ela faz "entrar na conta" do desemprego.

A categoria "desemprego por desalento" - A categoria "desemprego oculto pelo desalento" é uma categoria introduzida no Brasil pela PED. Como exposto acima, o que estava em questão quando do desenho da pesquisa era a construção de categorias que fossem adequadas à mensuração de situações de trabalho e desemprego que não eram captadas pelos critérios que operacionalizam a taxa de "desemprego aberto". Tal objetivo está mais explícito no texto de explicação sobre os conceitos e a metodologia da PED," (a PED tem por propósito) captar e divulgar informações segundo uma metodologia que permita às instituições produtoras expressar situações típicas de um mercado de trabalho heterogêneo, no qual os limites entre as condições de ocupado, desempregado e inativo são muito tênues", (Seade, 1995:3)".

O desemprego oculto por desalento se refere às pessoas que estão sem trabalho há mais de 12 meses e que, por algum motivo, não procuraram emprego nos últimos 30 dias, embora o tenham feito, ativamente durante pelo menos 15 dias, em algum momento dos últimos 12 meses (Seade, 1995). Além disso, a pessoa deve ter vontade e disponibilidade para o trabalho.

Ao incluir a situação de pessoas que não apresentam o comportamento de procura de trabalho, ou que se encontram sub-ocupadas, a PED assume a dificuldade de estabelecer as fronteiras entre emprego, desemprego e inatividade, mas o faz em outra direção (em relação à PME): no centro de sua construção está a preocupação em identificar a precariedade e as dificuldades em relação ao trabalho existentes num mercado de trabalho pouco estruturado como o nosso 29 .

\footnotetext{
${ }^{29}$ Sobre os critérios que operacionalizam a identificação da situação de desemprego, Freyssinet nota que se trata da combinação de um critério de situação - ter ou não um trabalho - e outro
} 
A pergunta que cabe fazer é: quem são as pessoas que, por meio da categoria "desemprego oculto pelo desalento", passam a ser contabilizadas como desempregadas?

\section{Luz e sombra: o que revelam as diferentes taxas de desemprego ${ }^{30}$ - Desde} já, é importante chamar a atenção para o seguinte aspecto: o interesse, ao comparar as situações captadas pelos diferentes tipos de desemprego - tal como definidos pela PED - é refletir sobre as representações que informam aquilo que cada um deles é capaz de revelar.

Para isso, optei por comparar as diferentes taxas de desemprego no que se refere a atributos pessoais e ao tempo de procura por trabalho. Desse modo, acredito conseguir apontar alguns aspectos do problema, a partir do reconhecimento do que cada uma das taxas é capaz de revelar acerca do "halo do desemprego", as regiões fronteiriças que aparecem (cada vez mais) borradas em situações de mercado de trabalho pouco estruturado em torno do “emprego".

É importante notar que, devido ao recorte operado por essa pesquisa, trabalho aqui com os dados relativos à Grande São Paulo, cujas características do mercado de trabalho diferem bastante em relação às de outras regiões do país. Trata-se de ressalva importante porque significa limitar a análise aqui exposta ao mercado de trabalho da Grande São Paulo ou, no máximo, a mercados regionais de trabalho cujas características sejam similares, não pretendendo, portanto, de forma alguma, iluminar aspectos referentes ao

de comportamento - estar à procura, realizando esforços para conseguir um novo emprego. Essa heterogeneidade estaria na origem da fragilidade do conceito, que leva em conta menos a situação do mercado de trabalho e as possibilidades de realização do direito ao trabalho e mais o julgamento moral que está na origem da distinção entre trabalhadores e incapazes para o trabalho/ vadios (Freyssinet, 1984).

30 Os dados apresentados nesta sub-seção são os da Pesquisa de Emprego e Desemprego Fundação Seade/DIEESE, na Grande São Paulo. As tabulações que aparecem aqui, com o objetivo de estabelecer comparações entre as diferentes taxas de desemprego no que se refere a atributos pessoas e tempo de procura, foram elaboradas por mim a partir dos microdados da PED, material disponibilizado em disquetes ou CD pela Fundação Seade. Utilizei os dados de 1985 a 2001. Em tempo, agradeço ao Prof. Álvaro Comin, que se pôs à disposição para quaisquer que fossem as dificuldades no tratamento dos dados da PED. 
mercado de trabalho brasileiro em geral, cuja heterogeneidade não se refere apenas às diversas situaç̃ôes ocupacionais mas também às diversas configurações regionais ${ }^{31}$.

O que desde início chama a atenção no Gráfico 1 é a íntima relação que parecem guardar os três tipos de desemprego: o movimento de cada um é bastante similar, havendo, a partir dos anos 90, um crescimento constante comum a todos eles. Embora o desemprego aberto seja o que apresenta os picos mais acentuados, o que poderia ser explicado pelo fato de que as pessoas têm sensibilidade aos movimentos do mercado de trabalho (procurando mais quando percebem possibilidades de encontrar e deixando de procurar quando a situação fica mais difícil), o desemprego oculto pelo trabalho precário e o desemprego por desalento seguem de perto seus movimentos.

Em teoria, seria possível pensar que haveria uma correlação inversa entre desemprego aberto e desemprego por trabalho precário: quando o mercado formal se apresenta fechado, a necessidade de geração de renda "empurraria" as pessoas para o setor informal ${ }^{32}$. No entanto, não é isso o que ocorre, o que nos leva a pensar sobre a dinâmica desse setor informal, que não se apresenta de modo algum como um setor pouco estruturado, permeável às atividades de "viração", mas sim progressivamente imbricado ao setor formal e às suas oscilações.

\footnotetext{
${ }^{31}$ Para a apresentação de alguns dados importantes sobre as diferenças regionais, ver DIEESE (2001). Para uma discussão dos dados relativos às Regiões Metropolitanas e os desafios que propõe, ver Montagner, 2003.

32 Isto se aceitamos a idéia de que a desorganização do mercado de trabalho, ainda que torne os postos formais de trabalho instáveis, também atua criando oportunidades de inserção trabalhos precários e atividades de auto-ocupação utilizadas como estratégia para a sobrevivência durante os períodos de desemprego.
} 
Gráfico 1 - Evolução do desemprego, por tipo (em \%)

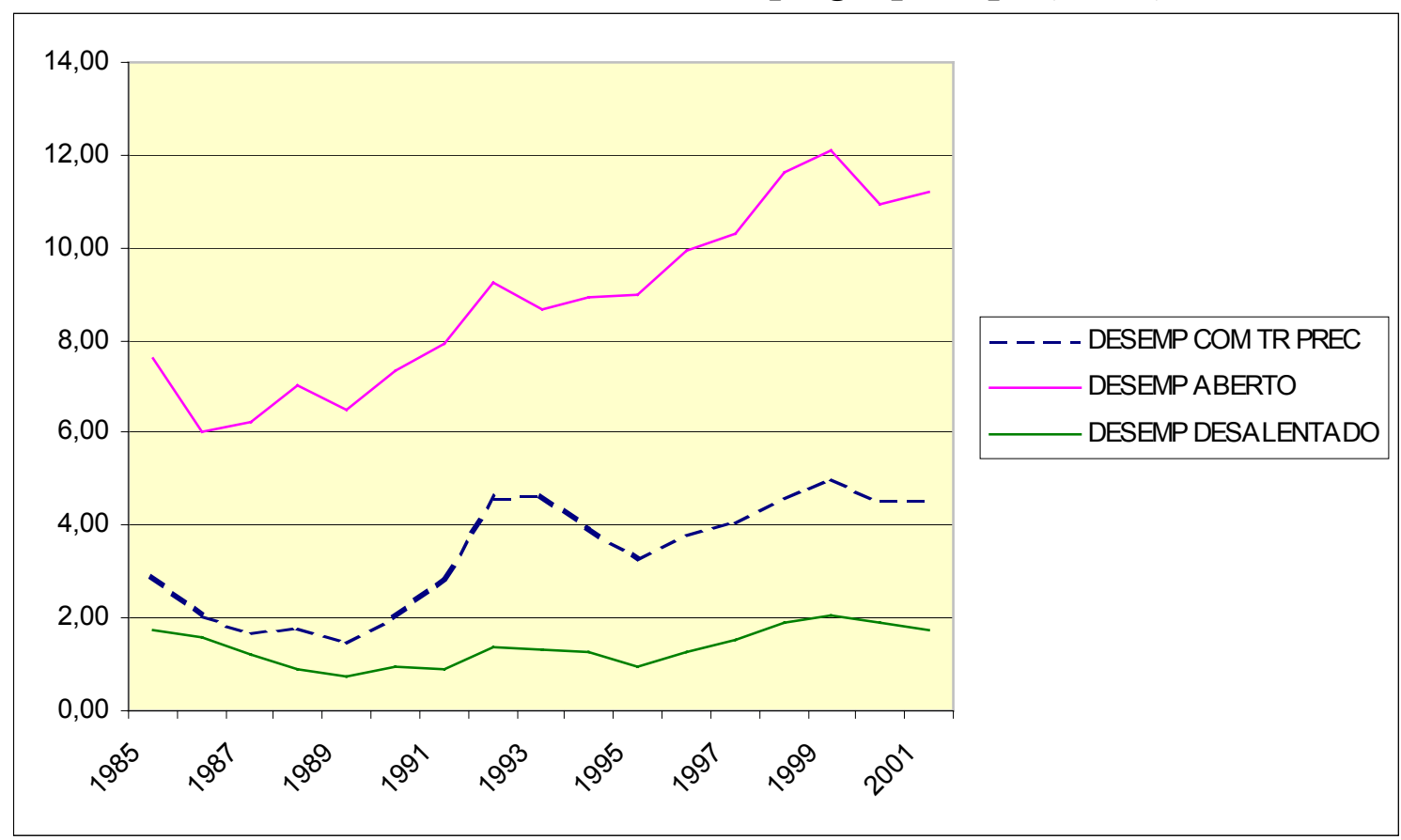

Dados:PED (Seade/DIEESE), Tabulação própria

O Gráfico 2, que mostra o ritmo de crescimento dos três tipos de desemprego, confirma esta interpretação. Enquanto o desemprego aberto cresce continuamente, aumentando em 50\% entre 1985 e 2001, o desemprego oculto pelo trabalho precário é o que aumenta de modo mais acelerado, quase dobrando no período de 15 anos. A relação próxima entre o movimento do desemprego aberto e do desemprego oculto pelo trabalho precário fica ainda mais evidente nesse gráfico.

O desemprego oculto pelo desalento segue um ritmo de crescimento mais ou menos contínuo, decrescendo entre 1985 e 1990, a partir de então aumentando constantemente e apresentando um rápido crescimento entre 1995 e 2000. 


\section{Gráfico 2 - Índice de crescimento das taxas de desemprego, por tipo} $(\mathbf{1 9 8 5}=\mathbf{1 0 0 )}$

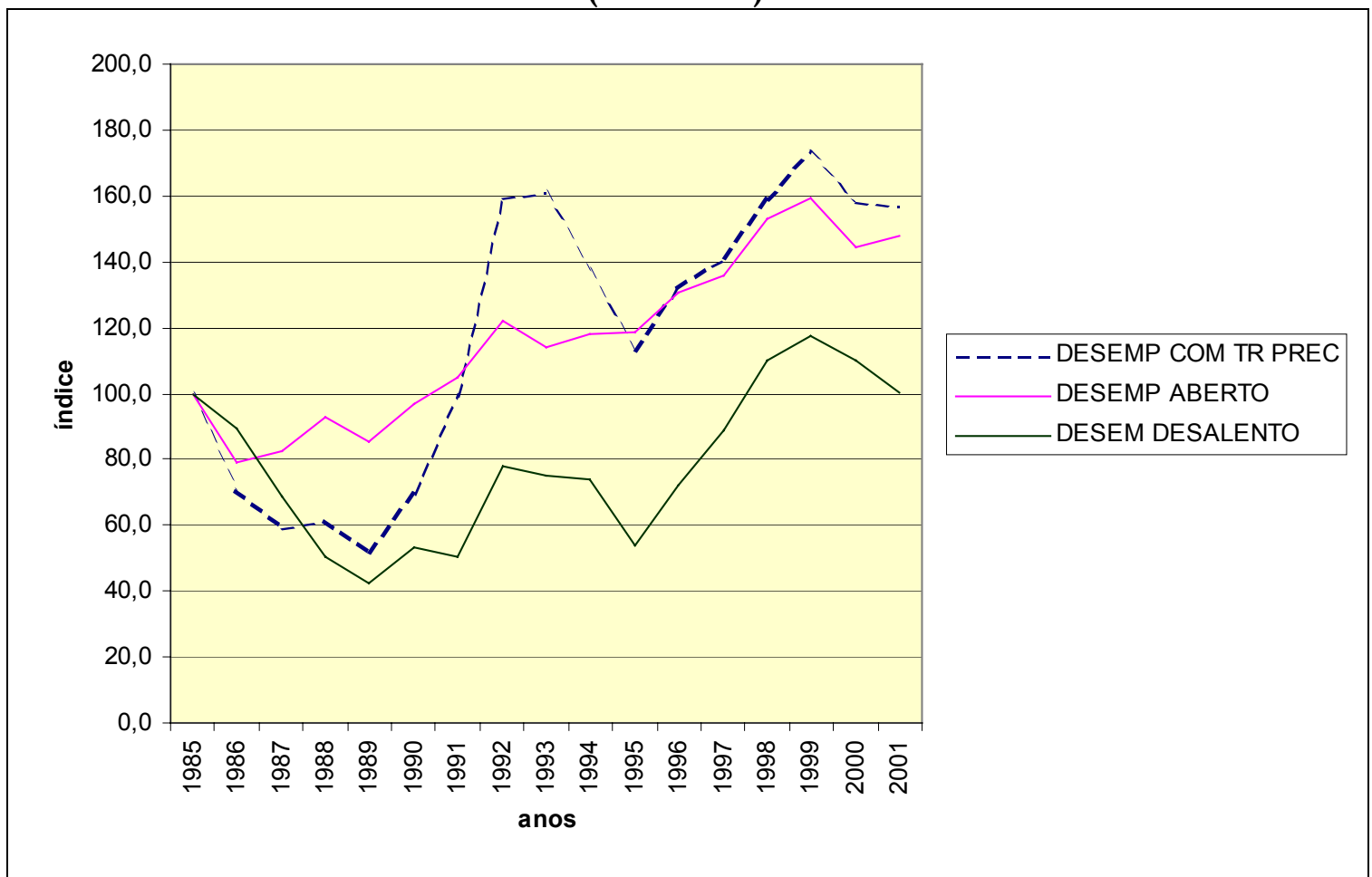

Fonte: PED (Seade/DIEESE). Tabulação própria ${ }^{33}$

Em relação aos atributos pessoais, optei por trabalhar com os dados de 1989 e 2001. Como o objetivo é analisar as mudanças que ocorrem durante o processo de transformação de nosso mercado de trabalho, tomei o ano de 1989 como referência, porque marca o início da adoção de um conjunto de medidas que modificaram as relações de trabalho. A despeito da crise que caracterizou os anos 80 - a "década perdida" -, o problema do desemprego era, até 1989, figurado como sintoma da estagnação, prescrevendo-se ações de estímulo ao crescimento como a solução mais certa. Era, portanto, um problema de geração de novos postos de trabalho ${ }^{34}$.

33 A sugestão da apresentação dos dados relativos ao índice de crescimento das taxas, complementando a apresentação da evolução das taxas, me foi dada pela Prof. Nadya Guimarães, por ocasião do exame de qualificação.

34 Tome-se, como exemplo, dados que mostram a evolução da taxa de formalização:"Considerando apenas os ocupados nos setores privados da economia, o assalariamento formal que respondia por 60,3\% de todas as ocupações em 1989" - quase 60 anos após a Consolidação das Leis do Trabalho - "recua quase 15 pontos percentuais, representando 47,5\% das ocupações em 2001, com a correspondente expansão das ocupações por conta própria e do assalariamento informal" (Comin, 2003:50). Ou seja, mesmo no ponto máximo alcançado pela generalização da formalidade, $40 \%$ da população economicamente ativa não participava do mercado formal. 
As eleições de 1989, que elegeram Fernando Collor de Mello, operaram alguns deslocamentos em relação aos diagnósticos formulados anteriormente. Intricou-se o problema do desemprego à legislação trabalhista em vigor, passando-se a prescrever ações de "flexibilização" como o modo privilegiado de geração de novos empregos. A partir de 1990, com a tomada de posse de Fernando Collor de Mello, inicia-se um ciclo liberalizante.

O ano de 1989 marcou, assim, o ponto máximo da regulação do mercado de trabalho brasileiro referenciado pela CLT. Além disso, como podemos notar no Gráfico 1, ele também marca o término do período de declínio da taxa de desemprego, que a partir de 1990, cresce constantemente.

Quando a análise se referia aos atributos pessoais, tais como sexo, escolaridade e idade, utilizei também os dados relativos aos inativos, já que o objetivo era o de pensar as "fronteiras do desemprego" e, como se verá a seguir, para alguns desses atributos, a linha que separa desempregados de inativos é bastante tênue.

Para organizar a discussão, as tabelas apresentadas trazem dados para os dois anos escolhidos como referência. Vale lembrar que não se trata aqui de realizar uma análise profunda dos dados, nem de esgotar as hipóteses que poderiam explicá-los. O objetivo da apresentação desses dados é o de tatear os limites da cada uma das categorias, principalmente daquela que é objeto a pesquisa, o desemprego por desalento.

Observando a Tabela 2, confirma-se o quadro desenhado pelo Gráfico 1, ou seja, houve um grande aumento das taxas de desemprego, de modo geral. A primeira coisa que chama a atenção, ainda sem diferenciação por tipo de desemprego, é o aumento do tempo de procura: enquanto em 1989 a procura por até 3 meses concentrava a maior parte das pessoas desempregadas, em 2001 a procura de 6 a 12 meses é que passa a concentrar tais pessoas. 
Tabela 2: Tempo de procura, por tipo de desemprego - 1989 e 2001 (em \%)

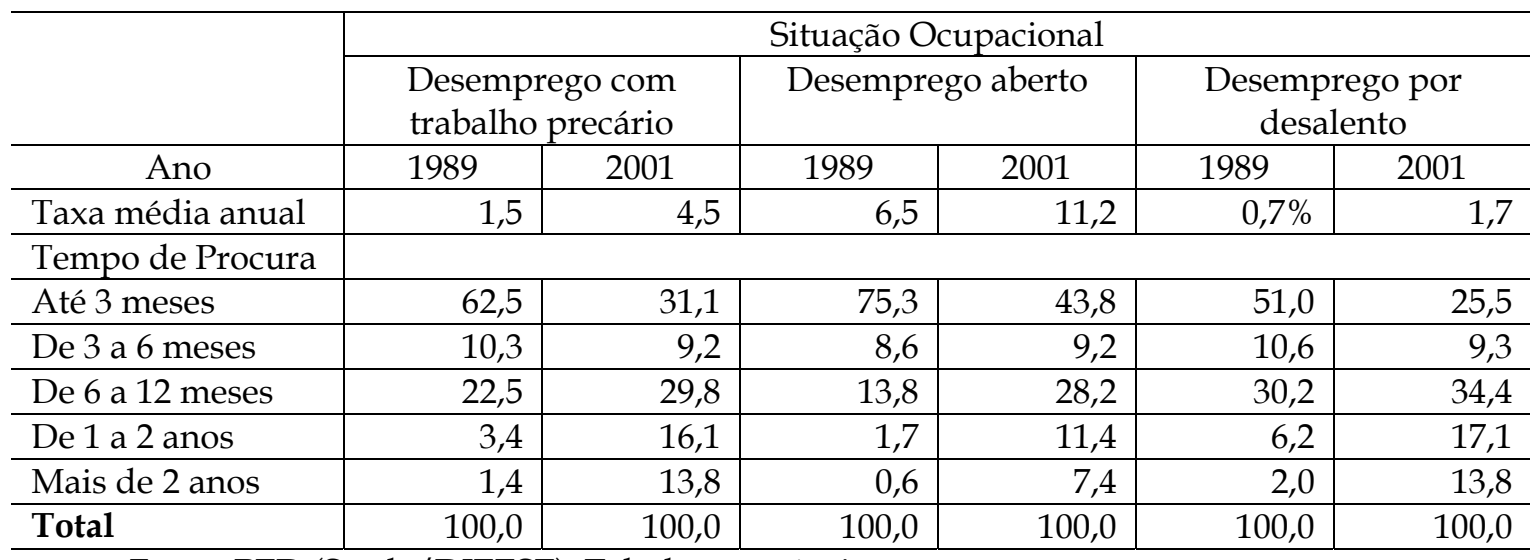

Fonte: PED (Seade/DIEESE), Tabulação própria

Observando apenas o desemprego oculto pelo trabalho precário, em 1989, nota-se que a maior parte das pessoas que se encontra nessa situação $(72,8 \%)$ está sem trabalho há até seis meses. Isso pode indicar que o trabalho precário aparecia, então, como uma maneira de "se virar" durante o tempo de desemprego, gerando alguma renda. Se olhamos os dados de 2001, percebemos que a situação se inverte: a faixa de tempo que recobre o período de três a seis meses de procura concentra apenas $40,3 \%$ do total de desempregados; outros $29,8 \%$ se concentram na faixa que vai de seis meses a um ano e $29,9 \%$ se encontram na faixa que vai de 1 a mais de 2 anos. $O$ tempo de desemprego se alonga cada vez mais e, a despeito da ocupação em alguma atividade precária, diminuem as chances de retorno ao mercado formal, uma vez que a data do último registro se transforma em estigma, "sujando" a carteira de trabalho e desfazendo a identidade com a última função desempenhada ${ }^{35}$. Para melhor compreender os significados conjugados do longo tempo de desemprego e do ingresso no setor informal, seria necessária uma análise de tipo longitudinal, mas ainda assim os dados provocam a pensar se tais pessoas não realizaram uma transição sem volta para a informalidade ${ }^{36}$.

\footnotetext{
35 Arrisco essa interpretação, a despeito dos dados não serem suficientes para fazê-lo, tendo como referência o relato de vários entrevistados.

36 Para uma descrição das possibilidades de esclarecimento oferecidas pelas pesquisas longitudinais, ver Caruso e Pero (1997) e Guimarães (2002).
} 
O desemprego aberto, a categoria que concentra as pessoas cuja única atividade é a procura, também registra o aumento do tempo de procura, embora ainda concentre 53\% de pessoas que procuram até 6 meses (em 2001). Esse dado indica a dificuldade de permanência na situação de desemprego aberto, seja devido à falta de um sistema de seguridade social, seja devido à dificuldade de manter a expectativa de encontrar um novo trabalho. Não à toa, enquanto a taxa de desemprego oculto pelo trabalho precário triplicou durante o período analisado, e o desemprego oculto pelo desalento mais que dobrou, o desemprego aberto aumentou menos que 50\% o que significa sem dúvida um grande aumento mas indica que aquelas formas de desemprego que poderíamos chamar de "atípicas" aumentaram de modo muito mais veloz.

Quanto ao desemprego oculto pelo desalento, há que se ter em conta que, de acordo com a metodologia da PED, tratam-se de pessoas que estão sem trabalho há pelo menos 12 meses. A faixa de tempo de procura se refere à resposta dada à questão “Durante quanto tempo o sr (a) ficou (está) procurando trabalho?" (Seade, 2001: 31). É possível notar que esse tempo se alonga bastante: enquanto $61,6 \%$ das pessoas nessa situação procuravam trabalho por até 6 meses em 1989, e 8,2\% procuravam entre 1 a 2 anos ou por mais do que 2 anos, em 2001, 34,8\% procuravam por até 6 meses, e 30,9\% haviam procurado trabalho por 1 a 2 ou mais do que por 2 anos.

Pode-se perceber que a variável tempo de procura tem alguma importância explicativa para a diferenciação dos tipos de desemprego. Os dados parecem indicar a dificuldade de permanência na situação de desemprego aberto e a transformação do trabalho precário em forma "normal" de geração de renda (ou, por outro lado, a generalização dessa situação, incorporando à mão-deobra que nunca teve lugar no mercado formal de trabalho, os egressos desse mercado, ou seja, aqueles que deixaram de ter lugar) ${ }^{37}$. Os dados relativos ao desemprego oculto pelo desalento, uma vez que acompanham a tendência ao

\footnotetext{
37 De novo, os dados não permitiriam arriscar essa interpretação sem que fossem complementados com análises longitudinais; se arrisco tal interpretação é com referência à pesquisa de campo e às trajetórias das pessoas que encontrei.
} 
alongamento do tempo de procura indicam que essa situação está intimamente referida à situação do mercado de trabalho como um todo: alonga-se também o tempo visto como necessário para encontrar um novo posto de trabalho, e as pessoas persistem buscando por um tempo mais longo antes de desistir.

Os dados relativos ao tempo de procura e ao desemprego por desalento diferem dos dados encontrados em mercados de trabalho mais estruturados, nos quais o tempo de procura aparece como variável explicativa da maior importância, sinalizando as dificuldades de manutenção da identidade de trabalhador frente às mudanças no mundo do trabalho. Assim, naquele contexto, há uma correlação bastante direta entre o tempo de procura e o desalento (ver, por exemplo, Demazière (1995a), ao mostrar que quando se trata da situação de desalento, ainda que existam diferenças entre homens e mulheres - com maiores taxas de desemprego de longa duração para mulheres - e entre diferentes faixas etárias, o fator "tempo de desemprego" se sobrepõe a ambos como variável explicativa, principalmente em casos de tempo de desemprego superior a dois anos).

A partir dos dados analisados até aqui, é possível notar que há diferenças entre o desalento em 1989 e o de 2001, mas tais diferenças parecem indicar que o desalento, entre nós, segue de perto os movimentos do mercado de trabalho em geral: como aumentam as taxas de desemprego aberto e aumenta o tempo de procura de um modo geral, a tolerância a continuar procurando a despeito de não encontrar trabalho também aumenta. Isso pode indicar que, na raiz da situação do desalento, está o equacionamento, realizado pela pessoa, entre a situação geral - do mercado de trabalho - e sua situação individual. Tal equacionamento, então, define o que é ou não "normal", e orienta a escolha entre continuar ou parar de procurar ${ }^{38}$.

\footnotetext{
38 Essa hipótese ganha reforço a partir do relato dos entrevistados. Encontrei algumas pessoas que, após um período de desalento ou inatividade, voltavam a procurar emprego. Quando perguntadas sobre os motivos para terem decidido voltar a procurar, ao lado da necessidade de trabalhar vinha o relato da sensação, por terem ouvido na televisão ou no rádio a divulgação de pesquisas, de que as coisas estavam melhorando. Essa sensação, confrontada com a dificuldade persistente de encontrar emprego, acabava levando-os a constatar que nada havia melhorado.
} 
A Tabela 3, que traz os dados referentes à faixa etária, segundo o tipo de desemprego e incluindo os inativos, também mostra que importantes mudanças aconteceram durante o período considerado para a análise.

De modo geral, observa-se que, entre os desempregados, diminui o número de pessoas entre 10 e 17 anos. É interessante notar que a inatividade aumenta também nessas faixas etárias, sendo mais significativo o aumento entre jovens de 15 a 17 anos. Esses dados, principalmente se os pensamos em relação à Tabela 5, podem indicar tanto que tais jovens estão afastados do mercado de trabalho em virtude de passarem mais anos na escola, quanto podem indicar a sensibilidade à situação geral do mercado de trabalho, provocando a desistência da procura ou, reforçando a hipótese acima, a construção da empregabilidade por meio do aumento da escolaridade e da qualificação.

Tabela 3: Faixa Etária, por tipo de desemprego, mais inativos - 1989 e 2001 $(\mathrm{em} \%)$

\begin{tabular}{|c|c|c|c|c|c|c|c|c|}
\hline \multirow[b]{3}{*}{ Ano } & \multicolumn{8}{|c|}{ Situação Ocupacional } \\
\hline & \multicolumn{2}{|c|}{$\begin{array}{c}\text { Desemprego } \\
\text { com trabalho } \\
\text { precário }\end{array}$} & \multicolumn{2}{|c|}{$\begin{array}{l}\text { Desemprego } \\
\text { aberto }\end{array}$} & \multicolumn{2}{|c|}{$\begin{array}{l}\text { Desemprego } \\
\text { por desalento }\end{array}$} & \multicolumn{2}{|c|}{ Inativo Puro } \\
\hline & 1989 & 2001 & 1989 & 2001 & 1989 & 2001 & 1989 & 2001 \\
\hline Taxa média anual & 1,5 & 4,5 & 6,5 & 11,2 & 0,7 & 1,7 & nc & nc \\
\hline \multicolumn{9}{|l|}{ Faixa Etária } \\
\hline 10 a 14 anos & 6,3 & 1,9 & 12,2 & 3,7 & 8,9 & 4,0 & 27,5 & 25,9 \\
\hline 15 a 17 anos & 11,2 & 8,0 & 19,6 & 15,6 & 20,0 & 15,0 & 6,2 & 9,4 \\
\hline 18 a 24 anos & 27,6 & 27,6 & 32,0 & 34,8 & 27,3 & 24,1 & 8,9 & 8,4 \\
\hline 25 a 39 anos & 40,0 & 36,5 & 27,0 & 28,7 & 31,9 & 27,8 & 19,7 & 13,3 \\
\hline 40 anos e mais & 14,8 & 26,1 & 9,2 & 17,2 & 12,0 & 29,2 & 37,7 & 43,0 \\
\hline Total & 100,0 & 100,0 & 100,0 & 100,0 & 100,0 & 100,0 & 100,0 & 100,0 \\
\hline
\end{tabular}

Fonte: PED (Seade/DIEESE), Tabulação própria. nc: não calculado

Por outro lado, entre os desempregados, aumenta o número de pessoas que têm 40 anos e mais, observando-se a mesma mudança em relação aos inativos. É importante notar que se trata de uma faixa bastante ampla, o que poderia tornar difícil a análise (de início, optei por trabalhar com as mesmas faixas etárias utilizadas pela Fundação Seade, quando divulga os dados)

Para contornar essa possível dificuldade, testei trabalhar com os dados dessa faixa desagregados (vide Tabela 3b) e, surpreendentemente, a maior parte 
dos indivíduos, tanto nos dados de 1989 quanto nos de 2001, concentrava-se entre 40 e 50 anos. Isso significa que a faixa utilizada, mesmo que ampla, apreende bem o aumento do desemprego entre a população de mais de 40 anos. Porém, ela dificulta a visibilidade do fato de que esse desemprego atinge principalmente a população de 40 a 50 anos, portanto, pessoas em idade ativa que acabam sendo "empurradas" para fora do mercado de trabalho. Observa-se que a taxa de inatividade também aumenta para essa faixa, porém, ela aumenta mais na população acima de 50 anos e 60 anos, indicando que tal aumento se deve em grande medida ao envelhecimento da força de trabalho.

A partir da Tabela 3b, podemos ainda notar que as pessoas que têm entre 40 e 50 anos, além de mais sujeitas ao desemprego aberto, acabam também mostrando-se mais vulneráveis a resvalar para as outras formas de desemprego: o desemprego oculto pelo trabalho precário quase dobra e o desemprego oculto pelo desalento quase triplica para essa faixa etária. Como apontamos em relação ao tempo de procura, o incremento dessas outras formas de desemprego podem significar maior vulnerabilidade, mas também podem indicar a assunção das representações sociais do "empregado típico" - quanto mais circula a idéia de que "o empregador não pega pessoas com mais de 40 anos", maior a probabilidade daqueles que têm mais de 40 anos se afastarem da procura efetiva. Os dados indicariam, assim, não o envelhecimento da força de trabalho, mas sua precoce obsolescência.

Tabela 3b: Faixa Etária de 40 anos e mais, por tipo de desemprego - 1989 e 2001 $(\mathrm{em} \%)$

\begin{tabular}{|c|c|c|c|c|c|c|c|c|}
\hline & \multicolumn{8}{|c|}{ Situação Ocupacional } \\
\hline & \multicolumn{2}{|c|}{$\begin{array}{c}\text { Desemprego } \\
\text { com trabalho } \\
\text { precário }\end{array}$} & \multicolumn{2}{|c|}{$\begin{array}{l}\text { Desemprego } \\
\text { aberto }\end{array}$} & \multicolumn{2}{|c|}{$\begin{array}{l}\text { Desemprego } \\
\text { por desalento }\end{array}$} & \multicolumn{2}{|c|}{ Inativo Puro } \\
\hline Ano & 1989 & 2001 & 1989 & 2001 & 1989 & 2001 & 1989 & 2001 \\
\hline Taxa média anual & 1,5 & 4,5 & 6,5 & 11,2 & 0,7 & 1,7 & nc & nc \\
\hline Faixa Etária & & & & & & & & \\
\hline 40 anos e mais & 14,8 & 26,1 & 9,2 & 17,2 & 12,0 & 29,2 & 37,7 & 43,0 \\
\hline 40 a 50 anos & 11,0 & 19,5 & 6,7 & 11,7 & 6,2 & 17,4 & 10,6 & 10,9 \\
\hline 51 a 60 anos & 2,5 & 5,7 & 1,8 & 4,4 & 4,0 & 8,4 & 10,4 & 11,2 \\
\hline 60 anos e mais & 1,3 & 0,8 & 0,7 & 1,0 & 1,8 & 3,4 & 16,7 & 20,9 \\
\hline
\end{tabular}

Fonte: PED (Seade/DIEESE), Tabulação própria. nc: não calculado. 
Em relação à Tabela 3a, um comentário ainda deve ser feito em relação a um pequeno aumento do desemprego aberto na faixa dos 18 aos 24 anos e também dos 25 aos 39 anos. Quando se toma o desemprego oculto, seja ele por trabalho precário ou por desalento, observamos o contrário, há uma queda nas taxas de desemprego para essas duas faixas. A exemplo do que já expusemos acima, essas pequenas mudanças talvez estejam a indicar o deslocamento das representações quanto ao perfil do "empregado típico": esse intervalo breve de idade se transformou no intervalo breve da idade ativa e, por isso, os indivíduos insistem mais na procura. Ao mesmo tempo, a se levar em conta a Tabela 5, trata-se provavelmente de uma parcela da população com maior nível de escolaridade, o que reforça a hipótese de que são pessoas com maior potencial - real ou imaginário - de empregabilidade39.

Tabela 4: Sexo, por tipo de desemprego, mais inativos - 1989 e 2001 (em \%)

\begin{tabular}{|c|c|c|c|c|c|c|c|c|}
\hline \multirow[b]{3}{*}{ Ano } & \multicolumn{8}{|c|}{ Situação Ocupacional } \\
\hline & \multicolumn{2}{|c|}{$\begin{array}{c}\text { Desemprego } \\
\text { com trabalho } \\
\text { precário }\end{array}$} & \multicolumn{2}{|c|}{$\begin{array}{l}\text { Desemprego } \\
\text { aberto }\end{array}$} & \multicolumn{2}{|c|}{$\begin{array}{l}\text { Desemprego por } \\
\text { desalento }\end{array}$} & \multicolumn{2}{|c|}{ Inativo Puro } \\
\hline & 1989 & 2001 & 1989 & 2001 & 1989 & 2001 & 1989 & 2001 \\
\hline Taxa média anual & 1,5 & 4,5 & 6,5 & 11,2 & 0,7 & 1,7 & nc & $\mathrm{nc}$ \\
\hline Sexo & & & & & & & & \\
\hline Masculino & 68,4 & 62,3 & 50,7 & 42,1 & 33,0 & 34,3 & 27,9 & 34,5 \\
\hline Feminino & 31,6 & 37,7 & 49,3 & 57,9 & 67,0 & 65,7 & 72,1 & 65,5 \\
\hline Total & 100,0 & 100,0 & 100,0 & 100,0 & 100,0 & 100,0 & 100,0 & 100,0 \\
\hline
\end{tabular}

Quanto ao sexo, a mudança que chama imediatamente a atenção se refere à inversão da distribuição do desemprego aberto no que se refere ao sexo. Enquanto em 1989 há equilíbrio, em 2001 as mulheres passam a representar

\footnotetext{
39 Levanto tal hipótese a partir do universo de jovens encontrados em minha pesquisa, principalmente tendo em conta que a população que hoje têm em torno de 18 anos é uma população que cresceu sob os auspícios de pais que têm (ou tinham) a escolaridade em alta conta, realizando esforços imensos para garantir que os filhos completassem o $2^{\circ}$ grau. A "ficha" sobre esse aspecto só "caiu" em conversas com Maria Inês Caetano Ferreira, sobre sua pesquisa em uma favela da cidade de São Paulo. Seu trabalho tem o imenso mérito de tornar claras algumas das maneiras pelas quais a cidade constrói trajetórias e possibilidades de transgredi-las, mostrando, assim, de que modo o trabalho e seus significados estão imbricados às experiências do urbano, tanto no que se refere aos pais quanto aos filhos. Esta teia de relações, representações e espacialidades resulta em mais heterogeneidade, reposta, agora, como pluralidade da experiência urbana (Caetano, 2004).
} 
57,9\% dos indivíduos em situação de desemprego aberto. Esse dado não é facilmente explicável.

Uma primeira hipótese se refere à intensificação da entrada feminina no mercado de trabalho: mudanças culturais em relação ao papel da mulher na família; mudanças econômicas, que transformaram o trabalho feminino em parte imprescindível do orçamento doméstico e mudanças no próprio mercado de trabalho se constituem em estímulos para que mais mulheres se afirmem à procura de trabalho.

Por outro lado, a análise dos dados referentes aos outros tipos de desemprego nos oferece algumas outras possibilidades de análise.

Tomando os dados relativos ao desemprego oculto pelo trabalho precário e também ao desemprego oculto pelo desalento, observamos que não registram nenhuma mudança: enquanto o primeiro aparece como fundamentalmente masculino, o outro aparece como tipicamente feminino.

Isso significa dizer que, quanto ao sexo, o desemprego aberto realmente oculta duas realidades. A primeira, a de que os homens são mais vulneráveis a recorrer a trabalhos precários quando vivem situações de desemprego. A segunda, a de que mulheres estão mais sujeitas a desistir da busca, provavelmente porque seu papel, ainda que se tenha modificado ao longo dos anos tomados como referência, continua legitimando sua permanência no espaço da casa.

O último aspecto que vale notar, em relação a Tabela 4, se refere à composição da inatividade. Como se pode notar, a estrutura da inatividade, no que se refere ao sexo, se aproxima bastante da estrutura do desemprego oculto pelo desalento. Isso reforça a hipótese de que o desemprego aberto e as formas de medi-lo estão pautadas por critérios que definem o "desempregado típico", quanto à idade, ao sexo, ao nível de escolaridade ${ }^{40}$. Menos que expressar "a realidade" da dinâmica do mercado de trabalho, tais critérios operam também no sentido de legitimar ou não comportamentos e é assim que os homens, mesmo quando se toma o quadro desenhado pelo "desemprego total", ou seja,

\footnotetext{
${ }^{40}$ Ver, a este respeito, Maruani, 2002.
} 
quando tomamos os dados relativos às formas ocultas de desemprego, aparecem como trabalhadores - desempregados ou precariamente empregados, enquanto as mulheres transitam com mais facilidade ao espaço da casa, desistindo da procura. Tratam-se, é claro, de diferentes papéis socialmente legitimados, mas são aspectos importantes para a compreensão das figurações de desemprego, bem como das diferentes expectativas sociais em relação aos diferentes tipos de desempregados.

Tal hipótese é reforçada quando se observa a relação entre o tipo de desemprego vivido e a posição no ciclo de vida, o que aqui tentarei expor utilizando, em conjunto, as variáveis sexo e faixa etária, conforme as tabelas expostas a seguir.

A Tabela 4a indica que houve diminuição do desemprego aberto nas faixas dos 10 aos 17 anos, de modo geral, sem distinção quanto ao sexo. Nas duas faixas seguintes, porém, a variável sexo revela uma distinção importante pois a diferença entre homens e mulheres (com maiores taxas para estas), que em 1989 era de um pouco mais de um ponto percentual, passa a ser de mais de seis pontos em 2001. Esse dado nos sugere que a carreira reprodutiva não retira mais as mulheres do mercado de trabalho e revela também que são elas as mais sujeitas ao desemprego durante sua idade ativa.

Tabela 4a: Composição do desemprego aberto, por sexo e faixa etária, 1989 e $2001(\mathrm{em} \%)$

\begin{tabular}{|c|c|c|c|c|}
\hline (Ano - taxa média anual) & \multicolumn{2}{|c|}{$(1989-6,5 \%)$} & \multicolumn{2}{|c|}{$(2001-11,2 \%)$} \\
\hline Faixa Etária / Sexo & Masculino & Feminino & Masculino & Feminino \\
\hline De 10 a 14 anos & 8,1 & 4,2 & 2,1 & 1,6 \\
\hline De 15 a 17 anos & 8,5 & 11,1 & 6,8 & 8,8 \\
\hline De 18 a 24 anos & 15,9 & 16,2 & 14,2 & 20,6 \\
\hline De 25 a 39 anos & 12,9 & 14,1 & 10,9 & 17,8 \\
\hline Mais de 40 anos & 5,4 & 3,8 & 8,1 & 9,1 \\
\hline Total & 50,7 & 49,3 & 42,1 & 57,9 \\
\hline
\end{tabular}

Fonte: PED (Seade/DIEESE) Tabulação própria

A Tabela 4b, por sua vez, que traz os dados relativos ao desemprego oculto pelo trabalho precário, mostra novamente que há diminuição da ocorrência desse tipo de desemprego na faixa que abrange dos 10 aos 17 anos - 
e esta diminuição é bem mais acentuada para os homens: pouco mais de $3 \%$ para eles, enquanto para elas a ocorrência deste tipo de desemprego diminui cerca de $0,5 \%$.

Tabela 4b: Composição do desemprego oculto pelo trabalho precário, por sexo e faixa etária, 1989 e 2001 (em \%)

\begin{tabular}{|c|c|c|c|c|}
\hline (Ano - taxa anual) & \multicolumn{2}{|c|}{$(1989-1,5 \%)$} & \multicolumn{2}{|c|}{$(2001-4,5 \%)$} \\
\hline Faixa Etária / Sexo & Masculino & Feminino & Masculino & Feminino \\
\hline De 10 a 14 anos & 5,2 & 1,1 & 1,1 & 0,8 \\
\hline De 15 a 17 anos & 8,3 & 2,9 & 5,7 & 2,3 \\
\hline De 18 a 24 anos & 16,5 & 11,1 & 18,2 & 9,4 \\
\hline De 25 a 39 anos & 26,8 & 13,2 & 21,1 & 15,5 \\
\hline Mais de 40 anos & 11,6 & 3,3 & 16,3 & 9,8 \\
\hline Total & 68,4 & 31,6 & 62,3 & 37,7 \\
\hline
\end{tabular}

Fonte: PED (Seade/DIEESE) Tabulação própria

Entre os homens, nota-se que este tipo de desemprego aumenta na faixa de 18 a 24 anos e na de mais de 40 anos - aqueles que seriam os pontos extremos das trajetórias de trabalho. Entre as mulheres, aumenta a ocorrência de desemprego oculto pelo trabalho precário para aquelas que têm entre 25 e 39 anos e, mais acentuadamente, entre aquelas com mais de 40 anos (triplicando durante o período considerado).

A Tabela 4c traz os dados relativos ao desemprego oculto pelo desalento.

Tabela 4c: Composição do desemprego oculto pelo desalento, por sexo e faixa etária, 1989 e 2001 (em \%)

\begin{tabular}{|c|c|c|c|c|}
\hline (Ano - taxa média anual) & \multicolumn{2}{|c|}{$(1989-0,7 \%)$} & \multicolumn{2}{|c|}{$2(001-1,7 \%)$} \\
\hline Faixa Etária / Sexo & Masculino & Feminino & Masculino & Feminino \\
\hline De 10 a 14 anos & 5,5 & 3,3 & 12,8 & 13,1 \\
\hline De 15 a 17 anos & 6,1 & 13,5 & 4,4 & 5,1 \\
\hline De 18 a 24 anos & 9,1 & 18,2 & 2,5 & 5,8 \\
\hline De 25 a 39 anos & 7,1 & 24,8 & 2,1 & 11,2 \\
\hline Mais de 40 anos & 4,9 & 7,1 & 12,8 & 30,3 \\
\hline Total & 33,0 & 67,0 & 34,5 & 65,5 \\
\hline
\end{tabular}

Fonte: PED (Seade/DIEESE) Tabulação própria

Primeiro ponto que chama a atenção: o imenso crescimento dessa situação entre crianças de 10 a 14 anos, independentemente do sexo. Nas faixas seguintes, seja para homens, seja para mulheres, diminui a freqüência deste tipo 
de desemprego - e para as mulheres, absoluta maioria na experiência do desemprego por desalento, a diminuição é mais acentuada. Mas o que impressiona mesmo é o crescimento das taxas entre pessoas com mais de 40 anos. Mais de metade das mulheres que se encontram em desemprego por desalento em 2001 tem mais de 40 anos; entre os homens, um terço dos que se encontram nessa situação em 2001 também tem mais de 40 anos.

O que a análise desses dados, que combinam tipo de desemprego, sexo e idade, pode nos indicar? De modo geral, eles confirmam que cada um dos tipos de desemprego revela aspectos importantes sobre as diferentes realidades vividas por homens e mulheres. As mudanças ocorridas nas taxas de desemprego aberto mostram que a intensa entrada das mulheres no mercado de trabalho é um importante sintoma de que mudanças sócio-culturais aconteceram na última década, mas ao mesmo tempo indicam que elas são mais vulneráveis a estarem desempregadas do que os homens.

Complementando essa interpretação, verifica-se que o desemprego oculto pelo trabalho precário continua se referindo principalmente aos homens. Porém, a concentração das pessoas que vivem essa situação nas faixas etárias que marcam o início e o final da participação no mercado de trabalho, dão noticia do estreitamento do período de atividade, devido à crescente necessidade de escolarização e à obsolescência precoce dos trabalhadores. São os jovens e os mais velhos, os que estão ingressando e os que estão em vias de sair, os que estão mais sujeitos a experimentarem a situação de desemprego oculto pelo trabalho precário.

O desemprego oculto pelo desalento, por sua vez, continua também se referindo às mulheres; mas a variável faixa etária indica um deslocamento importante: os dados sugerem que o desalento deixa de ser uma prerrogativa das mulheres em idade ativa, que transitavam para a inatividade a despeito de sua vontade de trabalhar. Conforme apontei, entre tais mulheres o desalento diminui bastante entre 1989 e 2001.

As mulheres que passam a experimentar o desalento são mulheres mais velhas, assim como mais velhos são os homens nessa situação - dessa maneira, 
embora em 1989 a categoria desemprego oculto pelo desalento exercesse papel importante para explorar as fronteiras entre desemprego e inatividade, revelando que as mulheres ficavam "fora da conta" do desemprego devido às representações sobre seu lugar social, talvez os dados de 2001 estejam a dar notícia de um importante deslocamento: atingindo principalmente pessoas mais velhas, o desemprego por desalento hoje pode estar se tornando mais atrelado à variável tempo de procura, conjugada com a falta de perspectivas de retorno, devido à circulação de idéias e valores bastante restritivos acerca dos critérios de empregabilidade. Além disso, como já chamei a atenção a partir da Tabela 2b, o desemprego (dos três tipos) aumentou muito na faixa dos 40 anos e mais, atingindo principalmente as pessoas que têm entre 40 e 50 anos; pessoas, portanto, que ainda estão em idade ativa.

Na Tabela 5, podemos notar, à primeira vista, o aumento geral do nível de escolaridade, que certamente não está restrita apenas aos desempregados, mas caracteriza a mão-de-obra em geral.

Observando os dados de 1989, apenas em relação ao desemprego aberto, notamos que havia $5 \%$ de analfabetos e $62,2 \%$ de pessoas sem o ensino fundamental completo. Em 2001, os analfabetos são 3\% e as pessoas sem o ensino fundamental completo $34,5 \%$, uma imensa diferença portanto. Se nos concentrarmos na faixa que abrange pessoas com ensino médio completo e ensino superior incompleto, a diferença é ainda mais visível: 8,8\% em 1989 e 28,1 \% em 2001, o que mostra que os indivíduos não apenas completaram mais o ensino fundamental, mas permaneceram na escola por mais tempo.

Tais mudanças se devem a um entrecruzamento de fatores tais como o aumento do tempo médio de anos de estudo ${ }^{41}$ e a constituição de novos padrões de empregabilidade.

\footnotetext{
41 Segundo dados do IBGE, entre 1996 e 1999 houve uma queda de 2,5\% nas taxas de analfabetismo entre pessoas de 10 anos ou mais, sendo que entre pessoas de 10 a 14 anos, essa queda foi bem mais acentuada, de $4,5 \%$. No entanto, ainda que as taxas de analfabetismo sejam decrescentes nos últimos anos, se somadas às taxas das pessoas com pouca escolaridade, a população incluída nessas situações chega a 40\% (Incluímos aqui as pessoas com menos de 3 anos de instrução, ou seja, sem completarem ao menos a $4^{\text {a }}$ série, hoje tida como o período necessário à consolidação da alfabetização. Os dados utilizados são na Pesquisa Nacional de
} 
Tomando o desemprego oculto pelo trabalho precário, notamos que tanto em 1989 quanto em 2001, os indivíduos que se encontram nessa situação apresentam grau de escolaridade inferior àquela apresentada pelas pessoas em desemprego aberto ou em desemprego oculto pelo desalento, revelando a vulnerabilidade de tais pessoas em relação ao mercado formal de trabalho.

Quando observamos as mudanças ocorridas em relação ao desemprego oculto pelo desalento, percebemos duas coisas. A primeira é que, em 1989, se considerarmos as faixas que abrangem as pessoas com ensino médio completo + superior incompleto e superior completo, as pessoas que se encontravam nessa situação apresentavam grau escolaridade superior a daquelas que se encontravam em desemprego aberto. Isso poderia indicar que as pessoas alocadas nessa categoria, em 1989, por se tratar de pessoas com mais escolaridade, eram pessoas portadoras de um estatuto, definido a partir de um tipo de inserção no mercado de trabalho ${ }^{42}$.

\footnotetext{
Amostra por Domicílio, PNAD - 2001). Ainda, a partir dos dados, é possível perceber que, enquanto a taxa de analfabetismo cai mais rapidamente entre os jovens (51,8\% em 3 anos); entre as pessoas mais velhas ela cai com bem menos velocidade (17,9\% para o mesmo período), revelando a dificuldade em sanar as deficiências escolares na vida adulta.

42 Os dados da PED não permitem afirmar que existe uma identidade entre escolaridade e qualificação. No entanto, se observamos, por exemplo, a Pesquisa de Orçamento Familiar - POF (DIEESE) e as diferentes composições familiares por estrato de renda, obtemos informações importantes que ampliam o entendimento dos diferentes tipos de inserção que encontram na escolaridade um importante fator de explicação: "Um segundo aspecto que se observa (nos dados da POF de 1995) diz respeito à brutal diferença do nível educacional entre as famílias. Neste caso, tratase de um indicador mais evidente para explicar um baixo padrão de vida e sua reprodução. Nota-se que 10,4\% (dos chefes de família do estrato inferior de renda) não possuem nenhuma instrução e $25 \%$ só o primário incompleto, ou seja, enquanto um quarto dos chefes de família do estrato superior tem grau universitário, cerca de 50,6\% deles no estrato inferior, excluídos os sem instrução, concluiu somente o antigo primário (1 $1^{a}$ a $4^{a}$ séries)", (DIEESE, 1995).
} 
Tabela 5: Nível de escolaridade, por tipo de desemprego, mais inativos - 1989 e

Dados:PED (SEADE/DIEESE), Tabulação própria

A relação entre o desemprego aberto e o oculto pelo desalento, no que se refere à faixa mencionada acima, inverte-se em 2001. O nível de escolaridade dos indivíduos que se encontram em desemprego oculto pelo desalento se torna mais baixo, em relação ao desemprego aberto.

Assim, em 2001, notamos que o desemprego oculto pelo desalento passa a concentrar mais pessoas analfabetas ou com ensino fundamental incompleto em relação ao desemprego aberto.

\section{O que revela a categoria "desemprego por desalento" hoje? - A partir} dos dados analisados acima, é possível sugerir que houve alguns deslocamentos importantes desde quando a PED foi concebida até hoje, mudando a situação circunscrita por meio da categoria desemprego por desalento.

Vale lembrar, a PED foi desenhada em 1984, a partir da experiência de 1983 da Pesquisa das Condições de Vida - PCV, realizada pelo DIEESE. O 
objetivo era, como já foi dito, criar categorias que pudessem captar as situações ocupacionais que ficavam subsumidas nas tradicionais categorias emprego, desemprego (aberto) e inatividade.

Como observa-se nos dados, o desemprego oculto pelo desalento segue de perto os movimentos dos outros tipos de desemprego, indicando as relações que guardam entre si, em relação a um mesmo mercado de trabalho.

As análises realizadas, em relação aos dados de 1989, sugerem que a categoria circunscrevia a situação de pessoas cujo tempo de procura por um novo trabalho era superior ao de pessoas que viviam outros tipos de desemprego. A categoria também concentrava, em relação aos outros tipos de desemprego, pessoas entre 10 e 17 anos, com mais de 40 anos e mulheres em idade ativa - reforçando a hipótese de que o desalento teria como fronteira a inatividade - e, finalmente, em relação ao nível de escolaridade, a categoria concentrava pessoas com nível médio completo e superior, completo e incompleto.

Desse modo, tais dados sugerem que a categoria desemprego oculto pelo desalento operava como reveladora das situações facilmente confundíveis com a inatividade, pensando-as a partir da noção de direito ao trabalho e pondo no centro da discussão não o comportamento de procura efetiva, mas a vontade/necessidade de trabalhar.

A situação que acabamos de descrever muda bastante quando observamos os dados relativos a 2001. Em relação ao tempo de procura, observamos que, ainda que este seja bastante superior ao tempo de procura que caracteriza o desemprego aberto, trata-se de uma média bastante próxima ao do desemprego oculto pelo trabalho precário, o que sugere que a variável tempo de procura é muito importante quando se trata de conferir visibilidade ao desemprego. Quanto maior o tempo de desemprego, maior a probabilidade de que ele se torne oculto. Isso pode significar que, a despeito da constatação geral do aumento do tempo da procura, persiste ainda a representação social do desemprego como um tempo de transição e este tempo opera delimitando aqueles que são ou não desempregados stricto senso, seja pela necessidade de aceitar 
qualquer "bico" - sendo deslocados para o desemprego por trabalho precário -, seja conformando-se a outros espaços, abandonando a identidade com o trabalho.

Em relação à idade, observamos que diminui para menos da metade a porcentagem de pessoas que estão na faixa entre 10 e 17 anos, a categoria desemprego oculto pelo desalento concentrando menos pessoas nessa faixa em relação às outras categorias. De outro lado, observamos o aumento de pessoas nessa faixa etária que são inativas. À luz dos dados relativos ao nível de escolaridade, levantamos a hipótese de que tal mudança revela o maior tempo de permanência dos jovens na escola, em busca de atender os novos padrões de empregabilidade. Por outro lado, observamos que a categoria, além de concentrar as pessoas com 40 anos e mais (das quais 17,4\% têm entre 40 e 50 anos), registra um aumento nessa faixa etária de quase $200 \%$, passando de $12 \%$ a $29 \%$. Esse dado dá notícia do envelhecimento da mão-de-obra, mas também de sua precoce obsolescência, empurrando pessoas com mais de 40 anos ou para o trabalho precário ou para a inatividade.

Quanto ao sexo, não há nenhuma mudança: o desemprego oculto pelo desalento é fundamentalmente feminino e, a despeito da intensa entrada feminina no mercado de trabalho, a categoria continua capturando a situação das mulheres, que transitam mais facilmente para a inatividade. Quando confrontamos esse dado com as mudanças ocorridas em relação ao desemprego aberto e ao desemprego oculto pelo trabalho precário, temos notícia da persistência de representações sociais sobre o lugar da mulher.

Por outro lado, quando conjugadas as variáveis sexo e faixa etária, um importante deslocamento aparece, em relação a 1989, pois encontramos um grande aumento de homens e mulheres, com mais de 40 anos, em situação de desemprego por desalento. A idade, assim, parece estar se sobrepondo ao sexo como variável explicativa - pelo menos para essa faixa etária. Esse dado reforça a interpretação sobre obsolescência precoce, à qual me referi acima.

Finalmente, quanto ao nível de escolaridade, observamos que a categoria passa a concentrar pessoas analfabetas e com o ensino fundamental incompleto, 
indicando um importante deslocamento em relação ao que a categoria capturava em 1989.

A partir da discussão sobre a historicidade das formas de construir a categoria "desemprego" e da apresentação dos dados da PED, que contribuem para a exploração dos limites das fronteiras da categoria, estabelece-se um importante conjunto de questões pois que, se é verdade que a categoria "desemprego oculto pelo desalento" é capaz de tornar um pouco menos cinzento o "halo do desemprego", contribuindo para distinguir os diferentes tipos de desemprego tornados possíveis em nossa sociedade, é preciso também reconhecer que a análise dos dados não é suficiente para sinalizar a direção das mudanças ou seus significados para a vida dos indivíduos.

Desse modo, a partir dos dados, é possível construir uma espécie de perfil em relação aos indivíduos que estão mais sujeitos a experimentar um ou outro tipo de desemprego. Mas não é possível compreender a complexidade de relações sociais que o levam até um ou outro. Em outras palavras, ainda assim não é possível apreender o sentido que a categoria "desemprego oculto pelo desalento" ganha na experiência de quem o vive.

No capítulo seguinte, descrevo o percurso do trabalho de campo e as escolhas metodológicas que fiz, tentando relacioná-las, na medida do possível, com as questões levantadas aqui. Com a realização de entrevistas, tratava-se de conhecer a história de trabalho, o percurso que conduz os indivíduos à situação de desalento; tratava-se, portanto, de levantar elementos que permitissem arriscar mais interpretações sobre os significados do desalento, contribuindo para preencher alguns dos espaços vazios evidenciados a partir do que foi exposto nesse capítulo. 


\section{Capítulo 2 - Procedimentos de Pesquisa}

Neste capítulo, tratarei de descrever a metodologia do trabalho de campo, não somente relatando as escolhas que foram feitas e suas razões, mas também refletindo sobre meu próprio papel e as maneiras pelas quais a relação estabelecida com os entrevistados, desde o espaço físico no qual ocorreu o contato até a forma de abordá-los, ilumina os achados de campo, ajudando a compreendê-los a partir de seu contexto.

Primeiro, descrevo as dificuldades encontradas na realização do trabalho de campo, o modo de enfrentá-las e as decisões tomadas para superá-las; enfim, faço o relato do "curso das coisas", procurando, concomitantemente, fazer a crítica do processo - que é ao mesmo tempo de pesquisa e de reconstrução de seu objeto.

Em seguida, na seção intitulada "Achados de Campo", cuidarei de apresentar o universo de indivíduos pesquisados, apresentando um perfil no que se refere aos seus atributos pessoais.

O objetivo desse capítulo é, então, esclarecer alguns aspectos sobre o contexto em que vive o conjunto de entrevistados e, a partir disso, "puxar" alguns fios que nos serão importantes para a tessitura da reflexão sobre os significados do trabalho e do desemprego hoje.

Na seção "Achados de Campo", assim, apresento o perfil do conjunto de entrevistados para sublinhar que, embora as sete histórias de trabalho selecionadas para a análise mais aprofundada sejam particulares, os problemas sociológicos que elas permitem construir estão embebidos da experiência que tive a partir do conjunto das entrevistas realizadas.

\section{A constituição do Campo}

De início, quando da formulação inicial do projeto de pesquisa, havia definido como "campo" os beneficiários do Programa Começar de Novo que 
houvessem optado, após o fim do período de bolsa, pelo Projeto Oportunidade Solidária ${ }^{43}$.

O Programa Começar de Novo tem como público-alvo a população com mais de 40 anos, com o objetivo de geração de trabalho e renda. Sendo de caráter redistributivo, os beneficiários recebem bolsas por um período de 6 meses, durante os quais se comprometem com as atividades oferecidas pelo Programa - que inclui cursos de cidadania, sensibilização para a economia solidária e cursos de capacitação profissional, tais como informática, costura, estamparia, entre outros. Ao fim desse período, aqueles que desejarem podem participar das atividades do Projeto Oportunidade Solidária, cujo objetivo é a criação de alternativas para a geração de trabalho e renda, notadamente os empreendimentos coletivos autogestionários e cooperativas.

A escolha pelos beneficiários se apoiava em duas razões: a primeira era prática, referente à facilidade de acesso, uma vez que eu havia atuado, junto ao Serviço Nacional de Aprendizagem do Cooperativismo - Sescoop/SP, formando "Multiplicadores de Cooperativismo"; a outra razão era metodológica: inseridos em coletivos, buscando alternativas de geração de trabalho e renda, o espaço das aulas muitas vezes também se transforma em espaço de reelaboração da própria identidade e da relação com o trabalho. Para um trabalho que se interroga sobre as novas formas de enraizamento, esse aspecto era bastante fundamental.

O motivo que me levou a abandonar essa idéia inicial foi, principalmente, de natureza metodológica.

\footnotetext{
${ }^{43}$ Ambos os projetos se inserem no escopo da "Estratégia Paulistana de Combate à Pobreza, ao Desemprego e à Desigualdade", formulada pela Secretaria de Desenvolvimento, Trabalho e Solidariedade (SDTS) da Prefeitura Municipal de São Paulo, que está dividida em três eixos de programas - Redistributivos, Emancipatórios e Apoio ao Desenvolvimento Local. A estratégia parte do diagnóstico de que a pobreza, a desigualdade e o desemprego constituem problemas inter-relacionados, passíveis de serem resolvidos pelo mesmo conjunto de ações. Os programas, em seu encadeamento, têm por objetivo final a criação de novos empreendimentos, preferencialmente coletivos, o que constitui um interessante deslocamento em relação aos programas de requalificação profissional. A SDTS tem feito parcerias com organizações e entidades com experiência em geração de Trabalho e Renda, privilegiando aquelas que estimulem empreendimentos coletivos (em 2003, apenas uma das entidades envolvidas tem como experiência o apoio a empreendimentos individuais).
} 
As primeiras leituras, notadamente aquelas para aprofundar $\mathrm{O}$ conhecimento sobre a metodologia da PED, acabaram por me mostrar que o universo do desemprego por desalento era bastante diverso daquele constituído pelos beneficiários do Começar de Novo.

Nesse momento, tão característico das crises e dos diversos caminhos que somos levados a escolher ao longo de uma pesquisa, impôs-se a questão de reformular, repensar e reordenar os problemas a serem tratados pela pesquisa. Naquela ocasião, pareceu-me que, para ser fiel ao conjunto de interrogações que constituíam o projeto, era necessário realizar as entrevistas com pessoas cuja situação, de fato, as aproximasse o mais possível dos critérios definidos pela PED44.

As leituras sobre a metodologia da PED, porém, tornavam cada vez mais claras as dificuldades envolvidas na tentativa de "operacionalizar", no âmbito de uma pesquisa qualitativa realizada por apenas um pesquisador, as categorias de uma pesquisa quantitativa, de tipo domiciliar, realizada por toda uma equipe e que conta com uma série histórica de 20 anos.

Desse modo, procurando garantir que os entrevistados fossem pessoas que, a partir dos critérios da PED seriam contabilizadas como desempregados por desalento, entrei em contato com a Fundação SEADE, com o pedido de acesso aos dados de pessoas que houvessem sido classificadas na categoria de “desemprego oculto por desalento" ou, caso não fosse possível, com o pedido de acompanhar os pesquisadores de campo. Nenhuma das propostas foi aceita, devido ao compromisso de sigilo das informações pessoais fornecidas pelos pesquisados.

A solução encontrada foi, então, entrar em contato com outras instituições que têm contato direto com desempregados, mesmo correndo o risco de deslocar um pouco o universo de pesquisa. Por sugestão de minha orientadora,

\footnotetext{
${ }^{44}$ Nesse sentido, os beneficiários do Programa Começar de Novo, por suas trajetórias, pareciam se aproximar mais da situação de desemprego oculto pelo trabalho precário; aliás, este se tornou um dos problemas enfrentados quando do término da bolsa - finda a bolsa, os beneficiários retomavam suas atividades (na maior parte das vezes, "bicos") e deixavam de ter tempo para dedicar ao Programa Oportunidade Solidária.
} 
entrei em contato com o Centro de Solidariedade do Sindicato dos Metalúrgicos de Osasco e Região, que abriu espaço para realização de entrevistas em suas dependências.

\section{O Centro de Solidariedade de Osasco}

Os Centros de Solidariedade são uma iniciativa da Força Sindical. Além de funcionarem como uma "agência de empregos", cadastrando e encaminhando trabalhadores e recebendo a demanda de empresas, entre os serviços oferecidos pelos Centros estão: cursos de qualificação e requalificação profissional, juntas de conciliação prévia e encaminhamento dos trâmites necessários para o recebimento do seguro-desemprego.

Existem cinco centros no estado de São Paulo: dois no município de São Paulo (Liberdade e Santo Amaro), três na Região Metropolitana de São Paulo (Osasco, Guarulhos e Santo André) e três na região Nordeste (Recife, Olinda e Camaçari). Também existem postos avançados, que funcionam localmente nos sindicatos.

O Centro de Solidariedade de Osasco é um prédio grande, de três andares. Na mesma rua, logo em frente, fica a sede do Sindicato dos Metalúrgicos de Osasco e Região, filiado à Força Sindical.

O Centro está sempre cheio, atendendo tanto a população de Osasco quanto a população da zona Oeste de São Paulo. Existem pessoas na fila desde antes das cinco horas da manhã: o número de senhas distribuído a cada dia é limitado e as pessoas procuram chegar cedo para não ficarem sem atendimento e também para saírem ainda a tempo de procurar em outros lugares e agências, minimizando os custos da saída de casa (conforme os relatos dos entrevistados). O único requisito para ser atendido é portar a carteira de trabalho.

O Centro só abre às oito horas da manhã, quando começa a distribuição das senhas. No terceiro andar, existem cadeiras (mais ou menos 200), para que as pessoas possam aguardar sentadas e abrigadas do sol ou da chuva. Trata-se de um salão grande, com duas televisões que só são desligadas quando a psicóloga do Centro faz alguma comunicação, em geral com o objetivo de 
motivá-los e também de dar algumas "dicas" de comportamentos que aumentam suas chances de se empregar (dicas que vão desde a "disposição interna" para a procura até a adequação das roupas e acessórios para uma entrevista de trabalho $)^{45}$.

As televisões também são desligadas quando um empregador, com muita urgência para contratação, leva uma lista ao Centro. Um funcionário, então, vai lendo as vagas e as exigências e aqueles que se interessarem podem acompanhá-lo para pegar a carta de encaminhamento.

Um funcionário é responsável pela organização da fila, controlando o número de pessoas a descerem, de acordo com o andamento do atendimento. Periodicamente, grupos de pessoas descem, aguardando durante mais algum tempo no térreo. Os atendentes, em pequenos terminais, vão então preenchendo o cadastro, interrogando as pessoas sobre sua experiência, profissão, escolaridade, área em que deseja se reinserir... Não é preciso que o trabalhador preencha nenhuma ficha - já que o cadastro é feito pelos atendentes do Centro - e, se houver vagas disponíveis na área de atividade do trabalhador desempregado, ele já sai de lá com uma carta de encaminhamento. Esse aspecto é bastante valorizado pelas pessoas, que percebem que o Centro lhes oferece uma resposta mais imediata, sem que elas precisem "ir para casa e aguardar", a exemplo do que acontece nas agências.

Desde que comecei o trabalho de campo, em outubro de 2002, até hoje, o Centro de Solidariedade se modificou. Entre março e setembro de 2003, interrompi as entrevistas, pois já havia acumulado algum material e foi necessário suspender o trabalho de campo para a análise dos primeiros dados. Quando voltei às entrevistas, a estrutura do Centro de Solidariedade de Osasco estava bastante diferente.

Devido aos cortes realizados no repasse do Fundo de Amparo ao Trabalhador - segundo as explicações dos funcionários do Centro - muitos funcionários haviam sido demitidos. Com isso, a capacidade de atendimento do

\footnotetext{
45 Apenas um breve comentário sobre os canais sintonizados nessas televisões: National Geographic ou filmes da TNT.
} 
Centro ficou reduzida em torno de um terço: em vez de 1.000 pessoas por dia, passou-se a atender entre 300 e 350. O tempo de espera também aumentou consideravelmente: enquanto antes, por volta das duas da tarde, quase todas as pessoas já haviam passado pelo atendimento, agora muitas pessoas não conseguem sair antes das cinco da tarde.

A despeito disso, o Centro apareceu na fala dos entrevistados como um importante local para a procura de trabalho, pela facilidade de acesso, pela centralização de ofertas de vagas de diversas empresas, por oferecer uma resposta mais rápida (na medida em que haja vagas) e por se tratar de um espaço visto como "mais democrático", no sentido de não operar as discriminações de idade ou cor.

\section{O início do trabalho de campo}

Comecei a fazer as entrevistas em outubro de 2002. Quando comecei, geralmente chegava ao Centro às oito da manhã, e a fila era sempre imensa: o Centro atendia, em média, 1.000 pessoas e, como há distribuição de senhas, quanto mais cedo se chega, maior a garantia de atendimento. Após as nove horas da manhã, rareavam as pessoas chegando, pelo menos aquelas em busca de atendimento ${ }^{46}$.

As entrevistas foram feitas com pessoas que vão ao Centro procurar emprego. Está claro que a procura ativa de emprego poderia constituir uma dificuldade metodológica, já que a desistência da procura nos últimos 30 dias é um dos critérios chave para a identificação da situação de desemprego por desalento ${ }^{47}$.

No esforço de encontrar aqueles que poderiam ser categorizados como desempregados por desalento em algum momento de sua trajetória, realizei

\footnotetext{
${ }^{46}$ Atualmente, essa situação se modificou: as senhas passaram a ser distribuídas a partir das seis horas da manhã e por volta das oito horas, já não há mais senhas disponíveis. Com isso, muitas pessoas chegam à fila por volta das quatro horas da manhã. Como não há transporte público nesse horário, muitos têm que caminhar até o Centro.

${ }^{47}$ Vale lembrar, os outros critérios são: realização de procura no período de 12 meses; não haver realizado nenhum atividade econômica no período de 30 dias, desejar trabalhar e estar disponível para o início imediato do trabalho, caso apareça uma oportunidade.
} 
entrevistas com pessoas que estavam desempregadas há mais de doze meses e que, por qualquer razão, tivessem deixado de procurar trabalho por algum período (mínimo de um mês) durante esse tempo de desemprego.

Durante a realização do primeiro conjunto de entrevistas, localizava pessoas que se encaixassem na situação descrita acima enquanto elas esperavam pelo atendimento. Na sala de espera do terceiro andar - na qual, antes das mudanças ocorridas no Centro, se concentravam mais ou menos duzentas pessoas, nos dias normais -, me apresentava como alguém que estava fazendo um trabalho de faculdade e que, para isso, precisava conversar com algumas pessoas. Depois, pedia para que aqueles que estivessem desempregados há um ano ou mais levantassem a mão. A esses, então, perguntava quantos haviam deixado de procurar - por qualquer motivo durante um período de pelo menos um mês.

Geralmente, apesar do grande número de pessoas presentes na sala, nunca conseguia falar mais do que com três pessoas. Muitos ficavam me olhando desconfiados; outros, olhavam em volta, verificando se havia pessoas naquela situação, antes de levantar a mão. De um modo geral, se admitir o longo período de desemprego já era difícil, admitir o período de não-procura era ainda mais complicado. Muitas pessoas, após a segunda pergunta, balançavam a cabeça, como a dizer "isso não, isso nunca...".

De toda maneira, após identificar algumas pessoas, ia chamando uma a uma na sala - uma pequena sala cedida pelo Centro de Solidariedade - e realizava a primeira entrevista, com o objetivo de montar um pequeno "banco de histórias" a partir do qual pudesse 1) identificar temas e aspectos importantes para lançar luz sobre a situação de desemprego oculto pelo desalento e 2) selecionar as narrativas de trabalho de pessoas em situação de desemprego por desalento para a análise aprofundada. Na primeira fase de entrevistas, conversei com 26 pessoas.

O tempo de duração das entrevistas, ainda que o objetivo principal fosse identificar o tipo de desemprego vivido (cf. Anexo 1.1) era bastante variável, durando de quinze a quarenta minutos. 
Já na sala, explicava novamente à pessoa quem era eu, por que queria entrevistá-la e pedia permissão para gravar (mesmo que o pedido às vezes provocasse algum embaraço ou constrangimento, apenas um entrevistado não quis que o gravador fosse ligado). As entrevistas se concentraram sobre a história de trabalho das pessoas: tempo de desemprego, motivos que levaram à interrupção da procura, dificuldades que encontram ou identificam após o tempo prolongado de desemprego, mudanças ocorridas em sua vida em razão do desemprego etc. (cf. Anexo 1.1). Terminada a entrevista, eu perguntava sobre a possibilidade de voltar a falar com a pessoa e ficava com um telefone de contato $^{48}$.

Logo no início do trabalho de campo, eu tinha algum receio em relação aos entrevistados homens, adultos. Temia que eles não quisessem falar comigo, principalmente sobre as razões de seu desemprego. Na base desse receio estava uma representação social bastante comum, a de que o desemprego põe em risco a "masculinidade" do homem adulto, sua capacidade de "gerar a sobrevivência" de si e de sua família. Imaginava que essa sensação de ameaça provocaria a recusa a falar comigo, com o agravante de eu ser mulher.

No entanto, todos os homens que entrevistei foram bastante solícitos, principalmente quando eu explicava que estava fazendo um trabalho para a faculdade - aqueles que têm filhos em idade escolar se dispunham a me ajudar, porque viam os esforços dos próprios filhos. Nesse "respeito" e "disponibilidade" está um importante dado, que é a importância atribuída à escolaridade, como algo que pode modificar os rumos e as possibilidades de trajetórias. Tanto que esse aspecto não apareceu apenas na fala dos "pais" (homens e mulheres). Quando entrevistava jovens que desejam fazer faculdade, eles me perguntavam sobre o curso, queriam saber se havia sido difícil entrar na USP, se dava para estudar e trabalhar e outras dúvidas relativas à

\footnotetext{
${ }^{48}$ Não fiquei com o contato de todos os entrevistados, no entanto, pois durante a entrevista já era possível perceber se a pessoa tinha estado na situação de desemprego oculto pelo desalento e, assim, só a essas pessoas pedia uma forma de contato.
} 
possibilidade de ingresso numa universidade pública e conciliação entre trabalho e estudos.

Um fato interessante foi que as entrevistas mais custosas - no sentido de exigirem mais a minha provocação para a obtenção de respostas - foram as que realizei com jovens do sexo masculino. Quando perguntados, raramente eles diziam mais do que a situação exigia - tanto melhor se pudesse ser apenas um "sim" ou um "não". Mesmo quando as entrevistas eram longas, mesmo quando eram eles a me procurar para conversar, a sensação que deixavam em mim era de laconismo ${ }^{49}$. As entrevistas acabavam e eu ficava sempre insegura se havia, de fato, conseguido fazer as perguntas certas ou compreender o que eles estavam me dizendo pois a impressão que tinha era de que eles não haviam me dito nada ${ }^{50}$.

Por outro lado, eles também me ofereceram muitas pistas sobre os significados do trabalho e do desemprego, na medida em que a proximidade com a adolescência faz com que observem o mundo a partir de medidas muito rígidas do que é certo ou errado, justo ou injusto. Foram eles que me falaram com mais clareza sobre os esforços que fazem para se diferenciar de outros colegas, retratados como "conformados" com o trabalho manual que lhes sobra.

É possível recolher, em meio a seus relatos, como a opção de continuar procurando ao invés de aceitar os "bicos" traz sofrimentos ao jovem entrevistado, que - principalmente no seio familiar - não escapa do estigma de folgado, que vive às custas da família. Os jovens relataram a tensão constante entre estudar, procurando garantir condições melhores de empregabilidade e o início do trabalho, já que os que parecem estar ao seu alcance são exaustivos, não deixando tempo ou disposição para outras atividades e significando, assim, a perpetuação das condições atuais de vida.

\footnotetext{
${ }^{49}$ Fui procurada por jovens duas vezes. A primeira, logo no primeiro dia de entrevistas. Um jovem de 18 anos, pediu para falar comigo. Na realidade, ele estava acompanhando sua irmã e me procurou para que eu lhe desse "dicas" que o ajudassem a motivá-la para conseguir o primeiro emprego. O outro jovem, de 21 anos, também veio voluntariamente falar comigo, ainda que sua situação fosse diferente dos critérios da pesquisa. Segundo sua explicação, ele queria ajudar de alguma forma - este jovem falou por mais de 40 minutos.

$50 \mathrm{Tal}$ aspecto da relação com os entrevistados jovens está problematizado de modo mais profundo no Capítulo 5, quando trato das histórias de trabalho dos jovens.
} 
Já as mulheres, jovens ou mais velhas, não precisavam de muito estímulo para falar: uma única pergunta rendia alguns minutos de resposta. E foi muito interessante porque, ao contrário dos homens que, quando não entendiam, perguntavam "como assim?", as mulheres logo começavam a responder e, por isso, como é comum e mesmo desejável numa pesquisa de campo, algumas vezes acabei "atirando no que vi e acertando no que não vi".

Uma das dificuldades que encontrei durante o trabalho se deveu ao fato de que a maior parte das entrevistas que fiz foi com pessoas de baixo nível de qualificação e cujas histórias de vida e de trabalho tornam difícil a separação analítica entre as temáticas do desemprego e da pobreza urbana. Desse modo, quando perguntados sobre as razões da desistência da procura, muitos entrevistados responderam imediatamente que "não tinham dinheiro para a condução", ficando impossibilitados de procurar trabalho muito longe de casa. A partir dessa resposta, tão concreta, por vezes ficava difícil chegar a razões de outra natureza que não a falta de dinheiro (e é o caso de pensar se, para algumas pessoas, esse não é mesmo o fator decisivo).

Ao mesmo tempo, como a seleção prévia é feita, em grande medida, a partir da voluntariedade das pessoas se apresentarem, assumindo o seu longo tempo de desemprego e também a interrupção na procura diante do grupo geral que está na fila do Centro, é provável que muitas pessoas, talvez em condições diferentes de escolaridade e renda, deixem de se apresentar como forma de fugir ao estigma. Nesse sentido, essa "falta" se transforma num importante dado sobre os significados diversos que o desemprego pode adquirir, de acordo com a experiência anterior de trabalho.

Outra hipótese para o universo encontrado se relaciona aos dias em que realizei as entrevistas. Quando comecei a fazer as entrevistas, o Centro recebia, de segunda a quarta-feira, mais pessoas com o perfil apontado: pouca escolaridade e especialização, geralmente prestadores de serviço ou jovens em busca do primeiro emprego (fiz as entrevistas mais às segundas e terças-feiras, dias em que mais pessoas se encontravam no Centro). Na quinta e na sexta- 
feira, o perfil dos usuários era um pouco diferente, geralmente pessoas com nível superior que nesses dois dias tinham preferência no atendimento.

Infelizmente, quando voltei a fazer entrevistas, em setembro de 2003, a situação se modificara e essa diferença de público de acordo com os dias da semana deixara de existir . Não foi possível, então, testar a hipótese apresentada acima.

O segundo conjunto de entrevistas realizadas, entre setembro e dezembro de 2003, envolveu um número bem menor de entrevistados: apenas 8. Várias razões contribuíram para isso, a primeira delas já indicada, qual seja, a diminuição do número de usuários do Centro devido à diminuição da capacidade de atendimento.

Outro fator, relacionado àquele, se deve à mudança na forma do atendimento. Atualmente, é feita uma triagem ainda no terceiro andar e algumas pessoas são encaminhadas de lá mesmo. Ainda, a sala na qual eu realizava as entrevistas se transformou em mais um espaço de negociação para conciliação prévia. Ambas as mudanças me obrigaram, então, a rever a estratégia para a identificação de pessoas a serem entrevistadas.

Passei a abordar as pessoas no primeiro andar, pouco antes delas serem atendidas. A sala de espera é bem menor do que a do terceiro andar, comportando em torno de 30 pessoas; lá também existe uma grande televisão. Mais próximas umas das outras e com a perspectiva de serem atendidas em seguida, poucas pessoas se dispuseram a falar comigo. O constrangimento, que já aparecia numa sala de 200 pessoas, ficou maior e as pessoas quase nem olhavam para mim enquanto eu explicava quem era e o que queria.

Dentre esses oito entrevistados, apenas um era jovem (com 18 anos); todos os outros eram mais velhos - acima dos 35 anos. As entrevistas nessa segunda fase foram bem mais curtas e mais focadas na identificação da situação de desalento. Por outro lado, tendo sido realizadas no final do ano, foram 
entrevistas muito doloridas, permeadas pela desesperança que parece atingir os desempregados quando se aproximam as festas de final de $a^{51}$.

\section{Problematizar a condição de pesquisadora}

Quando escolhi o tema da pesquisa de mestrado e o contava para colegas ou amigos, ouvi várias vezes "ah, mas vai ser tão triste”, " cuidado! não vá ficar deprimida..." e conselhos do mesmo tipo, que procuravam me preparar para aquilo que enfrentaria. Eu, de minha parte, se por um lado reconhecia a razão das pessoas, por outro tinha uma certa confiança nas possibilidades abertas pelo encontro e, assim, acreditava que a contribuição que eu teria a dar às pessoas que entrevistaria não seria tanto qualquer improvável impacto de minha dissertação, mas muito mais a escuta atenta de suas narrativas.

Creio ser necessário explicitar, a esta altura do texto, que a maneira com que construí meu problema sociológico, propondo ao desemprego a questão do enraizamento (estreitamente ligado à noção arendtiana de mundanidade), se apóia na crença de que o reconhecimento da própria situação e a partilha desse reconhecimento são condições essenciais para que alguma invenção seja possível. Aliás, a partilha da experiência é o ponto principal, na medida em que é o que possibilita a construção de referenciais comuns e abre espaço para a construção de novas significações para o vivido; para falar nos termos de Hannah Arendt, é o que torna possível a construção de novas medidas.

A crença na importância da escuta das narrativas dos entrevistados se apóia, desse modo, no pressuposto de que elaborar a própria experiência - por meio da palavra e tendo um "outro" como ouvinte - poderia ser uma

\footnotetext{
${ }^{51}$ Quem primeiro chamou minha atenção para essa diferença de disposição entre as pessoas, dependendo da época do ano, foi Ivanir, psicóloga do Centro. Comecei a realização de entrevistas em outubro de 2002 e, ao longo de novembro, ela me relatou que foram aumentando o número de casos de pessoas que choravam durante o atendimento - segundo ela, o "desespero" estava aumentando. Ela também me alertou que tentar fazer entrevistas depois da primeira semana de dezembro seria inútil, pois o Centro fica muito esvaziado. De fato, tentei por alguns dias, mas não encontrava ninguém. Em parte, isso se deve às festas de final de ano; por outro lado, a contratação de temporários também aparece como um fator explicativo.
} 
contribuição às pessoas ${ }^{52}$. Por isso, também, procurei sempre questionar as respostas que eu recebia, desnaturalizando o caráter evidente de que se revestiam, provocando o entrevistado a pensar melhor sobre o assunto. Algumas vezes consegui, muitas outras não.

Em alguns momentos, "coincidentemente" aqueles em que menos via sentido na pesquisa ou nas questões que tentava pensar, a simples perspectiva de ir ao Centro na manhã seguinte me fazia perder o sono. Mais de uma vez cheguei lá, olhei para as pessoas e não senti legitimidade para abordá-las, voltando pelo mesmo caminho por onde tinha vindo. Uma das últimas vezes em que isso aconteceu foi num dia muito frio, uma terça-feira; eu havia chegado bem mais cedo do que de costume, antes das oito da manhã.

Vou ao Centro de trem. Depois que desço na Estação Osasco, passo por um subterrâneo e subo a rua do Centro. Pois bem, naquele dia, desde dois ou três quarteirões antes do prédio comecei a perceber que havia muitos copos plásticos com restos de chocolate quente, bitucas de cigarro, jornais de classificados amassados...Devido ao frio, as pessoas que haviam chegado por volta de cinco da manhã já tinham entrado, embora ainda houvesse fila. Quando subi, várias pessoas estavam lá, assistindo um filme de comédia com o Steve Martin. Não é preciso dizer que não tive coragem nenhuma de fazer pesquisa naquele dia; fiquei pensando "quem sou eu para pedir para alguém que saiu de casa nesse frio, antes das cinco da manhã, que fale sobre sua situação, deixando de lado um filme divertido?".

Claramente, há a necessidade de problematizar esses momentos, procurando transformá-los em objeto de reflexão. Uma das questões-chave pode ser encontrada no relato acima, e reside na minha reação à situação: “quem sou eu para...?”. Como já apontei, essa perda de legitimidade para abordar as pessoas ocorreu concomitante às fases de insegurança em relação à

\footnotetext{
52 Quando procurei novamente as pessoas cujas histórias de trabalho havia escolhido para a análise na dissertação, muitas delas pareceram felizes por terem sido escolhidas, tanto mais porque eu dizia a elas que seriam apenas cinco histórias (conforme o projeto original). Mas o mais interessante acontecia quando, durante a segunda entrevista, elas se davam conta - a partir das novas perguntas - de que eu ouvira, transcrevera e lera a sua primeira entrevista. Todos eles, em algum momento, expressavam sua surpresa: "Mas você leu isso aqui tudo?".
} 
pesquisa como um todo: seu tema, sua importância, sua relevância, a adequação dos termos e dos instrumentos para pensar...Quando perdia de vista o sentido da pesquisa, perdia também o sentido de meu próprio papel, que, ao menos em relação àquelas pessoas, era o único que me autorizava a abordá-las. Ainda que óbvio, é importante notar esse aspecto porque ele revela que, embora meu desejo inicial de "ajudar" as pessoas, ouvindo-as, fosse legítimo, não era ele de maneira nenhuma que dava sentido aos nossos encontros. A pergunta “quem sou eu para...?” só tem uma resposta possível: uma pesquisadora.

Finalmente, essa experiência, que em certo sentido confirma os temores de meus zelosos amigos, é reveladora sobre o lugar que atribuímos ao desempregado e sobre os significados que conferimos ao desemprego: o desemprego aparece aqui como algo a ser tratado privadamente, algo sobre o qual é melhor não falar muito - para não chatear o desempregado, mas também para preservar o "outro", aquele que vai ouvir e não vai saber o que dizer. Há um conjunto de figurações envolvendo o desemprego e o desempregado que determinam a postura daqueles que estão em volta, ainda que tais figurações não sejam sempre as mesmas - assim como os desempregos e os desempregados não constituem um conjunto homogêneo.

Essa é uma hipótese importante para explicar os momentos em que fiquei paralisada: a falta de problematização de minha condição de pesquisadora. Distanciada de meu papel, não me restaram outras formas de aproximação senão aquelas socialmente constituídas e, nesse momento, o pudor e o receio de ferir os sentimentos das pessoas que entrevistaria. Não que a prática de pesquisa possa prescindir desses dois cuidados, mas é preciso reconhecer que se eles conduzem à paralisação, dão notícia de uma forma de entender o outro nesse caso o desempregado - que nos priva a ambos de partilhar nossas experiências.

\section{A seleção das narrativas de trabalho}

Após a realização do primeiro conjunto de entrevistas, examinei diversas vezes os conteúdos das conversas, fazendo anotações, colhendo impressões e, 
um pouco, dando tempo para que as primeiras impressões (registradas no caderno de campo) pudessem ser reexaminadas à distância. $\mathrm{O}$ "banco de histórias" ao qual me referi anteriormente consiste simplesmente na consolidação do material pesquisado, em "fichas" preenchidas à mão para cada um dos entrevistados, contendo anotações sobre sua situação ocupacional e sua trajetória de trabalho a partir da leitura das entrevistas transcritas.

A partir da análise do primeiro conjunto de entrevistas, e também a partir do aprofundamento das questões ligadas ao desemprego e as formas de medilo, decidi pela análise de sete trajetórias de trabalho (duas a mais do que projeto originalmente previa). Os critérios utilizados para a escolha procuraram combinar os dados da PED, relativas ao desemprego oculto pelo desalento e o universo encontrado no trabalho de campo.

Desse modo, optei por trabalhar com três narrativas de adultos, sendo uma trajetória masculina - "típica" - e duas trajetórias femininas. Quanto aos jovens, também optei por trabalhar com uma narrativa feminina e outras três masculinas - ainda que o problema de gênero não aparecesse em suas falas de modo tão marcado, achei que seria interessante preservar a diferença, procurando pensar as trajetórias umas em contraste com as outras, iluminando as questões propostas pela pesquisa a partir de tais contrastes. Como os dados analisados no Capítulo 1 mostraram, o desemprego por desalento se apresenta como fundamentalmente feminino, tratando-se portanto de uma questão que não é possível deixar de lado quando se trata de selecionar as histórias que melhor iluminam o problema.

Decididos os perfis, voltei ao trabalho de campo entre outubro e dezembro de 2003, para encontrar novas pessoas em situação de desalento. Isto porque entendi que não seria fácil entrar em contato com pessoas após o longo tempo decorrido desde a realização do primeiro conjunto de entrevistas. A despeito disso, é interessante notar que apenas um dos entrevistados desse segundo conjunto tem sua história analisada nesta dissertação - José.

Uma hipótese para que isso tenha ocorrido, além do esvaziamento do Centro e da dificuldade de convencer as pessoas a conversarem comigo durante 
esse segundo momento do trabalho de campo, é que - já tendo feito um grande número de entrevistas e estando quase em fase de conclusão do trabalho - meu olhar estava muito mais focado.

De fato, ainda que o objetivo da primeira entrevista sempre tenha sido identificar a situação de desalento, nas primeiras entrevistas eu não tinha tanto "rigidez" quanto aos critérios de classificação e me dispunha a conversar com as pessoas ainda que elas não estivessem em situação de desalento. Assim, abri espaço para descobrir suas histórias e o tipo de vínculo que pude estabelecer com elas foi diferente. No segundo momento, eu acabava conversando mais longamente apenas com pessoas que estivessem em situação de desemprego por desalento - foram apenas duas (de oito).

De todo modo, após "quebrar a cabeça" imaginando como encontrar pessoas nas novas condições de realização da pesquisa, resolvi criar coragem e entrar em contato com as pessoas que havia entrevistado mais longamente na primeira fase, cujas histórias de trabalho eu conhecia melhor. Surpreendentemente (e felizmente), elas se lembravam de mim e concordaram em conceder uma nova entrevista.

Para a segunda entrevista, os roteiros são diferentes para cada entrevistado (conforme Anexos 1.2, 1.3 e 1.4), pois as questões se concentram em torno dos problemas que, a partir da primeira entrevista, eu identificara como os eixos da discussão a ser feita a partir da narrativa. Ou seja, após o exame da primeira entrevista, eu puxava os fios a partir dos quais teceria a análise e, na segunda entrevista, aprofundava as questões que me interessava discutir.

Finalmente, gostaria de notar que não se trata de tomar as narrativas de trabalho analisadas nesse trabalho como "tipos ideais", como se fossem casos exemplares, apenas ilustrativos das diversas situações encontradas. Se a apresentação dos dados da PED e também do universo composto pelo conjunto das entrevistados contribui para a construção de um panorama mais geral acerca da situação de desemprego, a escolha dos sete casos de desemprego por desalento selecionados não foi baseada no entendimento de que seriam 
trajetórias típicas, mas se deu a partir do reconhecimento de que os aspectos do problema que permitiam levantar eram interessantes e contribuíam para o esclarecimento das questões aqui propostas.

\section{Achados de campo}

Seria impossível, ainda que não falte vontade, falar de todos os entrevistados. Cada um narra uma trajetória diferente, contribuindo com a inserção de um novo elemento para o esforço de reflexão dessa pesquisa. $O$ objetivo dessa seção, no entanto, menos que tratar das histórias de trabalho individuais, é construir um panorama, a partir dos relatos dos entrevistados, sobre o mundo do trabalho encontrado. Como já apontei, esse quadro geral orientou a escolha dos casos a serem analisados em profundidade.

Cada um dos entrevistados tem uma voz única: embora, principalmente depois de algum tempo, as entrevistas acabem ficando meio parecidas, na medida em que os problemas enunciados são os mesmos - a idade, a escolaridade, a crise, os políticos, o mundo... - a maneira de enunciá-los é diferente e é por essa razão que me é custoso subsumir os diversos relatos no esforço de fazê-los participar da construção de um panorama geral, como se fossem todos "pedaços" de uma mesma consciência social, só a mim, que concentro mais "pedaços", possível de ser desvendada.

Chamar a atenção para tais aspectos do trabalho de campo está longe de ser apenas "boa consciência sociológica": trata-se de reconhecer algumas das especificidades do trabalho de campo.

O contato com diversas pessoas, a despeito de me mostrar as heterogeneidades das situações que poderiam ser reconhecidas como desemprego por desalento, também me ajudou a formar uma imagem do desemprego hoje - com os temas que suscita, os sofrimentos que a ele se ligam, as aporias com que nos confronta e, principal interesse deste trabalho, as possibilidades que abre.

A apresentação do perfil dos entrevistados ajuda a melhor compreender qual o mundo do trabalho encontrado nesse determinado "espaço amostral" e 
pode, então, contribuir para a relativização dos resultados encontrados na pesquisa e para a formulação de novas perguntas e questões. $O$ universo do desemprego é imenso e heterogêneo; o universo do desemprego formado pelo público que procura emprego no Centro de Solidariedade é, também, heterogêneo. O que pretendo nesse capítulo é esclarecer aspectos do universo do desemprego constituído pelos usuários do Centro que preenchiam os critérios da pesquisa.

\section{O universo dos entrevistados}

No total, foram entrevistadas 34 pessoas, entre outubro de 2002 e janeiro de 2004. Os dados aqui apresentados são a sistematização das informações obtidas na entrevista realizada com as pessoas no Centro de Solidariedade. Como já expus, a entrevista teve como objetivos a identificação da situação de desalento, a verificação de disponibilidade para novas entrevistas e a constituição de um banco de histórias, com informações preliminares sobre o desemprego. Desse modo, ela não tinha entre seus objetivos o preenchimento de nenhum formulário; além disso, o tempo das entrevistas variava, durando de 7 a 40 minutos e, por isso, o volume e a qualidade das informações sobre cada indivíduo não é uniforme.

A despeito dos cuidados tomados na apresentação dos critérios da pesquisa - estar a mais de 12 meses desempregado e haver deixado de procurar durante o período de, pelo menos, um mês - nem a todas as pessoas entrevistadas pode ser atribuída a condição de desemprego oculto por desalento (cf. Capítulo 1). Por essa razão, quando da transcrição da entrevista e levando em conta que se tratava - especialmente quanto ao desemprego por desalento - de classificar uma situação que se referia ao passado, eu chegava a uma conclusão sobre o tipo de desemprego vivido pelo entrevistado. A distribuição dos entrevistados por tipo de desemprego pode ser observada na tabela 6, abaixo. 
Tabela 6 - Entrevistados, por situação ocupacional (em \%)

\begin{tabular}{l|r}
\hline Tipo de Desemprego & \multicolumn{1}{c}{ Total } \\
\hline Desemprego Aberto & 33,3 \\
\hline $\begin{array}{l}\text { Desemprego oculto por trabalho } \\
\text { precário }\end{array}$ & 36,4 \\
\hline Desemprego oculto pelo desalento & 30,3 \\
\hline
\end{tabular}

Quanto ao sexo, houve muito mais entrevistados do sexo masculino do que do sexo feminino. Desse dado, não é possível deduzir que mais homens se encontram na situação de desalento - mesmo porque, como se observa na tabela 6, quase $70 \%$ dos pesquisados não poderiam ser considerados dessa forma. Ao contrário, como a situação em que as entrevistas foram feitas é muito específica, deve-se observar apenas que havia mais homens, de fato, usuários do Centro de Solidariedade e que, geralmente, eles se dispunham mais facilmente a conversar comigo.

Tabela 7 - Entrevistados, por sexo (em \%)

\begin{tabular}{l|r}
\hline \multicolumn{1}{c|}{ Sexo } & \multicolumn{1}{c}{ Total } \\
\hline Feminino & 38,2 \\
\hline Masculino & 61,8 \\
\hline
\end{tabular}

Um aspecto para o qual é importante chamar a atenção pode ser observado na Tabela 8, pois as diferenças de composição do conjunto dos meus entrevistados em relação aos dados da PED ficam evidentes: no grupo de entrevistados, menos mulheres se encontram em desemprego por desalento em relação aos homens. Isso se explica, mais uma vez, pelo local em que as entrevistas foram feitas e pela classificação se referir a uma situação passada. Outra hipótese, mais difícil de ser verificada, leva em conta que as pessoas que experimentam a situação de desalento dificilmente voltam a procurar trabalho. Nesse sentido, é necessário lembrar que as pessoas que encontrei e que haviam vivido a experiência do desalento, encontravam-se num momento posterior, de retorno à situação de desemprego aberto, por ocasião da entrevista. 
Tabela 8 - Entrevistados, por sexo e tipo de desemprego (em \%)

\begin{tabular}{l|r|l|l}
\hline \multirow{2}{*}{} & \multicolumn{3}{|c}{ Tipo de desemprego } \\
\cline { 2 - 5 } & $\begin{array}{l}\text { Desemprego } \\
\text { aberto }\end{array}$ & $\begin{array}{l}\text { Desemprego } \\
\text { oculto por } \\
\text { trabalho } \\
\text { precário }\end{array}$ & $\begin{array}{l}\text { Desemprego } \\
\text { oculto pelo } \\
\text { desalento }\end{array}$ \\
\hline Fexo & 38,5 & 38,5 & 23,1 \\
\hline Masculino & 30,0 & 35,0 & 35,0 \\
\hline
\end{tabular}

Quanto à escolaridade, mais de $30 \%$ das entrevistas não obtiveram declaração sobre o grau de escolaridade. Entre aqueles que declararam escolaridade, é possível dizer que mais de 50\% tinham entre o primeiro grau incompleto e o segundo grau completo. Ou seja, nem analfabetos, nem pessoas altamente escolarizadas - conforme a tabela 9.

Tabela 9 - Entrevistados, por grau de escolaridade (em \%)

\begin{tabular}{l|r}
\hline \multicolumn{1}{c|}{ Escolaridade } & \\
\hline Analfabeto & 5,9 \\
\hline Primeiro grau incompleto & 20,6 \\
\hline Segundo grau incompleto & 2,9 \\
\hline Segundo grau completo & 32,4 \\
\hline Terceiro grau incompleto & 2,9 \\
\hline Terceiro grau completo & 2,9 \\
\hline Sem declaração & 32,4 \\
\hline
\end{tabular}

Ainda, é interessante notar que a escolaridade apareceu como um fator fortemente relacionado à idade. Dentre os 34 entrevistados, apenas dois eram analfabetos - declaradamente, pois não se deve perder de vista o grande número de pessoas que não declararam a escolaridade - e ambos tinham entre 41 e 50 anos.

Quanto àqueles que concluíram o segundo grau, mais de 60\% tinham entre 19 e 30 anos, sendo que 36,4\% tinham entre 19 e 24 anos. A distribuição dos entrevistados por faixa etária pode ser observada na tabela 9, abaixo.

Chama a atenção a concentração em torno da faixa que engloba as pessoas que têm entre 19 e 24 anos - em grande parte constituída por jovens que recém completaram o segundo grau e estão em busca do primeiro emprego - e na 
faixa que inclui pessoas com idade entre 41 e 50 anos. É possível observar que esses são os dois principais públicos atendidos pelo Centro de Solidariedade. Como já observei, desde a primeira vez que fui ao Centro fiquei surpresa e impressionada com a quantidade de jovens que o freqüentavam.

Tabela 10 - Entrevistados, por faixa etária (em \%)

\begin{tabular}{l|r}
\hline \multicolumn{1}{c|}{ Faixa Etária } & \\
\hline De 10 a 18 anos & 2,9 \\
\hline De 19 a 24 anos & 23,5 \\
\hline De 25 a 30 anos & 14,7 \\
\hline De 31 a 35 anos & 5,9 \\
\hline De 36 a 40 anos & 8,8 \\
\hline De 41 a 50 anos & 38,2 \\
\hline Mais de 50 anos & 5,9 \\
\hline
\end{tabular}

Por outro lado, as pessoas mais velhas relatam que o Centro de Solidariedade é um dos únicos lugares aos quais se dirigem para procurar emprego. Na origem desse comportamento está o reconhecimento de que as maneiras de procurar um emprego se modificaram: se antes eles podiam correr à porta das fábricas para conseguir um novo posto, hoje em dia é preciso recorrer à agências de emprego, um lugar que eles reconhecem como operante dos preconceitos em relação à escolaridade e à idade. Muitos também relataram que a ida ao Centro de Solidariedade é uma boa alternativa pois o esforço que se realiza é mínimo - trata-se de um local central e não é preciso preencher fichas (pois são as atendentes que preenchem o cadastro).

Quanto ao local de residência, 94,1\% dos entrevistados reside em Osasco, Barueri ou Carapicuíba. Apenas 5,9\% mora em São Paulo, todos na zona oeste.

Um último ponto que vale a pena descrever se refere ao estado civil dos entrevistados: $44,1 \%$ dos entrevistados eram solteiros, $50 \%$ casados (e ao classificar não distingui entre "amigados" e casamentos civis, ainda que os entrevistados fizessem tal distinção em sua fala) e 5,9\% separados. Entre os casados, procurei investigar a situação ocupacional do cônjuge, conforme a tabela 11. Talvez seja interessante notar que, do que pude observar, os relatos de cônjuges desempregados eram mais comuns entre as mulheres, provocando 
a situação da "família desempregada". Nesses casos, geralmente as dificuldades relatadas eram grandes, permeadas por privações e desafios.

No caso dos homens, notadamente se o tempo de desemprego era longo, as mulheres acabavam sendo empurradas para o mercado de trabalho, pela relativa facilidade com que se empregam em funções femininas, tais como empregadas domésticas, faxineiras, cozinheiras, lavadeiras, enfim toda a gama de funções ligadas à extensão de seus trabalhos domésticos. Nesse caso, o relato do próprio desemprego vinha acompanhado de uma frase de alívio, "graças a Deus que a mulher está trabalhando" ou da ressalva de uma inimaginável condição: "se minha mulher não estivesse trabalhando...".

Tabela 11 - Situação ocupacional dos cônjuges (em \%)

\begin{tabular}{l|r}
\hline $\begin{array}{c}\text { Situação Ocupacional dos } \\
\text { Cônjuges }\end{array}$ & \\
\hline Ocupado & 46,7 \\
\hline Desempregado & 33,3 \\
\hline Aposentado & 20,0 \\
\hline
\end{tabular}

O mundo de trabalho e o universo do desemprego ao qual pertencem os entrevistados pode, agora, ser melhor compreendido. Estamos falando de pessoas de baixa renda: jovens que, tendo concluído o segundo grau, contando para isso com o esforço dos pais, hoje estão em busca do seu primeiro emprego - e suas expectativas se apóiam tanto sobre o valor que reconhecem em seus estudos quanto sobre o reconhecimento de que estes não podem ser interrompidos; mulheres, cujo desemprego do cônjuge, o crescimento dos filhos ou uma separação trouxe de volta ao mercado de trabalho; homens, adultos, cujas profissões desapareceram ou que, tendo construído uma trajetória menos contínua, tornam-se "velhos" para o desempenho de suas funções, no entendimento do mercado de trabalho.

Essas foram as pessoas que encontrei. Mas, para inscrevê-las dessa forma em tais posições sociais, não tomei apenas os dados acima apresentados: em suas representações, na sua forma de compreender o trabalho e de atribuir significação ao desemprego é que tais inscrições ganham mais sentido, contribuindo para iluminar a distinção que interessa fazer, qual seja, entre 
cultura do emprego e cultura do trabalho e também para demarcar os limites e possibilidades de (re)invenção de nossas relações de trabalho - no que diz respeito ao mundo específico dos entrevistados mas também aos outros mundos que revela, uma vez que produz sua identidade à diferença de outras situações.

Os elementos recolhidos no capítulos 1 e neste capítulo 2 contribuem para estabelecer um quadro geral de referência - tanto do mercado de trabalho quanto do universo dos entrevistados. O que parece importante agora é realizar uma análise mais aprofundada sobre os aspectos qualitativos da situação de desemprego por desalento, baseada nas trajetórias específicas de trabalho das histórias selecionadas.

Os capítulos seguintes expõem, assim, sete narrativas; relatos de pessoas que em algum momento de sua trajetória estiveram em situação de desemprego oculto por desalento. A reflexão que se tece a partir de suas histórias de trabalho visa lançar luzes sobre algumas razões do desalento, referindo-as não apenas à conjuntura econômica mas procurando interpretar seus significados no interior de determinadas relações de trabalho, experimentada por cada uma dessas pessoas.

A situação de desalento (a exemplo da categoria desemprego) não é unívoca, e a hipótese deste trabalho é que a desistência da procura a despeito da persistência da vontade de trabalhar - independente do tempo que dure a interrupção da procura - é reveladora de uma crítica que se faz ao mercado de trabalho. Para recuperar a lição de Martins (1998), há uma consciência sociológica da vítima que, quando ouvida e levada em consideração, pode iluminar importantes aspectos acerca do caráter das mudanças que estamos a viver. 


\title{
CAPÍTULO 3 - UMA VIDA DE TRABALHO
}

\begin{abstract}
"A cidade aparece como um todo no qual nenhum desejo é desperdiçado e do qual você faz parte,e, uma vez que aqui se goza tudo o que não se goza em outros lugares, não resta nada além de residir nesse desejo e se satisfazer. Anastácia, cidade enganosa, tem um poder, que às vezes se diz maligno e outras vezes benigno: se você trabalha oito horas por dia como minerador (...) a fadiga que dá forma aos seus desejos toma dos desejos sua forma, e você acha que está se divertindo em Anastácia quando não passa de seu escravo", (Italo Calvino).
\end{abstract}

\section{I - Os caminhos de José}

José tem 52 anos. É casado e pai de duas filhas - uma já casada e outra, de 17 anos, que mora em casa. Branco ${ }^{53}$, de estatura média, usando grandes óculos de grau com lentes escurecidas, José não parece ser de muita conversa.

A primeira entrevista que fiz com ele, em dezembro de 2003, foi bastante curta - menos de 10 minutos. Ainda assim, quando perguntado, respondia às perguntas com tranqüilidade, às vezes rindo, às vezes estranhando um pouco a novidade de ser entrevistado (mas desse estranhamento só vim a saber depois).

Mais tarde, ao transcrever a fita, o tom de seu relato chamou minha atenção. Como apontei no Capítulo 2, no final do ano parece que a dor e a tristeza por não conseguir um emprego aumentam e as entrevistas, em geral, tornam-se mais "lamentosas" (no sentido de se transformarem em uma seqüência de queixas, sem problematização); parece que se enxergam menos possibilidades durante esse período do ano. O relato de José oscilava entre esse

53 A discussão sobre o atributo pessoal "cor" é bastante importante para a compreensão da dinâmica do mercado de trabalho, na medida em que a categoria opera como reveladora de desigualdades de acesso aos postos de trabalho existentes e, assim, sobre diferentes fatores de vulnerabilidade no mercado de trabalho e sobre as representações que interferem na seletividade deste. Entretanto, dada a complexidade e a amplitude das questões que suscita, não é possível tratar do tema, neste trabalho, com a consideração que merece sem danos à discussão central que a pesquisa propôs - quando estava preparando os dados que foram expostos no Capítulo 1, testei trabalhar com os dados relativos à cor e evidenciou-se que eu não poderia explicá-los nem tecer hipóteses sobre o que sugeriam sem abrir novos conjuntos de questões. 
tom de tristeza e o esforço de se manter calmo, em se manter centrado, em reconhecer que sua situação, embora incômoda, não era das piores.

Quando voltamos a nos falar, em janeiro de 2004, ele me fez um monte de perguntas sobre os motivos, o objetivo da realização das entrevistas. Aliás, esse é um aspecto muito interessante de nosso contato - José foi a primeira pessoa que entrevistei que explicitou sua desconfiança ou seu estranhamento em relação às perguntas que eu lhe fazia e, percebendo isso, abri mais espaço para que ele pudesse fazê-lo pois esse estranhamento me foi importante para "mapear" os próprios caminhos das interpretações que eu estava fazendo ${ }^{54}$.

Quando visitei a casa de José para a segunda entrevista, após o término da gravação, ele me ofereceu um café e ficamos lá conversando. Ele brincou que era ele quem estava me entrevistando, pois perguntou quantos anos eu tinha, há quanto tempo era casada, sobre a faculdade, o trabalho e os outros entrevistados. É possível dizer que, com ele, o papel de pesquisadorentrevistador se borrou um pouco, num sentido positivo, pois as dúvidas de José me ofereceram um espelho, mostrando-me inconsistências, equívocos e acertos de minha prática de pesquisa.

Um exemplo disso foi quando, em determinado momento durante a entrevista, ele se deu conta de que eu fizera faculdade ${ }^{55}$. Após essa descoberta, ele passou a relativizar a importância do que estava dizendo e a desconfiar do meu silêncio - que ele deve ter lido na chave de uma mudez condescendente em relação à sua "ignorância". Não demorou muito até que ele dissesse "eu estou vendo que você está estranhando a minha maneira de falar as coisas". Só quando respondi, dizendo a ele com firmeza da importância da experiência de vida e de como os livros não conseguem ensinar a gente sobre isso é que ele relaxou de novo, engatando uma conversa sobre o absurdo das exigências de escolaridade para determinados empregos, para os quais o fundamental é a experiência.

\footnotetext{
${ }^{54}$ Sublinho que ele foi o primeiro a explicitar porque acredito que muitas outras pessoas devem ter tido esse mesmo estranhamento e desconfiança; apenas acharam que não era o caso de questionar.

55 Mesmo eu tendo me apresentado como alguém que estava fazendo um trabalho para a faculdade, ele achou que eu tinha pouca idade e que, portanto, ainda não terminara os estudos.
} 
Esse modo de trazer à tona suas inquietações e de dizê-las de um modo muito delicado, é uma das coisas mais bonitas que José tem. Como me perdi um pouco em seu bairro pois as ruas foram recentemente renomeadas e a população ainda não sabe direito dos novos nomes, José acabou indo me "resgatar" na rua de cima e, assim, chegamos juntos à sua casa. Ao chegarmos, conversamos um pouco sobre o bairro e o transporte, entreguei a ele uma cópia da primeira entrevista que fizera, enfim, ficamos nos reconhecendo um pouco. Mas, em seguida, começamos a entrevista, com o gravador ligado e tudo o mais. Quase meia hora depois, ao responder uma pergunta, ele emenda "Eu estou um pouco meio vermelho porque eu nunca dei entrevista; estou um pouco meio nervoso". Quando foi necessário virar a fita, ele aproveitou para beber água, revelando estar com a boca seca porque nunca antes falara tanto em sua vida. $\mathrm{E}$ ao fim da entrevista, me contou que resolvera falar comigo naquele dia, no Centro de Solidariedade, porque queria me ajudar; afinal, ponderou, não era porque as coisas estavam difíceis para ele que iria deixar de ajudar no que podia - um jeito muito leve de afirmar sua importância e me fazer ver o quanto sua disponibilidade me era necessária para a realização de meu trabalho.

De todo modo, essa introdução visa apenas contextualizar as entrevistas, no esforço de inscrever de alguma maneira a narrativa que se segue no interior de uma história pessoal que, nesse sentido, não pode ser compreendida apenas se tomada como a fala representante de um "perfil social". O que ela tem de revelador se refere aos limites e possibilidades que este sujeito - ainda que circunscrito por sua posição social - é capaz de enxergar, orientando suas decisões e escolhas, identificando possíveis e impossíveis, tanto para si quanto para sua família.

A partir da narrativa de José, aparecem questões relacionadas à constituição de uma trajetória de trabalho descontínua, informada pela facilidade de acesso ao trabalho nos meados dos anos 70, o que trouxe José à situação de, embora tendo trabalhado durante toda a vida, não ter uma profissão. Ligada a este aspecto, a reavaliação de sua trajetória, a partir do 
presente, faz com ele passe a conferir à escolaridade e à qualificação um caráter central na construção da empregabilidade.

A trajetória de José permite, também, a reflexão sobre alguns aspectos ligados ao trabalho, à pobreza e à relação estabelecida com a cidade grande - que ele chama de "lugar das ilusões". A constituição da família e a participação do trabalho feminino no orçamento doméstico como forma de ir conquistando as coisas e melhorando a vida aparece claramente nas suas falas. A consciência de que, para que seja possível constituir alguma coisa, o trabalho de ambos os cônjuges é necessário é uma das fontes de preocupação para José, que sabe que seu longo tempo de desemprego põe em risco as possibilidades de mobilidade de toda a família.

Finalmente, sua condição de pai de duas jovens aliada a sua situação de desemprego, faz com que ele veja o problema do trabalho dos jovens e as perspectivas para suas filhas de uma maneira completamente distinta daquela que têm lugar na entrevista de Fátima (Capítulo 4), por exemplo. Aparece na narrativa de José, mais uma vez, o problema da pobreza e a compreensão do trabalho como a única forma de vivê-la de maneira honesta e digna. Ao mesmo tempo, e transversalmente a todas essas questões, as mudanças do seu mundo do trabalho aparecem com força, tornando possível pensar sobre o tipo de desalento vivido por José.

\section{Trajetória de Trabalho}

Por mais esforços que eu tenha feito para que José me contasse sua trajetória de trabalho ao longo do tempo, provocando-o a se lembrar das datas, do tempo de permanência em cada emprego, do tempo de desemprego após a saída de cada trabalho, o fato é que não conseguimos (nem ele, nem eu) chegar a uma "linha do tempo", delimitando cada uma de suas experiências de trabalho.

É claro que isso se deve menos à alguma falha de memória de José do que à sua noção/compreensão de que as funções que desempenhou não importam em si mesmas, senão para a constituição de sua identidade de pai de família 
responsável. Como ele mesmo disse ao final da primeira entrevista: "Mas o que dificulta mais para mim conseguir um emprego é a idade; a idade e a profissão, que eu não tenho. Se eu tivesse uma profissão, talvez hoje fosse mais fácil. (...) eu sempre trabalhei em fábrica, aprendia e depois o que eu aprendia ficava ali...Nunca pude aprender assim uma profissão definida, que você sai do emprego e você encontra ela em outro lugar. Isso aí eu não consegui". Em sua vida de trabalho, José desempenhou funções, sem acumular a experiência ou a qualificação que lhe possibilitassem a aprendizagem de uma profissão definida. Como se verá mais adiante, o critério que contava para a escolha de seus trabalhos era sobretudo a remuneração ou a escolha de melhores condições de trabalho.

Há, ainda, nessa fala um aspecto muito importante, que é revelador do mundo do trabalho no qual José se localiza: o tipo de trabalho que realiza, pesado e "geral", é um trabalho que se consome no fazer. Se quisermos falar nos termos arendtianos, é quase puro labor. As funções que desempenha não the conferem uma identidade profissional e não produzem nada que dure mais do que o tempo do fazer.

É claro que se trata de uma afirmação exagerada: como venho argumentando, as relações com o trabalho têm uma importante dimensão simbólica e moral, estejam elas mediadas pelos valores que fazem parte da cultura do emprego ou da cultura do trabalho. O que pretendo sublinhar aqui é que o modo pelo qual José se insere no mercado de trabalho, tendo o presente como medida e como horizonte (já que se trata de necessidades imediatas) transforma sua trajetória de trabalho num conjunto de experiências encerradas em si mesmas: o que ele aprendeu, deixa na empresa e, nesse processo, ao invés de ir constituindo uma identidade profissional, ele a perde pois vai "gastando" os atributos que o inserem (sua força física, sua disposição em transitar pelo mercado a procura de salários melhores...). É, então, no intuito de sublinhar tal dilapidação que essa afirmação hiperbólica deve ser compreendida.

José sai das empresas na mesma condição em que entrou, sem que se acumulem conhecimentos ou experiências capazes de transformar a sua posição no mundo do trabalho: ele é um pai de família, responsável, que trabalha para 
cumprir seus compromissos e, nesse sentido, é um trabalhador. Mas é um trabalhador sem profissão, desempenhando diferentes funções, quando houver funções a serem desempenhadas ${ }^{56}$. Voltarei a isso.

Em relação às diferenças entre um pai de família responsável e um trabalhador, ouvi a seguinte preleção de um motorista ao cobrador, numa viagem de ônibus, que recupero aqui porque revela lados importantes da questão exposta acima: “Olha, eu sempre peguei o ultimo horário. Não por gosto, mas por política da empresa... Tudo bem, a gente ganha um dinheiro a mais; mas se o trabalho de oito horas pagasse o suficiente, eu não trabalharia 12 horas. Porque as pessoas falam do trabalhador. Mas trabalhador, quando o cara é trabalhador mesmo, no fim-de-semana, domingão, ele sai com pá, enxada e carrinho para trabalhar sem ganhar nada. Você faz isso? Nem ganhando está fazendo...O trabalhador é quem gosta de trabalho. Agora, a pessoa responsável, o pai de família, esse trabalha porque precisa...". Essa fala é muito interessante, pois distingue entre uma ética do trabalho, que transparece no gosto pelo trabalho, e uma ética de outro tipo, relacionada à família e aos compromissos com ela assumidos. Como a fala do motorista mostra, o trabalho excessivo do trabalhador nada tem a ver com o gosto pelo trabalho, mas sim com a insuficiência dos ganhos deste para sustentar uma família. É a necessidade, portanto, e não o gosto, que leva ao trabalho constante e excessivo. E o seu esforço por distinguir esses dois tipos de trabalhador revela a compreensão de que se trata de uma situação social produzida por uma injustiça fundamental, que é a da insuficiência dos rendimentos do trabalho, insuficiente para a sobrevivência material, mas também sobrevivência de um modo de vida - quem tem na família seu eixo principal. Essa situação empurra, então, as pessoas responsáveis à aceitação de trabalhos extras, de mais trabalho ${ }^{57}$. A fala do motorista revela ainda que não é a remuneração o principal no

\footnotetext{
56 É muito importante esclarecer que o uso da palavra função não está relacionada, nessa análise, a um tipo de compreensão funcionalista da dinâmica do trabalho. A palavra, no sentido aqui utilizado, estabelece seus significados quando contraposta à idéia de profissão e às práticas que a definem.

${ }^{57}$ Essa qualidade moral que impele à assunção das responsabilidades sobre a própria vida por meio de um comportamento diligente será retomada ao longo do trabalho, notadamente a partir do relato de Fátima, exposto no capítulo seguinte.
} 
trabalho que se realiza por gosto; por outro lado, no trabalho que se realiza por necessidade, sua objetividade, ou seja, a função desempenhada, não tem importância, contanto que assegure o salário ao fim do mês ${ }^{58}$.

Outro aspecto que vale a pena ressaltar é a capacidade de análise em relação aos significados do trabalho demonstrada pelo motorista, bastante diferente da dificuldade expressada por José, que nesse momento de desemprego prolongado, olha o passado para se culpar por não ter adotado outras estratégias, sem parecer se dar conta da dimensão da exploração e da injustiça que sempre caracterizaram sua trajetória ${ }^{59}$.

A ética do trabalho apresentada pelo motorista é bastante parecida com aquela que a trajetória de José expressa: o que confere sentido ao trabalho é o sentimento de responsabilidade familiar. Esse aspecto, fundamental para a compreensão da trajetória de José, será retomado no decorrer do capítulo.

José chegou a São Paulo em 1973, aos 23 anos. Antes disso, morava no Paraná, numa cidade chamada Paraíso do Norte e trabalhava na roça, com os pais e os irmãos. Sua irmã já morava aqui e, por isso, ele veio para ficar com ela por algum tempo. Em seguida, vieram os pais e os irmãos que, na época, ainda moravam com os pais (o próprio José, dois homens e duas mulheres).

Depois de mais ou menos quatro meses que estava em São Paulo, ele conseguiu o seu primeiro emprego, registrado, como ajudante geral, numa pequena fábrica de plástico, na Avenida Santo Amaro (zona sul de São Paulo). Trabalhou lá durante 11 meses e resolveu sair, para procurar um emprego cuja remuneração fosse melhor. Ficou quatro meses desempregado antes de conseguir um novo trabalho, também registrado, numa tapeçaria e tecelagem.

\footnotetext{
58 No capítulo 5, sobre experiências dos jovens, a distinção entre o trabalho que traz realização pessoal e aquele que se pode realizar aparece com bastante força: algumas vezes operando como impulso para o início do trabalho, outras operando como fator de desalento, devido à falta de possibilidades enxergadas. De todo modo, vários autores que trabalham com juventude têm mostrado que a "recusa ao trabalho" é, muitas vezes, recusa ao trabalho esvaziado de sentido em si mesmo, pois para esses jovens, a constituição da família ou o sustento dos filhos não estão no horizonte próximo o suficiente para mediar a relação deles com o trabalho. Ver, por exemplo, Bajoit e Franssen (1997) e Chiesi e Martinelli (1997).

${ }^{59}$ Para uma análise muito interessante acerca das diferentes estruturas cognitivas ao alcance dos trabalhadores, segundo sua própria experiência de trabalho na cidade, ver Rodrigues, 1978.
} 
Nessa tapeçaria ficou mais ou menos sete meses, saindo de lá para entrar, já em 1975, numa outra fábrica de plástico.

No relato de José, o período que vai de 1975 até 1992 fica bastante nebuloso. Em outros momentos da entrevista, ele mencionou ter trabalhado em muitas fábricas e empresas grandes - "Todos esses empregos foram em fábrica, todos. Tudo foi em fábrica: fábrica de plástico, tecelagem, metalúrgica, fábrica de brinquedo, cooperativa - mexia com alimento, que foi na Cooperativa Agrícola de Cotia - depois passei a trabalhar em depósito, não é? Como no depósito da Casas Centro, da Ponto Frio. Quase todos esses empregos meus foi em fábrica mesmo, até 90 foi só em fábrica mesmo; até os anos 90 foi só em fábrica" -, mas foi impossível precisar os anos de entrada e de saída. É interessante notar que, ainda que nem todos os trabalhos tenham sido realmente em fábrica, como as atividades desempenhadas eram parecidas, ele coloca todos no mesmo rol de "trabalhos em fábrica". Uma outra interpretação possível é que ele esteja identificando o trabalho registrado ao trabalho em fábricas e empresas grandes, diferenciando em qualidade estes vínculos em relação àqueles que encontra mais recentemente.

Até o início dos anos 90, essa trajetória - embora cheia de interrupções era uma trajetória contínua, pois José saía de um emprego com a certeza de que encontraria outro. As interrupções aparecem também em relação ao registro em carteira. José disse que sempre trabalhou registrado, mas, na primeira entrevista, ao descrever sua trajetória desde a chegada a São Paulo, narrou: "comecei a trabalhar registrado com 23 anos, antes disso, até os 23 anos eu não morava aqui em São Paulo, morava no Paraná, trabalhava na roça. Trabalhava como agricultor, trabalhava com minha família. Aí depois, com 22 anos eu vim aqui para São Paulo, $e$ com 23 anos eu já comecei a trabalhar registrado. De lá até um ano atrás eu trabalhei registrado; mas nesse tempo aí teve época em que eu fiquei parado também, fiquei trabalhando sem registro, trabalhei lá no centro também sem registrar".

Como já apontado por outros trabalhos (Guimarães, Hirata, Montagner e Watanabe, 2003; Guimarães, 2004), o desemprego, para muitos trabalhadores como José, era parte integrante de sua condição de trabalhador, caracterizando 
uma trajetória estruturada a partir da recorrência do emprego. Ademais, como fica claro na fala de José, raramente a saída do emprego se dava por demissão ou falência da empresa, mas se tratava de uma decisão com vistas a melhorar o rendimento, num novo emprego, melhor ${ }^{60}$.

Entre 1975 e 1992, José trabalhou na fábrica de brinquedos Estrela, em uma metalúrgica, na Cooperativa Agrícola de COTIA "e outras firmas que não é nome famoso".

Em 92, José parou de trabalhar em fábricas, entrando num depósito da Casa Centro, sempre no cargo de ajudante. Ficou lá um ano e meio, saindo em 1993. Desse emprego, José pediu para ser mandando embora: “Eu trabalhava na Casa Centro, aí fui mandado embora...Não é que eu fui mandado embora: eu pedi para mandar embora porque eu estava trabalhando à noite e não estava lidando bem trabalhando à noite".

Depois disso, ficou nove meses desempregado, conseguindo outro emprego em depósito em 1994, também como ajudante. Em 1996, três anos após sua entrada, passou a ser conferente - o que significou um aumento de quase 100\% em seu salário. Ficou mais dois anos no Ponto Frio, até ser dispensado.

Cinco anos, o tempo que permaneceu trabalhando no Ponto Frio, foi o máximo de tempo que permaneceu em uma mesma empresa. Ao longo de toda a sua trajetória, ele calcula ter trabalhado em, mais ou menos, dezoito empresas: "acho que umas dezessete ou dezoito, exatamente. O máximo que eu fiquei numa empresa foi cinco anos, que foi essa que eu trabalhei no Ponto Frio, né? O resto foi quatro anos, dois anos, três anos, um ano, seis meses, três meses, um mês...". Nas próximas seções, darei atenção especial à esta característica da trajetória de José, a partir da análise que ele mesmo faz de sua atual situação.

\footnotetext{
${ }^{60}$ É interessante notar que a Consolidação das Leis de Trabalho no Brasil não parece ter sido suficiente para ordenar o mercado de trabalho, pelo menos não no sentido de fixar os trabalhadores a empregos mais duradouros. De fato, como mostra Annez Troyano, mesmo os trabalhos assalariados se caracterizavam pela rotatividade - que tanto assumia o caráter de gestão empresarial, quanto o de como estratégia dos trabalhadores. Assim, os estímulos à continuidade do contrato de trabalho, constituídos pela legislação trabalhista, não funcionavam na prática: os custos de demissão eram relativamente baixos e o resgate do FGTS muitas vezes se constituía num estímulo maior do que a permanência no emprego. Sobre a flexibilidade das relações de trabalho, ver Troyano, 1991.
} 
Após a saída do Ponto Frio, em 1998, é difícil precisar quanto tempo José ficou desempregado: ao longo da entrevista, esse tempo variou entre três e seis meses, uma imprecisão que revela que - no seu modo de entender - naquele momento as coisas ainda estavam mais ou menos fáceis, já que esse intervalo "de três a seis meses" costumava ser o intervalo normal entre dois empregos.

Em 1998, por indicação de sua cunhada, começou a trabalhar como bilheteiro: "quando eu saí do Ponto Frio, eu não cheguei nem a procurar, porque quando eu saí do Ponto Frio, eu fiquei uns...quase seis meses desempregado. Fiquei quase o mesmo tempo que eu fiquei quando eu saí dessa em que eu estava, né?61 Aí, de repente, a minha cunhada trabalhava numa empresa na Avenida Paulista, aí falou para mim desse serviço que eu trabalhei, né? Que estava...tinha essa empresa que ia abrir uns terminais de ônibus e as pessoas iam trabalhar vendendo passe de ônibus, passe escolar, de metrô, essas coisas e se eu não queria ir lá e tentar. Inclusive ela trabalhava nessa empresa. Aí ela deu uma força para mim e foi tudo fácil para mim, né? Com a ajuda dela foi tudo fácil; do dia para a noite eu já entrei e comecei a trabalhar nesse emprego; e trabalhei quatro anos, né?".

Após sair desse emprego, do qual foi dispensado porque a empresa passou a enfrentar problemas financeiros, José não encontrou um novo posto. Desde 1 de agosto de 2002, está desempregado:

"Aí quando saí de lá (do Ponto Frio), fiquei uns três ou quatro meses desempregado62, e entrei nessa outra empresa em que eu estava, (como) auxiliar de bilheteria, um... tipo assim aquele pessoal que vende (bilhete) de metrô e trem, que tem o pessoal que vende o bilhetinho lá dentro e o pessoal chega, compra a passagem. Eu trabalhava naquele tipo de serviço, um serviço bom, eu trabalhava sentado, mexendo com dinheiro o tempo inteiro. Nessa empresa trabalhei quatro anos e aí me mandaram embora (...) depois eu perguntei qual era o motivo, eles não quiseram explicar, falou que apenas tinha que cortar porque a empresa estava em dificuldade... (...) foram mandadas

61 José se refere aqui ao último emprego, em que trabalhou como bilheteiro. Segundo me relatou, José não começou a procurar emprego logo depois de tê-lo perdido. Esperou seis meses, contando com o benefício do seguro-desemprego e a indenização. Durante esse período, realizava pequenas reformas na casa.

${ }^{62}$ Como já apontei, a imprecisão sobre datas e durações de desemprego foi constante na narrativa de José, revelando um certo "descuidado" que pode ser creditado à segurança de conhecer a dinâmica e os mecanismos do mercado de trabalho. 
embora mais duas pessoas, comigo três, na época em que saí e de lá para cá não arrumei mais nada".

É preciso reconhecer que não se pode classificar, pelo menos a partir de critérios objetivos, todo este seu último período de não-trabalho como desemprego - pelo menos de desemprego aberto. Nos primeiros seis meses após a perda do emprego, José não procurou (essa não procura no momento imediatamente posterior à perda do emprego parecia uma prática comum aos seus outros períodos de desemprego, sendo o tempo aproveitado para fazer pequenos consertos na casa), dizendo que "se aparecesse" alguma coisa, começaria a trabalhar, mas sem sair para procurar. A partir de janeiro de 2003, começa a procurar, numa situação clara de desemprego aberto. Em meados de junho ou julho, devido às dificuldades enfrentadas, resolveu parar de procurar a fim de esfriar a cabeça, voltando a procurar em outubro de 2003. Quando realizei a segunda entrevista, em janeiro de 2004, ele havia novamente parado de procurar.

Do ponto de vista subjetivo, no entanto, José está mais desempregado que nunca, pois se trata do maior período em que já ficou sem ter trabalho e sem ter, também, a perspectiva de encontrar trabalho - tudo está difícil para ele: "Quando foi seis meses que eu estava desempregado, eu comecei a procurar, foi mais ou menos em janeiro do ano passado que eu comecei a procurar emprego. De lá até agora eu sempre tenho procurado, às vezes tem época em que eu paro de procurar, eu comecei a procurar em janeiro do ano passado e quando foi em maio, maio e junho eu dei uma parada, um pouco meio desanimado, pensei, eu estava achando que não ia conseguir mais nada, aí fiquei parado uns três ou quatro meses sem procurar. E aí voltei a procurar de novo e agora eu continuo procurando mas está difícil, eu não consigo nada".

Esse período último de desemprego, portanto, é diferente dos tempos de desemprego anteriores. Antes, ainda que demorasse mais ou menos, José podia contar que um novo trabalho apareceria, bastando que ele procurasse. Atualmente, para além da situação mais geral, sua idade e pouca escolaridade, aliadas ao fato dele não ter uma profissão definida aparecem como fatores que dificultam seu retorno ao mercado de trabalho. 
Última observação, antes de passar à discussão dos diferentes aspectos levantados a partir da trajetória de José: é importante sublinhar a presença que o desemprego tem ao longo de toda a sua trajetória. Logo na primeira entrevista, ele destacou que, durante seu tempo de trabalho, ficou uns tempos parado, outros trabalhando sem registro. É ele quem chama a atenção para esses constantes "desvios" ao longo do caminho. Ao mesmo tempo, como já assinalei, esses desempregos, que ocorriam antes, faziam parte do jogo: eles eram o preço a se pagar pela vontade de melhorar o salário ou as condições de trabalho. Antes, o desemprego não era um problema tão grave quanto é hoje e esse corte temporal realizado por José é revelador do olhar crítico que dirige ao momento atual.

Assim, não é que antes sua situação fosse mais estável: era a facilidade do trânsito pelo mercado de trabalho e entre situações formais/informais que minorava os danos da precariedade dos vínculos. No presente, porém, a instabilidade que sempre caracterizara a trajetória de José, aparece de modo mais visível e se expressa em sua consciência clara de que não houve nenhum acúmulo - para além das conquistas possibilitadas pelo trabalho em conjunto com a esposa. E é importante notar que tais conquistas não resultaram de estratégias orientadas para o futuro, mas sim de conquistas possibilitadas pelas "sobras" do trabalho (e, como se verá mais adiante, não à toa, tais "sobras" só são possíveis quando, ao trabalho e ao rendimento do "provedor", junta-se o trabalhinho e o salarinho da mulher) - aquilo que, embora necessário, não deixa de ser em certa medida supérfluo à sobrevivência.

\section{A cidade $e$ as ilusões}

A migração para São Paulo e as possibilidades abertas pelo fato de morar na cidade grande estão sempre presentes na fala de José e a avaliação que faz, distinguindo o momento em que chegou aqui em relação ao presente, dá notícia de importantes deslocamentos, ocorridos não apenas no mundo do trabalho mas também na relação das pessoas com a cidade. 
Quando perguntei a José o que ele esperava ao vir para São Paulo, se já planejava, então, estabelecer-se aqui, constituir uma família, etc., ele respondeu que não, que sua maior preocupação era saber se conseguiria se adaptar à cidade, tão diferente da vida que levava morando no interior. A adaptação se fez por meio do trabalho e da sociabilidade criada por ele:

"quando eu vim para cá logo nos primeiros dias eu não pensava isso (em casar, ter filhos)...Minha preocupação, quando eu vim morar aqui em São Paulo era se eu ia me acostumar ou não. Mas isso aí não demorou muito tempo, acho que menos de um mês que estava aqui eu pensei que eu ia...ia me dar bem aqui, aprendi a gostar daqui. (...) justamente depois que eu comecei a trabalhar, aí comecei a fazer amizade com os colegas de trabalho, no final de semana ia passear, ia nalgum bailinho, essas coisas, né? Aí foi quando eu comecei já a sentir que eu comecei a gostar daqui, então mesmo eu comecei a gostar daqui e esqueci já do interior".

Quanto às expectativas que tinha, José avalia que elas estavam relacionadas com as narrativas dos parentes e amigos que vinham para São Paulo e voltavam falando maravilhas, contando histórias que marcavam uma diferença radical em relação à vida no interior (e a idéia de "interior", na fala de José, está sempre associada ao meio rural):

"Ah, todo mundo que vem aqui para São Paulo, principalmente naquela época, acho que tinha aquela ilusão, né? Pessoas, parece que morava aqui e ia passear lá e falava que aqui era bom; é mais também essa ilusão que a gente tinha, né?" 63 .

Perguntei a ele que "ilusão" era essa e sua resposta fala da dinâmica da cidade, regida por uma lógica inteiramente diferente da ordem da vida que se leva no interior. A imagem que ele usa - aqui tudo é festa - fala da constante

\footnotetext{
${ }^{63}$ Arakci Martins Rodrigues, analisando os resultados de sua pesquisa de campo com operárias e operários, em 1976, conclui que “...essa população é antes expulsa de seu local de origem do que atraída pelo local de chegada. Mesmo nos casos em que migra porque São Paulo é um lugar melhor para se viver, as informações sobre a capital que chegam até ela são fragmentárias e simplistas. Basicamente, o que surge de novo no universo mental dos indivíduos são fragmentos do tipo 'Em São Paulo tem mais emprego'; 'Em São Paulo a gente ganha dinheiro'. Como salienta E. Durhan, embora conseguindo prover às necessidades alimentares da família através da produção agrícola, o dinheiro é difícil e raro na agricultura de subsistência. Isso talvez explique o tratamento que alguns entrevistados dão à categoria 'dinheiro'", (Rodrigues, 1978, p.100-1).
} 
ruptura da ordem conhecida, das inversões dos lugares e do ritmo da cidade, que transforma o migrante que aqui permanece:

"Porque aqui tudo é... Aqui em São Paulo tudo é vaidade; o pessoal do interior não conhece como que é aqui, quando chega aqui...Por isso que, quando a gente vem do interior, as pessoas mudam aqui, né? Porque aqui tudo é festa, tudo é...Não sei se hoje ainda é assim, não consigo perceber não, mas quando eu vim para cá, era assim, né? (...) ilusão assim, a gente pensa que a gente vai ganhar muito dinheiro, que vai ter aquilo e, no fim, não é nada disso que a gente pensa, né? Que (a gente) consegue. Justamente diferente do interior, cada um tinha sua casa no interior. Parece que as pessoas aqui têm mais sonhos, têm mais...Quero dizer, é, tem mais sonhos,né? Lá no interior o pessoal é...Tem um pessoal parado, lá eles só sabem que eles tem que trabalhar o dia e dormir a noite. E mais nada, né?"

O problema do lugar social e do desterro se coloca - cada um tinha sua casa -, reforçando as análises que vêem no espaço da casa e na conquista da casa própria o sonho maior das famílias, em torno do qual se articulam as estratégias de sobrevivência e de trabalho e, principalmente, em torno do qual se articula o universo simbólico da pobreza ${ }^{64}$. Ao mesmo tempo, a ampliação daquilo que se pensa como possível insere novos sonhos, novas vontades na vida das pessoas, subvertendo a ordem da vida, expressa no "trabalhar o dia e dormir a noite". As ações possíveis sobre o tempo no universo do "interior", pelo menos como aparecem na fala de José, são as ações naturais, trabalhar e dormir, dormir e trabalhar, no sempre mesmo dos dias.

Na cidade isso se modifica radicalmente:

"Então, a gente vem para cá, a gente começa a ter sonho, vê tanta gente bem de vida, a gente começa a querer ficar bem também. É uma ilu...Quer dizer, é um tipo de uma ilusão, que a gente tem. Muita gente consegue chegar lá e muitos não conseguem".

Reconhecendo que algumas pessoas conseguem realizar seus sonhos, enquanto algumas outras não conseguem, José relativiza o peso da "ilusão" que 
atribui a vida da cidade e, assim, mostra que, em alguns casos, as ilusões se mostraram possibilidades reais ${ }^{65}$.

José até tentou voltar para o interior do Paraná, bem no início dos anos 80, quando ainda era solteiro, mas não se adaptou:

"Então eu tentei voltar para lá, fiquei lá um bom tempo, fiquei aproximadamente pouco mais de um ano. Mas durante esse um ano que eu fiquei lá - trabalhando com parente, né? Tinha uns parentes que mexiam com restaurante lá...Eu fui lá para passear mas acabei ficando lá um bom tempo, aí não quis saber mais de trabalhar em São Paulo, fiquei trabalhando com eles lá. Só que eu ficava dois, três meses lá e voltava aqui para São Paulo, ficava uma semana, duas semanas, não queria trabalhar aqui e voltava para lá de novo; ficava uns dias lá e voltava para cá de novo. Aí chegou uma hora em que eu tinha que escolher: ou ficava lá ou ficava aqui, como eu gostava mais daqui, fiquei aqui. Então, é bom aqui em São Paulo, eu gosto muito daqui; acostumei aqui, para mim não tem um outro lugar. Mesmo sendo esse inferno que é, eu gosto daqui. Se eu tiver que sair daqui, não consigo mais não. E eu gostava do interior, quando eu morava lá eu gostava, pensava que não ia me acostumar aqui, mas depois que eu vim para cá eu acostumei, não gosto mais (do interior)".

Resumindo suas expectativas em relação à vinda para a cidade, José põe no centro da decisão as características próprias da juventude, lançando um olhar retrospectivo e reconhecendo, nesse movimento, o sentido da aventura presente na migração, bem como uma certa ingenuidade em confiar que tudo daria certo:

"É meio difícil de eu tentar te explicar sobre isso aí, mas eu vou tentar falar alguma coisa para você. O sonho que eu tinha - só, não sei se você já passou por essa fase ou está passando ainda, né? - todo jovem tem aquele sonho, tem aquela sensação de que está tudo bem, que não existe problema, que as coisas é tudo às mil maravilhas. $O$

65 Sobre a representação da cidade como cenário da realização dos sonhos, foi bastante interessante observar as falas e as imagens que emergiram nas comemorações dos 450 anos da cidade de São Paulo, em janeiro de 2004. Muito se falou sobre a heterogeneidade da população, composta por migrantes de diversas regiões do país e do mundo, mas, nas histórias escolhidas, enfatizou-se que a acolhida que a cidade ofereceu às pessoas esteve sempre mediada pelo trabalho e houve uma preocupação em mostrar os frutos do trabalho: os filhos e filhas que lograram uma mobilidade ascendente, através do estudo e, é claro, do trabalho. O que parece vincular esses migrantes à cidade, além dos laços que estabeleceram, é um sentimento de gratidão pelas oportunidades que ela ofereceu. 
que eu pensava mais era isso, que eu viria para cá, que eu ia trabalhar, que eu ia ganhar dinheiro, que eu ia me divertir, é só isso!".

É interessante notar a simplicidade do sonho: chegar, trabalhar, ganhar dinheiro, divertir-se... Ou seja: o sonho era o de viver sem grandes sobressaltos; não se tratava de imaginar uma rápida e notável ascensão social. Mesmo a imaginação estava delimitada pelas possibilidade de ganho do trabalho; se tudo corresse bem, por meio do trabalho seria possível alcançar alguma estabilidade. Ao analisar as suas próprias conquistas, José acredita ter conseguido algumas coisas:

"Eu acho que eu consegui alguma coisinha. Porque eu vim aqui para São Paulo, eu vim apenas com duas calças, duas camisas e o dinheiro da passagem. Cheguei aqui, comecei a trabalhar. Era para ter melhorado bem antes, mas eu não me interessei, né? Vim a melhorar mais a minha situação depois que eu casei. Quando eu casei eu não tinha nem uma casa para morar, ainda pagava aluguel. E consegui a minha casa, minha casinha. E outros que veio na época e até hoje estão no aluguel ainda? Acho que eu consegui alguma coisinha. Não consegui o que eu queria, exatamente o que eu queria, mas pelo menos um lugarzinho para a gente ficar a gente tem, não é?".

Nessa fala, que será retomada na próxima seção, José revela a importância da família, que insere outros critérios e valores que orientam as estratégias de trânsito no mercado de trabalho. A conquista da casa e a independência em relação ao aluguel são valorizados como uma importante melhoria de vida, que possibilita que os rendimentos não sejam desperdiçados no aluguel e que garante que, aconteça o que acontecer, ele e sua família terão um lugar - o que não deixa de ser uma forma de deitar raízes no solo da cidade ${ }^{66}$.

Essas conquistas, na avaliação de José, só foram possíveis devido ao momento específico em que chegou a São Paulo:

${ }^{66}$ Éclea Bosi, tratando das mudanças experimentadas pelos migrantes quando de sua vinda para a cidade, recupera algumas falas, que giram em torno da ausência de um solo para plantar e o conseqüente medo da fome (Bosi, 1987); a casa própria aparece então como esperança de conquista de um novo lugar e também esperança de garantir a sobrevivência (afinal, não precisar pagar aluguel confere aos trabalhadores uma garantia de permanência ainda que estejam desempregados). 
"E sobre o fato das pessoas virem aqui para São Paulo, como eu te falei ainda agora, que seria mais uma ilusão, na época em que eu vim - acho que até hoje continua a mesma coisa, quem vem de lá para cá. Só que naquela época em que eu vim, as coisas eu acho - as coisas eram bem mais fácil. Tinha emprego para todo mundo, hoje em dia, hoje não está mais assim, as pessoas que vierem para cá vão ter mais dificuldades, a não ser que seja uma pessoa que vem preparada. Como, por exemplo, eu quando vim para cá, eu vim totalmente despreparado, para emprego. Mas como era fácil, como tinha muito emprego naquela época, então...Para mim não foi difícil. Mas se eu tivesse vindo na situação, hoje, na situação que eu vim naquela época, se eu tivesse vindo agora, nessa época eu tenho certeza que eu não ia encontrar...As coisas não seriam tão fáceis para mim como foi aquela época, porque eu vim despreparado, né? Apesar que eu era novo, e as pessoas novas, quando a gente é novo as pessoas sempre conseguem, sempre arrumam alguma coisa para fazer, mas eu não vim preparado para o mercado de trabalho, que eu acho que quando a gente está preparado para o mercado de trabalho é quando a gente estuda, que a gente faz cursos, pelo menos um colegial completo, coisas que eu não tinha quando eu vim para cá".

As mudanças, ocorridas em menos de 30 anos, aparecem claramente nessa análise da situação. Antigamente, as possibilidades eram maiores, bastando a vontade de procurar - era o tempo da abundância de empregos e oportunidades (um tempo sobre o qual se alicerça uma idealização do passado, presente na fala dos trabalhadores mais velhos e também dos jovens, que estão iniciando sua carreira profissional). Hoje em dia é diferente, as exigências são maiores, não é mais possível se aventurar a vir para a cidade antes de estar preparado.

Ainda sobre essa fala, impressiona o impacto que esta nova experiência de desemprego tem sobre as perspectivas enxergadas por José, pois ao dizer que se tivesse vindo hoje com certeza não encontraria um trabalho, José está, novamente, a tecer uma crítica às suas estratégias de trânsito pelo mercado de trabalho, que não possibilitaram acúmulo de conhecimentos e experiências. É também essa percepção que aparece na preocupação que demonstra em relação à filha mais velha, que abandonou os estudos e se torna uma espécie de espelho, no qual José projeta suas dificuldades atuais e a interpretação sobre suas razões - sem se esforçar para constituir uma identidade mais duradoura, 
sem preparar-se para o mercado de trabalho, a filha se arrisca à vida difícil que o pai imagina que teria sido a sua, caso tivesse chegado à cidade no momento atual.

Mais uma vez, reafirma-se a íntima relação entre a cidade e o trabalho: é a possibilidade ou não de trabalhar que determina as condições de enraizamento na cidade. É por meio do trabalho que, na cidade, constrói-se um lugar. Agora, porém, é preciso preparar-se, estudando, fazendo cursos, no esforço de garantir, de algum modo, que as coisas não sejam tão difíceis. E qual é o parâmetro dessa dificuldade? A experiência desse novo tipo de desemprego; novo em relação àquele que se conhecia, aquele que era um tempo de transição, no qual o horizonte de um novo trabalho estava presente. Como a fala de José diversas vezes mostra, esse horizonte está se dissipando, a situação nunca esteve tão ruim como hoje, e não há perspectivas de melhora.

As razões às quais imputa o desemprego também estão relacionadas à cidade - e são percebidas pela observação do movimento urbano: "o que eu acho é que tem muita gente para pouco emprego, né? Porque você vê que todo mundo corre aqui para São Paulo, você sai - se você for às seis horas lá no centro da cidade, você não consegue andar no centro da cidade de tanta gente. Onde que vai ter emprego para todo mundo? Eu acho que é isso mesmo; eu acredito que está sendo difícil por isso aí, porque tem muita gente, acho que não tem emprego para todo mundo".

A cidade, a atração que exerce ainda hoje sobre as pessoas "do interior", interessadas numa vida melhor, acaba encontrando os seus limites - não é possível responder aos sonhos de tantas pessoas, não é possível prover emprego e trabalho para tanta gente, o tempo da abundância está chegando ao fim e isso se evidencia na interpretação do presente como uma progressiva piora das condições e progressivo encerramento das possibilidades: a vida não dá sinais de voltar ao normal que se conhecia, o que significa reconhecer que outro normal, mais difícil, parece estar se cristalizando ${ }^{67}$.

\footnotetext{
${ }^{67}$ Esse corte constante entre passado e presente revela o esforço realizado para a compreensão deste presente e, ao mesmo tempo, constrói a imagem do passado - dos últimos anos de crescimento do emprego industrial, da fartura de emprego - de um modo idealizado, quase retirando-o do fluxo do tempo. Nesse sentido, o antigamente se torna quase um tempo mítico,
} 
Finalmente, o último aspecto relativo à cidade, o preço de morar em um grande centro urbano aparece no relato de José, ao dizer dos compromissos assumidos - "Todo dia é difícil. Tem hora que você fica, não é nervoso, a gente fica um pouco meio...como se pode dizer, meio chateado, "pô, mas eu devia estar trabalhando, estou aqui sem fazer nada, não estou ganhando nada", tem luz para pagar, tem água para pagar, telefone para pagar, será que vai dar para pagar? Fica pensando coisas...Fica pondo pensamento negativo na cabeça, tudo isso vem na hora em que a gente está em casa sem ter o que fazer, né? Esses pensamento. E a gente acaba ficando chateado". A comodidade desejada e conquistada tem um preço e esse preço torna ainda mais urgente a necessidade de voltar a trabalhar ${ }^{68}$.

\section{Construindo a vida juntos: a importância do trabalho feminino}

Algo que se destaca no relato de José se refere à importância que o casamento assume em sua vida, determinando uma mudança em suas estratégias de inserção no mercado de trabalho e abrindo a possibilidade de poupar algum dinheiro - usado para a compra da casa, para a realização de melhorias, para a conquista de uma situação mais confortável: "Cheguei aqui, comecei a trabalhar. Era para ter melhorado bem antes, mas eu não me interessei, né? Vim a melhorar mais a minha situação depois que eu casei. Quando eu casei eu não tinha nem uma casa para morar, ainda pagava aluguel. E consegui a minha casa, minha casinha".

Essa fala, já citada mais acima, não chega a revelar todas as conseqüências que o casamento tem para a melhoria das condições de vida da família. Tais conseqüências ficam mais explícitas quando José conta das desventuras vividas até a compra da casa, projeto que foi complicado pela situação do país e aos sucessivos planos econômicos "miraculosos": "mudou, né (depois de casado)? Aí já procurei, porque aí eu também já não estava trabalhando sozinho; minha esposa também começou a trabalhar e nós dois trabalhando e começamos a juntar um

que informa a crítica que velhos e novos fazem ao momento que vivem. Esse aspecto aparece de forma mais evidente nas falas de José e Fátima, que chegaram a São Paulo (e começaram a trabalhar) no início dos anos 70.

68 Os altos custos da cidade como fonte de preocupação e desespero, em contraposição à simplicidade da vida no meio rural, apareceu no relato de vários entrevistados. 
dinheirinho, aí comprei um terreno, paguei esse terreno durante quase três anos, depois achei que o terreno era muito longe e aí vendi aquele terreno e comprei um mais para perto. Paguei esse terreno seis meses e aí perdi. Acabei perdendo o que eu tinha pago quase três anos, já estava quase terminando de pagar, comprei um bem mais caro, perdi o primeiro que eu tinha vendido e perdi esse outro. O primeiro eu não perdi, vendi, mas o dinheiro que eu dei no outro não, enfim acabei perdendo os dois. (...) porque nessa época, foi aquela época no Plano Cruzado, deu uma hora em que o plano falhou lá, aí quebrou...Eu fui um dos que não dei sorte. Aí perdi esse terreno, aí voltei a zero, à estaca zero de novo. Aí nós dois, eu e ela trabalhando, fomos juntar dinheiro de novo. Um ano mais ou menos depois, nós juntamos um dinheirinho, aí apareceu essa casa aqui e a gente comprou, pagamos o dinheiro da entrada e aí foi quando a gente melhorou um pouco, né? Que quando eu comprei essa casa aqui, era apenas só quatro cômodos só. Essa cozinha, dois quartos o banheiro e a sala só. Aqui, essa lavanderia, corredor, garagem não tinha. Mais a casa dos fundos também não tinha. Aí a gente foi fazendo".

Esse "a gente foi fazendo" é fundamental na história de José, porque como aparecerá mais à frente, quando ele fala do futuro que enxerga para suas filhas, o casamento/parceria e o trabalho de ambos os cônjuges será peça chave para a melhoria da vida. E essa necessidade do trabalho de ambos aparece como a marca da sua condição de pobreza: "na minha situação, agora, para quem ganha bem, aí já é diferente, né? (...) para quem ganha pouco, acho que se não trabalhar os dois, fica difícil".

Muito provavelmente, o reconhecimento de que as dificuldades enfrentadas e a insuficiência do ganho do homem, chefe de família, é que complicam a situação e empurram ambos os cônjuges para o mercado de trabalho se torna tão visível na fala de José porque se trata de uma situação que contraria a ordem das coisas. Quando perguntado sobre os significados do desemprego para sua esposa, José respondeu dizendo que "Eu acho que tem diferença sim, né? Porque para a mulher, se a mulher fica desempregada e o homem está trabalhando eu acho que, normalmente, isso é normal. O homem trabalhar e a mulher ficar em casa, seria o certo. Mas como hoje em dia você sabe que o trabalhador ganha pouco, né?". 
A exemplo do motorista de ônibus, a crítica que se faz às possibilidades encontradas no mercado de trabalho se ancora num imaginário de família e num modo de compreender os papéis feminino e masculino que a vida na cidade - a vida dos pobres na cidade - impede que se atualize. É essa rígida divisão dos papéis masculinos e femininos que acaba tornando possível que, embora as mulheres trabalhem e seus rendimentos tenham uma importância fundamental para a sobrevivência e para as conquistas da família, o trabalho delas também acabe passando despercebido, tornado invisível pois que o lugar que ocupam na estrutura familiar não se desloca a despeito de sua contribuição ${ }^{69}$ (cf. Alvim e Lopes, 1990 e Rodrigues, 1978).

O trabalho da esposa, na fala de José, é um trabalho no diminutivo: " $E$ às vezes ela arrumava algum servicinho mas não dava certo, um emprego também não dava certo, trabalhava um mês, dois e saía. Entrava em um, trabalhava quinze dias e saía, é aquela fase que a gente passa, muita gente passa, que parece que nada dá certo para a gente. (...) e agora de um ano para cá, conseguiu um emprego, conseguiu parar no emprego"; ou então "Ela conseguiu esse emprego, foi sorte nossa porque, se estivesse ela e eu desempregado, a coisa estava bem mais feia, porque com esse dinheirinho que ela ganha, o salarinho...O salário que ela ganha, mais um aluguelzinho de $R \$ 200,00$ que eu recebo de uma casa que tem aqui nos fundos. E aí que a gente vive". Esse modo de enunciar é revelador de duas críticas de José à sua situação: 1) o dinheiro ganho pela esposa é menor do que o que ele seria capaz de ganhar, se pudesse trabalhar e 2) o dinheiro ganho, por ambos, é curto para o tamanho das necessidades; assim, tudo parece pequeno, o trabalho que se consegue, o dinheiro que se ganha, a vida que se leva...

Quanto à primeira das críticas, José relata que, de fato, sua esposa sempre ganhou menos do que ele e que seu salário não é suficiente para a cobertura de

\footnotetext{
69 Numa pesquisa sobre a informalidade, realizada em favela da zona sul de São Paulo, o Prof. Álvaro Comin observou que a recorrência do desemprego dos homens - chefes de família - e a maior facilidade que as mulheres encontram para se inserir em serviços, principalmente domésticos (que, ademais, têm um grau maior de estabilidade em relação aos bicos e trabalhos conseguidos pelos homens), têm modificado radicalmente a estrutura familiar, provocando importantes conseqüências para a manutenção simbólica de uma certa figuração da "família" e pondo em xeque a figura do homem-provedor. Para uma discussão sensível sobre o tema, ver também Caetano, 2004 - especialmente o capítulo 5, sobre as trajetórias femininas.
} 
todas as contas: "porque normalmente quando ela estava em casa e eu estava trabalhando, geralmente dava até para a gente manter mais ou menos as condições de vida, né? (...)eu sempre ganhei mais do que ela, mas só dava mesmo para isso, né? Para comer e pagar as contas. Melhorava, a situação melhorava quando os dois trabalhavam, aí começava a sobrar algum dinheiro e aí a gente começava a pensar em comprar alguma coisa, fazer uma reforma na casa, aumentar mais a casa, comprar alguma outra coisa qualquer. Mas quando fica um sozinho trabalhando, só tem que pensar no essencial, só no alimento e pagar as contas, porque nada mais além do que isso dá para fazer"70.

Quanto à segunda crítica, que dimensiona o trabalho e a vida, novamente se apresenta a questão da pobreza, e a afirmação de José, de que "a vida de pobre é só trabalhar" fala dessa estreiteza, que na cidade ganha outros significados pois que existem muitos sonhos e vontades a serem realizadas. As possibilidades de realização, porém, passam pelo trabalho e pela capacidade individual de ir construindo uma vida melhor.

De toda forma, José reconhece que o trabalho conjunto é fundamental para a ampliação desses limites que a vida de trabalho impõe: "ah, se fosse só eu sozinho eu não tinha conseguido. (...) se fosse ela sozinha também não tinha conseguido porque nós dois trabalhando... Está certo que a gente ficava desempregado, como eu te falei ainda agora, que ela ficou desempregada aproximadamente quase dez anos, sem trabalhar com carteira registrada. Mas ela fez alguns bicos, trabalhou muito tempo em casa de família. (...) teve uma época em que ela trabalhou quase um ano numa casa de família".

Para recuperar um aspecto para o qual eu já havia chamado a atenção, a partir daquela fala sobre a insuficiência dos rendimentos do trabalhador para a manutenção da casa, José acredita que o normal seria que fosse ele que estivesse trabalhando e sustentando a casa. Ele é o provedor, donde deriva que o trabalho de sua esposa só pode ser complementar aos ganhos que ele deveria ser capaz de obter. É por essa razão que o reconhecimento de que ela ganha

\footnotetext{
70 "As mulheres brasileiras ganham, em média, cerca de $65 \%$ do que recebem os homens, quando considerados os rendimentos de todos os ocupados, ou seja, tudo aquilo que recebem assalariados, autônomos, empregados domésticos e outros (...) Essa desigualdade está presente nos rendimentos obtidos pelas mulheres, qualquer que seja a sua forma de inserção no mercado de trabalho, embora, ao longo do tempo, a diferença venha se estreitando lentamente. (...)", (DIEESE, 2001: 119-20).
} 
menos não provoca nele qualquer reação - faz parte da vida, tanto quanto o longo período de desemprego experimentado pela mulher, transitando por trabalhos informais de vez em quando e permanecendo a maior parte do tempo em casa. Como José afirma, ao falar dos diferentes significados do desemprego para homens e para mulheres: “isso é o normal”. É desse ponto de vista que o desemprego de ambos se distingue: enquanto a esposa pode ficar em casa e isso ser "normal" se não houver necessidade premente, o estar em casa de José é que é impensável ${ }^{71}$.

O trabalho realizado pela esposa, hoje, é registrado, como empregada doméstica em Alphaville - "E depois de uns tempos, de um ano para cá, ela conseguiu emprego lá em Alphaville, em casa de família, mas registrado, um emprego decente, né?".

\section{Trabalhador sem profissão, sem função}

Na primeira entrevista que fiz com José, conforme a fala já mencionada anteriormente, o último assunto que ele entabulou, comentando as razões às quais creditava a dificuldade em encontrar um novo trabalho, referia-se ao fato de não ter uma profissão. Mais do que a idade ou escolaridade, fatores que em seu entendimento tornavam a situação, difícil no geral, particularmente difícil para ele, José apresentou a falta de profissão como um problema essencial: "Se eu tivesse uma profissão talvez hoje seria mais fácil. (...) eu sempre trabalhei em fábrica, aprendia e depois o que eu aprendia ficava ali...Nunca pude aprender assim uma profissão definida, que você sai do emprego e você encontra ela em outro lugar. Isso aí eu não consegui".

Nessa curta fala, encontram-se alguns elementos para que seja possível compreender quais os critérios que, para José, dão forma à idéia de profissão: trata-se de algo que se aprende, de uma certa especialização, de algo que

\footnotetext{
${ }^{71}$ Para uma discussão bastante interessante sobre a invisibilidade do direito das mulheres ao trabalho devido à tolerância em relação à sua inatividade ou aos seus rendimentos inferiores aos dos homens (posto que se trataria de "renda complementar"), ver Maruani, 2002, especialmente o capítulo 2, "Travailleurs, travailleuses: qui sont les salarié-e-s pauvres?". Essa discussão também está na raiz das diferentes taxas de desemprego oculto pelo desalento segundo o sexo, com as quais trabalhei no Capítulo 1.
} 
confere ao trabalhador uma outra identidade, mais permanente. A profissão se assemelha a um bem, no sentido de que é algo que se adquire e que é possível carregar consigo no trânsito pelo mercado de trabalho. Como já comentei acima, trata-se de uma idéia que se contrapõe à trajetória construída por José todos os trabalhos que teve (nas cerca de dezoito empresas nas quais trabalhou) não foram suficientes para que ele tivesse uma profissão.

É interessante também que nessa fala, José distingue escolaridade de qualificação. Do mesmo modo que critica a exigência da escolaridade para o desempenho de tarefas que nada têm a ver com ler e escrever, José reconhece a existência de um outro saber, esse sim coerente com a diferenciação e a seleção que se dá no mercado de trabalho. $\mathrm{O}$ aprendizado de uma profissão aparece assim como algo que se valoriza na medida mesmo em que sua falta é vista como o principal entrave para uma inserção mais garantida no mercado de trabalho.

A trajetória de José sempre teve esse caráter instável. No entanto, a facilidade de reinserção encobria tal instabilidade, tanto mais porque José encontrava facilmente um novo posto e o período imediatamente após a perda do emprego estava amparado pela indenização ou pelo seguro-desemprego. Assim, o que orientava sua decisão de permanecer ou não em um emprego era a possibilidade de vir a ganhar melhor fora dele, como ele mesmo diz:

"Naquele tempo eu era solteiro, quer dizer, não tinha...Como era fácil de arrumar emprego, você saía de um e já entrava em outro, meu pensamento naquele tempo mais era salário, não era emprego, eu queria ganhar um pouco mais...(e aí eu) resolvia sair, então, e onde que eu achava que estava pagando um pouco mais, aí eu saía, fazia um acordo, pedia para ser mandado embora; quando eles não queriam mandar eu pedia a conta e entrava numa outra empresa para ganhar um pouco mais, sempre meu objetivo era ganhar um pouco mais. E também...Aí eu fiquei nessa aí".

É a experiência de um desemprego de outro tipo que faz com que ele avalie suas estratégias, pondo no primeiro plano de seu olhar a não-constituição de uma carreira: "Eu acho que não foi bom eu ter feito isso porque eu fiquei andando de firma em firma...Quer dizer, fazendo muita coisa que naquele tempo eu achava que 
era certo mas hoje eu acho que não.(...) Eu acho que não porque eu trabalhei em muita firma boa.(...) Se uma dessas firmas que eu trabalhei, se eu tivesse ficado até hoje eu tinha feito um bom negócio, não é? Teria sido melhor para mim".

Nessa avaliação do passado, José também oferece pistas sobre o modo pelo qual a identidade profissional se constrói entre os trabalhadores cujo ponto de partida é a venda de sua força de trabalho não-especializada e não-qualificada: "Eu sempre trabalhava, entrava como ajudante e saía como ajudante porque eu não ficava muito tempo na empresa. Porque para a gente crescer numa empresa, você tem que ficar muito tempo e outra também: algumas vezes, em algumas empresas que eu trabalhei, eles sempre me pediam para mim estudar; às vezes, o encarregado da seção, o encarregado de seção chegava e falava "você tem que estudar porque senão você não vai crescer" e eu falava que ia estudar, por fim acabava esquecendo, não estudava". A qualificação relacionada ao setor de atividade, tomando parte de uma estratégia de constituição da identidade profissional, aparece assim - nos conselhos ouvidos por José - como a maneira privilegiada de construção de uma trajetória de mobilidade ascendente.

Como estudos recentes têm mostrado (Guimarães, Hirata, Montagner e Watanabe, 2003; Guimarães, 2004), há um deslocamento fundamental no padrão das relações de trabalho que se evidencia na passagem na recorrência do emprego à recorrência do desemprego. Esta abordagem é interessante pois que contribui para melhor cercar esse universo dos trabalhadores que construíam suas trajetórias transitando entre empregos, conforme as possibilidades ou a necessidade que tivessem dos fundos constituídos a partir das relações trabalhistas.

Nesse sentido, nesse universo, se é verdade que o imaginário do emprego se constrói em oposição à instabilidade e à precariedade dos bicos e de tudo aquilo que é trabalho sem ser emprego, tal imaginário nada tem a ver (como poderíamos imaginar) com a idéia de carreira. Se há algum elemento que insira a estabilidade como aspecto ligado ao emprego, tal elemento se refere aos direitos a ele associados - o Fundo de Garantia por Tempo de Serviço, o segurodesemprego, a contribuição ao INSS... -, ou seja, a estabilidade é circunscrita ao 
curto e médio prazo, visando cobrir os custos pessoais e familiares nos períodos de desemprego, que são vistos como parte da trajetória.

Dessa forma, o bico, o trabalho "sem ser fichado", se opera como mantenedor da identidade do trabalhador, atualizando-a, ainda assim diferencia-se do emprego porque introduz a precariedade e a privação no horizonte imediato da cessação da atividade.

Ao contrário da recorrência do emprego, que possibilita a constituição de uma trajetória menos descontínua, a situação de recorrência do desemprego complica a situação dos trabalhadores, pois o capital social e as redes interpessoais acabam também se desfazendo. Nada, nem aprendizado, nem contatos com colegas, acumula-se e o trabalhador fica mesmo abandonado à sua sorte (cf. Guimarães, 2004).

Ao imaginar o que seria diferente se houvesse permanecido na mesma empresa por bastante tempo, ou se houvesse permanecido no mesmo ramo de atividade, José diz que “...teria dado continuidade", o que significa dizer que suas chances de acumular uma experiência e constituir uma identidade profissional seriam maiores.

Numa situação diametralmente oposta à de José, está situada a história de Demerval, cuja trajetória levou à constituição de uma identidade profissional que não se desfaz à despeito do longo período de desemprego ou da assunção de uma atividade informal como forma de "viração". À exemplo da preleção feita pelo motorista do ônibus, introduzo aqui a história de Demerval para fixar alguns aspectos que a trajetória de José permite discutir.

Em setembro de 2002, conheci Demerval: eu estava em um ponto de ônibus quando esse rapaz se aproximou, oferecendo pastilhas Garoto. Após haver comprado e aproveitando que ele também estivesse à espera de um ônibus, perguntei se ele trabalhava com comércio há muito tempo, ao que ele respondeu que não, que fazia "somente" dois anos. Perguntei então qual era a sua profissão e ele respondeu "metalúrgico", ficando um longo tempo em silêncio. Voltei a lhe questionar, perguntando o que havia acontecido e ele contou que todos os trabalhadores da forjaria em que trabalhava haviam sido 
demitidos, devido à transferência da fábrica para o interior. Contou que procurara emprego no setor de origem durante algum tempo, mas então, como os salários eram muito mais baixos do que o do trabalho anterior, ele resolveu "se virar" e começou a vender balas.

Demerval é separado, tem filhos e paga pensão. Quando contei a ele o tema de minha pesquisa, ele foi categórico: não é que as pessoas não encontrem empregos, mas elas acabam preferindo fazer uso de outras estratégias porque não encontram quem pague o preço "justo"; ele disse ainda que só volta para a indústria se encontrar um patrão que pague o preço que seu trabalho vale.

Demerval não era ligado ao sindicato e, durante nossa conversa, demonstrou prezar o compromisso com a empresa; ou seja, sua interpretação não é fruto de qualquer "radicalismo" político. O fato de ter uma profissão, de ter um ofício, é que lhe coloca numa posição muito diferente em relação à José. No caso de Demerval, ainda que tenha havido abandono da atividade de procura, a identificação com a profissão não se desfez: Demerval é filho de metalúrgico, seus irmãos são metalúrgicos e ele começou a conversa dizendo que "metalúrgico é a melhor profissão do mundo". Portanto, é desse lugar que Demerval observa e interpreta o presente, um lugar no qual a identidade está tão claramente estabelecida em torno do "saber fazer" que prescinde mesmo da atualização por meio do exercício de uma atividade concreta ${ }^{72}$.

Se introduzi a história de Demerval nessa seção que trata da diferenciação que a narrativa de José permite fazer entre profissão e função é para retomar alguns pontos da discussão sobre o caráter de labor que estou atribuindo às atividades exercidas por José ao longo de sua vida. Ainda que a "ética do provedor" 73 seja suficiente para dotar o trabalho de sentido e para afirmar uma

\footnotetext{
72 Apenas mais um comentário a respeito de Demerval: depois que me despedi dele (quando o ônibus que eu esperava passou pela $4^{\mathrm{a}}$ vez), ao olhar para trás, vi que ele sorria. Ele havia ficado parado durante quase uma hora, apenas conversando (o que não é pouco se tivermos em conta que ele vive da venda das balas), e interpretei o sorriso de Demerval como uma alegria pelo reconhecimento. Ao perguntar sobre sua profissão de origem, foi como se tivesse confirmado para ele como era visível a sua história de trabalho, como era visível que aquele não era o seu lugar.

${ }^{73}$ Cf. Zaluar, 1990.
} 
identidade de trabalhador ${ }^{74}$, trata-se de um sentido que se esgota no fazer: a manutenção da casa ainda significa manutenção da vida, assim como a manutenção simbólica da própria identidade.

Trata-se, portanto, de sobrevivência - real e simbólica - e isso significa dizer que os frutos do trabalho são consumidos no presente, sem produzirem nada mais durável. E é isso que o sofrimento pelo desemprego prolongado revela, no caso de José, pois toda a sua vida de trabalho não lhe conferiu nem alguma estabilidade financeira, nem uma identidade mais duradoura - uma profissão - e nem instrumentos que pudessem orientá-lo para a compreensão do que está acontecendo. É por essas razões que seu trabalho, ainda que mediado por diversos elementos da cultura do trabalho (tais como honestidade, responsabilidade familiar, diligência e retidão de caráter), não deixa de ser labor.

Muito diferente da trajetória de Demerval, que, ao aprender um ofício, constrói para si uma identidade que persiste a despeito da impossibilidade de conseguir um emprego no mesmo setor de atividade - o sentimento de orgulho, a capacidade de interpretar e de tomar uma posição em relação à deterioração das condições de trabalho, o sentimento de transitoriedade em relação à atividade ora desempenhada, todos estes são elementos que não estão presentes na história de José e esta falta é reveladora de uma diferença fundamental: enquanto Demerval viveu a experiência do trabalho concreto, que produz coisas de caráter mais permanente, José viveu a experiência do trabalho abstrato, quase puro labor, que não produz mais do que consumo.

\section{"Ganharás o pão com o suor de teu rosto": o trabalho como horizonte}

Ao falar das filhas e do futuro que imagina para elas, José também pôs em cena importantes elementos de avaliação de sua situação atual.

A filha mais nova, de 17 anos, mora com ele e a esposa e está no primeiro ano do Ensino Médio. $\mathrm{O}$ atraso escolar se deveu à uma doença que ela teve

\footnotetext{
${ }^{74}$ Como a fala de José explicitará mais adiante, este trabalhador era uma figura até há pouco tempo facilmente reconhecível em contraposição à figura do vadio, do malandro ou do desempregado recorrente devido, geralmente, ao álcool.
} 
quando pequena; só aos dez anos, quando se recuperou, é que pôde entrar na primeira série do ensino fundamental. Em relação à esta filha, José parece considerá-la como bastante tranqüila, sossegada, de pouca conversa, quase ingênua. Quando fiz a entrevista, ela estava em casa mas não se interessou em falar comigo, permanecendo todo o tempo à frente da televisão.

A avaliação que José faz da filha mais nova está, em grande parte, referida à filha mais velha, que hoje tem 21 anos. Essa filha, já casada, "deu muito trabalho", pois queria mais coisas do que o pai podia oferecer, envolveu-se com más companhias e precisou da atenção dos pais para se manter num "bom caminho". A partir do momento em que começou a trabalhar e que se casou, porém, tudo ficou melhor, e ela passou a assumir suas responsabilidades.

Perguntei a José se ele conversa com suas filhas sobre o trabalho e o que imagina para o futuro delas. Sua resposta revela que o estímulo ao trabalho, principalmente em relação à filha mais velha, está ligado às necessidades de consumo: "ela eu estimulei mais porque ela...Ela era assim, né? A Flávia que é a mais velha e é casada, é totalmente diferente dessa que está em casa. Ela começou, com uns catorze anos para cima ela já queria de tudo: ela queria calça de marca, tênis de marca, ela queria que eu fizesse coisas que eu jamais teria condições de fazer por ela. Então, (eu falei), se é assim você vai ter que trabalhar. Então no começo ela deu um pouco de trabalho porque ela não tinha condições de arrumar emprego porque ela era novinha, né? Mas depois, com 16 anos, ela já começou a trabalhar, entrou numa loja, e começou a trabalhar. Trabalhou seis meses e já casou também. Casou com 17 anos".

É bastante interessante observar que o início do trabalho coincide com a assunção da própria vida e, em certo sentido, com a concretização da passagem para a vida adulta pois depois de ter começado a trabalhar, Flávia se envolveu mais com o namorado, abandonou os estudos e se casou.

José, embora feliz com o senso de responsabilidade demonstrado pela filha, ainda assim se preocupa, pois avalia que ela não adotou a estratégia correta e, se não completar os estudos, estará sujeita à mesma situação em que ele hoje se encontra: "eu acho que ela vai ter dificuldade, sim, porque ela estava estudando, quando ela estava solteira, antes de casar e ela estava quase terminando o 
colegial, né?(...) ela estava terminando o colegial, o terceiro ano do colégio, no meio do ano ela parou. Que ela se envolveu muito com o namorado e só queria ficar junto com ele. Aí arrumou o emprego também, e aí começou a se concentrar no emprego e namorar e deixou de estudar, parou de estudar. Parou assim, simplesmente não foi mais, não voltou mais na escola, acabou... não terminou o terceiro colegial e ficou nisso até hoje e não voltou mais a estudar. Apesar de que ela consegue emprego, ela consegue emprego com muita facilidade em vista de mim por causa da aparência, que ela tem uma aparência boa, né? É bonita, tem uma boa aparência, acho que é mais por isso que ela consegue, né? Também, isso aí ajuda muito também. Eu não sei quando ela chegar na minha idade como é que vai ser, ou nem precisa chegar na minha idade, talvez daqui a dez, quinze anos. Eu acho que se ela não voltar a estudar eu acho que ela vai passar pelo mesmo caminho que eu estou passando hoje".

Essa última imagem, "passar pelo mesmo caminho", é reveladora dos critérios que orientam a avaliação que faz das possibilidades abertas à sua filha. Sua preocupação é a de que, a despeito dos esforços para que ela estudasse, a relativa facilidade em encontrar trabalho - que hoje ela encontra devido à aparência - a leve a construir uma trajetória parecida com a do pai, sem acúmulo de conhecimento, sem especialização; sem, portanto, desembocar na constituição de uma profissão.

A preocupação também se apóia na interpretação que faz sobre a realidade vivida por Flávia, projetando os elementos negativos de sua própria vida sobre as possibilidades de futuro ao alcance da filha: "Eu tenho a impressão de que ela vai sempre ter que trabalhar, pelo resto da vida dela, porque eles começaram do nada quando casaram, pagam aluguel e tudo, porque eles trabalham só para pagar o aluguel e comer, vestir, né? Dificilmente eles vão ter condições de comprar...Tenho certeza de que um dia eles vão comprar, mas pelo menos acho que por um bom tempo ainda eles não vão ter condições de comprar uma casa para morar. Então eu acho que ela vai ter que trabalhar por muitos anos, né? Como ela não quis estudar mais, né? Porque eu sempre falava para ela, que ela estudasse, que eu não queria que ela passasse o que eu passei, pelo que estou passando, ela não quis me ouvir". Olhando o presente da filha a partir da perspectiva de quem hoje vive o desemprego, José consegue visualizar claramente a dinâmica da pobreza que caracterizou sua própria vida - com sua 
instabilidade constante que torna os indivíduos vulneráveis à situação mais geral do mercado de trabalho.

A vida sem trabalho é inimaginável: é o trabalho que possibilita a progressiva melhoria e é o trabalho conjunto que possibilita que os ganhos não sejam apenas utilizados para a sobrevivência imediata. Uma vida de trabalho é que constrói alguma coisa. E José apanha com clareza o fato de que a filha, mesmo tendo nascido e sido criada na cidade, compartilha seu ponto de partida com o pai, que veio sem nada - ela e seu marido também estão começando do nada; tudo está por construir.

O que José percebe, agora, é que mesmo as possibilidades de construir um futuro por meio do trabalho estão ameaçadas, nessas novas configurações do mundo do trabalho. Então, ele se preocupa com o futuro da filha, cuidando para que ela não compartilhe de seu destino.

É importante chamar a atenção para esse aspecto de que a vida sem um trabalho é inimaginável. José conta que tentou pensar em maneiras alternativas de ganhar a vida, mas que, ao fim, voltava sempre ao emprego, como a forma mais acessível a ele. Afinal, montar um negócio próprio é caro e depende de inúmeras negociações, alvarás, pagamento de impostos. Além disso, dependendo de como as coisas forem feitas, fica-se à mercê dos fiscais, policiais etc. É então que a solução encontrada é voltar a procurar: "a gente não consegue encontrar uma solução. Trabalhar por conta, como é que eu vou trabalhar por conta? Como que uma pessoa que está desempregada, que não tem dinheiro nem para procurar emprego, vai trabalhar por conta? Vai sair vendendo sorvete por aí, vendendo bala? Não dá nada, você só vai andar à toa e perder tempo. Porque dinheiro para montar alguma coisa a gente não tem. (...) chega uma hora que a solução, você não tem outra saída; você volta àquilo mesmo que você estava antes: é procurar, a solução é procurar".

Referindo-se ainda a esse período em que tentava imaginar uma alternativa, José reitera essa idéia de que o trabalho é a única maneira que se apresenta para ganhar a vida: "a gente fica preocupado porque, a gente fica com medo, dá a impressão que a gente não vai conseguir mais emprego, aí como é que vai ser a vida da gente? As dificuldade que a gente vai ter, que a gente passa. Que a partir 
do momento que você está desempregado, que o seu dinheiro acaba, você começa a ter dificuldade, né? Aí você começa a pensar: "pô, mas e se eu não conseguir emprego, o que é que eu vou fazer? Como que eu vou comprar a comida para dentro de casa, como que eu vou pagar as minhas contas, minha água, minha luz, o telefone"?

"Como" é o centro da questão. O relato de José explicita que se trata de uma aporia: para montar um negócio, é preciso dinheiro; para ganhar dinheiro, é preciso trabalhar ${ }^{75}$. O trabalho é o meio de ganhar e construir a vida, e é também a medida do possível, pois é a partir do que ele é capaz de produzir - no sentido mais extenso - que se definem os limites da vida.

\section{O que é estar desempregado? - o conhecimento de quem experimenta}

Ao comentar a própria situação, José várias vezes dizia "ninguém mais do que eu sabe...". A experiência the tem ensinado muito sobre o que é estar desempregado hoje, o que significa sair para procurar e não encontrar, perceber as mudanças nas formas de procurar e se sentir "desorientado"...

José contou que, geralmente, não avisa as pessoas quando perde o emprego, só depois de algum tempo ou depois que encontra um novo trabalho. Segundo ele, amigos, vizinhos e parentes nem sempre reagem bem, provocando mais desassossego ao invés de oferecerem apoio. Para se preservar de comentários desagradáveis, então, José prefere manter segredo.

Mesmo em relação à esposa, José disse que ela não entende a situação pela qual ele está passando, principalmente porque está trabalhando. Perguntei, então, se ele acha que as pessoas, quando estão trabalhando, têm dificuldade para compreender e ele respondeu: "Eu acho que têm porque eu mesmo não entendia. Eu estava trabalhando; por exemplo, quando eu estava trabalhando, o meu

\footnotetext{
75 Vale a pena comentar um dos principais desafios enfrentados pelas instituições incubadoras para construir a viabilidade dos empreendimentos formados a partir do Programa Oportunidade Solidária, da Secretaria de Desenvolvimento, Trabalho e Solidariedade, Prefeitura Municipal de São Paulo. Os grupos não queriam, de jeito nenhum, tomar empréstimos - e as explicações para isto foram as mais variadas, desde a falta de uma cultura empreendedora até a falta de confiança mútua entre os grupos. Mas, ouvindo José, parece claro que essa postura está orientada por uma visão de mundo que tem no trabalho sua principal medida: não é possível tomar de empréstimo mais do que se pode trabalhar. O "horizonte da vida", por assim dizer, é aquele que o próprio trabalho permite construir.
} 
genro ficou desempregado aproximadamente um ano, ou um pouco mais. E ele era um rapaz novo, um rapaz de vinte e cinco anos, e eu achava que ele não arrumava emprego porque ele não queria, que ele não estava querendo trabalhar. Meu pensamento era esse. Então agora que eu fiquei desempregado é que eu estou vendo a situação que ele passou, que não era bem aquilo que eu pensava".

Por sua vez, o genro, tendo recentemente vivido a experiência de um longo período de desemprego, é capaz de compreender melhor a situação: "Ele (o genro) entende sim. Mas só que quando eu estava trabalhando e ele estava desempregado eu achava - nunca cheguei a falar isso para ele, porque eu não ia falar mas eu achava "pô, ele não arruma emprego porque não quer trabalhar"; um rapaz novo, com estudo, com tudo e não consegue arrumar emprego? Enquanto eu, o maior tempo que eu fiquei desempregado foi seis meses, nove meses, seis meses e já conseguia um emprego e ele não consegue, tem muito mais chance de arrumar um emprego do que eu? Só que eu estava trabalhando, né? E geralmente as pessoas que trabalham nunca vai entender a situação de uma pessoa desempregada. Eu acredito que tenha algum desempregado que está acomodado, que não liga mais de arrumar emprego mas a maioria se esforça para arrumar, eu acho que sim".

Há vários aspectos importantes nessa fala. A primeira delas se refere aos critérios de empregabilidade, (idade, escolaridade, experiência), que não parecem ter correspondência na realidade. O mais incompreensível para José era que alguém, com muito mais empregabilidade que ele, não conseguisse trabalhar.

O segundo aspecto se refere à valoração do comportamento do desempregado, com importantes deslocamentos em relação ao passado recente: o esforço para encontrar um novo posto de trabalho, ainda que legítimo, não resulta necessariamente em encontrá-lo.

Opera-se uma mudança fundamental, que distingue os desempregados de ontem e os desempregados de hoje: "Antigamente era: ou porque estava escolhendo ou porque não queria trabalhar porque antigamente tinha serviço à vontade para quem quisesse trabalhar. Eu tiro isso por mim, porque eu ficava desempregado uma semana, um mês, no máximo, e achava outro emprego.(...) Algumas pessoas que eu me lembro que ficavam muito tempo desempregado naquela época eram pessoas que tinham 
problema, né? Saía, às vezes ficava desempregado porque já tinha...Às vezes se envolvia com outras coisas, com qualquer coisa, aí já... caso já não era mais esse. Pessoas que se envolviam com outras coisas e não queriam mais trabalhar, mas não por falta de emprego"76.

A falta de emprego é o problema que transforma os desempregados de hoje em pessoas que, a despeito de não encontrarem trabalho, merecem que se atribua a eles valor, como se estivessem trabalhando. A situação de desemprego, nesse sentido, deixa de ser sinal de um problema individual e pode ser compreendido como um destino comum a um grande número de trabalhadores. O que a fala de José também revela é que não é o volume de desemprego que importa para operar esse deslocamento - pois aqueles que estão trabalhando não experimentam as mudanças, julgando a partir das mesmas referências anteriores -, mas a experiência de se sentir "merecedor" e não receber nada em troca. Talvez aí o discurso das oportunidades encontre fértil terreno para se enraizar como explicação - faltam empregos, faltam oportunidades; quanto a mim, faço o que posso.

José não avalia que as coisas estejam melhorando ou em vias de melhorar: "Hoje sim (há falta de emprego). Hoje, as coisas, me dá a impressão que a cada dia que passa as coisas vão ficando pior. Ao contrário do que a gente pensa; pensa que vai melhorar e não melhora. Cada dia que passa as coisas, sobre esse lado de emprego, parece que vai se complicando mais". É essa avaliação que orienta a sua escolha por parar de procurar ou procurar realizando o mínimo de esforço possível.

\section{As novas formas de procurar: a construção do desalento}

Ao longo de seu tempo de desemprego, José alternou períodos de procura com períodos em casa. Nos primeiros seis meses após a demissão, ficou em casa, sem procurar, realizando reformas e usufruindo do seguro-desemprego. Em seguida, começou a procurar. Procurou por alguns meses e parou um pouco, cansado pela frustração da procura: "A palavra certa não é que eu desanimei, na hora foi a única coisa que me passou pela cabeça e eu te falei, mas não foi

\footnotetext{
${ }^{76} \mathrm{O}$ universo dessas "outras coisas" é constituído principalmente pela bebida.
} 
isso, eu não desanimei. Eu jamais vou desanimar. Então, eu dei uma parada, achei que estava muito difícil, não é? Então, como graças a Deus eu tenho minha esposa que trabalha e o que ela ganha dá para a gente viver, então eu dei uma paradinha, não é? Esfriar a cabeça, eu estava um pouco de cabeça quente também, estava meio desesperado, então falei, vou dar uma parada, uma paradinha para ver depois o que é que eu vou fazer. Depois eu fiquei uns tempos parado em casa e agora voltei a procurar de novo".

Essa intermitência da procura desagrada sua esposa, que gostaria que ele demonstrasse mais esforço para encontrar um novo trabalho: "Ah, tem hora que ela...ela fica nervosa também. Porque se fosse por ela, eu saía todo dia procurar emprego. Às vezes ela acha, ela fala que eu estou meio devagar, que eu estou desanimado, não estou querendo mais procurar emprego. E eu falo, "não, não é isso", é que a gente fica assim (porque) você vai num canto, você vai no outro, você nunca consegue nada. E outra que eu não tenho dinheiro para ficar saindo todo dia procurar emprego. Ela acha que eu tinha que se esforçar mais. Talvez ela tenha razão, mas...Eu acho que eu estou fazendo o que eu posso fazer, entendeu?(...) porque eu vejo, ela fala assim porque ela não sabe qual é a situação que está aí fora, ela está trabalhando, né? Eu acho, eu que estou passando pelo problema, eu é que sei; ninguém mais do que eu sabe a situação...o quanto é difícil a gente sair para procurar emprego. Às vezes sair sem nem saber onde você vai.(...) Outra coisa é que você não pode sair, a torto e a direito, gastando dinheiro sendo que você não tem dinheiro para gastar. Porque um...Para quem está desempregado, um real que a gente gasta, dois, três, quatro, cinco reais faz diferença".

José fala, portanto, do desânimo de procurar em vão, sem conseguir nada. É importante notar que esta não é a primeira vez que José permanece desempregado por um longo período - ele já chegou a ficar nove meses desempregado. Mas desta vez, ele percebe que se trata de uma nova situação, pois não vê perspectivas de retorno imediato; percebe que a situação está difícil e, por isso, decide que vale mais a pena suspender a procura por algum tempo. Nessa fala há uma pista para a compreensão de pelo menos um dos aspectos da mudança: José não sabe aonde ir. Geralmente, restringe sua procura ao Centro de Solidariedade, pois se trata de um lugar centralizado, no qual o esforço que se realiza é menor. 
José disse que raramente procura emprego em agências e mostra que sua desorientação na hora de procurar um novo trabalho se deve a uma mudança importante dos modos de procurá-lo: “Que você sabe que mudou de uns anos para cá, entrou esse negócio de firma terceirizada, agência, tudo isso e acho que isso que complicou mais o país, quer dizer, o trabalhador, né? Porque antigamente, até mais ou menos 85, 86, a gente procurava emprego diretamente nas empresas, eu saía daqui da minha casa, por exemplo: estava precisando de alguém lá na Estrela por exemplo, ou outra empresa qualquer, eu tinha informação que estava pegando alguém lá, eu ia direto para lá, eu ia direto na empresa. Eu não ia procurar serviço em agência nenhuma, nem em centro de solidariedade - porque não existia também, naquela época. Começou com as agências. Para começar eu nunca procurei serviço em agência. Sempre que eu procurava era diretamente nas firmas, não é? Agora como hoje já não existe mais isso, praticamente, dificilmente você vai procurar emprego numa fábrica, numa empresa porque não existe mais, então, eu deixei de procurar".

Quanto às agências, José explica porque não gosta de recorrer a elas: “Eu não gosto, eu não gosto porque você chega lá - principalmente eu que tenho dificuldade para escrever - aí você faz, chega lá, tem um trabalho danado, faz uma fichinha, faz tudo e aí você fica aguardando, não te chama nada, então todo o esforço que você faz é em vão. É por isso mais que eu não vou, por isso aí". Sair para procurar em vão, realizar esforços em vão - essa é a angústia de José. Antigamente, ele conhecia o funcionamento das coisas e sabia onde, quando, como procurar um novo posto de trabalho. Hoje, ele também conhece os passos necessários, mas reconhece que se trata de uma forma que lhe desfavorece.

Quando se procurava trabalho em fábrica, os critérios para a contratação tinham mais a ver com a empatia e a capacidade de desempenhar o trabalho, em suma, a relação estava menos mediada pelos critérios que hoje constroem a empregabilidade. Durante o trabalho de campo, ouvi inúmeras histórias de homens e mulheres que foram desconsiderados por estar fora dos padrões exigidos pelas empresas, por arbitrários que sejam ${ }^{77}$. Essa barreira,

\footnotetext{
77 A centralização das atividades de seleção nas agências não impede, no entanto, que os critérios de empregabilidade construídos circulem e operem mesmo por meio de pessoas que estão fora das agências. Uma das entrevistadas, Maria, de 44 anos, relatou a seguinte situação:
} 
intransponível, é que é a novidade e a desistência de José está em grande medida informada pelo reconhecimento de sua existência.

A trajetória de José, e sua maneira de narrá-la, sugere que seu desalento é uma novidade, provocada justamente pela dificuldade de compreender e encontrar um novo lugar na situação atual. Ele reconhece a falta de oportunidades e reconhece, também, as faltas que complicam sua situação (de profissão, de escolaridade, de juventude). Mas, novamente, essa compreensão o leva a uma aporia: para modificar seus atributos pessoais, seria necessário voltar à escola, estudar, fazer cursos e, para que isso fosse possível, seria necessário voltar a trabalhar ${ }^{78}$.

Quanto às faltas externas a ele, José as leva em conta para decidir se volta ou não a procurar. Mas mostra que é difícil obter indicadores confiáveis sobre as mudanças - os indicadores apresentados nos jornais não parecem corresponder à realidade que ele enfrenta: "Eu assistia televisão às vezes eu via alguma coisinha, passava no jornal que estava melhorando, melhorando o nível de desemprego, daí voltei a procurar de novo. Não adiantou nada, continua a mesma coisa, não mudou nada. Desde que eu fiquei desempregado que nada mudou, a mesma coisa, talvez pior".

As dificuldades para encontrar um novo trabalho parecem se perpetuar, e a sensação de que nada mudou e nada está mudando - no que se refere às barreiras encontradas para retornar ao trabalho e às dificuldades enfrentadas acaba por imobilizar José, que não tem estímulos para continuar procurando mesmo que não enxergue outra saída para sua vida que não seja voltar a trabalhar.

Em seu caso, o desalento dá notícia dessa imobilidade - que se contrapõe radicalmente ao seu ininterrupto trânsito pelo mercado de trabalho. O

uma empresa abriu vagas e chamou à seleção em suas próprias dependências. Maria se dirigiu até lá e foi barrada pelo segurança, que a impediu de entrar porque ela tinha cabelos brancos, não preenchendo os requisitos necessários à vaga. Além de oferecer exemplo de um óbvio e gratuito exercício de autoritarismo, a atitude do segurança mostra como alguns discursos circulam e operam na prática cotidiana das pessoas.

${ }^{78}$ Quanto à volta à escola, José relatou ter tentado voltar a estudar, mas não suportou o modelo das aulas, que o obrigavam a ficar sentado por um longo período. 
encerramento em casa, ainda que decidido a partir da observação da situação atual, não deixa de causar sofrimento, e é então que o esforço de manter o equilíbrio, de manter a cabeça forte aparece. Equilíbrio constantemente ameaçado pela experiência de que, desde que ficou desempregado, nada parece ter mudado (o que, nesse caso, indica que tudo mudou): "Então, logo nos primeiros dias em que eu resolvi dar uma parada, fiquei em casa, nos primeiros dias eu fiquei um pouco meio agitado, tinha hora em que eu ficava um pouco meio desesperado, mas depois eu procurei me acalmar, eu procurei me controlar...E estava até acostumando a ficar em casa...Mas não é bom, não. Chega uma hora em que você...Acho que ficar dentro de casa mesmo é só para quem está doente, porque a gente tendo saúde não dá para ficar. E aí resolvi dar uma procurada mas... Vi que está a mesma coisa, não mudou nada". 


\section{CAPÍtUluO 4 - MULHER É DESDOBRÁVEL?}

"Vai ser coxo da vida é maldição para homem. Mulher é desdobrável. Eu sou"

(Adélia Prado)

Antes de passar à exposição das trajetórias de trabalho de Fátima e Suely, cabe um breve comentário sobre as trajetórias de trabalho "tipicamente femininas", para que seja possível balizar os achados de campo e apreender melhor a riqueza de questões que as trajetórias de ambas, tão atípicas e heterogêneas entre si, propõem ao nosso pensamento.

Diversos autores têm chamado a atenção para aquelas que parecem ser as características do trabalho feminino no mercado de trabalho brasileiro (entre outros, Hirata e Humphrey, 1989a; Alvim e Lopes, 1990; Hirata, 2002; Rodrigues, 1978, DIEESE, 2001 e Aquilini e Costa, 2003): o primeiro aspecto que chama a atenção é que, ainda que tenha ocorrido uma intensa entrada feminina no mercado de trabalho, as desigualdades de acesso ao emprego e também as desigualdades de acesso a determinados tipos e posições ocupacionais e a certos níveis de remuneração permanecem existindo. Trata-se de uma dinâmica que é reveladora do descompasso de temporalidades entre as mudanças ocorridas nos termos da divisão sexual do trabalho e aquelas que têm lugar nas relações sociais de sexo/gênero, conforme a interpretação de Helena Hirata (2003e).

Na região metropolitana de São Paulo, em 1999, as mulheres compunham 52\% da População Economicamente Ativa (DIEESE, 2001). Apesar de serem maioria no mercado de trabalho, a taxa de desemprego feminina é sempre superior à masculina - enquanto a taxa de desemprego masculina, em 2002, foi de 16,5\%, a taxa de desemprego entre as mulheres chegou a 22,3\% (Aquilini e Costa, 2003, trabalhando com dados da PED). Sem falar na diferença que a variável gênero revela na composição da taxa de desemprego oculto pelo desalento, como vimos no Capítulo 1: em 2001, 65,7\% das pessoas que se encontravam nessa situação são mulheres, o que revela que o desemprego feminino tem mais chances de ficar "invisível”, ou seja, de não ser reconhecido como privação ao trabalho, devido às representações sociais que 
persistem sobre o homem como o provedor da casa e da remuneração do trabalho feminino como sendo uma forma de complementação ou apoio ao sustento da casa. São essas representações que colocam o desemprego feminino da fronteira com a inatividade ${ }^{79}$.

Para a caracterização do que seriam trajetórias "tipicamente femininas", o que importa sublinhar, além dessas importantes desigualdades de gênero, refere-se ao tipo de ocupação mais comumente encontrada pelas mulheres ${ }^{80}$ : a forma predominante de inserção é no setor privado (44,8\% das mulheres ocupadas em 1999), a exemplo do que ocorre para o conjunto dos trabalhadores. No entanto, conforme os dados da PED, (1999), 11\% dessas mulheres ocupadas no setor não possuíam registro em carteira, estando privadas dos direitos e benefícios associados a ele. O emprego doméstico é o segundo em importância, ocupando 19,6\% das mulheres - "Esse número significativo mostra tanto a permanência de papéis tradicionais para as mulheres no mercado de trabalho, associados ao cuidado doméstico, como se soma aos indicadores da precariedade da inserção, uma vez que o emprego doméstico apresenta os menores níveis de vínculo formal de trabalho e, na grande parte dos casos, jornadas de trabalho irregulares e más condições de trabalho", (DIEESE, 2001, pp.113-4). Em seguida, aparecem as mulheres que trabalham como autônomas (16,5\%); em São Paulo, embora o conjunto de mulheres autônomas para público seja maior, o trabalho autônomo para empresas mostra alguma importância ${ }^{81}$.

\footnotetext{
${ }^{79} \mathrm{O}$ reconhecimento de que o desemprego oculto pelo trabalho precário é composto principalmente por homens (em 2001, 62,3\% dos desempregados nesta situação eram do sexo masculino) reforça essa interpretação, pois revela que as razões da "invisibilidade" do desemprego masculino se deve, principalmente, às pressões para a manutenção do sustento da casa. Sobre o "halo do desemprego", ver Maruani, 2002. Sobre os diferentes significados do desemprego e as diferentes pressões que operam no retorno ao mercado de trabalho, segundo o sexo, ver Hirata, 2002c.

80 Estou utilizando aqui os dados da PED de 1999, para a Região Metropolitana de São Paulo, conforme apresentados em DIEESE, 2001, "As mulheres no mercado de trabalho", pp.103-126).

81 "O autônomo para o público é identificado como a pessoa que explora seu próprio negócio ou ofício, sozinho ou com sócio (s), ou ainda com a ajuda de trabalhador (es) familiar (es) e, eventualmente, tem algum ajudante remunerado em periodos de maior volume de trabalho. o indivíduo classificado nessa categoria presta seus serviços diretamente ao consumidor, sem ser o intermediário de uma empresa ou pessoa, tendo liberdade (autonomia) para organizar seu próprio trabalho e, portanto, para determinar sua própria jornada de trabalho, assim como para ter ou não ajudantes e/ou sócios". Por sua vez, "o autônomo para empresa é o indivíduo que trabalha por conta-própria, sempre para determinada (s) empresa (s) ou pessoa (s), mas não tem uma jornada de trabalho prefixada contratualmente e nem trabalha sob o controle direto da empresa, tendo, portanto, liberdade para organizar seu próprio trabalho (horário, forma de trabalhar, ter ou não ajudantes). Essa categoria inclui também o trabalhador vinculado a uma empresa que recebe exclusivamente por produção, cujo vinculo
} 
Os rendimentos do trabalho feminino também são menores em relação aos dos homens - em São Paulo, no ano de 1999, o salário médio das mulheres correspondia a $64,7 \%$ do salário médio dos homens. Mesmo se procura-se ponderar tais resultados incluindo na análise variáveis como escolaridade, raça ou extensão da jornada, a conclusão é sempre a mesma: persistem ainda desigualdades de acesso ao emprego e barreiras à constituição de uma carreira que conduza às mesmas posições ocupadas pelos homens. Em geral, as mulheres têm que se esforçar mais - permanecendo mais tempo na escola e trabalhando mais horas - para conseguir ocupar as mesmas posições ou ganhar os mesmos salários (e esses dois aspectos não necessariamente caminham juntos).

O que se trata de sublinhar, então? Ainda que haja diversidade dentro desse universo cercado pelos dados apresentados acima, o mercado de trabalho que se afigura como acessível para a grande maioria das mulheres é um mercado composto por postos de trabalho cujas funções se aproximam bastante daqueles desempenhadas do ambiente doméstico. Seja como empregadas domésticas, seja como copeiras, secretárias, professoras ou babás, tratam-se de atividades que parecem naturalmente femininas, que não exigem muita especialização ou qualificação, tornando as mulheres facilmente substituíveis. Por trás dessa realidade, persiste a representação da mulher como dependente do homem-provedor, e do trabalho feminino como menos produtivo devido às preocupações com a casa que as mulheres não conseguem deixar de $\mathrm{lado}^{82}$. O risco da gravidez e do conseqüente afastamento por 120 dias também pesa na conta das empresas, já que a estabilidade após a gestação é um direito da trabalhadora ${ }^{83}$.

empregatício é expressamente formalizado em contrato de autônomo", conforme definições da PED (SEADE, 2002, p.14).

82 Como Helena Hirata mostra, na medida em que as funções desempenhadas por homens não são intercambiáveis pelas funções desempenhadas pelas mulheres, esse argumento da maternidade (ou sua possibilidade) perde um pouco de sua eficácia para explicar as decisões das empresas segundo uma seletividade de gênero, (Hirata, 2002). Porém, como a trajetória de Suely vai mostrar, o argumento funciona pelo menos como fator de percepção das próprias condições de empregabilidade. ${ }^{83} \mathrm{Na}$ última década, alterou-se o quadro de que as mulheres, com a chegada dos filhos, afastavam-se do mercado de trabalho (o que dava a seu trabalho um caráter de transitoriedade). As mulheres, atualmente, permanecem mais anos na atividade, sem que isso signifique interrupção da carreira reprodutiva: após o nascimento dos filhos, elas voltam ao mercado de trabalho (cf. DIEESE, 2001). Essa mudança pode ser observada, ainda, nos temas que ocupam as negociações coletivas que 
São esses os aspectos das trajetórias "tipicamente femininas" que gostaria de sublinhar, para que seja possível compreender as especificidades das trajetórias aqui descritas de modo a compreender também a riqueza do material que constituem para a reflexão: no que têm de "desvios" em relação aos padrões, as trajetórias têm também de reveladoras sobre a "norma". Passemos, assim, às histórias de trabalho.

\section{I - Vivendo a perda do emprego formal - Maria de Fátima}

Fátima, embora não aparente, tem 53 anos; é casada e não tem filhos. Branca, cabelos pretos até o ombro e não muito alta, sua voz firme surpreende, tanto mais porque sua maneira de contar histórias e narrar sua trajetória é lúcida e, por vezes, dolorida. A partir dessa observação, não se deve de maneira alguma entender que o tom do relato de Fátima seja "emocional" ou que esteja permeado por reclamações e lamentos. Nada disso. O que impressiona no relato de Fátima é a clareza da narração. Falar de seu trabalho, falar dos marcos referenciais que lhe dão sentido é algo que ela faz sem muito esforço e com prazer, o que me sugeriu que, para ela, a identidade profissional é tão central que ela já pensou inúmeras vezes sobre seu percurso, decorando suas curvas, pedras, buracos e paisagens. A despeito disso, seu relato não aparece como um discurso fechado sobre si mesmo, mas como o esforço de fazer o outro compreender suas experiências, ao mesmo tempo em que lhe dá a chance de novamente se debruçar sobre elas.

Da primeira vez que nos encontramos, ela estava fazendo o caminho de volta da situação de inatividade - perdera o emprego em 1996, ficara de 2000 ao final de 2002 estudando (terminando o segundo grau) e, em janeiro de 2003, resolvera voltar a procurar. Voltamos a nos falar apenas em dezembro de 2003 - no momento em que eu selecionava as histórias que seriam objeto de análise mais aprofundada.

Ao pensar nas pessoas que gostaria de entrevistar novamente, sempre pensava em Fátima. Ainda que, na ocasião da entrevista, sua situação não preenchesse os critérios da pesquisa, a força de sua narrativa me fazia lembrar dela e foi por essa 
razão que a procurei, combinando um novo encontro - que também aconteceu no Centro de Solidariedade.

Para minha surpresa, Fátima não havia encontrado um novo trabalho e não havia procurado emprego desde nosso primeiro encontro. Ainda desejava encontrar um trabalho, na área de metalurgia ou em uma gráfica, mas desistira de sair para procurar, afirmando que só conseguiria um emprego se fosse "pela misericórdia de Deus". Estava se dedicando ao trabalho voluntário - desde aulas de pintura e crochê para crianças, na Igreja, até cursos de pintura para crianças e adultos, no projeto "Escola da Família”, aos fins de semana.

Esses trabalhos voluntários, ainda que ocupassem seu tempo, não substituíam o emprego - "eu sinto muita falta de trabalhar. (...) mesmo assim, fazendo os meus trabalhos voluntários, como as aulas de pintura que eu dou sábados, a catequese também - que eu trabalho na igreja - e dou aos sábados, hoje (terça-feira) eu dou aula de pintura às $14 h$, eu entro às $14 h$, mesmo com todos os meus trabalhos voluntários eu sinto falta de um emprego, muita mesmo, eu acho que o emprego é muito importante na vida da pessoa. A pessoa que não tem emprego, não tem expectativa de vida".

A trajetória de Fátima não é uma trajetória "tipicamente feminina" - ela sempre trabalhou no setor industrial (ainda que realizando as funções reservadas às mulheres, por exemplo, o controle de qualidade) e não teve filhos. Apesar disso, ou por isso mesmo, sua narrativa permite a discussão de aspectos da situação do desemprego oculto pelo desalento que tornam mais complexa - e mais interessante - a tarefa de compreender as mudanças e os deslocamentos que tiveram lugar no mercado de trabalho.

A partir de suas falas, é possível pensar sobre os significados do trabalho industrial na vida de operárias, que começaram a trabalhar na década de 70; é possível pensar sobre os conflitos existentes entre essa geração de trabalhadores e as novas gerações - conflito que aparece colado aos discursos que procuram explicar a violência, localizando suas causas tanto na sociedade (e na falta de empregos e oportunidades) quanto no comportamento dos jovens, reticentes quanto à assunção de responsabilidades e "sem a coragem" necessária para o trabalho; também é possível refletir sobre o caráter dos discursos conservadores, que revelam muito da 
sociedade que se pretende preservar e nos ajudam a identificar quais são os valores que estão postos em xeque pelas mudanças ${ }^{84}$.

Especificamente em relação ao desemprego oculto pelo desalento, a trajetória de Fátima nos permite pensar como se trata de uma situação que, embora incontrolável, não é necessariamente involuntária, passando por uma lúcida avaliação do mercado de trabalho e das próprias possibilidades de reinserção.

\section{Trajetória de Trabalho}

A família de Fátima é do interior de Minas Gerais. Seus tios foram os primeiros a vir para São Paulo. Posteriormente, em meados dos anos 70, sua irmã se casou e também veio, junto com o marido. Em seguida veio o irmão e ela foi a última a chegar. Seu relato revela a compreensão da migração como parte de uma dinâmica que não é apenas familiar, mas se insere num movimento mais geral da população em direção aos grandes centros urbanos - "vim com minha família; igual nortista:quando um vem, traz os outros. Veio a minha irmã e trouxe os restantes"85.

O deslocamento da família em direção à cidade e, mais especificamente, em direção a São Paulo, é informado pelo imaginário de uma vida melhor, mais confortável e se trata de uma melhoria que se realiza por meio do trabalho. Fátima, comentando sua trajetória e comparando passado e presente, mostra que não se tratava apenas de um "sonho", mas de uma possibilidade real, que deixou de existir, na medida em que as oportunidades parecem ter se esgotado: "Você veja bem que vinha alguém da família e os outros vinham atrás à procura de uma vida melhor, de um

\footnotetext{
84 Conservadorismo assume aqui o caráter de uma postura crítica às mudanças sociais em curso, buscando identificar os pontos de desarticulação. A principal preocupação do pensamento conservador - na visão de Nisbet - é a ordem e a integração e é nesse sentido que ele se opõe ao pensamento progressista que ocupou a cena a partir do XIX, cuja fé na razão tinha na mudança, na educação e no indivíduo seu centro (ver Nisbet, 1981).

${ }^{85}$ Em outra ocasião, durante a entrevista, Fátima se referiu a essa migração oriunda do Nordeste, dizendo da impossibilidade atual de pessoas se mudarem para São Paulo, buscando uma vida melhor, sejam elas do Nordeste ou até mesmo do interior do estado. Creio não ser o caso, para os objetivos desse trabalho, discutir se há nisso uma posição que denota preconceito. Como é possível perceber, preferi ler essa fala na chave do reconhecimento da dinâmica de atração que a cidade exercia, bem como dos mecanismos de povoação. A alusão à estratégia das famílias originárias do Nordeste pode ser entendida, assim, no que contém de imagem do movimento migratório: como fuga das más condições de vida, na esperança de uma vida melhor.
} 
emprego, de uma situação financeira mais estável. Hoje em dia é difícil, uma família vem do interior e vai arrumar emprego aonde?".

Ela considera que, no momento de sua chegada à Osasco, era muito mais fácil conseguir trabalho. Conta que em 1974, logo que chegou, já conseguiu trabalho, numa fábrica que produzia rádios - "(naquela época) era super mais fácil. Eu me recordo, na época em que cheguei em São Paulo, em 74, rapidinho (consegui trabalho)...Eu cheguei praticamente sem estudo (...) Aqui era ótimo para você conseguir emprego, você escolhia o emprego. Para você ter uma idéia, a Motoradio colocava faixas "Convide as suas amigas para trabalhar conosco". (...) Verdade. Aí você levava uma colega lá, só falava com o chefe: "Eu tenho uma colega desempregada", aí rapidinho já, nem o teste fazia e já começava a trabalhar. De menor naquela época também trabalhava ganhando metade do salário dos adultos, era muito bom naquela época".

Vale a pena notar os elementos que ela identifica para atribuir um caráter positivo ao mercado de trabalho da São Paulo de meados dos anos 70: 1) permeabilidade do mercado de trabalho: como muitos dos entrevistados apontaram (e é interessante notar que essa fala também aparece entre os jovens que hoje estão no início da carreira profissional) "antigamente" era mais fácil conseguir um trabalho, um emprego. Nem exigências de escolaridade, cursos, línguas; tudo de que se necessitava era vontade de trabalhar. Hoje, em contraposição, todos falam da intensa "competição" do mercado de trabalho; 2) justiça: também bastante recorrente é a idéia de que, "antigamente", os salários eram mais justos e, ainda que se passasse um "apertozinho" mesmo em tempos de trabalho, conseguia-se sobreviver. A justiça também aparece na valorização do trabalho do jovem, que podia ingressar nas indústrias como aprendiz, ganhando a metade do salário do adulto. Em contraposição à resistência que o trabalho dos jovens hoje desperta, principalmente entre homens mais velhos ${ }^{86}$, a possibilidade do jovem trabalhar, desde os 14 anos, assumindo responsabilidades, era percebida como algo bom, que ensinava o valor do trabalho. É claro que, nesse momento, a valorização da experiência abria essa possibilidade: o trabalho do jovem tinha um lugar e um objetivo (a aprendizagem) e não entrava em competição com o trabalho dos adultos; a existência de um "plano de

\footnotetext{
${ }^{86}$ Trata-se de um dado que pôde ser apreendido do conjunto de entrevistas realizadas.
} 
carreira" ou a perspectiva de permanência na mesma empresa dotava esse trabalho de um sentido bastante diverso em relação ao que percebemos hoje e 3) finalmente, novamente em contraposição ao discurso das "portas fechadas" que circula hoje e intimamente relacionado ao aspecto da permeabilidade do mercado de trabalho, a idéia de que existiam mais oportunidades, bastando haver interesse pessoal, reforça o caráter da mudança: hoje em dia, a vontade não é mais suficiente. Essa mudança tem importantes efeitos sobre a percepção social do desempregado, bem como sobre os significados do desemprego. Voltarei a isso mais adiante.

Foi nesse primeiro trabalho que Fátima conheceu seu marido. Casaram-se em 1979. Cabe aqui, pelo que revela das relações de trabalho conhecidas por Fátima, um breve parágrafo sobre a trajetória deste homem. Metalúrgico, ele teve a oportunidade de fazer vários cursos no SENAI, e progressivamente foi melhorando sua situação "ajustador mecânico, torneiro mecânico, fresador, fresador ferramenteiro, fez os quatro cursos". Devido à melhoria da qualificação, conseguia transitar para empregos melhores: "Eu conheci meu esposo lá (na Motoradio). Trabalhamos juntos e aí depois casamos no ano de 79; , aí ele trabalhou acho que um ano ou dois e ele pediu a conta, arrumou um outro emprego em outra empresa. Porque aí ele tinha feito o curso de fresador, não é? Lá no Senai". Em 1999, ele foi demitido. Profissional metalúrgico num momento em que varias profissões da área se extinguiram, novo para se aposentar, "velho" para o mercado de trabalho, a saída encontrada foi abrir um bar na frente de casa - "hoje ele tem um bar, se envolve o tempo todo, então... Também o bar não dá muito lucro, mas pelo menos ele tem uma ocupação". De vez em quando, envia alguns currículos, procurando voltar ao mercado de trabalho - "de vez em quando ele procura, inclusive esses dias eu bati um monte de currículo para ele e ele ficou mandando os currículos. Se aparecer, ele fecha porta do bar vai trabalhar fora"87.

\footnotetext{
87 Note-se, apenas de passagem, a diferença de opções disponíveis - segundo o gênero e o papel familiar - após o prolongamento da situação de desemprego: enquanto Fátima transita para a inatividade, voltando à escola e posteriormente realizando trabalhos voluntários, seu marido continua sendo o responsável pelas despesas da casa, assumindo uma atividade que, embora precária, produz alguma renda. A divisão dos papéis familiares segundo o gênero foi trabalhada a partir da narrativa de José, para quem a normalidade das coisas implica em que seja o homem a prover as necessidade familiares, enquanto a mulher ou permanece no espaço da casa ou produz um "excedente", utilizado para o acúmulo (mas necessariamente para a sobrevivência).
} 
Na primeira empresa em que trabalhou, Fátima permaneceu por cinco anos. Ela conta que essa primeira demissão foi bastante dura - "Quando foi em 80 o setor no qual eu trabalhava na Motoradio foi transferido para Valinhos e eu fui transferida para outro setor da Motoradio. Aí, naquela época, eram mais ou menos 2000 funcionárias. Daí toda semana a Motoradio começava a dispensar pessoas, 60 por semana. Aí chegou a minha vez, porque o meu setor tinha eu e uma outra menina que estava grávida, uma das duas tinha que ser... então eu tinha certeza que não escaparia, ai eu chorei. Chorei três dias, quis morrer, achei que o mundo ia desabar. Aí, Deus abençoou que não demorou muito, fiquei dois meses e seis dias parada, naquela época não existia seguro-desemprego, não existia...Nos anos 80. Aí fui trabalhar na DAC88".

Após a dispensa, dois meses foram suficientes para que conseguisse outra colocação; a mudança de emprego se repetiu em 84 e levou também cerca de dois meses. Fátima começou então a trabalhar numa indústria de produção de imãs - a Erieis -, na qual permaneceu até 1996, só saindo devido à falência da empresa .

Fátima relata com saudade o período em que trabalhou na Erieis - "Eu tinha um emprego que eu amava, um emprego que nossa! Quando eu vestia a minha capa, da empresa, $e$ colocava o brochinho da CIPA, nossa! Não tinha problema, para mim, tudo para mim era aquela... (...) Se eu estivesse naquela (empresa) que faliu, como eu era uma ótima funcionária, sempre cumpri com meus deveres em tudo: não faltava, não chegava atrasada e não levava atestado... então eu era a funcionária dez! Se ela não tivesse falido, com certeza eu estaria até lá. Que era o meu sonho: quando completei 10 anos de empresa, nossa! Eu fiquei super feliz e agradeci a Deus; o meu sonho era completar 20, que completaria o ano que vem: era o meu sonho, dia 20/02 eu completaria 20 anos, que eu entrei no dia 20/02/84, em 2004 era os meus 20 anos de empresa, era um sonho que eu tinha. Mas infelizmente as ciladas da vida não deixaram que isso acontecesse e por isso eu não vou ficar me questionando o passado: o passado passou, agora vamos nos preocupar com o futuro".

Após a falência da empresa, foi com muita dificuldade (em suas próprias palavras) que conseguiu emprego numa indústria de componentes eletrônicos, com registro em carteira - "assim mesmo foi pouco tempo que eu trabalhei lá na Bitron. E assim mesmo, quando saí da Bitron, rebaixou o meu salário: eu saí da Erieis com $R \$ 3.076,00$ e

\footnotetext{
88 Vale relembrar que a legislação que estabelece o seguro-desemprego a partir do Fundo de Amparo ao Trabalhador é de 1990 (Lei 7998, de 11 de janeiro de 1990).
} 
entrei na Bitron com $R \$ 1.028,00 .$. De $R \$ 3.076,00$ para $R \$ 1.028,00$, olha a diferença...Isso o que? Em 1997. Diferença enorme. É assim, é complicado".

Porém, só ficou lá seis meses - foi dispensada. Desde a saída dessa empresa, trabalhou prestando serviço para gráficas, trabalho pesado e não registrado, ou então para oficinas de costura, como revisora, "tirando pelinho de camisa, essas coisas assim".

Entre 1996 e 2000, após o último trabalho registrado, Fátima transitou no mercado informal, portanto, prestando serviços quando havia trabalho a ser feito. Após a falência da gráfica na qual trabalhava, já tendo voltado a estudar, e pesando os prós e os contras de continuar trabalhando autonomamente, Fátima parou de procurar emprego em 2000, ainda que desejasse voltar a trabalhar: "voltei a estudar e era muito trabalho de escola e aí pensei assim "Ah, de repente eu arrumo um serviço longe e depois você vai dormir...". Porque quando eu trabalhava, eu levantava bem cedo, levantava às cinco da manhã e se eu tinha de marcar meu cartão 7h, às 6h eu já estava (lá). Eu nunca gostei assim chegar na última hora, chegar cansada, igual tem muitas que chegam - puf, pufeu não! se meu horário é sete horas, às seis horas eu chego lá, eu sento, eu converso, aí eu me troco, não é? Que sempre onde eu trabalhei a gente usava o uniforme, me trocava, quinze para as sete marcava o cartão, tomava o café e quando eu entrava para trabalhar eu estava super descansada, porque já tinha chegado há uma hora. Porque esse negócio de tomar o trem, tomar o ônibus, cansada, sair correndo, chegar faltando cinco minutos, se trocar correndo, não é comigo...Ai eu comecei a imaginar, e depois? Um monte de trabalho de escola, dormir meia noite e acordar às cinco da manhã, será que eu vou agüentar? Na minha idade, num pique assim? Também não procurei, não mandei currículo, descansei totalmente".

Quando nos encontramos, da primeira vez, em janeiro de 2003, tratava-se do momento em que ela recomeçara a procurar - "agora, essa semana passada (primeira semana de janeiro de 2003) é que eu saí, viajei passei o Natal e Ano Novo no interior, voltei, bati uns currículos, fui na Lapa, visitei as agências".

Quase um ano se passou antes que nos encontrássemos novamente. Porém, depois daquele dia da entrevista, feita no Centro de Solidariedade, ela não voltou mais a procurar emprego - "olha, se acontecer um emprego eu acho que seria pela misericórdia de Deus, agora, eu procurar, sair de casa todos os dias, todos os dias, todos os dias, não. (...)mas procurar mesmo em empresa, não; mandar currículo, eu mandei alguns em janeiro, fui na Lapa, distribui um monte de currículos, estive aqui, onde eu contei todo o meu 
passado, o da empresa e coisa e tal, empresa da qual até hoje não recebi, a empresa Erieis, mas procurar emprego mesmo, nãa".

Quando perguntada sobre as razões pelas quais não voltou a procurar emprego, Fátima respondeu: "é assim eu... não sei, se eu for procurar emprego eu acho que estou tirando a vaga de uma pessoa que talvez necessite mais do que eu, algum jovem, uma coisa assim. Talvez seja isso na minha cabeça, porque vontade eu tenho. Eu acho que a melhor coisa do mundo é você levantar às 5 da manhã, você sair e você achar que você tem um objetivo na vida, você tem um emprego, você vai trabalhar. É muito gostoso, o trabalho é a coisa mais importante da vida da pessoa. A pessoa que não tem emprego, ela não tem expectativa de vida. Eu penso assim".

A decisão de parar de procurar, no caso de Fátima, passou pela consideração de suas próprias possibilidades de encontrar um novo trabalho mas também pela constatação da situação geral do mercado de trabalho, que informa um modo de pensar o trabalho como um "bem”, uma riqueza que deve ser partilhada com justiça. Assim, emerge do relato de Fátima uma maneira de compreender o presente do mercado de trabalho que presume que os postos de trabalho (os que ainda existem) devem ser direcionados para aqueles que precisam trabalhar. Existe uma medida que distingue o que é justo ou não, que se manifesta tanto em discursos queixosos sobre a falta de oportunidades para pessoas mais velhas, supostamente com responsabilidades familiares, quanto nessa abdicação da procura. Aqui aparece, com clareza, a sua formação cristã, informando uma forma de compreender o mundo segundo os valores de justiça e partilha ${ }^{89}$.

Depois de uma vida de trabalho, em conjunto com o marido, Fátima conquistou algumas coisas, o que lhe permite desvencilhar-se da necessidade do trabalho - "na época do início do casamento, ele (o marido) falou assim, ele começou a implicar por causa do meu emprego e aí eu fui, e respondi, eu não dei o braço a torcer, "Entre você e o emprego, eu fico com o emprego". Ótimo, porque hoje eu sou parada mas pelo menos na época em que eu trabalhei, eu fiz meu pé de meia. Hoje, se aparece um emprego eu vou trabalhar, senão eu sobrevivo de aluguel, eu tenho um apartamento e a casa de aluguel. Então, na época em que eu

\footnotetext{
${ }^{89}$ Devo a observação da relação entre os valores que aparecem nessa fala de Fátima e sua formação cristã a Wilson Andrade, por ocasião da discussão deste capítulo em nosso Grupo de Estudos do Trabalho.
} 
trabalhava, eu fiz meu pé de meia. É isso que eu aconselho às pessoas: quando estão trabalhando, economizem, faz um pé-de-meia, porque não sabe do dia de amanhã. Se eu tivesse esbanjado todo o meu salário, e hoje? Como eu iria viver? Pagando aluguel... Com uma certa idade. Já eu não, eu pensei diferente, enquanto eu trabalhava, eu economizei e fiz meu pé-demeia".

É então que, contraditoriamente, embora continue tendo vontade de voltar a trabalhar e reconheça a importância do trabalho para a sua vida, ao "olhar para trás" e perceber que existem pessoas em pior situação, Fátima deslegitima o seu direito de reclamar e conforma-se com sua situação. Trata-se de uma forma de entender o trabalho não como direito, mas, como sublinhamos acima, como um bem, um privilégio, a ser desfrutado pelos que merecem ou pelos que têm sorte.

\section{A importância do emprego}

"A pessoa que é acostumada a trabalhar fora, para ficar parada é uma história complicada ficar dentro de casa...E eu sou assim, eu não sei ficar em portão de vizinho, eu não sei ficar na calçada, eu não sei o que é ficar na rua. Ou eu fico dentro de casa ou então tenho que estar fazendo alguma coisa". A ligação entre trabalho e atividade é a mais evidente nessa fala de Fátima: definir-se como "parada" foi algo que ela fez muitas vezes enquanto conversávamos, ainda que ao mesmo tempo reconhecesse a quantidade de atividades que tinha (as aulas de crochê e pintura, as aulas de pintura aos sábados, os encontros da Igreja) - "é um tédio, quem que agüenta? Parece que você, eu não sei, os dias não passam, as horas não passam. Que eu sou assim, apesar de que eu fiquei parada de trabalhar, mas eu fazia teologia no sábado, aqui na Pastoral de Santo Antônio, fiz o terceiro ano. Eu dava catequese, fazia informática, estudava na escola...".

É interessante notar a diferença entre essa situação de "estar parada", na definição de quem parou de procurar emprego, e a constante "correria" que aparece na fala de quem está procurando. A cessação de movimento parece caracterizar não a situação de desemprego, mas a desistência de tomar parte no mercado de trabalho é a assunção da inatividade, mesmo que esta seja involuntária e essa assunção é reveladora da dificuldade de construir outras atividades, outros eixos referenciais para a identidade. Definir-se como "parada", a despeito de reconhecer que se trata de 
um "parada de trabalhar", é reafirmar a centralidade do trabalho para a própria vida - o trabalho, o trabalhar é o ponto de referência a partir do qual ela se localiza socialmente.

A trajetória de Fátima não permitiria antecipar, pelo menos há alguns anos, que ela fosse deixar de fazer parte da População Economicamente Ativa antes de se aposentar:

"Sempre (trabalhei em indústria), em 75 eu entrei na Motoradio, na qual eu fiquei cinco anos, aí ela me dispensou; eu entrei na DAC, aí na DAC, quando ela me dispensou eu fiquei só uns poucos dias parada, foi só a conta de arrumar alguns documentos; aí eu consegui na Erieis, em 84. Naquela época era bom de emprego. Aí eu fiquei esse tempo até o dia 17, no dia 17/7/96 ela faliu, aí pronto! Começaram os problemas. Sabe quando você gosta de uma empresa, que você veste a roupa da empresa mesmo, que você coloca o crachá da empresa com prazer. Aí quando você perde, você acha que o mundo desabou em cima de você. Aí, mesmo assim, eu continuei procurando emprego, não desanimei. Trabalhei alguns meses na Bitron, em Alphaville. Hoje, ela está lá em Aldeia da Serra. Aí trabalhei pouco tempo e depois... eu falei "Quer saber de uma coisa? eu não vou trabalhar mais, vou estudar". Aí, voltei para as salas de aula, terminei o segundo grau, fiz informática...".

Não nos esqueçamos que, nesse período em que voltou a estudar, Fátima ainda fazia uns bicos, na gráfica ou na oficina de costura, não estando, portanto, "parada".

É a partir da falência da gráfica para a qual prestava serviço que renuncia à procura, temendo não poder se dedicar ao trabalho como sempre havia feito, mas temendo também não agüentar o pique necessário à conciliação entre trabalho e estudo. Por outro lado, o tipo de atividade que vai ocupá-la não está desprovida de um interesse voltado ao mercado de trabalho: o aumento da escolaridade e o curso de informática se constituem em competências reconhecidas como ampliadoras da empregabilidade. De algum modo, essas atividades ainda a vinculavam ao mundo do trabalho, constituindo-se numa estratégia de médio prazo já que, naquele momento, Fátima ainda vislumbrava possibilidades de retorno à atividade.

$\mathrm{Na}$ fala acima, ainda há alguns aspectos interessantes que merecem ser sublinhados. O primeiro deles se refere à coerência da trajetória de trabalho que Fátima vinha desenhando: tendo começado a trabalhar em indústria, mesmo sem 
escolaridade, as experiências que foi acumulando, todas registradas em carteira, garantiam a ela uma certa facilidade para conseguir um novo emprego; a partir do trabalho continuado, ela construía para si uma identidade profissional que dava sentido a sua trajetória. Quando perdia o emprego, ela não pensava em mudar de área - ao contrário, procurava se reinserir no trabalho industrial ${ }^{90}$.

A facilidade em encontrar um novo emprego na mesma área vai diminuindo ao longo dos anos e, reconhecendo que a crise é anterior aos meados dos 90, Fátima localiza em 1996 o ano em que "sentiu na pele" a dificuldade em encontrar um novo trabalho - "Até o ano de 1996 eu não sabia o que era o desemprego porque assim que eu saía de uma empresa, eu conseguiria em outra".

Antes, quando perdia o emprego, em seguida conseguia outro, mantendo sua função e o salário. A partir de 1996, a carteira assinada que funcionava como uma garantia de direitos e que era o signo de sua condição de trabalhadora, torna-se uma das razões que adia a sua volta ao trabalho - "em 96 nós tivemos uma grande dificuldade de arrumar emprego, não só eu como minhas colegas, que trabalhamos juntas no controle de qualidade. Na época, nós fomos barradas muitas vezes porque nós saímos com um salário alto e as empresas não rebaixavam o salário. Nós tivemos dificuldades mesmo".

A mudança do caráter da dificuldade fica mais evidente se acompanhamos o destino das colegas de trabalho: "Nenhuma (conseguiu emprego). Uma desistiu, vendeu o apartamento dela que ela morava na COHAB e foi embora para o interior. A outra...Nenhuma delas; nenhuma delas conseguiram emprego. Eu ainda consegui, na Bitron, seis meses, né? Registro em carteira. A Cida não conseguiu e foi embora para o interior, a Míriam era casada, até hoje nunca trabalhou, parece que depois arrumou um biquinho numa lojinha; assim, sem nada oficial, nada de registro na carteira. A Vera faz pão para vender, não conseguiu emprego

\footnotetext{
${ }^{90}$ Ainda que, em 77, tenha feito o curso de enfermagem, quando perdeu o emprego nem pensou em procurar nessa área: "fiz o curso de enfermagem em 77, recebi o certificado, fiz estágio no hospital São Lucas, em Diadema. Eu trabalhava durante a semana na Motoradio, à noite eu fazia o curso de enfermagem e aos sábados e domingos eu fazia estágio lá no hospital São Lucas. E era aquela correria, aquele monte de doente e eu aplicava injeção e estava aprendendo. Quando eu terminei de fazer o curso, que eu recebi o certificado, era eu e uma colega, a colega pediu acordo na Motoradio e foi trabalhar no hospital São Lucas, que iria contratar a gente. Nós éramos estagiárias, trabalhávamos lá. Eu tenho as fotos até hoje. Na época, eu tinha de pedir a conta na Motoradio, abaixar o meu salário para ir trabalhar no hospital São Lucas, enfermagem também é uma coisa que eu não gostava, meu negócio eram peças. Aí eu comecei a pensar, "Eu não vou fazer isso, eu não vou trabalhar com enfermagem".
} 
também, sobrevive fazendo pão. E...ah, não sei, assim...A Lenira costura para sobreviver, mas assim, emprego oficial mesmo, de todas que trabalhavam comigo, nenhuma conseguiu".

Não é possível deixar de assinalar a "feminilidade" dessas narrativas de não retorno ao mercado de trabalho. As colegas de trabalho - todas mulheres, o que nos permite pensar sobre o caráter do trabalho feminino na indústria - , após perderem o emprego no mesmo momento em que Fátima, não conseguiram voltar a ter um "emprego oficial", algumas transitando para a inatividade (e é interessante notar como Míriam, casada, transita com mais facilidade), outras transitando para a informalidade ou, como Vera e Lenira, "virando-se" a partir de uma atividade tipicamente feminina ${ }^{91}$.

Já na primeira entrevista, a constante afirmação da importância do trabalho em sua vida era algo que chamava atenção na narrativa de Fátima - uma importância que aparecia em sua impaciência em permanecer em casa, na insistente saudade que sentia do uniforme, no esforço por ocupar seu tempo de outras maneiras... ${ }^{92}$

Uma das explicações encontradas por Fátima para a sua forte relação com o trabalho está ligada aos trabalhos que fazia quando jovem, ainda no interior de Minas Gerais: “Cheguei do interior, pensei o seguinte...Eu sempre gostei de trabalhar, até hoje eu não sento, assim, se eu sento ou eu tenho que estar lendo; se eu vou assistir televisão tenho que estar lendo ou fazendo crochê, a mão tem que estar movimentando e a mente também por que se ausentar assim, parada, parece que a mão formiga, eu não sei o que acontece. Eu acho que é porque eu cresci trabalhando, trabalhava na roça, então acho que isso atingiu muito a minha expectativa de vida".

Outra razão apontada por Fátima para esse gosto pelo trabalho se refere aos laços criados no ambiente de trabalho: "eu me recordo que muitas vezes, às sete da manhã, aquele lote de peças deveria estar no estoque. Aí, nosso chefe que é o senhor Breno, chamava "Dona Maria, venha aqui. A senhora pode entrar amanhã às 6h? Porque às 7 esse lote tem

\footnotetext{
${ }^{91}$ Sobre as trajetórias de operárias após a demissão de um emprego industrial, ver Hirata e Humphrey (1989a).

92 Talvez seja necessário relativizar essa constante reiteração devido à situação de entrevista. Afinal, o tema da entrevista era o desemprego e sua história de trabalho e a entrevista se deu num espaço de procura de emprego. Assim, não é desprovido de sentido pensar que isso delimita um campo de discurso, trazendo para a frente da cena tanto o gosto pelo trabalho quanto a vontade de voltar a trabalhar. Observe-se, mais uma vez, que reconhecer isso não significa "desconfiar" da veracidade do relato, mas realizar o esforço por reconhecer a realidade social que este circunscreve.
} 
que estar na empresa ", e eu "Sem dúvida". Cinco e meia eu estava lá: a empresa trabalhava dia e noite! Sete horas já estava aprovado no estoque. Isso, para mim, não era dúvida. Trabalhar de sábado, meu Deus, era o maior prazer da minha vida. Quando um sábado, hora extra, era muito bom. Era muito bom. Porque eu vejo assim também: quando você trabalha há muitos anos numa empresa, parece que você forma uma família dentro da empresa. Igual, no meu caso, eu vivia mais dentro da empresa do que na minha casa. Então, as amigas de trabalho, para mim era como se fosse uma família. A gente se dava bem, se unia; agora, no fim do ano, fazia uma confraternização, brincava de amigo secreto...Então, é uma coisa muito marcante, que sempre marca a pessoa. É muito gostoso quando você trabalha num ambiente em que você se sente bem. Agora, quando você trabalha num ambiente em que tem aquelas pessoas que fazem confusão, que brigam, aí é desagradável. Só que eu nunca tive esse problema, graças a Deus, aonde eu trabalhei sempre parecia que era uma família".

É possível perceber como o compromisso com o trabalho, com a empresa, está ligado às relações que se estabelecem lá dentro. Não se trata de uma obstinação de "Caxias", abrindo mão de todas as coisas em nome do trabalho pois que o compromisso com a empresa está inteiramente mediado pelo sentido que ela enxerga no trabalho. Se trata, portanto, do reconhecimento da importância que o emprego ocupa na sua vida, tanto em relação à ocupação de seu tempo ("eu vivia mais tempo na empresa do que na minha casa") quanto em relação aos laços de sociabilidade que se tecem lá dentro. É isso que dá sentido à responsabilidade que se tem com o trabalho.

Na história de Fátima, o compromisso com o trabalho e o esforço por se aproximar do que ela considera ser um empregado exemplar parece ser uma constante. Como fica evidente quando ela descreve as razões que a levaram a adiar a volta à escola:

"Por que eu sempre quis voltar a estudar. Como geralmente eu fazia hora extra, geralmente para mim sempre empresa em primeiro lugar. Casa, divertimento, festa: segundo plano. Marido, terceiro plano. Sempre a empresa em primeiro plano e para eu voltar a estudar eu não poderia fazer hora extra. Se bem que a empresa dava todo o apoio para aquelas pessoas que trabalhavam e estudavam: elas saíam mais cedo, antes de saírem a empresa fornecia um lanche. Para isso, a empresa era dez, ótima...Só que eu pensava assim, a minha hora extra é mais importante, porque sempre para que quando alguém falasse para mim "Dona Maria, a 
senhora pode ficar até sete para terminar o serviço?", "Posso ficar até às dez, quanto mais até às sete", então para mim sem problema. Eu só voltei a estudar quando parei de trabalhar (...)".

A dedicação ao trabalho não se dá, desse modo, sem conflitos, sem implicar no adiamento de planos e desejos. O que chama a atenção é que, em nenhum momento, esse adiamento parece não valer a pena: só quando perde o emprego, só quando o que encontra é o trabalho na gráfica, pesado, irregular, sem ser "oficial" é que Fátima, ao pôr as coisas na balança, verifica que o esforço não vale a pena.

Estou chamando a atenção para esse aspecto porque ele revela um importante deslocamento em relação aos significados do emprego e da importância do trabalho. O relato de Fátima nos sugere que, menos do que a importância "moral" do trabalho - sugerida por uma cultura do trabalho, para recuperar os termos de uma de nossas discussões centrais - é o imaginário do emprego que opera como o vínculo entre Fátima e seu trabalho, informando suas escolhas e decisões, impactando sobre sua disponibilidade para o compromisso e a assunção de responsabilidade com uma empresa. O vínculo formal, e tudo o que ele implica e acarreta, aparece como a contrapartida da disposição em "vestir o uniforme", "vestir a camisa" da empresa.

Não é à toa que Fátima não chega a afirmar que as relações estabelecidas dentro da empresa são de tipo familiar. Ela tece a comparação, mas marca sua diferença: parece uma família, é como se fosse uma família. Mas não é, pois que o vínculo que se estabelece é de outro tipo e sua continuidade está ligada à continuidade do contrato de trabalho. Sem este, o compromisso se desfaz, abrindo espaço para que critérios exteriores ao mundo do trabalho operem na avaliação do que vale ou não a pena. Fátima expressa, assim, a consciência crítica de que, à diferença dos laços familiares, assentados sobre a consangüinidade e por ela garantidos, os laços contratuais estão sempre sob o risco da ruptura - mesmo que haja registro na carteira. E é impossível determinar se tal consciência podia emergir durante o período em que ela estava empregada ou se trata-se de uma crítica posterior, possibilitada justamente pela experiência prolongada do desemprego ${ }^{93}$.

\footnotetext{
${ }^{93} \mathrm{~A}$ atenção que estou chamando sobre essa maneira encontrada por Fátima para expressar as relações que teceu no espaço da empresa se justifica pelo fato de que, ao matizar as afirmações, ao relativizar dicotomias ou ao demonstrar a consciência das insuficiências explicativas dos discursos de que lançam mão, os entrevistados põem em evidência o tipo de "estruturas cognitivas" de que são
} 
É claro que não se trata de uma regra geral: essa análise vale para uma trajetória como a de Fátima, de alguém que sempre esteve inserido no mercado formal de trabalho e, dentro dele, no setor industrial - trabalhando em empresas médias e grandes. E o que temos aqui é uma trajetória na qual o emprego aparece como uma categoria central, tanto para a construção de uma identidade profissional quanto para a significação do trabalho e das outras atividades da vida.

Como vimos, não se trata de um processo coerente ou de uma trajetória linear: Fátima oscila todo o tempo entre a valorização do trabalho (tendo como referência principalmente o emprego) e a valorização das atividades que desenvolve hoje, a partir da consciência de que o (seu) mundo do trabalho mudou. Ao mesmo tempo, o prolongamento de sua situação de desemprego (utilizando-se aqui o termo sem qualificação quanto ao tipo de desemprego e ainda que alternado com períodos de inatividade), faz com que os critérios de análise também se modifiquem.

Na primeira entrevista, Fátima dizia que o trabalho em gráfica não valia a pena, por ser pesado, irregular, etc. Já na segunda entrevista, quase um ano após a primeira, Fátima dizia "E hoje é porque eu não encontro, se eu encontrar uma gráfica que me chame, para eu prestar serviço, com toda a agilidade...(...) volto, não olho nem de lado".

Importante deslocamento no modo de entender as suas próprias possibilidades e limites frente às mudanças.

\section{O trabalho e a apropriação do espaço}

Outro aspecto que chama a atenção no relato de Fátima se refere à relação que estabeleceu com os bairros industriais de Osasco e da zona Oeste de São Paulo94. Recordando-se de quando andava pela Vila Leopoldina (zona Oeste), aparece o sofrimento pelo desaparecimento das fábricas, do movimento dos funcionários. Sofrimento também pelo desaparecimento de um modo de viver e trabalhar, pois

portadores, revelando muito da experiência do trabalho que tiveram (para uma discussão sobre a formação e os significados das estruturas cognitivas reveladas nas narrativas de operários e operárias, ver Rodrigues, 1978, p.119 e seguintes).

94 È interessante relembrar que a cidade, como palco sobre o qual se projetam as percepções da mudança, também aparece na narrativa de José, tanto quando compreende a cidade como o lugar das ilusões quanto ao observar o excesso do centro urbano como sinal de que a cidade já não comporta mais a presença de tantas pessoas, que necessitam de trabalho. 
mesmo as empresas que ficaram, ainda que continuem produzindo, agora o fazem com menos funcionários. Tudo ficou deserto:

"Se você for na Leopoldina - eu falei isso na primeira entrevista - você chora: pavilhão e pavilhão abandonado. Está o pavilhão da Erieis abandonado, o depósito da Mappin, que também tinha, enorme, trabalhava mais funcionários, tinha aquela fábrica de pneus, totalmente abandonada também, você chora. "Aluga-se", ninguém aluga. Você anda quarteirões e quarteirões e parece um deserto. Eu não gosto de ir na Leopoldina, eu choro de ver tanta... ;(..)O prefeito de Alphaville deu dez anos sem imposto, então quantas empresas daqui foram embora para Alphaville ${ }^{95}$ ? Claro... só de gráficas que tinha ali na Barra Funda, muitas delas foram embora, estão em Barueri. Aí eles contratam, geralmente, quem mora em Barueri porque eles moram perto, pagam uma condução só. A maioria das empresas não quer esse problema, assim, de desembolsar o dinheiro de vale-transporte em duas conduções, é uma só. Geralmente, quando ela vai contratar os funcionários, ela quer saber aonde o funcionário mora e quantas conduções toma. Se forem duas... ele dá preferência para quem toma uma só ou quem mora perto, quem não paga o vale-transporte. Tanto da Leopoldina quanto da Barra Funda e de outros lugares aqui, aqui em Osasco mesmo, quantas empresas de Osasco não foram embora? A Eternit, só ali na Autonomista, ali trabalhavam mais de 10.000 funcionários: tinha a Eternit, a Santista, a Brown-Boveri, a Lonaflex, todas elas foram embora. Agora tem o quê?? A faculdade e a agência de carros e o Carrefour, o Wal-Mart, que também empregam bastante funcionários".

A circulação pelos espaços de trabalho inseriram Fátima de uma determinada maneira na cidade, tornando-a mais sensível para o caráter das mudanças em curso no mundo do trabalho. A lembrança do período em que as indústrias tinham muitos funcionários e funcionavam a todo vapor se inscreve em sua maneira de olhar os fatos e de interpretá-los.

A imensa quantidade de funcionários, entrando, saindo, cumprindo o ritual da ida e da volta do trabalho, é entendida como uma prova de que se está produzindo, de que as coisas estão indo bem. O esvaziamento, afinal, não é repentino: uma a uma, as fábricas e empresas vão deixando a região, seja por terem falido, seja por estarem à

\footnotetext{
${ }^{95}$ Fátima se refere aqui ao prefeito de Barueri, município no qual os condomínios Alphaville se localizam.
} 
procura de um local com cobranças de impostos menores e onde seja possível pagar salários mais baixos ${ }^{96}$.

Assim como Fátima aponta no caso do vale-transporte - que as empresas procuram evitar pagar, para isso empregando apenas moradores da região mais próxima - as empresas não têm compromissos com a região. $\mathrm{O}$ resultado é um deserto, inúmeros galpões vazios; na Vila Leopoldina, as linhas de trem não servem mais ao transporte das pessoas para o seu trabalho - ninguém mais desce ali, ninguém mais passa ali. Na Avenida dos Autonomistas, em Osasco, apenas grandes supermercados, revendedoras de carro, escolas de línguas ou de informática, universidade e, mais recentemente, grandes lojas de material de construção. Fátima aponta que eles também contratam vários funcionários. Porém, trata-se de um tipo muito diferente de emprego, em outro setor de atividade econômica que não o industrial, que provê um "mínimo diferente" (conforme o relato de Suely tratará de esclarecer).

Perguntei a ela se conseguia localizar um momento a partir do qual a situação do trabalho começara a se complicar e ela me respondeu a partir da descrição de uma situação:

"Então, eu acho que um pouco, o desemprego, foi a tecnologia, e outro pouco também por causa do governo, do presidente. Porque você se recorda quando a Mafersa queria produzir as peças de trem, ele deixou de dar as peças da Mafersa e importou da Alemanha? Fernando Henrique fez isso; o que aconteceu? A Mafersa fechou, faliu e a maioria das empresas também. Ele não deu o serviço, que ele deveria ter dado o serviço para a mão de obra brasileira, vamos ajudar os brasileiros, o que é que ele fez? As peças vieram da Alemanha, os trens novos, a peça não é brasileira, não é original daqui, vieram da Alemanha. Gente, por que

\footnotetext{
${ }^{96}$ A percepção de que as empresas tendem a não tecer relações com o local onde estão instaladas é dos um dos fatores que alimenta a discussão sobre o desenvolvimento local, que tem entre suas preocupações - em que pesem as variações de perspectiva dos vários atores que fazem uso do conceito - estimular a cultura de que as empresas que se instalam em um determinado território passam a ter responsabilidades em relação a ele. Trata-se do esforço por encontrar novas formas daquilo que Karl Polanyi chamou de embededness, ou seja, o enraizamento das empresas nos espaços e e nas relações por eles circunscritos; enraizamento que opera como freio à utilização de quaisquer meios para obtenção de lucros crescentes, evitando que situações como as descritas por Fátima cheguem a acontecer. Cf. Polanyi, (1980).
} 
é que ele fez isso? Por que que ele não deu o serviço para a Mafersa, deixasse produzir aqui no Brasil, não é isso? Vamos valorizar o trabalho brasileiro".

Já na primeira entrevista, Fátima atribuiu o agravamento da situação do emprego às práticas do governo Fernando Henrique Cardoso - "O Fernando Henrique acabou com o Brasil". A partir de sua fala, porém, principalmente a partir da situação que ela toma como paradigmática das razões para a piora da situação, é possível perceber que ela se refere à abertura econômica, continuada por Fernando Henrique Cardoso (a partir de 1994) mas iniciada por Fernando Collor de Mello, em 1990. Ainda assim, essa fala sugere que há pessoas e ações a serem responsabilizadas pela situação atual - e se sublinho que é possível depreender isso de sua fala é porque, quando se trata de reverter a situação, para melhorá-la, Fátima não enxerga outra possibilidade que não a misericórdia divina. Se são ações humanas que levam aos problemas, superá-los parece tarefa sobre-humana.

Interessante também é que Fátima reconhece algumas das razões que justificariam a abertura econômica, entre elas o estímulo à competição e o barateamento dos produtos. Nem por isso considera a abertura justificada, pois que as conseqüências para as indústrias e para o trabalho são desastrosas: todas as empresas nas quais trabalhou, desde que se mudou para São Paulo, faliram, a partir do final dos anos 80. A única exceção é a Bitron, empresa na qual permaneceu por seis meses, entre 1996 e 1997.

Ao contar o caso da Mafersa e da importação de peças que estavam sendo produzidas aqui, o tom de Fátima era de inconformação ${ }^{97}$. Sua voz elevou-se, seu corpo se agitou; ela parecia pessoalmente atingida com a decisão de Fernando Henrique. Por mais que fosse capaz de ponderar e compreender as razões que o levaram a tal decisão, era incapaz de compreender que outros critérios não tivessem sido levados em conta.

\footnotetext{
${ }_{97}$ A Mafersa - fabricante de vagões ferroviários e de metrô - é uma ex-estatal, das primeiras a serem privatizadas, durante o governo Collor (1991). Faliu em 1996, quando foi assumida por uma cooperativa de trabalhadores (engenheiros). Continuou funcionando, após diversos cortes e demissões, até ser vendida para a multinacional GEC ALSTHOM, que fechou a unidade que funcionava em São Paulo.
} 
No entanto, o que sobressai nessa fala é a maneira de se referir ao presidente do país, muito similar à maneira com que as pessoas em desemprego aberto se referem, de modo indistinto, ao governo (sem qualificação de instância), às agências de recolocação profissional e aos empresários. A todos eles se identifica algum grau de poder de decisão sobre questões que afetam diretamente a vida dos trabalhadores e, assim, seus representantes são considerados como os responsáveis maiores pelas conseqüências. $\mathrm{O}$ que parece bastante contraditório pois que significa conciliar um modo de compreender o mundo que, ao mesmo tempo, atribui culpa ou responsabilidade a pessoas quando se trata de identificar as razões que levam a crises e considera as possibilidades de superação para além da esfera das ações humanas.

Na primeira entrevista, Fátima disse que desconfiava que fosse "pé-frio", pois todas as empresas em que trabalhara haviam falido. Mais fecundo para a explicação do que a má sorte de Fátima, no entanto, é o reconhecimento da crise do setor industrial, agravada tanto pela abertura econômica quanto por um período continuado de baixas taxas de crescimento ${ }^{98}$.

"Eu choro, quando eu entro ali na Leopoldina, que eu ando, quarteirões e mais quarteirões, totalmente fechados. Ali, seis da manhã, quando você tomava o trem, era um batalhão de gente que descia, que dava medo. Era um empurra-empurra. Hoje...Toma o trem para você ver; eu tomo o trem para mim observar. Eu fico pensando assim: cadê os funcionários? Cadê os trabalhadores? Cadê? Você conta as pessoas que descem. Ali na (Avenida) Mofarrej, nesse horário de seis horas, era um batalhão de gente, que aí você não andava sozinha, era uma multidão de gente que descia, eram as empresas dos dois lados. Hoje em dia só tem a Columbia e diz que tava para falir, não sei se faliu ainda".

A relação com os espaços de trabalho da cidade, portanto, e a observação de suas mudanças (de terrenos vazios para um parque industrial, de parque industrial para galpões vazios, de galpões vazios para grandes supermercados ou empresas prestadoras de serviços) é reveladora da dinâmica do trabalho e contribui para o modo de compreender e interpretar as mudanças que tiveram lugar no mundo do trabalho e, conseqüentemente, na cidade que se organiza a partir dele.

\footnotetext{
98 Entre 1989 e 2001, a taxa média de crescimento econômico foi de 2,07\% ano. Há que se levar em conta, também, que houve anos de crescimento negativo (1990 e 1992) e anos de crescimento inferior a 1,0\%(1998 e 1999). Segundo dados do IPEA, www.ipeadata.gov.br.
} 


\section{Vestindo a camisa: a importância do uniforme}

Durante a primeira entrevista com Fátima, a recorrência de uma fala sua me chamou muito a atenção, assim como a ênfase que ela deu ao assunto: trata-se do uniforme que ela usava para trabalhar.

"Eu tinha um emprego que eu amava, um emprego que nossa! Quando eu vestia a minha capa, da empresa, e colocava o brochinho da CIPA, nossa! Não tinha problema, para mim, tudo para mim era aquela..."; "Eu sonho que estou trabalhando, vestida na capa da Erieis, que até 2000, quando eu trabalhava na gráfica, era o maior barato, quando a BM estava precisando de muitas pessoas, então a gráfica, a nossa - a Max Serv - mandava nós trabalhar para lá, aí nós ficávamos 15 dias, uma semana, duas semanas, lá na Aldeia da Serra. Tinha um ônibus que pegava a gente e trazia. Aí eu vestia o uniforme da Erieis, que eu tinha perfeitinho, os três uniformes, três capas, três calças e eu vestia o uniforme, ai que felicidade...Eu sonho. Eu tenho minhas três calças e minhas três capas, perfeitinhas, o meu crachá e eu tenho dois brochinhos da CIPA, que eu era da CIPA".

A Comissão Interna de Prevenção de Acidentes - CIPA, estabelecida em seu modo de funcionamento atual pela Lei 6514/77, é composta por representantes dos empregadores e também dos empregados. Os representantes dos empregados são eleitos, em votação secreta, para mandatos de um ano (sendo possível a reeleição). Além disso, os membros da CIPA gozam de estabilidade durante o período de seu mandato e 12 meses após o seu término. Trata-se, assim, de uma forma de participação e, portanto, não é à toa que Fátima identifica a sua participação na Comissão à participação sindical: "eu fui sindicalista. Na Erieis eu era, participava sim. (...) sobre o desemprego não (discutiam), das máquinas não. A gente nunca discutiu a isso porque as nossas reuniões eram mais assim, como eu, a primeira vez que participei do sindicato eu era suplente, era a favor da empresa. Então eu verificava se os funcionários estavam correndo o risco de perigo: eu não deixava que ninguém trabalhasse sem protetor de ouvido, sapato de segurança, até formava atritos dentro da empresa. (...) andava na empresa nos meus horários de almoço, verificava e se alguém estivesse trabalhando sem protetor de ouvido, eu corrigia; se alguém não estivesse com o uniforme adequado, faltando sapato, eu chegava na pessoa e conversava, não assim com brutalidade, entendeu? Conversava com pessoa. Se eu percebesse que a pilha estava mal empilhada, corria o risco de cair e machucar 
alguém, nos momentos assim de ocorrer algum acidente, eu conversava com a pessoa... (...) Então quando sindicato vinha, tinha reunião uma vez por mês e assembléia, tinha ata, aí questionávamos os problemas da empresa e coisa e tal, então eu participava das reuniões".

$\mathrm{Na}$ Erieis, foi a primeira vez que ela participou de alguma maneira do processo de discussão e de tomadas de decisões relativas ao trabalho, tendo a oportunidade de experimentar uma participação diferente do simples trabalhar - "só na Erieis. Aí quando tinha eleição, todo mundo votava em mim. Por que o pessoal "Eu quero espelho no banheiro", aí eu dava um jeito; "Quero isso pro banheiro", eu dava um jeito. Sempre era assim". As relações tecidas com os outros trabalhadores, mesmo que envolvendo conflitos de interesses pela defesa de práticas recusadas por eles (tais como o uso dos Equipamentos de Proteção Individual), inseriu Fátima num tipo de experiência de negociação e resolução de problemas que, muito provavelmente, está na origem da acuidade de sua compreensão das mudanças no mundo do trabalho ${ }^{99}$.

A consciência de estar identificada aos valores da empresa aparece, então, iluminando melhor o reiterado gosto pelo uniforme, expresso por Fátima diversas vezes. Na segunda entrevista que fiz, perguntei a ela sobre o uniforme e ela reiterou sua importância:

“ Nossa! Gente, realmente... eu tenho meu uniforme guardado, meu crachá e meu uniforme, eu não me desfiz, da Bitron eu também tenho. Era o maior prazer, vestir o meu uniforme. (...) Eu gostava, da calça e da capa... E as meninas, elas tinham uma mania: elas iam no banco, elas se trocavam. Elas tinham vergonha de chegar lá: porque inspetoras de qualidade, trabalhar com ímãs, a capa branca... você acha que não sujava? Eu não, entrava no banco com a capa suja e não estava nem aí! Nunca me troquei para ir ao banco. Eu tinha o maior prazer, se eu tinha algum problema, assim, na hora do almoço, pedia saída, um problema para eu ir e voltar, eu ia de o uniforme, eu não me trocava, do jeito que eu saía, eu marcava o cartão e ia resolver o problema com a mesma roupa. E às vezes também de sextafeira, eu também não me trocava: do jeito que eu saía, pegava o carro e ia embora. Chegava em casa com o uniforme. Agora, as meninas criticavam "Eu não saio com essa roupa para lugar nenhum", eu falava "Eu vou em qualquer lugar, vou em banco, de sexta-feira vou embora com

\footnotetext{
${ }^{99}$ A noção de experiência a qual me refiro é a que pode ser apreendida a partir de Thompson, quando trata da formação da classe operária inglesa (Thompson, 1987).
} 
minha roupa, não me troco, vou embora com ela, chego em casa tranqüila. Aí chegando em casa é que vou tomar banho e tirar a minha roupa".

Parece claro que grande parte do prazer sentido por Fátima ao usar o uniforme das empresas nas quais trabalhava se deve ao seu significado simbólico, de pertencimento a uma empresa. O uniforme a inscreve no cotidiano do trabalho e, de algum modo, a diferencia em relação a outras pessoas. Ir ao banco de uniforme, na hora do almoço, significa ter uma ocupação, ter que aproveitar os intervalos do trabalho para resolver os problemas particulares: é a marca do trabalho. Nesse sentido, ele opera uma distinção entre os que trabalham e os que não trabalham.

As colegas de Fátima, "as meninas" - e novamente deve-se notar como essa companhia é sempre feminina - rejeitam o uniforme. Fátima atribui essa rejeição a um "tipo de complexo", devido à sujeira. Mas podemos imaginar que esta rejeição ao uniforme também tem como razão o seu duplo caráter: ao mesmo tempo que opera distinções, também produz indiferenciação pois passam todas a ser funcionárias de uma empresa; deixam de ser indivíduos. O uniforme aparece, assim, como a inscrição da condição de trabalhadoras, ademais, afirmando o lugar que ocupam na estrutura produtiva.

Ao longo da entrevista, Fátima foi preenchendo de outros significados essa importância que atribui ao uniforme. Ao falar sobre os jovens e a falta de compromisso que têm com o trabalho (ver, em mais detalhes, as páginas seguintes), Fátima ressignifica o "vestir o uniforme", aproximando-o da idéia de "vestir a camisa", assumindo as responsabilidades do trabalho, colocando-o em primeiro plano. Ainda, ao se lembrar do curso de enfermagem que fez, em 1977, disse que não trabalharia em hospital, a não ser como voluntária:

"Foi bom que eu fiz o curso, porque se eu não tivesse feito o curso, talvez eu pensasse "Ah, que eu vou tentar, talvez..." , mas não, tem que fazer aquilo que você gosta. Eu não gostei trabalhar na saúde, esse serviço de enfermagem eu não gostei. E a minha colega foi trabalhar, hoje ela trabalha no Hospital das Damas, como enfermeira - e eu não quis trabalhar em enfermagem. Aprendi sim, hoje se for para eu fazer um curativo numa pessoa eu faço, faço um curativo, meço uma pressão, tanto com o aparelho quanto o...O coração, eu tiro as medidas do coração, se for para fazer um curativo em qualquer pessoa eu faço. mas para mim trabalhar 
num hospital, vestir o uniforme de um hospital, tsc, tsc, tsc. Vestir o uniforme para mim só de uma empresa, por que de hospital não. Só se for para eu cuidar, assim, de um doente, medir pressão, até voluntário, se precisar, não olho duas vezes, não penso duas vezes, eu vou. agora, trabalhar no hospital, vestir o uniforme do hospital. Quando falo para você vestir o uniforme do hospital, vestir o uniforme de uma empresa é você trabalhar, é você vestir o uniforme e trabalhar. Aí não...".

O uniforme como um símbolo de pertencimento a uma empresa e, por extensão, ao mundo do trabalho aparece também nas falas sobre a rotina durante o período em que estava empregada:

"No fim de semana, eu tinha os uniformes para lavar, o meu e do meu marido. Depois que a empresa faliu e que eu parei de passar, de lavar aquele uniforme... Nos domingos à noite eu passava uniforme. Nossa! Eu estranhei um tempão! Quando eu ia passar a roupa, cadê o uniforme? Eu ia lavar roupa, cadê o uniforme? Eu tenho os dois guardados hoje, tanto o crachá quanto o uniforme".

Símbolo do trabalho, para além do período vivido dentro da indústria, a interrupção do uso do uniforme, a exemplo do esvaziamento dos bairros industriais, também apóia o sentimento da mudança: cadê os funcionários? Cadê o uniforme? Onde foram parar todos estes aspectos da vida que se tinha como certos?

Ainda que a constante referência ao uniforme se trate apenas de uma expressão, um modo de dizer, não é possível deixar de reconhecer que se trata de uma forma que revela incompreensão e estupefação diante de um presente que é bastante diferente daquilo que já se viveu. Como Fátima mesmo disse: o passado é passado, agora é preciso encarar o presente e o futuro; mas essa é uma tarefa difícil quando as categorias de que se dispõe para pensar permanecem as mesmas, a despeito do esforço realizado para alargá-las.

\section{Poupança, previdência, seguridade: construir as garantias para o futuro}

É importante ressaltar, ainda uma vez, que a situação de Fátima não é uma situação típica - ela pôde prescindir de trabalhar por dispor de uma casa e um apartamento, comprados durante seu tempo de trabalho. Sendo assim, o trabalho aparece, para ela, como algo desejável, mas não necessário, no sentido de estar em 
jogo a sua sobrevivência e a de sua família. Além disso, por não ter filhos, nem durante a vida de trabalho nem atualmente, não houve despesas com a criação e a educação de crianças - o que libera grande parte do orçamento doméstico ${ }^{100}$.

Olhando retrospectivamente, Fátima reconhece em seu trabalho a possibilidade de conquistar essas garantias para o futuro:

“Então, na época em que eu trabalhava, eu fiz meu pé de meia.(...) Hoje, graças a Deus, não: eu não pago aluguel, eu recebo aluguel. Por mais que às vezes tenha algum probleminha com o inquilino, mas isso aí é normal".

O comedimento na condução da economia doméstica é um traço importante na fala de Fátima, pois revela uma espécie de ascese em relação aos frutos do trabalho:

"Porque telefone é muito bom mas você tem que saber usar. Eu economizo tudo na minha casa, tudo. Eu economizo desde a água, luz, tudo, eu procuro economizar. Para que não falte o essencial. (...) Hoje eu recebo meu aluguelzinho e dá para eu sobreviver, levar uma vida de classe média, mas simples. Como eu sempre economizei, sou acostumada a economizar, com pouco dinheiro eu sobrevivo. E se tivesse gastado todo o meu salário? Roupas, luxos, passeios, vaidades...E hoje?".

Há alguns aspectos importantes nessa fala. O primeiro deles se relaciona ao sentido que se atribui ao trabalho: Fátima não trabalhava para enriquecer ou para ser capaz de esbanjar. Seu trabalho tinha por objetivo ser capaz de levar uma vida confortável, digna, simples. Outro aspecto importante é a sua filiação à classe média, ainda que "simples".

O último ponto que sublinho é que essa ética poupadora que aparece na fala de Fátima, que projeta a realização da independência para o futuro, pode ser interpretada como uma possibilidade aberta pelo vínculo formal com o trabalho. A perspectiva de continuidade, oferecida pelo registro em carteira e que, chamei a atenção anteriormente, está relacionada à importância que Fátima atribui ao trabalho desfaz a relação imediata entre trabalho e consumo. Em termos arendtianos, a mediação da cultura do emprego permite transformar em trabalho aquilo que, de outro modo,

\footnotetext{
100 Os gastos com educação tem aumentado nos últimos cinqüenta anos. No início da década de 70, eles ocupavam em torno de $4 \%$ do orçamento doméstico, em $82 / 83$ já chegava a $5 \%$ e em $94 / 95$, tais gastos passam de $6 \%$ do orçamento, conforme dados da Pesquisa de Orçamento Familiar - POF (DIEESE, 1995).
} 
permaneceria sendo labor. É assim que os frutos do trabalho de Fátima não foram apenas destinados ao consumo, mas à produção de um futuro mais estável e de segurança.

Trata-se, como se verá adiante, de uma estratégia completamente diferente daquelas utilizadas por Suely, para quem o trabalho, no início de sua trajetória, é consumo (seja de produtos necessários à sobrevivência, seja de "supérfluos" que ela vincula aos cuidados tipicamente femininos com a casa e os filhos). Apenas após a separação, portanto após se tornar a chefe da família, é que Suely se vê interpelada a construir estratégias que tenham o futuro como horizonte e que a tornem menos vulnerável às oscilações do mercado de trabalho. É então que os frutos do trabalho realizado no presente passam a ser transformados em poupança para a construção da casa própria ou para a sua requalificação profissional ou para o investimento na educação dos filhos - tratam-se também de estratégias para a construção de garantias contra a instabilidade dos trabalhos disponíveis. A projeção de um futuro melhor funciona, assim, como mediação que torna possível a transformação do labor em trabalho, não porque mude o conteúdo do trabalho, mas porque muda o sentido que se atribui a ele, muda a durabilidade das coisas que ele produz.

Ao contrário de outros entrevistados que chamavam a atenção para o fato de serem pobres e, por isso, precisarem trabalhar todo o tempo, até o fim da vida, conquistando lentamente as coisas com muito custo, Fátima expressa, ao se reconhecer como parte daquilo que chamou de "classe média simples", a consciência da mobilidade social possibilitada pelos anos de trabalho. Como muitos, ela chegou aqui sem estudos, sem profissão. Mas, ao longo de sua trajetória, acumulou experiências, constituiu uma identidade profissional e, hoje, está em outro lugar.

É interessante notar que tal mobilidade foi possível por meio de uma estratégia familiar de acumulação. O marido de Fátima era o responsável pelas despesas da casa; o dinheiro que ela ganhava - excedente - é que pôde ser poupado:

"Eu guardava, eu sempre guardava. Eu guardava todo o mês, minhas férias. Eu viajava, mas uma boa parte eu guardava. Eu guardava duas vezes: no vale e no pagamento. Ele (o marido) pagava a luz, pagava telefone. As despesas da casa eram com ele e eu guardava. Roupa, sapato, essas coisas, como eu sempre trabalhava e usava o uniforme da empresa, então 
não tinha como gastar muita roupa! Só para ir e voltar? Eu sempre guardava e aí é onde foi construindo alguns beneficios para poder sobreviver agora".

Essa previdência em relação ao futuro - que talvez só no presente possa ser entendida dessa forma, na medida em que (para ela) o desemprego de longa duração nunca havia sido, até 1996, nem um fato, nem uma ameaça - revela também a consciência de um desamparo: não é possível contar apenas com a aposentadoria para a manutenção do padrão de vida; é preciso ter outras fontes de renda para que um dia seja possível parar de trabalhar.

\section{Esses jovens de hoje...}

Falando das discussões que faz na igreja, Fátima comentou que o grupo do qual faz parte discute bastante alguns problemas sociais que reconhecem como mais graves: desemprego, drogas, violência e prostituição infantil101:

"Discutimos muito o emprego, os jovens, os adolescentes e, discutimos drogas, discutimos a prostituição infantil que hoje em dia - eu vejo mais nas periferias, é o lugar mais atingido - essas meninas que ficam grávidas, sem expectativa de vida, não trabalha, não estuda, ficam grávidas... Eu acredito que no Brasil tem muita gente, você não pode, essas crianças, eu questiono muito... Essas meninas que ficam aí, todos anos ficam grávidas, todos os anos crianças, você só vê crianças, crianças, crianças. Não, gente, eu acho que... a gente discute muito esses assuntos, muito: drogas e prostituição infantil. Eu bato muito nessa tecla porque eu acho que não pode ser assim".

Embora Fátima enumere alguns temas que ocupam o centro dos debates da comunidade, a preocupação maior parece ser com os jovens e com o que ela chamou de "prostituição infantil"102. Após o término da entrevista, Fátima ficou me perguntando sobre os jovens que eu havia entrevistado, como eles encaravam o trabalho, quais eram as preocupações que eles tinham. Nessa conversa, ficou claro

\footnotetext{
${ }^{101}$ Não à toa que essa discussão, fortemente marcada pela moralidade, ocorre no espaço da Igreja. Como já apontei acima, em diversos momentos de sua narrativa Fátima revela sua formação cristã tanto na forma de conceber as vagas no mercado de trabalho como "bens" a serem repartidos com justiça, quanto nessa forma de pensar a pobreza cindida entre aqueles pobres que merecem ajuda "salvação" - e aqueles que não merecem. Para uma discussão sobre a distinção entre merecedores e não-merecedores, ligada à religião cristã, ver Howe, 1990.

102 No entanto, pelo tom de sua fala e pelos exemplos que ofereceu, parece se tratar mais do problema da gravidez na adolescência.
} 
que a preocupação de Fátima com a juventude se refere a um grupo muito específico de jovens - aqueles que não se interessam pelos estudos ou pelo trabalho e que, portanto, estariam em maior risco de fazer uso de drogas e resvalar para o mundo do crime $^{103}$. Ela reconhece que há jovens responsáveis, esforçados e preocupados com o futuro, mas, em geral, acredita que eles não têm "a cabeça no lugar".

"As escolas também, eles falam muito sobre drogas, só que não adianta. Vem pessoas dar palestras sobre drogas, falam sobre drogas, drogas e Aids, passam filmes só se vê neguinho queimando droga. Falam, entra por um ouvido e saem pelo outro. Prostituição infantil também, é de chorar você ver uma criança com 15, 14 anos grávida. Pelo menos eu tenho muita pena porque é uma infância totalmente destruída, é uma pessoa que não tem expectativa de vida, uma menina com 14 anos, grávida. Ganha o bebê e depois não tem como sobreviver porque não tem emprego, quer que o governo, o Fome Zero resolva o problema desse pessoal. Não é assim, não existe Fome Zero que vá resolver o problema, as pessoas têm de se conscientizar que uma menina de 14 anos não pode ficar grávida, ela tem de estudar, vai fazer... Tem tantos cursos, a ACM dá cursos de informática, a prefeitura, tem tanto cursos aqui (no Centro Solidariedade)104. Não pode pagar uma escola? Vai procurar eu conheço pessoas que saem à pé lá do Turíbio e vinham fazer curso de informática aqui à pé, quando a pessoa tem força de vontade. Vai fazer curso, vai estudar, vai tentar uma vida melhor, arrumar um emprego... Grávida? Filhos? Gente, pelo amor de Deus. Outras param de estudar por que ficaram grávidas, e não voltam a estudar mais...".

Importa notar que, a despeito de reconhecer que não existem empregos para todos, Fátima aponta como saída os estudos, a realização de cursos, enfim, a construção da empregabilidade. E as dificuldades criadas pela distância em relação aos cursos, à escola (e aqui fica claro que ela está pensando principalmente na população que reside na periferia), não deve servir como desculpa, pois há que se realizar sacrifícios: percorrer longas distâncias a pé, na busca de uma vida melhor.

\footnotetext{
${ }^{103}$ Esse modo de compreender (e temer) a juventude se relaciona à maneira de construir o problema da "inserção" dos jovens - num momento de transformação dos referenciais que estruturavam a transição para a vida adulta, a "inserção" se repõe enquanto uma questão social e a idéia de inserção está intimamente relacionada a seu contraponto, a "exclusão", que é figurada, assim, como um risco constante. Ver Dubar, s/d.

104 Quando fiz a segunda entrevista, esses cursos já não eram mais oferecidos: a exemplo do que aconteceu com outras centrais sindicais, devido à redução dos recursos do Fundo de Amparo ao Trabalhador - FAT repassados, muitos cursos deixaram de ser oferecidos.
} 
Ainda, a menção ao Programa Fome Zero confirma o universo que Fátima tem em mente ao problematizar a gravidez precoce: trata-se do universo da pobreza e dos pobres - "esse pessoal".

Há na tematização da juventude, por parte de quem começou a trabalhar em outra época, importantes elementos que nos ajudam a compreender melhor as tensões existentes entre aquilo que, nesta pesquisa, chamou-se de cultura do emprego e cultura do trabalho.

Os jovens e o modo pelo qual estabelecem sua relação com o mundo do trabalho tornam mais visíveis alguns dos deslocamentos ocorridos neste mundo. Fátima diz perceber que os jovens de hoje não têm "a coragem para trabalhar":

"Tem muitos jovens que não tem coragem de levantar de manhã e trabalhar, assim, trabalhar e ter responsabilidade. Porque tem pessoas que querem trabalhar mas não querem ter a responsabilidade: querem trabalhar o dia que quiserem. Chega na segunda-feira e não vai trabalhar porque no domingo passeou, ficou cansado não foi trabalhar, vai no postinho, sei lá, pega o atestado e leva na empresa. Tal dia resolve não ir trabalhar, está com uma dor de cabeça, sei lá, não vai trabalhar e falta no emprego por coisas banais. É assim. A pessoa, a partir do dia em que entra para trabalhar numa empresa, tem que usar o uniforme da empresa, lutar pela aquela empresa, trabalhar honestamente. Não faltar, não chegar atrasado e ter responsabilidades. E o que eu vejo dos jovens de hoje em dia, a maioria deles não têm coragem de trabalhar. O negócio deles é ir dormir à uma da manhã e dormir até meio-dia. Ficar no computador, aqueles que têm, na internet, mas assumir mesmo a responsabilidade de uma empresa, tsc, tsc, tsc. A maioria deles não têm coragem".

O que ela chama de "coragem para trabalhar", portanto, refere-se à disponibilidade para a assunção de responsabilidades com uma empresa. Não causa surpresa que esta seja a referência, pois se trata do tipo de trabalho que Fátima sempre conheceu de perto: ela sempre trabalhou em indústria, seu marido também; seu irmão e seu cunhado são empregados no mesmo banco desde que chegaram a São Paulo. A disponibilidade que têm (ou tiveram) para o trabalho - o compromisso, a responsabilidade, os cuidados - está ligada ao tipo de relação que estabeleciam com ele: trata-se de construir uma carreira, de aumentar a qualificação, de ocupar postos melhores de trabalho, preferencialmente, no mesmo local. 
Por outro lado, quando Fátima traça o perfil dos seus colegas de escola e pondera a involuntariedade do desemprego, fica claro que o jovem, no seu entendimento, ocupa outro lugar no mundo do trabalho, pois o desemprego de quem sempre trabalhou é diferente do desemprego de quem procura o primeiro emprego:

"Olha, a classe quase todas, todas com o mesmo problema, a maioria... Exceção eram os jovens, o jovem às vezes é desempregado por que nunca trabalhou, e quando a pessoa nunca trabalhou, ela não sabe que é trabalhar, ela não sente muito. Agora, a pessoa que trabalhou a vida inteira e de repente perdeu o emprego, voltou para a sala de aula, é difícil...Então, a maioria das pessoas tinha esse problema. (Eram) mais mulheres, a maioria das pessoas tinha esse problema: já trabalharam, perderam emprego, aí depois para voltar no segundo emprego eles exigiam o segundo grau. E nem só pessoas de idade, as mais novas também; tinha pessoas de idade também mas 90\% do pessoal que estudava, não trabalhava não por opção própria, mas porque não conseguia emprego".

Ora, como ficará mais claro no Capítulo 5, para além da multiplicação das formas de trabalho (trabalho em casa, trabalho por contrato, trabalho por projeto, trabalho temporário...) e da desestruturação de setores do mercado de trabalho, a perspectiva de conseguir um emprego, regular e duradouro, é ela mesma posta em xeque pela realidade vivida pelos jovens - melhor dizendo, pelo universo dos jovens pesquisados. Como mostrei no Capítulo 2, a imensa maioria deles tem segundo grau completo, o que não significa que consigam emprego com mais facilidade. É também a maioria deles que sonha em começar logo a trabalhar para fazer uma faculdade numa estratégia claramente enunciada de ter acesso a trabalhos menos precários, melhor remunerados e mais estáveis.

Mas não se trata, neste momento, de levantar argumentos em defesa desses jovens, acusados de falta de coragem para o trabalho. O que importa realmente aqui é apontar a tensão que aparece na fala de Fátima, a partir de sua observação das maneiras com que os jovens se pensam em relação ao trabalho. A ela, parece inadmissível que se deseje burlar a ordem do trabalho, escapar dele já que o trabalho é o único meio justo e honesto de fazer a vida. Sua crítica aos jovens está apoiada sobre os referenciais de sua própria experiência, uma experiência de trabalho que 
cada vez existe menos mas que persiste no imaginário de toda uma geração de trabalhadores ainda em idade de trabalhar.

Portanto, esse modo de compreender os jovens é também um modo de fazer a crítica às novidades do mundo do trabalho que informam o seu comportamento. $\mathrm{O}$ que provoca a tensão presente na fala de Fátima é o esforço por interpretar as novas maneiras de viver e trabalhar (uma vez que, para ela, ambas as atividades não se pensam separadamente) a partir de referências que perderam seus apoios materiais, persistindo no entanto como lembrança e informando o olhar que dirige à nossa sociedade, hoje.

É neste sentido que essa maneira de compreender os jovens nos ajuda a iluminar aspectos da distinção entre cultura do emprego e cultura do trabalho. As características que Fátima atribui ao tipo de trabalho que o jovem não teria coragem para realizar são características do que ela conhece como emprego: trabalho regular, horário fixo, uso de uniforme, perspectiva de carreira; um compromisso, enfim, orientado pela contrapartida da empresa, de estabilidade e reconhecimento à medida em que se vai ficando "velho de empresa". A cultura do emprego, então, mais do que um imaginário que sustenta desejos e perspectivas de futuro, informa também um modo de compromisso com o trabalho, informa práticas de trabalhadores.

Por outro lado, Fátima identifica algumas ações que seriam esperadas de um jovem que não encontra emprego: nada de drogas ou gravidez, mas um empenho pessoal em superar as dificuldades. Cursos, conclusão do $2^{\circ}$ Grau - mesmo que não haja emprego, como ela reconhece não haver, trata-se da construção do "merecimento", trata-se de procurar, no mesmo movimento, legitimar a ordem social (levando a sério a escola, os estudos, os cursos de informática) e legitimar-se perante aqueles que poderão prestar assistência (pois programas como o Fome Zero, tendo o caráter de assistência, devem atender a população que realmente necessita e não aquela que age sem se preocupar com o futuro, sem ter perspectivas de melhora por esforço próprio).

Quando me refiro à cultura do trabalho é a esse imaginário e a essas práticas de legitimação social que me refiro - práticas que adjetivam a condição de pobreza, tornando-a merecedora dos cuidados da sociedade pela virtuosidade de seu modo de 
viver, assim: pobre, mas esforçado; pobre, mas estudioso; pobre, mas com a cabeça no lugar ${ }^{105}$.

\section{Desemprego como doença - entendendo as causas e reconhecendo os} sintomas

No início da segunda entrevista, Fátima preocupou-se em fazer uma análise da situação do desemprego no Brasil. A esse propósito, é importante notar que, ao contrário da primeira entrevista, na qual relatou sua história de modo muito vivo e pessoal, na segunda entrevista Fátima parece ter se distanciado da experiência do desemprego, procurando analisar o problema não do ponto de vista de quem o vive, mas da perspectiva de quem observa ${ }^{106}$.

"Mas eu conheço famílias em que estão todos na casa desempregados. É muito difícil, na minha cabeça, a pior doença do mundo é o desemprego, na minha cabeça...É triste, eu oro, às vezes eu rezo tanto, demais pelo desemprego, famílias desempregadas... Eu me preocupo demais com uma família desempregada".

Há aspectos importantes aqui: o primeiro deles é a inscrição do desemprego no universo das doenças - o que aponta para o caráter de vítima assumido pelo desempregado; o desemprego aparece nessa representação como fatalidade a qual os trabalhadores estão sujeitos. Outro aspecto é a maneira de localizar o que é atingido pelo desemprego, além do próprio trabalhador desempregado: a família toda sofre, seja porque o desemprego atinge mais do que um membro da família, ameaçando a sobrevivência, seja porque a idéia mesma de família fica posta em xeque - com a indefinição de papéis antes bem estabelecidos e com o desgaste provocado pela constante dificuldade.

Fátima descreve os "sintomas da doença" do desemprego:

\footnotetext{
105 Sobre as figurações da pobreza, ver Telles, 2001, especialmente o capítulo 3, "Trabalho e formas de vida".

106 É possível que essa mudança possa ser creditada à situação: da primeira vez, entrevistei outras pessoas além dela; da segunda vez, entrei em contato por telefone, ela foi a única entrevistada e, talvez, ela tenha chegado à conclusão de que a importância de seu relato residia não em sua experiência, mas na racionalidade e veracidade de suas análises. Outra hipótese é que o prolongamento do período de desemprego, e a desistência da procura, a tenham afastado mesmo da identidade com a situação: não mais desempregada, mas "parada".
} 
"Esses sintomas, eu já, conversando com algumas pessoas, eu conheci uma senhora, casada, nova, uma moça, casada, mas ela tinha o que? Seus vinte e poucos anos. Ela ficava desempregada e ela tinha todos os sintomas: ela tinha tontura, dor de cabeça, mal-estar. Verdade. (...) ela ficava doente, doente, doente mas o doente do espírito, doente psicologicamente. Quando ela começava a trabalhar, ela sarava. Tem pessoas que ficam doentes mesmo, acham que o mundo desabou na cabeça, acho que para ela...Tem pessoas que não querem viver: têm vontade de furar um buraco, entrar dentro para não ficar nem um fio de cabelo do lado de fora. Tem pessoas que suicidam, não é? Se a pessoa não pedir a misericórdia de Deus, se não for uma pessoa de cabeça feita, tem pessoas que se suicidam".

Reforçando a representação do desemprego como uma situação desestruturadora, Fátima relata alguns sintomas físicos para em seguida revelar que eles têm origem naquilo que é atingido pelo desemprego: o espírito, a estrutura psicológica. Como são estes aspectos pessoais que são atingidos, é a eles que se deve prestar atenção a fim de manter a “cabeça forte" e enfrentar a situação:

"Cabeça forte é aquela pessoa que não pensa só o negativo. porque tem pessoas que só pensam o negativo: fica desempregado e acha que o mundo acabou, desabou em cima, acabou. Então, a pessoa de cabeça fraca, aí ela pensa somente negativo, e aí é onde vem a depressão, onde a pessoa não consegue dormir, aí vai o médico e o que o médico fala? Calmante, antidepressivo para dormir. A pessoa se torna dependente de muitos remédios para poder dormir. São pessoas de cabeça fraca. E as pessoas de cabeça forte são aquelas que perde um emprego, ela não desanima, ela levanta a cabeça e ela toca o barco para frente, seja o que for, para fazer outra coisa..(...) mesmo que seja mudar de profissão, sei lá. Não pode é ficar parado".

Para combater a doença e manter a cabeça forte, portanto, é preciso um comportamento diligente, é preciso não parar - o que mais uma vez explica as expressões utilizadas pelas pessoas em desemprego aberto para descreverem seu cotidiano: "correria", " andar o dia inteiro", "se virar".

Esse diagnóstico da situação de desemprego é o que orienta as providências tomadas pela comunidade da Igreja quando alguém se desemprega:

"A primeira coisa é uma palavra de conforto para que a pessoa não desanime, e depois verificar se falta o leite para as crianças, verificar os problemas da família e a gente tentar ajudar. Não uma só, uma pessoa só não consegue, igual eu não consigo ajudar. Mas a gente se 
reúne entre os moradores, entre a comunidade da igreja e vamos formar uma cesta básica, vamos ver o que a gente pode fazer, vamos ver aonde tem doação de leite, vamos ver o que a gente pode fazer para aquela família e, principalmente quando acontece criança. Aí a gente vai verificar aonde é que tem um emprego, nem que seja de doméstica, para passar roupa, para fazer alguma coisa, arrumar - se tem mocinha - arrumar serviço de babá, alguma coisa assim para que aquela pessoa consiga alguma coisa pelo menos para sobrevivência".

O mais importante é fortalecer a pessoa, orientando-a a encontrar outras estratégias caso o desemprego se prolongue. Cuidar desse aspecto é tão importante que vem primeiro do que a garantia da sobrevivência - o fundamental, no primeiro momento, é assegurar o pertencimento daquele indivíduo a um grupo de referência, pois que ele se encontra numa situação liminar que pode levá-lo ao desejo de exclusão ("se enfiar num buraco" ou suicidar-se, como exemplos extremos).

As orientações se referem tanto às novas estratégias de "viração" quanto à disciplina dos gastos: "o que nós falamos para essas pessoas (da comunidade) que, às vezes, perdem o emprego é para que a pessoa não desanime e procure fazer outra coisa. Porque eu acho assim um pai de familia, perdeu o emprego, ele não pode parar, ele tem que fazem outra coisa, inventa outra coisa que dá certo! Igual tem muitas pessoas que param de trabalhar e, perdem um emprego, aí ela faz coxinha, ela vende produtos de limpeza, faz Comfort, amaciante, coloca plaquinha "Vende-se produtos de limpeza" e coisa e tal. Ela arruma ou tra forma de sobrevivência e hoje em dia você vê muito, aqui não, mas se você andar pelos bairros das periferias o que você vê de placas "Conserta-se roupas", "Troca-se zíper", "Faz salgados, bolos", "Vende produtos de limpeza"; então é uma forma de sobrevivência. A pessoa tem de inventar, vender alguma coisa ou, sei lá... A pessoa tem que bolar alguma coisa para sobrevivência, não pode ficar parado. Foi mandado embora, pegou o dinheiro que recebeu da indenização, estoura tudo. Não é assim. Foi mandado embora? Pegou a indenização? Guarda, gasta o suficiente para sobreviver...".

Essa fala de Fátima é bastante reveladora da dinâmica das famílias frente ao desemprego. Primeiro porque, mais uma vez, nos ajuda a localizar o mundo do trabalho a partir do qual Fátima está falando: pai de família, recebimento de indenização no encerramento do contrato, emprego... Esse é o mundo do emprego formal, contraposto (como nota Fátima) às estratégias de sobrevivência que se tornam necessárias a partir da perda desse emprego. Daí para frente, na ausência de 
um novo emprego, é importante se virar, utilizando as estratégias das classes mais baixas - localizadas nos bairros de periferia que ela toma como exemplo.

O que há de mais importante nessa fala de Fátima é a enunciação da transformação dos papéis familiares que advém da situação de desemprego pois, embora diga que é o pai de família que não pode ficar parado, as atividades que enumera são ditas no feminino: ela vende produtos de limpeza, cozinha bolos ou coxinhas, costura... Ela é quem toma para si a responsabilidade de inventar novas maneiras de garantir a sobrevivência - mas se trata de uma invenção que nada tem de novidade, a não ser pelo fato de que serão trabalhos desempenhados com outros objetivos, (o comércio e a garantia da sobrevivência), e cujos produtos deixarão de permanecer no interior da unidade familiar.

Desloca-se o papel do pai de família, desloca-se o papel da mulher: é essa realidade que Fátima reconhece quando se preocupa com as famílias desempregadas. A maneira como constrói a questão nos revela um importante deslocamento, pois também dá notícia da transformação do modo de trabalhar de sua classe média simples. Afinal, o alvo de sua preocupação é o pai de família que tinha um emprego e que deixa de ter.

Quando pensa no desemprego, é desse desemprego que está falando. Reforça essa interpretação a preocupação que demonstra em relação ao cunhado: “Eu me preocupo com o meu cunhado, meu Deus do céu, meu cunhado trabalha há trinta anos no Bradesco, inclusive ele não quer se aposentar, se o Bradesco dispensar aí ele recorre à aposentadoria porque a aposentadoria hoje você sabe como é que é. E ele tem as filhas: a Liliana se forma agora, recebe a colação de grau dia 4 e a Kéti, ainda paga a faculdade da Kéti, sim, porque as duas mais velhas fizeram faculdade na USP e a Kéti, eles pagam $R \$ 600,00$ de faculdade, na FIEO, porque a Kéti não trabalha e também não consegue emprego". A percepção do risco se integra ao reconhecimento das transformações que têm lugar no mundo do trabalho - tendo sempre trabalhado no mesmo lugar, já com a idade avançada, a única resposta que o cunhado poderá ter frente à dispensa será recorrer à aposentadoria, já que as chances de se empregar novamente são reduzidas.

Fátima atribui o desemprego a duas razões principais: 1) às políticas econômicas estabelecidas durante os anos de governo Fernando Henrique Cardoso e 2) à 
tecnologia. Dentre as políticas econômicas, Fátima sublinha sobretudo a abertura econômica, como mencionado anteriormente. Para ela, essa abertura acabou provocando efeitos desastrosos sobre as indústrias e empresas brasileiras, causando falências e conseqüentes demissões:

"Então, eu acho que um pouco, o desemprego, foi a tecnologia, e outro pouco também por causa do governo, do presidente (Fernando Henrique Cardoso). Porque você se recorda quando a Mafersa queria produzir as peças de trem, ele deixou de dar as peças da Mafersa e importou da Alemanha? (...)é, (ele decidiu que) vamos importar de lá porque lá o produto mais barato. Conclusão: ferrou aqui, ferrou aqui...".

Reconhecendo que as medidas econômicas tomadas durante oito anos não podem ser revertidas sem dificuldade, Fátima se diz confiante no novo governo "Sempre fui do Partido dos Trabalhadores - eu torço para que dê certo", mas não acredita que seja possível realizar mudanças rapidamente ou gerar empregos suficientes para resolver o problema do desemprego. É essa constatação da enormidade do problema que a faz pensar que não há possibilidades de mudança, a única saída possível repousando sobre a misericórdia de Deus:

"Aqui no Brasil, o desemprego é uma história muito preocupante, só Deus é quem pode ter misericórdia. Quem tem o seu emprego, dobre o joelho no chão e agradeça a Deus, e quem não tem... É muito difícil. Hoje, o que eu vejo, muitos jovens que terminam o segundo grau, ficam perambulando à procura de emprego e não conseguem. Por quê? Todas as empresas, elas pedem experiência e eles, no início não tem como ter experiência. Quando os pais têm um poder aquisitivo, que podem pagar uma faculdade, tudo bem, e os demais... é muito difícil hoje em dia, tanto as crianças da periferia quanto até da classe média, eu vejo muitos desempregados e o pessoal se apega muito às mudanças do governo; mas não, é difícil, não é a mudança do governo, poucos meses que ele está lá dentro do poder, menos de um ano, que ele vai conseguir mudar alguma coisa. A expectativa é boa, mas o desemprego é muito grande".

Quanto à relação entre tecnologia e desemprego, aparece claramente a idéia da substituição progressiva dos trabalhadores:

"Eu acho também, que a principal causa do desemprego é a tecnologia avançada, porque é há alguns anos atrás não existia o computador numa sala de administração, era tudo feito no manual, máquina de escrever, coisa e tal. Hoje não, hoje tem um computador, o computador tira mão-de-obra de que? De 20, 30 pessoas. Ou mais. Essas máquinas que vêm dos Estados 
Unidos, de alta tecnologia, tira a mão de 50 operários; então, eu acredito que a maior causa do desemprego, um pouco é isso daí. Não é culpa do governo, não é culpa de... Sim, é má administração dos governos anteriores, mas acredito que também é a tecnologia. Hoje dia é muito difícil a pessoa conseguir um emprego e eu acredito que seja por causa disso aí".

Permeando tal análise, o tema da terceirização surge, como mais um fator, causador não apenas do desemprego mas também da mudança no padrão das relações de trabalho. Tais preocupações emergem de sua experiência de trabalho na gráfica - um setor que realmente sofreu grandes transformações devido à tecnologia:

“Veja bem que é $A B N$ (a gráfica para a qual prestava serviço de vez em quando) era do Bradesco, e aí o que o Bradesco fez? Ele achou que era mais vantagem de vender a $A B N$, a gráfica dele para a $A B N$ e comprar os talões de cheque - a ABN fabrica os talões de cheque e vende para o Bradesco a $R \$ 1$, o talão de cheque. E nós, eu sei porque pego de vez em quando talão de cheque, quando você pede talão de cheque é $R \$ 6$, não é isso? Era, porque um talão de cheque para mim dá para dois anos. Então, é $R \$ 6$. O que o Bradesco fez? Ele preferiu se desfazer da gráfica e fazer prestação de serviços com a $A B N$. Então eu vi na ABN, aquelas máquinas enormes que fazem talão de cheques, trabalha para o Bradesco, para a Caixa Econômica, para o banco Itaú, aquelas máquinas que intercalam é um monte de mãozinhas, os envelopes saem lá, prontinhos! E aí eu comecei a observar: uma máquina dessa tira mão-deobra de 50 funcionários".

Terceirização, tecnologia, dificuldades causadas pela abertura econômica: as explicações oferecidas por Fátima mostram que, no plano das grandes explicações gerais, ela sabe exatamente o que está acontecendo. Ela sabe o que causa o desemprego, pelo menos no que se refere àquele que ocorre nos lugares do mercado de trabalho que ela e sua família ocupavam.

Mas esse conhecimento objetivo das mudanças e crises sociais não diminui as tensões e as incompreensões que têm lugar em sua vida cotidiana, em seu modo de compreender o mundo. Ao contrário, esse conhecimento parece aumentar a tensão pois que às dificuldades experimentadas durante o período de desemprego só acorrem um conhecimento do presente que esbarra na enormidade dos problemas e a fé - que serve de suporte à esperança.

É assim que a compreensão da situação - em toda a sua complexidade - ao invés de conduzir à ação, no sentido arendtiano, conduz ao reconhecimento de que 
nenhuma ação é possível, o que tem sua razão de ser pois as decisões que precisariam ser tomadas para iniciar a solução dos problemas não podem ser tomadas nem mesmo pelo Presidente do país. A possibilidade de intervir nos processos é mínima independente do ator que se tome como referência. Se fosse objetivo do trabalho aprofundar as análises macro-estruturais, poder-se-ia pensar nos deslocamentos do papel do Estado Nacional que a fala de Fátima intui e revela na afirmação que só a intervenção divina teria alguma chance de fazer as coisas melhores.

Mas como não é disso que se trata, fixemos apenas esse aspecto: quando, nesse trabalho, aponto a dificuldade de compreensão do presente que identifico nas diversas entrevistas colhidas, quando aponto para a privação que revelam, não estou dizendo que as pessoas sejam incapazes de compreender os processos globais, macroeconômicos, macro-estruturais, como se queria nomeá-los. Elas os compreendem bastante bem. A dificuldade de compreensão que quero apontar se revela na dificuldade de identificação de novos espaços de invenção; é a dificuldade de entendimento de quem são os novos atores, onde se localizam, como podem intervir, a onde podem nos conduzir.

\section{II - Sem tempo para nada - Maria Suely}

Suely tem 38 anos. É separada e mãe de dois filhos - o mais velho com 17 e o mais novo com 4 anos. Branca, não muito alta, cabelos bem curtos, dona de uns olhos grandes e bonitos e de uma voz feminina e forte, se fosse necessário descrever Suely em apenas uma palavra, a mais adequada seria vivacidade: Suely não pára e, a despeito de todas as dificuldades que enfrenta, não é difícil vê-la sorrir.

Outra característica marcante se refere à sua honestidade. Ela não tem pudores de dizer o que está pensando, perguntar o que não entendeu ou deixar clara a sua posição. Na primeira entrevista, ao final, quando expliquei que continuaria fazendo a pesquisa e talvez precisasse procurá-la novamente, ela imediatamente me perguntou "Mas é você quem vai até mim, né, isso não vai implicar em nenhum custo? Porque eu não tenho como ficar gastando dinheiro...". 
A primeira entrevista que fiz com ela, em outubro de 2002, foi bastante dolorosa. Eu mal começara a pesquisa de campo e, portanto, meu repertório de histórias e casos ainda estava por se constituir, o que me tornava mais sensível para algumas falas e discursos justamente por ainda não haver construído um quadro mais geral no qual pudesse inseri-los. Durante a entrevista, Suely, comentando sobre as razões às quais creditava a dificuldade em encontrar um novo trabalho, começou a falar da idade, da escolaridade e incluiu no mesmo rol o problema da obesidade todos fatores que ela atribuía a si mesma.

Continuamos a entrevista e, ao final, quando nos despedíamos, disse a ela que havia decidido pesquisar o desemprego para entender o que estava acontecendo no mundo do trabalho e também para mostrar que as razões que levam ao desalento provavelmente não se deviam apenas a problemas e dificuldades individuais ou pessoais; disse ainda que achava que algo estava muito errado quando uma mulher jovem e bonita acreditava que as razões pelas quais não encontrava um novo emprego tinham a ver com não ser mais tão jovem ou estar gorda. Ambas ficamos um pouco comovidas; em seguida, ela sorriu e disse "Mas o pior é que é verdade". A consciência dos limites e do modo de funcionamento da sociedade transpassa mesmo a mais tênue tentativa de problematizar a situação e a resposta de Suely teve tanto ou mais impacto sobre mim do que suas falas durante a entrevista pois me apresentaram, com muita força, as barreiras percebidas por ela e a impossibilidade de transpô-las, principalmente se individualmente.

A trajetória de Suely permite pensar sobre alguns aspectos relacionados a uma trajetória mais "tipicamente feminina". Ao contrário da narrativa de Fátima, cuja experiência operária traz à frente da cena a centralidade do trabalho, Suely está constantemente conciliando e equilibrando o papel de mulher, mãe e trabalhadora. Em sua narrativa, elementos dessas diversas esferas se entrecruzam, se confundem, e explicitam que, para ela, o trabalho é importante para a ocupação do tempo, mas é principalmente um meio para a realização daquilo que sonha para si e para seus filhos. Talvez por isso, Suely transita com mais facilidade entre empregos e trabalhos ("bicos”), pois o que aparece como mais importante é a remuneração recebida e o que ela permite fazer. A partir da trajetória de Suely, revelam-se aspectos mais 
relacionados a uma cultura do trabalho, mas que aparece aqui marcado pelo signo da condição feminina: ainda que os trabalhos desempenhados por Suely se aproximem das atividades de "viração", o sentido de que ela os reveste se distancia bastante do esforço de sobrevivência material e identitária que aparece tão fortemente na narrativa de José. Qualquer que seja o trabalho que desempenhe, Suely está mais preocupada com os frutos do trabalho, com aquilo que ele poderá produzir em termos de segurança e garantias para si e para os filhos, do que com a teatralização da diligência e da honestidade. Em sua vida, o trabalho é meio e, por isso, dentre as histórias apresentadas nesta dissertação, Suely é quem demonstra mais facilidade para transitar por outros papéis.

Outro aspecto que é possível discernir na trajetória de Suely se refere às diferentes possibilidades de encontrar alternativas, condicionadas pela existência ou não daquilo que João Bosco Feitosa dos Santos chamou de "estatuto de substituição", ou seja, os suportes - materiais e sociais - de que dispõem as pessoas desempregadas, demarcando a duração dessa condição, num contexto de falta de um sistema de seguridade eficiente e extensivo (Santos, 2000).

Finalmente, a trajetória de Suely dá notícia de um desalento que, embora relacionado ao cansaço das buscas malogradas, não implica em paralisia. Enquanto não procurava, Suely fez cursos, terminou o segundo grau e, mais tarde, fez a transição para o desemprego oculto pelo trabalho precário. Ao todo, contando o período entre a perda do emprego no posto de gasolina e a consecução do novo emprego, em um supermercado, Suely permaneceu três anos desempregada - "Fiquei três anos desempregada, certinho".

Na ocasião da segunda entrevista, em fevereiro de 2004, Suely havia voltado a trabalhar há quase dois meses, num pequeno supermercado instalado no bairro onde mora $^{107}$.

\footnotetext{
${ }^{107}$ Embora esse aspecto vá merecer uma análise mais cuidadosa ao longo da exposição da trajetória de Suely, é interessante ressaltar que ela mesma nota a precariedade desse emprego conseguido no bairro - a despeito de ser registrado: a empresa contratou moradores do bairro para não pagar valetransporte; o salário recebido por ela é bastante inferior àquela que costumava receber quando trabalhava em postos ou em comércios em São Paulo; ela trabalha seis horas e almoça em casa todos os dias, prescindindo de tíquetes alimentação. Por outro lado, ela vê também ganhos no trabalho conquistado: para além da alegria de ter voltado a trabalhar, o trabalho perto de casa permite a ela não
} 


\section{Trajetória de Trabalho}

A família de Suely, originária do interior de Minas Gerais, mudou-se para Carapicuíba quando ela tinha seis anos. Hoje em dia, sua mãe mudou-se para o interior de São Paulo, mas dentre os seus doze irmãos, à exceção de uma irmã que se mudou para Natal e de outra que mora no centro de São Paulo, todos os outros moram na região de Barueri (onde Suely mora), Osasco ou Carapicuíba.

Na primeira entrevista, perguntei o que Suely, quando jovem, sonhava fazer quando se tornasse adulta e ela me respondeu: "eu não tinha assim muitos sonhos não, sabe, eu era meio largada mesmo. Eu comecei a pensar em ter alguma coisa mesmo depois que eu separei, em fazer alguma coisa". Essa fala ajuda a começar a compreender o lugar do trabalho na vida de Suely.

Suely começou a trabalhar aos dezesseis anos, numa tecelagem. Porém, o salário era muito baixo e ela acabou deixando este trabalho para ir trabalhar com a irmã, numa indústria metalúrgica que produzia aparelhos de som. Perguntei se ela lembrava quanto tempo tinha ficado procurando emprego, entre estes dois, e ela respondeu que não sabia pois "naquela época era fácil, (...). Para você ver, (saía e) já encaminhava para um, inclusive na tecelã (sic) eu trabalhei dois meses, acho que dois meses no máximo e aí a minha irmã já me tirou e já colocou na firma dela, onde ela trabalhava. E naquele tempo era muito fácil, tipo, lá eu ganhava mais ou menos meio salário mínimo e no outro, que minha irmã me arrumou, era bem mais, né? Então era muito fácil, eu lembro que eu não demorei". A exemplo de pessoas que iniciaram suas trajetórias de trabalho até o início dos anos 80, Suely distingue o momento em que entrou no mercado de trabalho do momento atual, apontando que naquela época era mais fácil.

Nessa metalúrgica, ela ficou mais ou menos dois anos. Depois que saiu de lá - e mais uma vez ela não é capaz de precisar quanto tempo permaneceu desempregada - entrou numa gráfica, fazendo etiquetas. Mas não ficou muito tempo porque a fábrica logo faliu: "acho que lá eu fiquei pouquinho tempo porque meu irmão trabalhava láe

precisar pegar trânsito, almoçar com os filhos e estar em casa à tempo de mandar o mais novo para a escola. 
me colocou, só que a firma já estava falindo, era uma firma assim que eu não sei, pegava o pessoal e o pessoal estava falindo já, eles não registravam".

Tomando como referência essas primeiras experiências de trabalho, é possível notar que a inserção esteve ligada aos contatos pessoais: na primeira indústria, ela foi levada pela irmã; na gráfica, entrou levada pelo irmão. Ainda que Suely diferencie as maneiras de procurar emprego "daquela época" e de hoje, apontando também para o surgimento das agências e de novas necessidades, tais como a entrega de currículo, ela não oferece exemplo de procura em portas de fábrica e as redes pessoais aparecem como a principal estratégia.

Saindo da gráfica, mudou de área de atuação: "E se eu não me engano de lá eu entrei numa outra firma, em Alphaville, que era...Não, espera aí. Aí eu entrei no Café Seleto, trabalhava no Café Seleto como demonstradora, trabalhava lá no shopping Eldorado, também fiquei quase dois anos. Mas é por aí, se eu não estou colocando uma na frente da outra, é mais ou menos isso".

Parece difícil precisar a trajetória. À diferença da narrativa de Fátima, em que os momentos de mudança têm data marcada, Suely confunde a ordem dos trabalhos realizados, transita entre empregos registrados e não registrados...Sua trajetória é mais descontínua e, nesse sentido, mais parecida com a de José (Capítulo 3). Mas o sentido da descontinuidade é outro, como ela mesma avalia, na fala já mencionada, deixando claro que o trabalho só passou a ter uma outra importância em sua vida após a separação, quando ela também assumiu outras responsabilidades para com a sobrevivência da casa e a conquista de suas próprias coisas. A discussão sobre o caráter da trajetória de Suely será retomada mais à frente.

Após sair do trabalho de demonstradora, Suely voltou à atividade industrial: "depois eu fui trabalhar numa outra firma também, aí já era de caixas acústicas, também era uma metalúrgica lá em Alphaville; aí, daí eu fiquei uns dois anos, aí nesse meio tempo comecei a namorar, fiquei grávida, saí do emprego e quando meu filho tinha um ano e três meses eu comecei a trabalhar de novo no comércio".

Suely, na primeira entrevista, expressou seu desejo de retornar ao setor industrial de metalúrgica. A justificativa para esse desejo está na estrutura do emprego e da remuneração que ela reconhece no setor: "olha, é porque assim, na 
metalúrgica você tem como fazer hora extra, tem como você subir na empresa e no comércio geralmente não, é muito difícil e você ganha pouco no comércio. O salário do comerciante e o salário do pessoal de firma, é diferente. Você trabalha mais como comerciante, muito mais, você trabalha fisicamente e com a mente também você trabalha, cansa muito e você ganha menos. Isso aí não sou eu que estou falando, são entrevistas, são estudos mesmo que mostram eé a realidade. Trabalha mais e ganha menos".

A dificuldade de retornar ao setor de origem, após a interrupção motivada pela gravidez e os cuidados com o filho, não é exclusiva de Suely. Hirata e Humphrey, ao estudarem as trajetórias de operários e de operárias e as possibilidades de permanência ou retorno ao setor industrial de origem, após a crise que atingiu o país entre 1981 e 1983, mostraram que as mulheres encontravam mais dificuldades para retornar ao setor industrial após terem sido demitidas e que as condições de empregabilidade estavam diretamente ligadas ao estado civil e a existência ou não de filhos - este último fator se sobrepondo ao estado civil - (cf. Hirata e Humphrey, 1989a).

Depois da primeira gravidez, então, Suely voltou a trabalhar no comércio: "Aí seria em loja, não é? Aí, loja de roupa. Aí eu trabalhei nessa loja de roupas... não, aí eu passei a trabalhar no escritório das lojas Marisa, aí trabalhei no escritório das lojas Marisa também mais ou menos de dois a três anos, aí depois eu passei (...) para a loja de roupas".

$\mathrm{O}$ retorno ao trabalho aconteceu a despeito da implicância do marido, que não queria que ela trabalhasse ${ }^{108}$ : "ele não queria que eu trabalhasse de jeito nenhum. (...) mesmo assim eu voltei a trabalhar porque tudo que você quer você não pode comprar porque... "Ah, eu quero dinheiro", "Para que?" e aí, além de você perguntar, não tem. Além de perguntar o que quer, não tem, então eu sempre trabalhei é muito bom a gente estar trabalhando e saber o quanto custa cada coisa que você compra, né?". O trabalho aparece, assim, como a maneira de manter uma certa independência em relação ao marido, superando tanto as limitações impostas pela falta de dinheiro quanto aquelas impostas pela situação de dona-de-casa.

108 O ex-marido de Suely é Policial Militar e, à época do casamento, já havia ingressado na carreira, não tendo nunca experimentado a situação de desemprego durante o casamento ou após a separação. 
Ao sair da loja, Suely ficou cerca de um ano desempregada. Sem conseguir um novo emprego, optou por montar seu próprio negócio: “aí eu montei um comércio para mim, era uma bombonière, aí o que aconteceu? Eu fiquei três meses com essa bombonière, eu cuidando, né? E fazia um bico no posto de gasolina, de combustíveis e, mais ou menos quando eu estava com um mês, um mês para dois, aí eles queriam me registrar e eu falei, "ah, tudo bem", aí eu paguei duas meninas para ficar na bombonière, e fui para o posto. Mas só que daí, nesse tempo, o que eu juntei quando estava com três meses que eu fiquei lá, as meninas perderam, não sei onde que foi esse dinheiro. Ai eu fechei a bombonière e fiquei no posto, fiquei no posto três anos, depois do posto fui mandada embora, foi quando comecei a procurar emprego".

Suely se recorda com saudade da época em que trabalhava no posto, primeiro como frentista, depois como operadora de caixa. Inclusive, na segunda entrevista, disse que entre um emprego industrial e um emprego no posto do qual fora demitida, preferia este último: "eu queria trabalhar no posto, é no posto que eu queria voltar a trabalhar, inclusive até hoje eu fico assim, fico chateada que eles me mandaram embora do posto. Lá, apesar de ser comércio, é melhor. Para mim era melhor por que eu ganhava mais privilégios; até hoje em dia eu trabalho no mercado, para a gente, nós que somos pobres assim, acostumados com mínimo, o meu mínimo do posto era três, no mínimo duas vezes mais do que onde eu estou".

Há vários aspectos interessantes nessa fala. $\mathrm{O}$ primeiro deles se refere às razões pelas quais valoriza o trabalho no posto, principalmente o "ganho de privilégios". Assim, do mesmo modo que expressou sua preferência em relação a um trabalho industrial, o que informa tal preferência, para além da melhor remuneração, são os benefícios ligados ao emprego: cesta básica, vale-transporte, tíquete refeição, possibilidade de fazer horas extras e de ser paga por elas. Em resumo, ela está a valorizar todos os benefícios que são direitos, mas que - e sua fala deixa claro - de fato, operam como privilégios ${ }^{109}$.

O outro aspecto se refere à sua inscrição social no universo da pobreza: Suely se pensa como pobre e, mais do que isso, aqui nos oferece uma importante figuração da

\footnotetext{
109 Sobre o significado da carteira de trabalho como condição de acesso a uma cidadania pouco extensiva, operando, portanto, uma distinção entre trabalhadores cidadãos e pobres incivis, ver Telles, 2001, especialmente pp.22 e seguintes.
} 
pobreza como a habituação ao mínimo. Ao mesmo tempo, reconhece que o universo da pobreza não é homogêneo: sendo a raiz da necessidade de trabalho constante, o tipo de trabalho encontrado pode matizar a pobreza, distinguindo pessoas que sejam remuneradas por diferentes mínimos. A partilha da condição da mesma necessidade de trabalhar pode, então, turvar-se pelo acesso a diferentes postos de trabalho e diferentes mínimos.

Existe outro motivo, além dos benefícios advindos do emprego, que orienta a vontade de Suely voltar a trabalhar no posto, e ele aparece quando ela enumera tudo aquilo que falta em seu atual emprego: "eu acho que o pessoal de posto agora, a minha função que é caixa, agora a partir de março, (está ganhando) $R \$ 700$, no mínimo e eu estou ganhando 300 e...setenta e cinco bruto. Aí (no novo emprego) você não tem, só tem a cesta básica, não tem vale-transporte, não tem tíquete, não tem um sindicato assim que você pode contar". Mais uma vez, é aos benefícios ligados ao emprego que ela se refere, incluindo aí o direito à representação - Suely participava do sindicato, quando trabalhava no posto, e a ausência de um sindicato nesse novo emprego é percebida como mais um fator de precariedade. Trata-se, sem dúvida, de um trabalho que provê um mínimo diferente daquele oferecido pelo posto ${ }^{110}$.

Quando nos encontramos, da primeira vez, Suely estava desempregada há um ano e nove meses - embora tivesse deixado de procurar em alguns momentos e, em outros, tivesse realizado bicos: "desempregada eu estou há um ano e nove meses. No ano passado procurei, depois eu parei de procurar. Ai, esse ano, eu procuro algum tempo, fico desanimada, por falta de dinheiro também, dá desânimo... comercial porque não tem muita firma, a gente sai para procurar e não encontra, a gente fala "Ah, eu não vou hoje, hoje não é um dia bom para procurar", tipo assim. Faz mais ou menos uns dois meses que eu estou procurando direto, se eu não estou num lugar eu estou no outro, estou distribuindo currículos, eu ando mais de meia hora, uma hora distribuindo currículos pelos postos de gasolina (...) ". É interessante chamar a atenção para a natureza do desânimo experimentado por Suely: ela fala de um desânimo comercial, provocado pelo

\footnotetext{
110 Poderíamos, inclusive pensar de maneira inversa: por não ter representação, por não constituir um grupo de interesses comuns (pensemos, num primeiro momento, apenas nessa dimensão da organização sindical) e por este motivo não alcançarem trazer suas demandas à luz pública é que os trabalhadores do setor de supermercados estão apartados dos "privilégios" ligados ao emprego.
} 
reconhecimento de que não existem muitas firmas, assim como não existem muitas vagas. Ao atribuir o adjetivo "comercial" ao seu desânimo, Suely, até contrariamente ao seu discurso sobre as próprias condições de empregabilidade, dá notícia de uma crise geral, que independe de sua própria ação. Suely chegou a ficar quase seis meses sem procurar - nesse meio tempo retornando à escola para concluir o ensino médio e fazendo cursos (de manicure e de artesanato com meias de seda).

Logo após a primeira entrevista, Suely conseguiu um trabalho, na função de conferente, em Moema: "foi naquela época mesmo, depois que eu falei com você, eu acho que não sei, no máximo foi uma semana depois, aí eu arrumei esse emprego. (...) achei um emprego lá de conferente, lá em São Paulo, lá em Moema. Puxado, longe para dedéu, muito longe. Mas aí falei "mas eu vou". Ganhava quinhentos reais, podia dormir no emprego. Eu trabalhava, tipo, das oito até às onze da noite, ganhava quinhentos reais por mês, mas o que acontece? Eles me davam o vale-transporte e eu não usava porque eu dormia lá; dormia às vezes duas, três noite por semana para poder economizar e eu economizei e com o dinheiro da pensão dos meninos e do aluguel eu fiz meio acabamento aqui e mudei para cá". O trabalho - puxado não era registrado e implicou numa série de mudanças e rearranjos em sua família (aspecto que abordarei na próxima seção); Suely permaneceu lá por seis meses, o tempo de juntar algumas economias e fazer o acabamento da casa.

Depois desse período de trabalho, Suely voltou a ficar desempregada (ainda que, em sua narrativa, ela considere os três anos sem registro em carteira como o período de seu desemprego). Como me relatou, ela já havia perdido as esperanças de conseguir um novo emprego - nesse meio tempo, procurava se virar, fazendo faxinas e trabalhando como manicure, conforme a demanda - quando seu irmão lhe avisou que vira um anúncio de emprego: "Meu irmão falou assim para mim "vai abrir um mercado, em tal lugar assim, assim e assim. Vai lá deixar o currículo". Aí eu nem liguei. Aí com mais ou menos uns quinze dias ele falou para mim "você foi levar o currículo lá?", eu falei assim "aonde?"," lá no mercado", e eu falei "ah, não, mas eu levo hoje", "leva que é até quarta", era na segunda-feira, aí eu levei, no mesmo dia eu levei. Mas não estava com esperança porque eu já tinha entregado tanto currículo, em tanto lugar, não estava mais com esperança. Aí, de repente, me ligam - demorou tanto para sair esse emprego, que perdi a esperança de novo. Fiquei três meses assim, esperando, mas...". 
Suely está bastante contente com o novo trabalho - "é o Dia\% supermercado que é da rede do Carrefour, e estou lá, estou bem para caramba". Perguntei a ela como tinha sido voltar a trabalhar e ela relatou que estava bem mais feliz, mais tranqüila, passara a brigar menos com os filhos e estava se sentindo mais bonita111.

Sua função, no supermercado, é repor o estoque dos produtos hortifrutigranjeiros. Ela contou que, no início, achou muito ruim a seção que lhe foi destinada - "eu falei "nossa, eu vou ficar no hortifruti! As minhas unhas, meu Deus do céu, as minhas unhas vão ficar horríveis" - porém, hoje em dia, acredita que é o melhor lugar, "Porque tudo o que sobra, tudo que está para lixo, eu trago para casa. Eu não faço compra, eu não vou mais na feira; tudo que tem em casa, tudo eu aproveitei, que eu falo"112. O atual trabalho é registrado e fica perto da sua casa (o que lhe permite almoçar em casa, com o filho mais novo).

É interessante notar, no relato de Suely, que ela dá mais atenção ao ramo de atividade ou ao lugar em que trabalhou do que à função que desempenhou. Apenas na primeira entrevista, quando perguntei sobre sua profissão, é que ela relatou algumas das atividades que já tinha realizado: "eu comecei como metalúrgica, primeiro com metalúrgica; depois eu passei à área de comércio, comecei como recepcionista e depois passei a telefonista, depois passei para a confecção e agora, o último foi de combustíveis".

O maior tempo de permanência em um mesmo emprego foi de três anos, no posto. Embora tenha começado sua trajetória num emprego industrial, Suely principalmente após a primeira gravidez - passou a trabalhar no comércio, no atendimento ao público, algo que ela valoriza (apesar do "muito trabalho e pouco dinheiro") pois reconhece aí uma oportunidade de um aprendizado contínuo: "Mas por outro lado, é gostoso porque todo dia você vê gente, tem umas que estão de bom humor, tem outras que estão de mau humor. A vantagem do comércio é essa: todo dia você vê gente

\footnotetext{
111 De fato, da primeira entrevista, eu lembrava de Suely com uma espécie de "dureza", que tinha a ver com a sua assertividade em relação a alguns aspectos de sua trajetória. Na segunda entrevista, no entanto, Suely estava bem mais tranqüila, mais suave - tinha um brilho diferente.

$112 \mathrm{Na}$ visita que fiz à sua casa, para a realização da segunda entrevista, Suely fez um delicioso suco de mamão e laranja, com as frutas que trouxera do supermercado. Ela não traz os alimentos só para si, fazendo uma distribuição entre as vizinhas mais próximas ou entre aquelas que ela sabe que estão precisando.
} 
diferente, você tem como conversar, escutar as pessoas. Você não tem como falar os seus problemas, você nunca tem problemas, né? Mas é legal, você aprende bastante coisa".

Em sua trajetória, chama a atenção a disponibilidade para encontrar formas alternativas de ganhar dinheiro. Antes de entrar no posto, ela abriu uma bombonière; após sair do posto, resolveu construir cômodos para alugar: "Quando eu saí do posto, (...) eu falei "Sabe o que eu vou fazer?" - falei para mim mesma - eu vou construir casas e vou alugar. (...) E aí o que eu fiz? Eu fiz dois cômodos, aí mudei para os dois cômodos. Aí eu fiz mais dois cômodos, aluguei os dois em que eu estava e passei para o outro. Aí o dinheiro que eu consegui de rescisão, eu tinha of fusca, vendi o fusca para ajudar".

Em parte, como ela mesma reconhece, a possibilidade de adotar estratégias que não implicam em uma remuneração imediata (abrir negócios, construir cômodos, fazer cursos) está ligada a existência da pensão que recebe de seu ex-marido e do pai de seu filho mais novo. Após a construção e o aluguel dos cômodos, a situação ficou ainda melhor: "Nossa,(...) às vezes eu fico pensando, nossa, eu estou no céu. É um pouquinho daqui, é um pouquinho dali, é pouco, mas o pouco se torna...Não é que se torna muito, mas para mim está ótimo. Às vezes eu não gosto de nem falar alto (...) tanto é, que se for para mim viver uma vida assim, razoável para pobre, dá para mim ficar sem trabalhar. Não sei até quando...porque o meu filho mais velho ganha pensão e vai ganhar até o ano que vem; eu tenho dois aluguéis (...), mais a garagem (...) e o pequeno também ganha pensão".

De outro lado, existe o impulso para melhorar a vida, para melhorar a sua condição e a condição dos filhos e é nesse sentido que é possível reconhecer a especificidade da história de trabalho de Suely.

Para ela, ter um trabalho, ter uma profissão, nunca foi um sonho; tratava-se de uma necessidade. E para satisfazê-la, não era preciso muita dedicação: "eu lembro que os meus pais falavam que a gente tinha que estudar para ser alguma coisa $e$ trabalhar de qualquer coisa. Eu lembro isso. Agora se era dificil arrumar emprego antigamente, não era. Ah, Não era. (...) Então, não era difícil, então, não posso falar para você que os meus pais falavam "é difícil emprego, vamos estudar". Com quarta série primária você conseguia emprego ou às vezes até...às vezes, não, analfabeto conseguia emprego. Hoje em dia você tem o ensino médio e não arruma emprego". 
É quando se separa, quando se vê sozinha com a responsabilidade de zelar pelo presente e pelo futuro de sua família, que Suely passa a colocar o trabalho numa outra posição: não mais a garantia da independência em relação ao marido, mas o instrumento de conquista das coisas - uma casa melhor, possibilidade de pagar a escola do filho e cursos complementares - cujo custo, antes, podia ser dividido. Para Suely, o trabalho aparece como um signo de sua nova condição: "dona de casa, sozinha e separada".

Ao mesmo tempo, o trabalho tem importância como ocupação do tempo. Suely relata que, durante o tempo de desemprego, pensava muitas besteiras por dispor de muito tempo livre. Agora, com a volta ao trabalho, parou de se preocupar tanto, vencida pelo cansaço do trabalho: "sei lá,(quando está parada) a gente fica pensando besteira; quando dá uma dorzinha na gente a gente já pensa que é coisa de outro mundo, eu sou desse jeito, sabe? Já penso...Nossa, teve uma época que eu me sentia...olha, eu achava que eu estava com câncer, vixe...eu saía para procurar, eu não dormia de noite, achava mesmo. (...) Eu sofri demais essa época, sabe, entrar em depressão, assim? De não dormir, de ficar mal mesmo... porque você ocupa a mente só com besteira, né? Acho que é aí porque, por exemplo, eu não trabalhava, estou trabalhando, eu tenho um problema no joelho, há muitos anos que eu tenho, meu joelho está doendo, desde que eu comecei a trabalhar, começa porque eu pego caixa pesada lá e eu estou gorda também, estou pesada, meu joelho começou a doer. Mas eu não tenho tempo para ir no médico, você não está preocupado, você não tem tempo, não está preocupado. Essa semana agora que eu fui no médico e o médico falou: "É porque você pega caixa pesada e porque...mas o seu joelho está bom, você tem que forçar um pouquinho menos", né? Agora, se eu estivesse dentro de casa, eu já achava no mínimo que eu estava com osteomielite, alguma coisa assim eu já estava achando, né?"

\section{A experiência do desemprego prolongado}

Na primeira entrevista com Suely, como já apontei, ela estava desempregada há um ano e nove meses.

Como relatado acima, após a saída do posto, Suely decidiu usar suas economias para construir cômodos e alugá-los, numa estratégia clara de acumular "coisas" que tornassem menos vulnerável a sua condição. 
Ainda nesse meio tempo, havia voltado à escola, para fazer o ensino médio: "voltei no ano passado, (para fazer) o primeiro, no meio do ano. Faço suplência". A decisão de voltar a estudar foi, em parte, possibilitada pela demissão, já que, como ela apontou, a conciliação entre trabalho e estudo era impossível: "para ser bem sincera para você eu achava assim, eu queria assim, ou você estuda - para mim, né, com filho - ou você estuda ou você trabalha; que se você pode só estudar, tudo bem, se você não pode, só trabalha porque não dá para conciliar as duas coisas. Eu comecei, voltei a estudar porque eu fiquei desempregada por nove meses e não consegui arrumar emprego, aí eu falei "Vou ter que voltar a estudar". Por causa disso já perdi uma vaga de... duas vagas para trabalho porque saía muito tarde eu falei "Não, eu vou botar na minha cabeça que eu vou estudar; enquanto eu puder segurar de uma ou outra forma".

A conciliação de duas atividades aparece como impossível - e ela nota que sua condição de mãe complica ainda mais a situação. No momento em que perde o emprego, e, principalmente, à medida que o tempo de desemprego se prolonga, Suely se vê obrigada a voltar a estudar, construindo para si novos atributos que lhe permitam, ao menos, ter chances de voltar a trabalhar. Assim, recusa propostas de trabalho para completar os estudos, revelando a percepção de que, em um determinado momento, mais importante do que estar trabalhando é adquirir as aptidões necessárias ao trabalho.

Suely listou algumas razões para o seu desemprego: "eu acho, primeiro: pela minha falta de conhecimento, ou seja, a escola, algum curso assim específico, ou seja, o mercado de trabalho está exigindo muito. Não adianta você ter experiência, tem que ter escolaridade e, tem que ter um curso de inglês no mínimo, espanhol, informática, né? Eu tenho um conhecimento básico de informática, mas eu não tenho nenhum curso, que eu possa falar "Tenho isso" (...)E também porque, a minha idade, tenho 36 e vou fazer 37. Segundo, os filhos e para ser bem sincera para você, eu estava lendo um jornalzinho, que eu sempre pego para ler, e estava alguma coisa relacionada à obesidade que hoje em dia tem muito preconceito. Então, por eu ser assim, já obesa, tudo isso influi. Quando eu era mais nova, tinha um corpo melhor, eu tinha melhor aparência, era mais fácil para arrumar emprego - em loja...Porque a você atender o público, você tem que ter uma boa aparência, não adianta você saber conversar". 
Como primeiro fator, Suely reconhece - como sua estratégia de retorno à escola havia mostrado - a deficiência da escolaridade. Em seguida, levanta alguns aspectos relativos à qualificação, tais como cursos de línguas, informática...O interessante é que tais aspectos aparecem (e não apenas na fala dela) como importantes em si mesmos. Menos que denotar competências específicas e relacionadas ao trabalho, eles revelam a disposição e o empenho em se preparar para o trabalho, seja ele qual for. O acúmulo de cursos não tem como objetivo a conquista de uma posição melhor mas, simplesmente, construir possibilidades para a continuidade da inserção.

Finalmente, idade e obesidade aparecem como fatores de explicação para o tempo prolongado de desemprego, numa operação de culpabilização pela própria situação. Apenas em um momento posterior da entrevista é que Suely trouxe à tona uma crise mais geral como fator explicativo para as dificuldades encontradas: "Mas eu não sei, sabe, até ontem a menina estava comentando comigo, passou na televisão engenheiros trabalhando de camelô, né? Pois é. Há dois anos atrás, quando começou essa frente de trabalho em São Paulo, eu vi que estava na fila para ser gari, um engenheiro. Quer dizer, não é só para mim que está difícil, está difícil para todo mundo. Não é só por causa da crise, quer dizer da falta de conhecimento, é por causa da crise mesmo. A crise que está aí, é mundial, não é só aqui, é em vários países, é mundial".

Na segunda entrevista, perguntei a ela sobre a crise e suas conseqüências para o desemprego e as possibilidades de trabalho. Para minha surpresa, Suely passara a atribuir significados para a crise que reforçavam a responsabilidade do trabalhador: "mas eu acho que eu estou errada, porque é assim: se eu tivesse mais na ativa, se eu tivesse mais, é...estudado, fizesse mais curso, mais, sabe, me empenhado mais em aprender mais, né? Quanto mais a gente aprende melhor e a crise está ruim por que? Porque está exigindo mais".

Assim, o prolongamento do tempo de desemprego levou Suely a significar a crise como a incapacidade dos trabalhadores em acompanhar as exigências de um mercado de trabalho progressivamente mais competitivo. Não importa que ao aumento de sua escolaridade não tenha correspondido a consecução de um emprego - "Inclusive estudei um ano e meio, só que eu não arrumei emprego" - ou um aumento de salário (como ela conta, o que se deu foi o contrário). A circulação da necessidade da 
aprendizagem constante para a construção da empregabilidade atravessa sua maneira de entender a realidade, a despeito de sua própria experiência.

Durante a primeira entrevista, Suely contou sobre a organização de seu tempo: "por exemplo, que dia que foi? Foi terça-feira, eu vim para cá, saí daqui era nove e vinte, fui distribuir os currículos e até às $11 \mathrm{~h}$ fiquei distribuindo currículos, voltei de novo para o SERT, que é uma outra coisa parecida com essa, tinha pegado uma senha lá. Esperei até meio dia e quarenta e faltavam 84 pessoas mais ou menos para eu ser atendida. Eu tinha uma audiência, eu tinha um encontro com a advogada, que está vendo o fato do meu ex lá estar querendo abaixar a pensão, aí eu tinha marcado um encontro com ela. Quer dizer, então eu não podia ficar mais ali, tive que deixar aquilo para trás. Aí eu corri para lá e cheguei lá e ela não estava, esperei ela chegar e nada; morta de cansada e com fome, só tinha tomado café da manhã, conclusão: eu fui para casa. Chego em casa e com certeza o meu filho já almoçou na minha vizinha ou na casa da minha cunhada; porque se não deu tempo de eu chegar até a hora do meu filho mais velho ir para a escola, eu ligo para ele, de onde eu tiver, falo "Você dá o almoço, veja se fulano dá para ficar, se não der deixe com o sicrano e fala que eu vou demorar para chegar". Então é assim, aí eu chego em casa e faço o meu serviço, alguma coisa que eu tenho que fazer, até chegar a hora de eu ir para a escola. Geralmente assim. Que todo dia tem alguma coisa para eu fazer, se não é na rua, é na minha roça. Porque eu tenho uma rocinha dentro de casa, então é isso aí, sempre tem alguma coisa para fazer. Geralmente eu nunca fico sem fazer nada".

O movimento incessante, o "sempre ter alguma coisa para fazer" são constantes na fala de Suely e aparecem tanto na descrição de seu período de desemprego quanto na descrição de seu cotidiano atual. Desse modo, ainda que à primeira vista essa agitação parecesse característica da situação de desemprego aberto - as "correrias", tão comuns às pessoas em situação de desemprego aberto -, ela é, de fato, expressão da condição feminina de Suely, de seu esforço por conciliar os cuidados com a casa, os cuidados com os filhos e as atividades de trabalho ${ }^{113}$. Definir-se como "parada", como fez Fátima, seria impossível para Suely, pois ela reconhece que o trabalho desempenhado dentro de casa, embora não remunerado, (muitas vezes nem reconhecido), também é trabalho e um trabalho que não tem fim - "Mas a mulher

\footnotetext{
${ }^{113}$ Há extensa literatura refletindo sobre a dupla jornada feminina. Para análise mais detalhada ver, por exemplo, Rodrigues (1978), DIEESE (1999) e Sarti (1985).
} 
trabalha mais do que o homem, né, porque a mulher trabalha fora e dentro de casa., só quando a mulher não trabalha, que hoje ela vive as duas...vive de trabalhar fora e dentro, e já vivia de ficar dentro de casa. A mulher que fala "ah, meu marido acha que eu não faço nada dentro de casa, mas a mulher faz, mas...Quando ela trabalha fora e dentro, só trabalha".

Suely falou das diferenças existentes na experiência que homens e mulheres fazem do desemprego: "no caso, se tem os dois dentro de casa, né? Diferente assim, porque a mulher, ela estando desempregada, ela faz qualquer bico, qualquer coisinha ela faz dentro de casa para sair alguma coisa de dinheiro, né? Agora o homem não, o homem estando desempregado, ele, nossa! Acho que ele se sente...Eu vejo pelo meu irmão, esse que me indicou para mim levar o currículo lá, ele ficou desempregado, ele queria até ir para o Japão, sendo que ele não pode. Sabe? (ele queria) colocar, ELE colocar o dinheiro dentro de casa, não ficar dependendo o tempo todo da mulher. Ele ficou mais de um ano desempregado também, né? Então, ele ficou, nossa, meio alucinado, falava coisas que não tinham nada a ver. A gente ficou preocupada já com ele, para você ter uma idéia. (A mulher) vende um avon, em casa, ela faz um crochê, ela faz uma pintura, ela inventa um curso, ela inventa um curso de...qualquer coisa a mulher faz, para comprar as coisas dela. Agora, o homem, não. O homem, as contas têm que ser pagas praticamente tudo por ele. Não é assim, exatamente, mas...".

Chama a atenção que ela construa a diferença tendo em mente a divisão de papéis entre um casal - sobre o homem, apesar de todas as mudanças ocorridas na sociedade e nas famílias, recai a responsabilidade de sustento da casa; à mulher, resta a imaginação para pensar em outras estratégias para ganhar dinheiro, uma vez que seu dinheiro, geralmente, é para si mesma ou empregado para a melhoria da casa ${ }^{114}$.

Quando a situação se refere a uma mulher sozinha, responsável pela casa, a situação se modifica radicalmente: "Quando a mulher no caso é separada, ela fica louca mais rápido. Acho que ela fica louca mais rápido porque não tem ninguém para ajudar ela, né? Aí...eu acho que ela dá um jeito de arrumar um outro emprego rapidinho porque tem que arrumar. Ou é faxina ou casa de família, a mulher tem que fazer. Não no meu caso porque eu

\footnotetext{
114 Maria Inês Caetano, analisando trajetórias femininas de mulheres residentes numa grande favela, em São Paulo, encontrou muitas trajetórias nas quais o impulso para a entrada no mercado de trabalho aparecia ligado à autonomia de comprar suas próprias "coisinhas", sem precisar da autorização do marido. Além disso, chamando a atenção para a descontinuidade de tais trajetórias, Caetano afirma "(...) que o freqüente abandono do emprego a favor das obrigações domésticas se justifica porque as atividades profissionais não são um projeto para estas mulheres" (Caetano, 2004: 326).
} 
já te falei, eu tenho de onde tirar, é pouco mas tem. Mas quando não tem nada...(...) Mas...se, por exemplo, eu tenho uma inquilina aqui que trabalha em casa de família, ela ganha $R \$ 450,00$. Ela paga duzentos reais de aluguel, paga, esse mês veio $R \$ 21,00$ de conta de luz para ela e $R \$ 7,00$ de conta de água. Você coloca tudo isso na ponta do lápis, é remédio, que fica doente, é material de escola... O salário dela é todo para isso, se ela for mandada embora, o que ela vai fazer?". Os significados do desemprego, assim, estão diretamente ligados ao papel vivido fora do trabalho e às responsabilidades assumidas e incitam a que se encontre rapidamente uma alternativa, que não necessariamente tem a ver com a identidade profissional. Ao contrário, os exemplos tomados por Suely são reveladores: qualquer serviço que apareça, a mulher tem que fazer. A necessidade de manutenção da casa a obriga a se sujeitar ao desempenho de atividades que, normalmente, ela não aceitaria ${ }^{115}$.

O último ponto sobre o qual é importante chamar a atenção, no que se refere à experiência de desemprego de Suely, refere-se à perda das esperanças de conseguir um novo trabalho, provocada pelo desgaste de sair, procurar, entregar currículos e não encontrar um novo trabalho: "Também teve época que eu parei porque eu cansei, sabe, você desanima, você sai, você procura e não acha. Eu fiquei, acho que mais de seis meses sem procurar emprego, no mínimo. Sem procurar, eu falei "Eu não vou procurar mais", aí fiz curso de manicure, fiz curso de depilação".

O tempo prolongado de desemprego, assim, acaba por afastar Suely do mercado de trabalho, não porque ela deixe de desejar um novo emprego, mas porque acaba desalentada, sem enxergar possibilidades de reinserção que justifiquem o esforço e o desgaste da procura.

Mais do que isso, Suely relata as conseqüências do longo período de desemprego até mesmo quando se encontra um novo emprego: "quando a pessoa começa a trabalhar, eu sou assim, eu fico com medo, eu quero demonstrar serviço para o patrão porque parece que está sempre observando o que eu estou fazendo. Depois não, eu sou assim, depois eu acostumo com ele e então eu faço meu serviço, independente se ele está ali

\footnotetext{
${ }^{115}$ Sobre isso, mais uma vez Hirata e Humphrey mostram as diferenças entre operárias casadas e com filhos, operárias solteiras e operárias mães solteiras, observando que entre aquelas que são mães, a disponibilidade para a aceitação de um trabalho, ainda que fora do setor de origem ou aquém da qualificação, é bem maior, (Hirata e Humphrey, 1989a).
} 
olhando ou não, então eu me acostumo com ele e não ligo mais. E isso daí é bom. Porque se você faz uma coisa, sentindo que está pressionada, é mais fácil de você errar do que se você fizer natural, né? Acho que é isso. (...) Eu sou de brigar, pegar no pé do pessoal falar assim que "Gente, vamos trabalhar" e o pessoal fala "ai, é puxa-saco", mas não é questão de ser puxa-saco, a questão é que um dia o pote seca". O medo de voltar à situação de desemprego acaba tendo conseqüências sobre o trabalho, contribuindo para a adesão às necessidades e valores da empresa ou do patrão. Ao invés de uma relação de troca - de compra e venda de força de trabalho -, estar empregado aparece como uma "dádiva", a qual é preciso agradecer por meio de um comportamento exemplar. É preciso vigiar pois que, um dia, "o pote seca" 116.

\section{Mulher, sim: mas o que é isso mesmo?}

Um aspecto bastante interessante que apareceu na fala de Suely, desde a primeira entrevista, refere-se ao seu esforço de se afastar dos gostos e hábitos reconhecidamente femininos. Assim, quando perguntada sobre o que fazia em seus momentos de lazer, ela respondeu: "olha, parece mentira, né? Porque geralmente as pessoas, quando a gente vai fazer uma entrevista, a pessoa fala assim "e o seu lazer, o que você gosta de fazer?", eu não gosto de assistir, geralmente, novela. Eu não gosto de novela. Se for para mim assistir, eu quero assistir um filme. Eu gosto de assistir jornal - não por eu gostar do jornal, mas porque eu preciso do conhecimento, do que está acontecendo. Até mesmo por esses concursos, que eu geralmente presto, concurso público, eu gosto de estar por dentro, quando passa alguma coisa que eu acho interessante, Globo Rural eu gosto de assistir, Globo Repórter - eu adoro - esporte, eu gosto de assistir, sabe? Essas coisas assim, que eu acho que me instrui mais do que novela, desenho ou uns filminhozinho assim, que eu acho que não tem importância".

\footnotetext{
116 Paul Singer trata da confusão que permeia as relações de trabalho sublinhando o efeito ofuscante que a expressão "dar empregos" possui: "Para colocar o desemprego em perspectiva, é necessário explicitar e examinar criticamente uma série de pressupostos que o discurso corrente subentende. Em primeiro lugar, o fato de que se necessita de ocupação, que não é sinônimo de emprego. Este ultimo conceito implica em assalariamento - uma relação de emprego só existe quando alguém, em geral uma firma, dá um emprego a alguém. (...) Não há qualquer "dação", mas compra e venda. (...) Os empresários gostam de falar de oferta de emprego, como se o emprego fosse alguma dádiva que a firma faz ao empregado. Na realidade, é o contrário: é o trabalhador que oferece, ele é o vendedor, e a mercadoria não é o emprego mas a capacidade de produzir do trabalhador" (Singer, 1998: 12).
} 
Embora a ênfase que Suely dá, em sua fala, refira-se ao problema da aprendizagem e da instrução, a maneira pela qual introduz a questão é que dá a pista de que - em sua forma de entender - existe algo de "estranho" em seus gostos, algo que poderia fazer com que sua fala passasse por mentira117.

Essa recusa ao que parece próprio do mundo feminino fica ainda mais clara quando ela relata as situações vividas nas filas, à procura de emprego: "Eu acho muito...Primeiro eu observo, né? Eu observo as pessoas, se começar a falar alguma coisa que eu acho que é do meu interesse - porque, honestamente, eu acho que em fila, num local público, não é tudo o que se pode falar, né? Aí, geralmente, se é alguém que está falando, assim, da família dela...Para ser bem sincera, as mulheres que falam mais, né? Começa a falar muito da sua vida dentro de casa, gente que só tem aquele... começa a falar muito de si, para todo mundo ficar sabendo, eu não abro a boca, prefiro não manter assim um contato. Agora, se a pessoa fala do em geral, do que está acontecendo, aí é até bom, é um conhecimento para a gente estar sabendo das coisas. Então eu gosto".

Existem alguns elementos nessa fala que merecem destaque. $\mathrm{O}$ primeiro deles se refere à distinção entre público e privado, operada por Suely: existem lugares específicos para cada tipo de conversa e, em sua reprovação, ela demonstra conhecer a adequação entre temas e lugares. O segundo se relaciona com a impaciência que ela tem com as mulheres que não têm outro assunto que não sua vida dentro de casa.

Embora Suely esteja se referindo a um conjunto imaginário de mulheres, sua fala não deixa de conter uma crítica mais geral à condição feminina: ela reconhece uma espécie de confinamento no espaço da casa, que acaba determinando o repertório de assuntos à sua disposição. Não à toa, Suely contrapõe aos temas discutidos pelas mulheres, os temas conversados pelos homens: “(...) os homens, se eles falam, nossa... eu adoro conversar com um homem porque é tudo coisa aproveitável. Eu gosto. (...) eu jogo vôlei na rua com os moleques, né, enquanto as minhas vizinhas ficam conversando. Eu não tenho paciência, às vezes (elas falam) "Vem cá Suely, vamos tomar uma cerveja aqui", eu tenho amizade com um monte de gente, mas você vê, a minha vizinha da frente, eu converso mais com o marido dela do que com ela. Entre as minhas irmãs e os meus

117 Como Suely mostra, nessa fala e mais à frente, quando estiver tratando das dificuldades de conseguir emprego sendo mãe, as mentiras que se conta revelam o mundo da forma como imaginado, da forma como "deve ser". 
irmãos, converso mais com os meus irmãos do que com as minhas irmãs. Então é assim, eu brinco com a molecada, jogou vôlei na rua mas eu não perco meu tempo falando com as menininhas, para conversar sobre namorado e isso e isso. Eu sou desse jeito, não sei porque".

Os temas de conversa e as atividades realizadas pelos homens - desde pequenos, já que ela também prefere brincar com os colegas do filho a ficar "perdendo tempo" conversando com as meninas sobre namorados - são valorizados, assim, por Suely, dando notícia de sua inconformação aos limites que reconhece como impostos às mulheres. Suely não está interessada em permanecer no espaço da casa e é por isso que, a despeito de não necessitar, gosta de trabalhar, tendo contato com o público, aprendendo cada dia um pouco mais. Trata-se de um interesse pelo mundo que recusa o confinamento no espaço da intimidade.

Também nessa valorização no mundo da rua, Suely se diferencia dos outros entrevistados. Mas não se deve perder de vista que ela é a única que voltou a trabalhar (legitimando, assim, seu trânsito pelo espaço da rua). Ademais, sua fala revela mais uma valorização do mundo masculino - e sua independência em relação ao mundo da casa, sobre o qual ela projeta o confinamento e a restrição de um cotidiano dominado pela reprodução e pela sobrevivência. Assim, sua fala revela mais uma valorização do espaço público de encontro e troca do que do "mundo da rua" em si; tanto é que ela valoriza o espaço da casa como o lugar da intimidade e da preservação em relação ao controle de vizinhos.

Deve-se notar que essa postura não deve facilitar a vida de Suely, já que, sendo mulher, separada, mãe de dois filhos de pais diferentes - "o primeiro foi do casamento $e$ o segundo de uma alucinação, assim. E aí resolvi ter, não é?"- é bastante possível que a adesão ao universo feminino da casa e das conversas com vizinhas a inserisse numa rede de solidariedades. Por outro lado, a proximidade com os irmãos e irmãs também pode funcionar como uma rede de proteção bastante forte, o suficiente para sustentar sua postura de reserva em relação às vizinhas e de contatos mais freqüentes com os vizinhos.

Suely procurar preservar sua vida e o espaço da casa e é por isso que, quando perguntei a ela se chegara a sentir algum tipo de cobrança durante seu período de desemprego, por parte de parentes ou vizinhos, ela sorriu, dizendo: "Mas não pode; $o$ 
pessoal não pode cobrar nada de mim. Não pode cobrar nada. Não, não escutei, eu não sou muito assim de dar muita trela para o que vizinho fala, entendeu? Eu não tenho assim esse hábito de ficar conversando com os vizinhos, sabe, ter muita amizade. Entre ficar na rua conversando com vizinho ou a vizinha ficar na minha casa, eu prefiro ficar dentro de casa assistindo televisão. Então, esse negócio de vizinho ficar cobrando, eu não...".

\section{Ser mãe e trabalhar}

Durante a primeira entrevista que fiz com Suely, sem querer acabei fazendo uma importante descoberta a respeito dos esforços necessários à conciliação do papel de mãe e trabalhadora.

Já estávamos conversando há algum tempo quando perguntei a ela se seu filho mais velho - na época com 16 anos - cuidava de seu filho mais novo - então com 3 anos - enquanto ela saía para procurar emprego. O rosto de Suely se fechou, ela ficou em silêncio por alguns instantes, meio desconcertada e em seguida disse: "olha, não fica. Eu chegar numa entrevista, e a entrevistadora do trabalho (perguntar) "Com quem é que fica seu filho mais novo?", sinceramente eu vou dizer para você que fica com a minha mãe. Mas a minha mãe nem mora aqui mais, mora no interior de São Paulo. Mas para gente falar que o filho está na escolinha, eles já ficam com um pé atrás, "Qualquer probleminha, ela já tem que sair, ir lá". Então, eu prefiro dizer que fica com a minha mãe, porque o meu filho mais velho, ele estuda a parte da tarde, período da tarde. Então, ele estuda numa escola particular, eles fica 6h na escola; então, não dá para mim dizer para você que o meu filho mais velho cuida do mais novo, agora (de manhã) estão em casa os 2; mas à tarde, ele deixa com a minha vizinha, se eu não cheguei ainda, ele deixa com vizinha ou deixa na casa do meu irmão, que a minha cunhada fica em casa, né? Mas, se eu arrumar um emprego, sim, coloco ele na escolinha ou pago alguém para olhar".

A mentira contada é reveladora das representações de realidade que operam na prática: Suely reconhece que a maternidade é encarada, pelos empregadores, com um obstáculo ao bom desempenho das funções. Assim, para ser mãe e trabalhar, é preciso contar - ou fingir contar - com uma rede de proteção mais forte do que aquela possibilitada por relações contratuais. Assim, não adiantam a babá ou a escolinha. É preciso contar com alguém que verdadeiramente se responsabilize pelos cuidados com a criança, "amortecendo" o efeitos dos imprevistos sobre o trabalho: 
"porque com a avó, a avó tem mais facilidade de levar ao médico, qualquer probleminha a avó vai resolver porque tem que defender a filha porque a filha precisa trabalhar, né? Agora, a babá, ela não vai se preocupar em ficar levando no médico porque a função dela é cuidar da criança, não é ficar levando no médico; e a escolinha muito menos... (...) vai chamar o responsável, no caso a mãe".

A representação do "empregado ideal", desse modo, aliada à consciência de sua condição de mãe solteira fez com que Suely elaborasse uma estratégia para aumentar sua empregabilidade, a despeito de sua condição. Ela relatou que começou a contar essa mentira a partir de suas observações do tipo de pergunta feita pelos selecionadores.

É importante notar que a mentira "contada" não tem como objetivo explícito "enganar" ou "levar vantagem". Trata-se de uma estratégia para superar a barreira percebida por uma atenção aos mecanismos sociais em operação: a "mentira", nesse caso, é reveladora de uma consciência aguda dos limites e possibilidades oferecidos pela conciliação de seus diferentes papéis e também da crítica que Suely faz a tais limites e possibilidades. Suely sabe que a maternidade não a dispensa de trabalhar; ao contrário, é o que a impulsiona para o mercado de trabalho. Ao mesmo tempo, a maternidade, quando não apoiada por uma rede de relações pessoais - por isso mais estáveis - torna-se um fator complicador pois que, na interpretação dos empregadores, parece tornar o trabalho mais vulnerável às eventualidades do cuidado com as crianças. Suely, então, mente, para construir para si a imagem da "trabalhadora ideal", mãe, mas livre das obrigações com seus filhos.

A conciliação dos papéis não se faz sem um certo sacrifício de toda a família. Durante o tempo em que trabalhou como conferente em Moema, por exemplo, precisou dormir alguns dias por semana no serviço, a fim de economizar o dinheiro do vale-transporte, e para que isso fosse possível, algumas mudanças tiveram que ser feitas: "Seria muito bom (o emprego) se meu patrão não fosse sem educação, porque ele não respeita os funcionários e apesar de ser longe, ainda eu deixava o meu filho sozinho...O maior ficava sozinho, tomava conta da casa - imagina a maravilha que era casa... - e o pequeno ficava com a minha irmã, em Carapicuíba. (...) nós ficamos assim, eu dormia duas ou três noites aqui em casa, duas ou três noites lá no serviço e uma com ele, na minha irmã". 
Ainda hoje, para que Suely possa trabalhar fora, é preciso dividir as tarefas domésticas com o filho mais velho - e essa divisão não se dá sem conflitos: “O Juliano adora, né (que ela tenha voltado a trabalhar)? Fico menos em casa, brigo menos com ele, tudo isso. Mas a cobrança, assim, do serviço é a mesma: ele tem que chegar da escola, e a função dele é, a primeira coisa que ele faz, sempre quando chega faz, é arrumar a minha cama; depois do almoço ele dá uma descansadinha e a primeira coisa é arrumar a minha cama. Eu deixo o Luciano dormindo ainda. E ai ele lava a louça. O que ele mais faz é assim, a casa, a casa é para ele: o chão, os móveis, os banheiros...Então, não adianta, ele estudando, ele chega e já faz. A gente briga muito por causa disso ainda, inclusive eu estou, essa semana, acho que foi sábado, ele falou assim para mim "quando eu começar a trabalhar, eu não vou fazer mais nada aqui em casa, também". E eu falei "se você ganhar bem e puder pagar uma empregada para fazer, beleza! Se você ganhar pouco, igual a sua mãe, você vai continuar fazendo".

Por ocasião da segunda entrevista, quando Suely já estava trabalhando, a conciliação dos papéis ainda aparecia como foco de inquietação, pois mesmo o esforço de arranjar as coisas de modo que os filhos não sofram está sujeito às vicissitudes. Ao falar sobre este assunto, Suely se emociona, os olhos ficam vermelhos e a preocupação é evidente: "Trabalho de manhã, trabalho mais no período da manhã, eu saio às 15h. Inclusive, eu estou com problema, a menina que começou a olhar ele faz, a bem dizer começou quinze dias, começou no dia 3, arrumou um emprego hoje; quem vai passar a olhar ele é a tia dela, que mora na mesma casa, ela mora na casa da tia. Então, ela falou, você conversa com o Luciano porque o Luciano é muito peralta, o Luciano é isso, isso, isso e isso... e eu falei "Pelo amor de Deus, Luci, você olha ele porque se você não olhar ele, ele vai ficar trancado dentro de casa, vai ficar em casa trancado por que eu preciso trabalhar".

A maternidade aparece, então, no que se refere às relações com o trabalho, como uma fonte de preocupação constante, o que fica mais claro quando Suely, tomando a função de frentista como exemplo, explica as razões pelas quais as mulheres, principalmente as com filhos, encontram mais dificuldades em encontrar trabalho: "Há um tempo atrás, nossa, era novidade, mulher de frentista, e todos os postos queriam ter frentistas mulher, né? Por que chamava os clientes; aí, as mulheres, meio que sem querer ou umas aceitam uma cantada, aí o cliente, já não deu certo, já olha de cara feia, eu vejo isso mesmo no posto onde eu trabalhava... Já olha de cara feia, já não gosta. Ou são determinados serviços que a mulher não quer fazer, se começa sujar a unha do esmalte, mas já não quer e os 
homens não, não ligam para isso. Também o fato de a mulher ter filhos, ter o tempo que tem que ficar em casa, cuidar do filho, com essa preocupação de estar trabalhando e estar pensando no filho, se o filho fica doente tem que sair...Então, com certeza, eu acho que mais dificil para mulher".

Na segunda entrevista, perguntei se ela acreditava que se preocupar com o que acontecia em casa, com os filhos, estando no trabalho, era uma exclusividade feminina e ela respondeu que sim, "porque já vem da mulher mesmo, eu acho que ela se dá mais para a família e para os filhos, ela gosta de ter as coisinhas dela e o homem é mais para o bruto, você não vê o homem falar assim: eu preciso comprar um liquidificador para dar para minha mulher, preciso comprar um... sei lá, uma batedeira para mim fazer um bolo. Imagina, se homem mora sozinho ele não tem nada disso, o básico que ele pode ter é o fogão, a geladeira pode até ter... mas ele não vai ter uma batedeira, não é? O homem não pensa em comprar enfeitezinho para colocar em cima das coisas, não põe, o homem não pensa "ah,vou comprar uma bolacha para meu filho, um iogurte para o meu filho, uma roupinha mais bonita para o meu filho", tudo isso, eles não se preocupam com isso, não tem essas coisas. Se é frescura ou não, é da mulher".

A preocupação, portanto, aparece aqui como um atributo feminino - o que reforça a interpretação de que o "nunca descansar" de Suely se relaciona com esse cuidado permanente com a casa e os filhos, além do trabalho executado fora de casa. Segundo ela, as mulheres não se desligam das preocupações da casa nem quando estão trabalhando, pois desejam garantir mais do que a sobrevivência: desejam garantir também "as frescuras", tais como instrumentos que facilitem sua vida, enfeites para tornar a casa mais bonita e "supérfluos" para os filhos.

Retomando a fala já citada, em que Suely diz que se estivesse interessada em levar uma vida "razoável para pobre" não seria preciso trabalhar, ela continua, afirmando "Mas não é só isso que eu quero: meu filho precisa do inglês, ele quer o inglês e eu vou começar a pagar para ele esse ano; eu quero fazer um curso de computação. Ele já falou para mim, "não, mãe, eu ensino a senhora, em casa mesmo, a gente liga o computador" e eu não quero assim, eu quero aprender na escola, porque se for assim, eu não faço. Eu não tenho tempo, eu não tenho, eu não vejo tempo. Agora, não, eu vou pagar, e aí é uma, duas vezes por semana, aí eu vou. Mas do jeito que ele quer, eu não quero. E outra, eu preciso terminar a minha casa! Preciso terminar a minha casa, preciso de um fusca para mim, um outro fusca 
para mim, tudo isso e a gente está precisando sempre trabalhar... exatamente, comprar o que a gente quer, né? E já é difícil assim trabalhando, imagine sem trabalhar...".

É dessa maneira que a condição materna, ao mesmo tempo que é fonte de inquietações, também é impulso para o mundo do trabalho - justamente com o intuito de superar as limitações impostas pela pobreza: "eu só sei que eu estou aí para trabalhar (...) De um tempo para cá, que eu comecei a precisar do emprego - que eu sempre gostei de trabalhar, mas como as vezes você não precisa tanto de dinheiro, você não tem tanta motivação; hoje em dia eu tenho responsabilidades do meus filhos, né? Então, eu dou o sangue pelo emprego, já fui até trabalhar várias vezes doente, por causa daquilo...".

\section{Jovialidade e aparência: preconceitos}

Assim como descrevi ao introduzir a história de trabalho de Suely, um dos aspectos levantados por sua narrativa está relacionado à questão da aparência. Ao dizer que não encontrava emprego devido à idade e à obesidade, Suely pôs a nu um problema que apareceu diversas vezes nas entrevistas que fiz com mulheres, principalmente entre aquelas cuja função ou profissão exigia o contato com o público ${ }^{118}$.

Como forma de vencer este obstáculo, ao mesmo tempo em que continuava procurando, Suely também prestava diversos concursos: "Eu estou prestando concurso para qualquer coisa; inclusive, há mais ou menos uns dois anos eu cheguei a passar num concurso, fui chamada, mas naquele período eu não tinha carta de habilitação $C$, eu tinha a B,

\footnotetext{
118 Recupero um caso bastante significativo, relatado por Edite, 49 anos, negra. Sua filha de 20 e poucos anos, com ensino médio completo, chegou até a fase final de uma seleção. Na última entrevista, a selecionadora disse para ela que, entre ela - negra e gordinha - e a outra menina, menos escolarizada mas branca e magra, ficaria com a outra menina. Edite contou que a filha deixou de procurar emprego por mais de seis meses, só tendo retomado a procura após o início de um tratamento terapêutico. Há ainda um aspecto interessante no relato de Edite. Ao terminar de contar essa história, ela me lançou um olha resignado e disse "É, minha filha, para você ver". Comentei então que se tratava de uma grande violência, com o que ela concordou e depois emendou relatando o desdobramento da história: disse que pensou em ir até a empresa, encontrar a selecionadora: "eu podia ir lá (...) porque você é escura, mas você também é gente, você também saiu do mesmo lugar, faz as mesmas coisas...(...) Aí depois de tempo eu falei: "ô,. Alice, acho que eu vou voltar lá para falar para ela que eu acho que ela não estudou, para falar isso para você". A idéia de protestar contra a violência sofrida (que Edite não chega a levar adiante) não está, desse modo, mediada por nenhuma referência ao mundo dos direitos - não é à igualdade postulada pela cidadania que está na base do protesto de Edite, mas a igualdade humana; como a fala de Edite deixa transparecer, o respeito à diferença é uma questão de "esclarecimento" e é por isso que ela questiona a competência da selecionadora, despolitizando e privatizando a violência sofrida.
} 
e precisava a C.(...) E na semana em que eu comecei a tirar a carta, para o futuro, não que eu achei que...um ano, um ano e meio, eu imaginei que eles iam chamar, lá em Barueri mesmo. Mas logo chamaram, por telegrama, para mim comparecer lá com todos os documentos. Levei, até eu já tinha passado no psicotécnico, já, mas não aceitaram. Dali para cá eu decidi, sabe, eu vou prestar os concursos porque, já que em firma está difícil porque eu acho assim: concurso é mais fácil porque depende só de você estudar, depende só de você, né? (...) Então eu acho que o concurso, depende mais de você, né? E numa firma, não depende só de você, depende do ponto de vista com que o empregador te olha, não é verdade?"119.

Atualmente, mesmo estando empregada, Suely continua prestando concursos, enxergando neles a oportunidade de conseguir um emprego mais estável por seus próprios méritos, algo que ela também valoriza ${ }^{120}$.

Suely acredita, para as mulheres, a cobrança em relação à aparência é maior. Ao mesmo tempo, critica esse modo de selecionar e julgar as pessoas, pois em sua experiência observa que nem sempre as pessoas mais bonitinhas têm mais capacidade: "às vezes eu fico pensando, não sei por que as pessoas vêem assim, porque tem umas meninas que tem um corpinho tão bonito, são tão bonitas mas elas são tão vazias de idéias. Não sabe o que falar, não sabe conversar, nem escuta o que a pessoa fala, ela não entende o que a pessoa fala. Igual, no dia em que nós fomos fazer entrevista nesse mercado - e ela passou, chama Sueli também, é um amorzinho de pessoa, mas ela é meio burrinha, até hoje ela pergunta as coisas para mim; ela fala para mim "Suely", (e eu) "fala, Su", uma chama a

${ }^{119}$ A partir de maio de 2004, a Fundação para o Desenvolvimento do Estado - FUNDAP, atendendo a uma demanda da Casa Civil - Governo do Estado de São Paulo, ofereceu cursos de "Qualidade no Atendimento" para seus funcionários que trabalham com atendimento ao público, de modo geral funcionários com pouca escolaridade e que estão na "base" da hierarquia do funcionalismo. Professor de um dos módulos desse curso, após ter contato com cerca de 20 turmas, meu marido observou que o perfil dos funcionários: pouca escolaridade, muitas mulheres, muitos negros, pessoas mais velhas, pessoas obesas... Vários atributos pessoais que, num concurso público, têm chance de serem superados. Esse aspecto explica também a diferente composição do perfil dos trabalhadores, segundo atributos pessoais, no Distrito Federal (ver DIEESE, 1999, especialmente "As mulheres no mercado de trabalho" e "O trabalho da população negra").

${ }^{120}$ Durante o ano de 2003, muitas foram as reportagens (na imprensa escrita, noticiários televisivos e em programas especiais, como o Globo Repórter) que deram visibilidade ao número cada vez maior de pessoas que recorrem aos concursos como modo de conseguir um emprego. No Rio de Janeiro, um concurso para gari atraiu milhares de pessoas; em cidades pequenas, verdadeiras migrações acontecem quando vagas são abertas. As altas taxas de desemprego, sempre mobilizadas como fator explicativo, contribuem para entender o fenômeno mas não o explicam inteiramente. Nas falas das pessoas, transparecem outras questões além da dificuldade em encontrar emprego: o desejo de estabilidade e, também, a indistinção quanto a aspectos ligados à raça, cor ou religião, o que é visto como uma vantagem em relação à procura no setor privado. 
outra de Su - e eu lembro que no dia da entrevista, ele falou um negócio, uma coisa e ela não entendeu. E ela concordou, com tudo que ele disse. Aí ele chamou, ele falou em geral e depois foi chamando o pessoal para fazer entrevista, aí ela perguntou para mim "O que foi que ele falou mesmo, o que significa isso?", aí eu expliquei para ela e falei, "espera aí, porque é que você concordou? "Eu estou concordando com tudo", falei, "mas não é assim, você não entendeu que ele falou? "Eu não entendi quase nada do que ele falou". Então eu fico pensando, às vezes as pessoas são de bonitinhas, são assim, mas não têm muita...".

A tentativa de encontrar um emprego por meio dos concursos aparece, então, como uma maneira de se sentir segura quanto aos critérios utilizados na seleção. A fala de Suely revela, os outros critérios de empregabilidade que operam nas seleções - conhecidos por todos os trabalhadores, mas raramente explicitados: "Justamente, (porque no concurso) ali é preto no branco, você pode ser preta, você pode ser branca, você pode ser bonita, você pode ser feia, gorda, o que for. O que vale ali é a sua inteligência, o que você é capaz e no empregador não, ele vê tudo isso. Além de você ter escolaridade, ter que ter experiência, você tem que falar bem, você tem que ser bonita, você tem que ser branca - porque até hoje existe racismo e todo mundo sabe disso. Você não pode ser gorda, o que não é o meu caso..."121.

\section{A impossibilidade do descanso}

Durante as duas entrevistas que fiz com Suely, a questão da falta de tempo apareceu reiteradamente: "Olha, geralmente para eu descansar, só se eu dormir. Só se eu dormir (...) não tem outra coisa, porque ou eu estou assistindo o jornal, né? Ou eu estou lendo. Não tem outra coisa pra mim descansar. Ou eu pego e vou dar um pouquinho de atenção para o meu filho, o que é muito raro mesmo, só brinco com eles se eu estou em casa, fazendo o serviço e ele começa a conversar comigo, o bebê, né, e eu estou disponível, para conversar. Mas para descansar exatamente, nada, porque se meu filho está jogando vôlei lá

\footnotetext{
121 A percepção de Suely se ancora, é claro, em sua observação do que acontece, de fato, nos processos seletivos e também das notícias que circulam em jornais e jornais televisivos. Recentemente, uma pesquisa finlandesa apareceu nos noticiários, mostrando que mulheres obesas, em cargos executivos, recebiam em média 30\% menos do que mulheres magras (Estadão, 4/3/04). Também me recordo de ter visto (em 1999) algumas matérias em telejornais sobre mulheres americanas, com idade superior a 40 anos, que faziam plásticas como estratégia de reinserção no mercado de trabalho.
} 
fora, com ao amigos dele, e eu estou disponível, eu vou jogar vôlei. Então, para mim descansar, só se eu deitar e dormir, que outra coisa eu não faço".

Após a primeira entrevista, feita quando Suely estava desempregada, meu primeiro movimento foi compreender essa impossibilidade de descansar como uma forma de sublinhar a situação do desemprego aberto, ou seja, como um modo de reafirmar a continuidade da procura - ainda que ela mesma relatasse os períodos de cansaço e de interrupção.

Na segunda entrevista, no entanto, feita quando Suely havia conseguido um novo emprego, a impossibilidade de descanso continuava aparecendo, acentuada pela dupla jornada, fora e dentro de casa: "eu não leio mais; não tenho mais tempo. Nossa, o meu filho lê tanto, eu acho tão lindo, nossa, como ele lê: ele pega um livro, termina aquele livro, passa para outro. É tudo o que eu quero, poder ler um livro, mas eu não tenho tempo. Eu gosto de fazer bordado, crochê, eu não tenho mais tempo, porque, se eu estou fazendo isso hoje, para poder ser entrevistada por você, a roupa precisa ser lavada, eu não lavei - mas eu deixo para amanhã, amanhã eu não vou fazer nada, amanhã lavo a roupa. Mas se eu tivesse lavado a roupa hoje, com certeza amanhã teria uma outra coisa para eu fazer. Por exemplo, essa pia precisa ser limpa, dentro e fora, então eu preciso fazer. Então, todo dia tem coisa para mim fazer, não se preocupe, que descansar só na hora que eu deitar".

Nem o jornal, que na primeira entrevista, apareceu como uma necessidade para mantê-la informada, ela consegue assistir: "nem o jornal, ontem eu assisti o jornal passando roupa. Porque eu agora, eu trabalho muito com o corpo e fico muito cansada. Eu vou dormir dez horas, então eu quero deitar e dormir; eles querem assistir televisão e eu falo não...Eu falo para o Juliano, só se você levar a televisão lá para a cozinha e assistir, aqui não, no quarto não, eu quero...".

A sua "roça", que ela cultivava no tempo de desemprego, acabou sendo tomada pelo mato, na impossibilidade de continuar cuidando dela: "a minha rocinha está mato, virou mato, não tem mais nada (...) não dá tempo... mas mesmo assim, eu fico ali olhando, sabe, aonde que era...Na verdade ainda tem até mandioca plantada mas o mato cobriu porque eu não tenho tempo de limpar".

Contando sua rotina, desde quando acorda às seis da manhã, até quando volta para casa, às três da tarde, e depois a realização das tarefas domésticas, que geralmente a ocupam até às dez da noite, Suely deixa claro que não pára um instante. 
Em que pese sua própria personalidade, o fato é que essa constante movimentação é o tempo todo trazida à frente da cena na fala de Suely: ela revela uma ética que nada tem a ver com a atividade de trabalhar propriamente.

Trata-se de uma ética do trabalho relacionada à ocupação do tempo, mas, na trajetória de Suely, essa ocupação do tempo (de todos os tempos) e esse não descansar assumem o caráter de afirmação de sua capacidade de administrar sua própria vida, de lutar para a realização de seus sonhos - nos quais está incluída a obtenção de uma vida melhor para si e para os filhos. Ainda, também é um modo de não dar brechas à difamação, pois, como ela mesma disse, ninguém pode lhe cobrar nada, uma vez que trabalhando - fora ou dentro de casa - é em sua família que está pensando.

Na fala de Suely, é difícil distinguir os aspectos que se referem ao trabalho de outros aspectos de sua vida. Como ela mesma nota, a mulher que trabalha fora e dentro de casa só trabalha e ela não foge a esta sina.

Mas porque não distingue o trabalho fora e dentro de casa, Suely transita com facilidade entre diferentes situações ocupacionais: o desemprego ou a inatividade não põem em xeque sua identidade. Além disso, garantia de rendimentos mínimos advindos das pensões e dos aluguéis, possibilitam a ela alternar períodos de inatividade (como quando ficou só estudando), períodos de trabalho precário (os bicos, às vezes temporários, outros intermitentes, outros não registrados, mas em tudo o mais similares ao trabalho formal) e períodos de desemprego.

É no esforço para conquistar além do mínimo que a necessidade de trabalhar se inscreve para Suely. O trabalho aparece então como um imperativo - não da necessidade imediata da sobrevivência - mas do transpassamento dos limites e a conquista da autonomia: "eu acho assim, que quando a gente está trabalhando, a gente fica mais feliz, né? Não pensa em tantas besteiras. Por exemplo, se eu estou trabalhando, eu tenho que acordar, fazer meu serviço de casa e ir trabalhar. Trabalhando, além de trabalhar a gente conversa, está sempre aprendendo alguma coisa, sempre alguma coisa, por mais que seja uma rotina, mas é sempre alguma coisa que você está aprendendo, ainda mais no meu ramo de trabalho que é comércio, sempre está uma coisinha assim. E você se valoriza, se auto-valoriza "eu estou trabalhando, eu estou ganhando o meu dinheiro", né? E a gente está sempre 
aprendendo, sempre aprendendo, alguma coisa ou outra você aprende. Então eu acho que isso é diferente". 


\title{
CAPÍtulo 5 - POR FORA DOS TRILHOS: A LIDA DOS PRIMEIROS EMPREGOS
}

\begin{abstract}
"Você pode amar ou odiar o que aconteceu com o mercado de trabalho nos anos 90 e como isso afetou sua vida. Mas precisa fazer as pazes com o que passou. Nessa arena, assim como em outras, a postura é crucial, e todo empregador vai reparar nesse ponto. Você deve preparar sua cabeça para o mercado de trabalho de hoje sabendo que há quatro posturas fundamentais para se ter sucesso na caça ao emprego: 1)Todo emprego que você conseguir é temporário; 2)Todo emprego que você conseguir é, essencialmente, um aprendizado; 3) Todo emprego que você conseguir é, essencialmente, uma aventura e 4) Em todo emprego que conseguir, a sua satisfação deve ser conseguida no próprio trabalho", (Richard N. Bolles, "As cinco melhores maneiras de se conseguir um emprego").
\end{abstract}

Certa vez, enquanto esperava meu ônibus, um entregador de panfletos passou, distribuindo um pequeno anúncio, impresso em forma de carteira de trabalho, sobre uma escola de informática que oferecia diferentes cursos profissionalizantes: desde noções básicas de informática até aulas de marketing pessoal. Ao receber este panfleto, um senhor que estava sentado ao meu lado, e que já devia ter mais de sessenta anos, começou a comentar sua própria trajetória, refletindo sobre a proliferação de cursos como estes.

"Eu era atendente de farmácia”, disse ele, "e estudei toda a minha vida em escola pública. Naquela época, os filhinhos de papai iam para a escola particular, não porque lá fosse melhor, mas justamente porque lá era mais fraco e eles conseguiam passar de ano. Pois eu, atendente de balcão e entregador de remédios, entrei na Engenharia da USP. Quando estava no segundo ano, recebi uma bolsa de uma Fundação Alemã e com ela consegui comprar dois terrenos. Hoje, eu tenho algumas coisas. Mas a escola pública agora está tão ruim, que isso não é mais possível: quem hoje é motoboy vai continuar sendo"... 
Inicio este capítulo dedicado aos jovens em situação de desemprego oculto pelo desalento pela fala desse senhor porque esta revela, muito objetivamente, $a$ consciência da diminuição das possibilidades de mobilidade. A fala também revela a consciência de que as ocupações por meio das quais os jovens de baixa renda iniciavam sua vida profissional tinham significados bastante distintos em relação aos significados que assumem para a juventude atual. Em outras palavras: algo mudou e não apenas as pessoas mais velhas percebem as mudanças quando contrastam as experiências dos jovens com as suas próprias; também os jovens percebem que o mundo do trabalho para o qual foram socializados não existe mais.

Analisar as narrativas dos jovens que entrevistei não foi uma tarefa simples: desde o primeiro esforço de aproximação com o conjunto de entrevistas, as falas dos jovens me causavam muito estranhamento; eu os acusava de "laconismo" e suas representações sobre trabalho e emprego, de tão imbricadas aos discursos que circulam nas diversas mídias, pareciam-me inacessíveis ${ }^{122}$. As entrevistas realizadas com jovens, e o universo que revelam, são bastante distintas das narrativas dos adultos e provocam um outro conjunto de reflexões que eu, limitada pelo tempo e pelo escopo de uma pesquisa de mestrado não poderia de modo algum desenvolver com a profundidade que o tema exige. As reflexões expostas neste capítulo, assim, devem ser entendidas como esforço de compreender as experiências narradas pelos jovens a partir do problema proposto pela pesquisa, sem no entanto chegar à qualquer compreensão mais geral sobre o problema da juventude e do trabalho (mesmo porque tal universo é tão heterogêneo que qualquer tentativa de generalização

\footnotetext{
122 Sobre essa descrição da sensação de que os entrevistados mais lacônicos que encontrei tinham em comum o fato de serem jovens, a professora Nadya Guimarães, durante o exame de qualificação, apontou diversos momentos de meu texto nos quais tal descrição se mostrava incompatível com a experiência do trabalho de campo. O desencontro apontado por ela foi bastante inquietante e me fez olhar com mais cuidado para as entrevistas, procurando chegar a uma problematização sociológica da minha dificuldade em ouvir o que eles estavam a me dizer.
} 
teria que lidar com a impossibilidade de afirmar "a juventude de hoje é" ou "as questões enfrentadas pela juventude são"123).

Talvez as dificuldades que enfrentei se devam ao fato de que, quando formulei inicialmente meu problema sociológico, não considerei a possibilidade de encontro com jovens, especificamente. Imaginei que teria como principais informantes pessoas adultas, principalmente do sexo masculino, que fossem portadoras de uma identidade de trabalho já constituída. Tal hipótese decorria da maneira pela qual havia formulado meu problema: interessava-me principalmente compreender os deslocamentos no imaginário do emprego e do trabalho e, nesse sentido, pensava que tomar pessoas com trajetórias de trabalho iniciadas num momento em que existiam empregos - senão de fato, ao menos como horizonte plausível - contribuiria para lançar algumas luzes sobre as mudanças em curso ${ }^{124}$.

$\mathrm{Na}$ medida em que a pesquisa se desenvolvia, no entanto, os limites do modo original de formular o problema foram se evidenciando: do ponto de vista das medidas de desemprego, o desemprego oculto por desalento punha em cena principalmente o desemprego feminino; do ponto de vista do trabalho de campo, encontrei muitos jovens e mulheres em situação de desemprego oculto pelo desalento; do ponto de vista analítico, os jovens, assim como as mulheres, emergiram em diferentes discursos, mostrando que sua presença no mercado de trabalho podia ser considerada como um eixo de problematização por meio da referência aos jovens e à sua relação com o trabalho, muitos adultos

\footnotetext{
123 No universo das questões levantadas por uma "sociologia da juventude" (ou uma "sociologia da transição"), tem aparecido diversas reflexões que põem em dúvida a univocidade do conceito de "juventude", não apenas no que se refere a considerá-la como um intervalo etariamente definido, cujo objetivo seria a transição para a vida adulta, mas também no que se refere ao reconhecimento de que não há apenas uma juventude, mas várias, o que leva alguns autores a afirmar que o que existe, de fato, são "os jovens", irredutíveis a idéia geral de juventude. Para uma discussão bastante seminal sobre os significados possíveis da heterogeneidade, ver Singly (2000) e Schehr (2000). Para uma discussão sobre a arbitrariedade da construção das faixas etárias que definem quem é ou não jovem, ver Gauthier (2000).

124 Considero esse "momento" como o período que vai do início da década de 70 até meados dos anos 80, tendo em conta as taxas de crescimento econômico do período - média de 8,82 ao ano, conforme dados do IPEA (www.ipeadata.gov.br) - que, naquela conjuntura, implicavam também em geração de novos postos de trabalho.
} 
e até mesmo os próprios jovens trouxeram à tona os valores e os modos de vida que as transformações põem em questão.

O desalento dos jovens então, descoberto durante o trabalho de campo, é o tema deste capítulo não apenas porque os jovens “apareceram", em carne e osso, mas também porque apareceram diversas vezes nas falas e representações dos adultos. Suas histórias, seus projetos de carreira profissional, suas possibilidades de realizá-los, fornecem, em si mesmos, elementos de reflexão que ajudam a pensar o momento presente. Eles constroem seus projetos e representações à diferença das trajetórias de seus pais, chefes ou professores, e, assim, dão visibilidade a conflitos que estão no centro das indefinições relativas ao trabalho ${ }^{125}$.

Como já apontei anteriormente, a primeira impressão que as entrevistas realizadas com os jovens deixaram em mim foi de "laconismo": em relação aos adultos, as entrevistas não fluíam com a mesma facilidade; eu tinha que ficar o tempo todo fazendo e refazendo perguntas e eles geralmente respondiam apenas o perguntado, em seguida ficando silenciosos, a esperar outras questões.

No momento de redação da dissertação, e de seleção das histórias a serem analisadas, foi que a primeira atribuição aos jovens de um certo "laconismo" começou a ganhar outro sentido e foi possível perceber, então, que ela apontava para a minha dificuldade em transpassar os discursos que eles traziam, quase sempre bastante parecidos entre si (a despeito de suas distintas trajetórias). As falas dos jovens dão notícia de vários aspectos das mudanças no mundo do trabalho pois que, sem ter vivido uma experiência de trabalho, seu discurso tem como horizonte projetos profissionais e, desse modo, estão mediados (e em

\footnotetext{
${ }^{125}$ Não à toa, no que se refere às atitudes em relação ao trabalho, os conflitos entre adultos e jovens aparecem de modo bastante claro. Como notam Gauthier e Singly (2000), o lugar ocupado pela inserção no mundo do trabalho, quando se concebia a juventude como uma série de etapas de transição ao mundo adulto, era central: tratava-se do auge da integração. Desse modo, o deslocamento das formas de inserção/integração acaba por se apresentar como eixo importante de problematização sobre as conseqüências das mudanças na organização do mundo do trabalho pois reflete não apenas sobre a vida dos jovens, mas reorganiza as relações entre gerações e obriga a reconsiderar as trajetórias tidas como "normais". Ver também Dubar (????).
} 
muitos casos, limitados) pelas figuras e representações dos novos padrões de empregabilidade ${ }^{126}$.

Seu desemprego, e seu desalento, são nesse sentido, fundamentalmente diferentes, não apenas por sua específica inscrição social - de jovens - mas porque as figurações que possuem como instrumento de compreensão estão informadas pelas representações que circulam na sociedade, (quase sempre) sem a ponderação de uma experiência concreta de trabalho. Enquanto os adultos deixam de procurar por paralisarem frente às novas formas de procurar emprego (José), por chegarem à conclusão de que não vale mais a pena (Fátima) ou por cansaço (Suely), os jovens (melhor dizendo, os jovens entrevistados) deixam de procurar desmotivados pela constante frustração de seus projetos: demonstram participar da idéia de que o início da atividade profissional representa o caminho de transição para a vida adulta e também de que se trata de um passo decisivo para a construção e manutenção de seus atributos de empregabilidade. Sabem que estarão fadados a uma vida de constante movimento, mas não conseguem nem mesmo dar esse primeiro passo. Por essa razão, o desalento entre eles aparece sob a forma ou do cansaço e da tristeza ou da raiva e da indignação.

Em razão das histórias de trabalho dos jovens serem bastante diversas das trajetórias dos adultos, o critério que orientou a escolha das narrativas a serem analisadas foi diferente e aqui apresento a história de quatro jovens - os quatro que encontrei em situação de desemprego oculto pelo desalento ${ }^{127}$. Suas

\footnotetext{
126 A questão da empregabilidade emergiu como um dos temas centrais para a compreensão das narrativas dos jovens pois, para explicar suas dificuldades em encontrar um trabalho, analisavam sua situação da perspectiva do "mercado de trabalho" ou do "empregador": assim, era com muita clareza que reconheciam os aspectos que os tornavam mais vulneráveis - desde a pouca escolaridade, a falta de experiência ou a aparência até a qualidade dos bens culturais aos quais têm acesso. Para uma reflexão sobre os usos do termo empregabilidade, ver Castro, Cardoso e Caruso (1997), Leite (1997) e Martins (2004).

127 A rigor, havia mais um jovem que poderia ser considerado como tendo experimentado a situação de desalento: Marcel (entrevistado em dezembro de 2003) tem 18 anos, procurava desde o início de 2002 (quando estava no segundo ano do ensino médio) e relatou sempre interromper a procura durante o período de provas; nunca trabalhou e não tem uma idéia muito clara do que vai fazer, apenas que será na área de saúde. Deixei-o de fora desse capítulo, no entanto, porque sua primeira entrevista foi bastante curta, sem que houvesse elementos suficientes para descrição de sua experiência. Ademais, quando o procurei para realizar uma
} 
experiências, heterogêneas entre si, lançam luz sobre alguns temas importantes, permitindo compreendê-las tendo como referência as mudanças ocorridas no mundo do trabalho. Por outro lado, existem alguns pontos comuns em suas falas, que contribuem para nos dar uma idéia das representações mais gerais que circulam e são incorporadas ao discursos desses jovens, sem distinção quanto à sua experiência pessoal.

Há ainda outra diferença em relação à maneira de tratar a história dos adultos: algumas entrevistas feitas com jovens, por sua longa duração e pela profundidade com que os temas apareceram, forneceram material suficiente para as análises aqui apresentadas e é por esta razão que, ao contrário dos "adultos", cujas trajetórias mais longas exigiam a realização de uma nova entrevista para complementação das informações, optei por não entrevistar novamente estes jovens. Tal decisão foi tomada também tendo em conta as falas encontradas na literatura preocupada em refletir especificamente sobre as relações da juventude com o trabalho: mesmo em pesquisas de mais fôlego, apoiadas na realização de entrevistas mais longas, o caráter geral dos discursos não é diferente ${ }^{128}$. Desse modo, as possíveis contribuições que essa pesquisa teria a dar à compreensão do problema não residiria tanto na originalidade das falas colhidas durante as entrevistas, mas na maneira de interpretá-las, relacionando-as ao quadro geral que compõem as preocupações que me propus a enfrentar.

Mas antes de tecer hipóteses ou explicitar conclusões, é preciso examinar com mais cuidado as histórias desses jovens. Passemos, então, a isso.

entrevista mais longa, ele não pareceu entender muito bem o sentido de eu procurá-lo, propondo-me que o encontrasse num supermercado aonde ele encontraria os amigos. É importante observar, ainda, que entrevistei, ao todo, nove jovens - com idades entre 17 e 24 anos - dos quais, um era ocupado, três estavam em desemprego aberto e cinco tinha experimentado o desemprego oculto por desalento.

128 Ver, por exemplo, Gomes (1997), Bajoit e Franssen (1997), Singly (1997), Pais (2001), Souza (2003) e Martins (2004). 


\section{I - Entre a sorte e o merecimento - Mário}

Mário tem 18 anos, é solteiro e mora com os pais; tem quatro irmãos. Seu pai tem times de rúgbi e futebol e também é assessor de políticos; sua mãe é dona-de-casa, por exigência do pai - "minha mãe não (trabalha). Também não precisa, meu pai fala: mulher fica dentro de casa". Mário procura emprego desde os 16 anos e, no momento da entrevista, estava no último ano do ensino médio. Branco, alto, magro e falante, a entrevista que fiz com ele, em outubro de 2002, durou quase cinqüenta minutos. E ainda que, diversas vezes, ao fim de suas respostas, ele se virasse para mim, mal suportando alguns segundos de silêncio, e me dissesse, "Vai, outra pergunta", em outros momentos ele encadeava uma seqüência de lembranças, argumentos e seguia dizendo e descrevendo a sua experiência de desemprego, sem que eu precisasse intervir.

Mário estava à procura de seu primeiro emprego, mas isso não significa que nunca tivesse trabalhado. Ele trabalhou durante um período com o pai, mas desqualifica esta experiência à medida em que constata que ela não o ajuda a encontrar um emprego - "eu tenho experiência com meu pai, mas não adianta experiência com o pai, o mercado não reconhece isso como experiência"; e depois, após a realização de alguns cursos, estagiou por curtos períodos, tendo três meses de experiência em telemarketing ${ }^{129}$.

O comportamento irrequieto de Mário transparece em sua experiência de procura de trabalho: ao longo do ensino médio (que seria concluído ao final de 2002), ele relatou ter feito mais de dez cursos. Apesar de se tratar do seu primeiro emprego, Mário não procurava aleatoriamente; tinha em vista um setor bastante específico do mercado de trabalho, qual seja, a área gráfica. A

\footnotetext{
129 Como noticiou a revista Veja, os jovens constituem a maioria de trabalhadores empregados em telemarketing: $45 \%$ dos atendentes estão em seu primeiro emprego; dentre esses jovens, há uma predominância feminina. A rotatividade no ramo é grande, o trabalho é estressante e o segmento do setor que mais se expande - aquele que presta serviços para empresas internacionais, prolifera justamente na esteira do esforço dessas empresas para reduzir seus custos (um atendente brasileiro ganha cerca de um terço do que seu colega americano, o que tem rendido protestos dos sindicatos norte-americanos); ainda assim, trata-se de uma porta significativa de entrada no mundo do trabalho (Veja, 12/02/2004).
} 
cada curso feito, suas expectativas de conseguir um trabalho aumentavam, e ele deixou claro sua preferência por um trabalho bem remunerado, que possibilite a ele fazer uma faculdade de design gráfico e que lhe ofereça chances de crescimento e aprendizagem.

O período de desemprego por desalento experimentado por Mário se deveu ao desânimo diante da frustração das buscas e também pela observação da situação de amigos e do irmão, que conseguem trabalho mais facilmente que ele, sem tanto esforço. Segundo me relatou, essa situação é "de deixar qualquer um com raiva" e por isso ele interrompeu suas buscas por um tempo. A necessidade de trabalhar, no entanto, o impulsionou de volta ao mercado de trabalho.

Alguns aspectos chamam a atenção no relato de Mário. O primeiro deles se refere ao comportamento contínuo de acúmulo de qualificação - ao mesmo tempo que procura um trabalho e que reconhece que começar a trabalhar é fundamental para a construção de sua empregabilidade, Mário continua realizando cursos e mais cursos, muitas vezes mesmo sem ter as condições financeiras para fazê-lo ${ }^{130}$. Sua constante inquietação, que em um certo sentido se aproxima à "correria" característica das pessoas que estão em situação de desemprego aberto, possui, ao mesmo tempo, outro caráter, pois que é reveladora de sua consciência de que, atualmente, nada nunca é suficiente. Ao contrário . O mercado de trabalho, assim, na visão de Mário, é exigente e impossível de ser satisfeito e a única saída que lhe resta é procurar acompanhar o ritmo.

Outro aspecto importante se refere à recusa ao trabalho pesado, nãoqualificado, "braçal", expressa por Mário principalmente quando analisa o comportamento e os sonhos de seus colegas e amigos. Mário diz, reiteradamente, que quer outra coisa, algo que corresponda às suas capacidades e ao seu esforço.

\footnotetext{
${ }^{130} \mathrm{Na}$ ocasião da entrevista, por exemplo, uma amiga estava lhe emprestando o dinheiro para o transporte, permitindo que ele continuasse a fazer mais um curso da área gráfica na Fundação Bradesco.
} 
Terceiro aspecto importante, o relato de Mário dá noticia dos conflitos existentes entre duas gerações de trabalhadores, a dele e a de seus pais. Finalmente, a trajetória de Mário ajuda a pensar sobre a construção do merecimento, tão ou mais importante do que a empregabilidade e freqüentemente, nas falas, com ela confundida. Em sua trajetória, o desalento assume menos o caráter de expressão de um desânimo frente à dificuldade de encontrar um trabalho (embora tal aspecto esteja presente) e mais a forma da raiva e da inconformação.

A procura pelo emprego: o que se quer e o que se pode - Logo no início da entrevista, Mário declarou estar procurando emprego desde os dezesseis anos; para checar a informação, perguntei novamente, "você está procurando emprego, então, há dois anos, desde os dezesseis..." e ele começou a rir. Perguntei por que ele ria e ele respondeu: "(desde os) 16, praticamente é a minha vida!". Essa fala é reveladora da impaciência de Mário, que parece bastante consciente de que cada momento vivido fora do mercado de trabalho conta, sendo necessário se inserir o quanto antes a fim de garantir uma trajetória nos moldes sonhados por ele.

A problematização de sua juventude e da marca que esta imprime à experiência de procurar o primeiro emprego aparece todo o tempo nas falas de Mário: "Estou há muito tempo procurando, já cansei de procurar em Alphaville, nesses lugares... Mas, sinceramente eu já desanimei porque quando procura assim, a pessoa já pede experiência ou o grau de escolaridade - que eu não terminei o terceiro ano - eles não dão assim aquela oportunidade. Já consegui emprego e chega lá, e ganha pouco por causa da escolaridade (que eu não terminei ensino médio), ou por causa da idade: a maior parte das vagas que estão oferecendo aí é acima de 21 anos, eu não tenho isso. Ou se você tem 18 anos, tem que ter três meses de experiência, então...". O que há de interessante nessa fala é que a idade, reconhecida como um atributo que o torna mais ou menos empregável e que tem conseqüências para a qualidade do trabalho à sua disposição, aparece como se fosse algo que estivesse sob seu poder controlar, tal como a escolaridade ou a qualificação - "eu não tenho isso", expressa, desse 
modo, a frustração em não conseguir corresponder às exigências do mercado de trabalho nem naquilo que é mais natural. O tom utilizado por Mário ao dizer isso é o mesmo que usa em outros momentos da entrevista, quando fala das barreiras que encontra para começar a trabalhar: constantemente, ele enfrenta os limites de não conseguir mostrar quem é, mostrar o que sabe, mostrar sua capacidade de trabalhar ${ }^{131}$. Não à toa, o que estrutura a explicação sobre o seu desânimo, são as faltas que ele percebe em si mesmo e que ele procura superar por meio de um comportamento diligente. A dificuldade para encontrar esse primeiro emprego se constitui, desse modo, numa barreira que complica a concretização de todos os sonhos e expectativas que Mário alimenta.

Mário não se considera um desempregado, mas alguém à procura de emprego. Para ele, a condição de desempregado tem a ver com a experiência anterior de um emprego: "desempregado é aquele que teve um emprego e não conseguiu ficar nele ou porque a empresa faliu ou porque ele não tinha capacidade mesmo, hoje em dia a maior parte é isso: a pessoa, ela entra numa empresa se acomoda e não cresce. Aí o empregador vê que o carinha não está interessado e fala "Ah, vamos deixar ele aqui para quê? Ele não mostra nenhum empenho, não faz, não estuda, não faz porcaria nenhuma e então a gente não deixa". Então, a pessoa perde o emprego por bobagem e, como a gente fala, emprego é muito difícil, você tem que encontrar serviço, hoje em dia é temporário, qualquer coisa". Essa distinção que Mário faz entre quem procura o primeiro emprego e quem está desempregado é muito importante do ponto de vista analítico. Trata-se de uma distinção operada a partir de alguns critérios a respeito do "trabalhador ideal", revelando valores e práticas com as quais Mário demonstra ter uma relação de identidade. Mesmo que ainda não tenha tido a experiência de ter um emprego, Mário demonstra aqui sua participação no universo do trabalho, ao compartilhar de alguns valores que dele fazem parte e ao estruturar sua identidade em contraposição ao trabalhador acomodado ao emprego: essa participação é fundamental para a compreensão do comportamento de acúmulo de cursos. Diferentemente dos

\footnotetext{
131 Uma interessante discussão sobre os critérios utilizados pelas empresas, para a contratação de funcionários jovens, pode ser encontrada em Madeira (1993) e Gomes (1997).
} 
trabalhadores mais velhos, desempregados, que "correm" para fugir ao estigma da vadiagem, Mário "corre" para afirmar seu perfil de "trabalhador ideal”, que não se acomoda e que busca a auto-realização nas atividades desempenhadas ${ }^{132}$. Ainda que reconheça a existência do desemprego involuntário - por falência da empresa, por exemplo - ele diz que na maioria dos casos o desemprego se deve ao próprio trabalhador, desinteressado e acomodado na situação de ter um emprego.

Essa maneira de pensar o desemprego, atribuindo grande parte da responsabilidade ao comportamento do próprio trabalhador é bastante comum $^{133}$. No caso dos trabalhadores egressos do mercado de trabalho, porém, essa maneira de pensar toma a forma da auto-responsabilização, pois reavaliam sua trajetória e suas práticas a partir da situação presente e chegam à conclusão de que têm culpa pela situação que vivem hoje. No caso de Mário, essa forma de pensar é constitutiva da identidade de trabalhador que ele se empenha em construir para si: a não acomodação, a vontade de crescer dentro da empresa, a disposição para constantemente fazer cursos, todas estas são qualidades que reconhece em si mesmo, tornando-se assim merecedor de uma oportunidade para mostrar quem é, e o que pode fazer.

Há mais um aspecto importante na fala de Mário, pois ele já distingue aqui emprego e trabalho. Emprego, diz ele, é algo cada vez mais difícil de ser conseguido; o que aparece - quando aparece - são os trabalhos temporários, contratados por um período determinado de tempo. Desse modo, a escassez de empregos, no argumento de Mário, reforça a necessidade de se manter em

\footnotetext{
132 Alguns estudos, que procuram questionar a idéia de que os jovens sofreriam de uma "alergia ao trabalho", sugerem que menos do que recusar o trabalho, tais jovens recusam o trabalho esvaziado de sentido (Bajoit e Franssen, 1997, Chiesi e Martinelli, 1997 e Schehr, 2000). Outro deslocamento importante se refere aos eixos por onde se estruturam os sentidos com os quais se avalia o trabalho: realização pessoal, aprendizado constante, possibilidade de crescimento (tanto do ponto de vista pessoal quanto do ponto de vista da carreira), qualidade do ambiente de trabalho (avaliada a partir do tipo de sociabilidade estabelecida), enfim, trata-se da valorização de aspectos que se afastam bastante da idéia de dignidade, autonomia e provisão das necessidades familiares que parecia mediar a relação dos adultos com o trabalho (os aspectos que informavam as atitudes em relação ao trabalho foram bastante explorados a partir das narrativas dos adultos, nos capítulos 3 e 4).

${ }^{133}$ Conforme Capítulo 2 e a análise da trajetória de Suely e de José já demonstraram.
} 
movimento, no esforço de acompanhar as exigências do mercado de trabalho, e informa sua impaciência.

Ele retoma tal distinção em outro momento da entrevista: "Mas emprego é uma coisa que a pessoa mais deseja; tem muita gente que está procurando emprego? Não, tem mais pessoas que estão procurando trabalho. Porque às vezes, muitos dos meus amigos não tem nada o que fazer, o que eles arrumam de bico é trabalho, porque eles não se animam na noção necessária para um cargo para valer. Já num emprego você recebe aquilo que vale a pena". A diferença entre emprego e trabalho aparece aqui de modo mais evidente. Tratam-se, realmente, de duas formas de se inserir no mercado de trabalho e Mário localiza na raiz da diferença o gosto e o empenho em relação à atividade profissional. As atividades realizadas apenas no intuito de ganhar dinheiro são consideradas trabalho. Aquelas realizadas na área de escolha do trabalhador, a qual este dedicou tempo de estudo e empenho, são consideradas emprego e é por isso que até a remuneração é diferente: nesse caso, o trabalhador possui um valor, que lhe permite cobrar o que é justo.

A partir de entrevistas realizadas com jovens belgas, Bajoit e Franssen destacaram pelo menos dois tipos de comportamento em relação ao trabalho: um, geralmente mais característico de jovens de baixa renda e pouca escolaridade, que tendiam a instrumentalizar a relação com o trabalho, projetando toda a esperança de realização em outras esferas da vida, tais como a família ou algum hobby; o outro tipo de comportamento, este geralmente mais presente em jovens de classes médias, com acesso à escolarização, consistia em valorizar o trabalho como uma esfera de invenção e experimentação, projetando nela as esperanças de auto-realização (Bajoit e Franssen, 1997).

Nas entrevistas que realizou no âmbito de sua pesquisa de doutorado, Suzanna Sochaczewski encontrou diferenças importantes entre os jovens, segundo fossem "herdeiros" (filhos de operários) ou "recém-chegados" (jovens que trabalhavam há pouco tempo na indústria e cuja trajetória, antes disso, fora caracterizada por intermitências, alta rotatividade e trabalhos precários). Enquanto os primeiros pareciam portar uma identidade profissional mais 
definida, os segundos evidenciavam uma relação mais utilitarista em relação ao emprego; outro dado interessante é o de que, enquanto os "herdeiros" pareciam bastante conscientes da instabilidade que caracterizava suas posições, os "recém-chegados" demonstravam crer que uma atitude de aumento da escolaridade e acúmulo de cursos de qualificação poderiam ser suficientes para mantê-los no mesmo emprego ou, em caso de demissão, assegurar o acesso a outro posto. Ambos os "tipos" de jovens, no entanto, mediam o valor do trabalho desempenhado segundo os ganhos gerados por ele (Sochaczewski, 1998).

Chamo a atenção para esses aspectos porque, de alguma maneira, a questão da identidade profissional aparece muito fortemente na narrativa de Mário: ele conhece a realidade do mercado de trabalho - conhece as barreiras e os limites que estão dados por seu ponto de origem - mas ainda assim (ou por isso mesmo) mantém a esperança em obter um emprego pois reconhece que uma vez que é menos descontínuo do que os bicos - esta é a condição tanto para que possa aprender um ofício quanto para que possa ter alguma chance de acompanhar a rápida evolução do setor gráfico. É esse aprendizado que vai conferir valor ao seu trabalho, que vai distingui-lo.

O trabalho, nessa visão, está ligado essencialmente à sobrevivência; já o emprego se liga a um projeto de vida - e aparece relacionado a um trabalho que têm sentido 134 . Mário recusa o trabalho "pesado" que gastaria suas forças e possibilidades de desenvolvimento pessoal, mas se mostra muito disposto a desempenhar atividades prazerosas, nas quais há aprendizado. Assim, não há qualquer sinal de uma "alergia ao trabalho". O que há é a recusa ao estabelecimento de um compromisso com o trabalho que não parece ter sentido. Há aqui um deslocamento fundamental: o que confere sentido ao trabalho permitindo que se possa compreendê-lo como uma atividade necessária à sobrevivência ou como um parte de um projeto de vida - é o caráter do próprio trabalho e é apoiado nessa distinção que Mário vai expressar sua preferência

134 Cf. nota 131. 
por um emprego pois, como destaquei acima, o que lhe interessa é a constituição de uma identidade profissional.

Para Mário, o fator mais importante para se conseguir um emprego está relacionado à rede de relacionamentos da qual se dispõe. A despeito das exigências do mercado de trabalho, ele reconhece que a possibilidade de inserção depende de uma rede de contatos, o que coloca uma importante tensão na forma de compreender o funcionamento do mundo do trabalho pois além de preencher todos os requisitos, é preciso conhecer as pessoas "certas".

É então, no esforço de superar a falta de contatos, que surgem estratégias tais como a mentira - "Hoje em dia o mercado de trabalho é muito competitivo, que nem eu falo: o mundo é dos espertos. Hoje em dia, uma pessoa não entra em algum lugar se não tiver alguém lá dentro, (...) em agência, normalmente, eu tento, às vezes eu até minto o meu currículo - falo que tenho experiência; chego até a passar... Eu falo, eu tenho muito mais capacidade do que muitos que têm experiência mas não adianta mostrar que a gente tem capacidade, a gente tem que provar".

É importante sublinhar, no entanto, que a mentira não tem por objetivo "enganar", mas estrategicamente fazer desaparecer uma barreira construída sobre pressupostos destituídos de sentido ou legitimidade (ao menos na percepção do desempregado) ${ }^{135}$. Com a mentira, aumenta-se a chance de ter uma oportunidade de mostrar o próprio trabalho e a crença de que, após a demonstração de que se é capaz o próprio empregador será levado a reconhecer a falta de sentido da regra, reforça a hipótese de que a mentira não é contada de má-fé. Antes, ela revela o conhecimento do modo de funcionamento do mercado de trabalho, a crítica que se faz a ele e também o reconhecimento do escopo de estratégias que se encontram ao alcance do trabalhador - incapaz de modificar a ordem das coisas, modifica a postura que se espera dele.

Mário se inscreve em vários estágios, procura emprego pela internet ${ }^{136}$, além de bater muita perna. No entanto, ainda não conseguiu nada e repetiu

\footnotetext{
${ }^{135}$ A mentira como estratégia de superação dos atributos que são percebidos como fatores que dificultam a entrada no mercado de trabalho também apareceu na fala de Suely (capítulo 4).

${ }^{136}$ A internet aparece como a principal ferramenta de procura de jovens com acesso a ela, tanto para envio de currículos quanto para pesquisa de vagas. Esse modo de procurar contrasta
} 
diversas vezes durante a entrevista que era injusto que encontrar um emprego dependesse de sorte. Ilustrando tal injustiça, observou que alguns amigos mal começavam a procurar emprego e já encontravam, enquanto ele não conseguia nada. Aliás, a entrevista começou com o relato de um caso que confirmava a injustiça e a pouca lógica que Mário atribui ao funcionamento do mercado de trabalho: "Eu vejo lá em casa, tem pessoas que nascem sortudas porque meu irmão, que nunca procurou emprego na vida - tem 17 anos - só vivia deitado, eu fiz a ficha dele no CIEE, vai e chamam ele para fazer um estágio. Nunca foi uma vez lá no CIEE, em Alphaville, nunca foi fazer a ficha, nunca deu currículo. E ele consegue um emprego? Isso deixa qualquer um com raiva, eu já...Eu fiquei cansado mesmo (...)eu preenchi para ele (para o irmão) na internet no CIEE, sem querer ainda eu errei a data de nascimento dele, e ele foi chamado - nunca tinha ido no CIEE, nunca pegou aquela fila, nunca ficou horas lá esperando... Ele foi lá, pegou, foi encaminhado, o único trabalho que ele teve foi ir a empresa, voltar, voltar com papel. E ainda ele arrumou tudo que ele tinha que fazer".

A evidente injustiça, que premia aqueles que não se esforçam e ignora o empenho daqueles que adotam um comportamento mais adequado ao que circula como conjunto de "exigências" atuais, é um fator de cansaço para Mário. Fica difícil persistir procurando - resistindo às pressões familiares, à falta de resposta das agências e ao testemunho de outras pessoas que encontram trabalho sem tanto esforço como ele. Mário insiste na procura, porém: “Uma, por necessidade mesmo, porque a situação na minha casa está difícil e eu também quero ver se eu consigo trabalhar para fazer os meus cursos. Por que tem cursos todos os dias, principalmente na área gráfica...".

fortemente com as estratégias utilizadas pelos adultos. Podemos tomar a fala de José como exemplo - ele limita sua procura ao Centro de Solidariedade por não saber como lidar com a procura em agências; sua forma de procurar busca garantir uma certa "pessoalidade", senão nos critérios para contratação, ao menos no atendimento. Os jovens, por sua vez, vêem a impessoalidade do processo via internet como algo normal, até mesmo desejável, pois em princípio o critério que opera nesse tipo de seleção é mais objetivo e recompensa melhor as competências individuais. Vale notar, entre os adultos, encontrei apenas um homem que declarou procurar por meio da internet - Éder, (45 anos, desempregado há 1 ano e 1 mês e em situação de desemprego aberto), que é projetista e tem no computador um importante instrumento de trabalho. 
A necessidade de trabalhar está informada, desse modo, por outras duas necessidades: ajudar em casa e construir empregabilidade, atualizando-se em cursos e acompanhando as novidades do mercado de trabalho.

Quanto a ajudar em casa, é interessante notar que não aparece no horizonte de desejos ou possibilidades deixar a casa dos pais: Mário não exprime, assim, o desejo de se tornar independente dos pais, mas sim de poder oferecer algo em troca dos sacrifícios que eles fizeram para permitir que ele permanecesse na escola e chegasse aos 18 anos sem ter a necessidade de trabalhar, deixando assim de se sentir devedor. Aliás, é preciso lembrar que, em diferentes momentos da entrevista, a tensão entre ele e o padrasto, que ao mesmo tempo que lhe ajuda, depois "joga na cara", apareceu como impulso para o início do trabalho e da contribuição com as despesas da casa ou, pelo menos, pela assunção da responsabilidade pelas suas próprias despesas ${ }^{137}$.

François de Singly (2000) traz uma interessante reflexão sobre nossa perplexidade em relação às novas realidades enfrentadas pela juventude, uma vez que - até há pouco - ser "adulto" significava conquistar, conjuntamente, autonomia e independência (estes aparecia, portanto, como os dois eixos principais do processo de individualização). À medida que as etapas de transição para a vida adulta se borram, porém, é possível dissociar tais conquistas e, assim, temse a situação de jovens adultos, autônomos (ou seja, capazes de tomar suas próprias decisões) ainda que não sejam independentes (ou seja, ainda que não sejam capazes de assegurar estavelmente sua sobrevivência). A experiência dessa dissociação tem importantes efeitos sobre a auto-representação de tais jovens e também sobre as relações inter-geracionais - um exemplo bastante visível é o conflito relatado por Mário, tanto em relação à sua mãe quanto em relação a seu padrasto. O reconhecimento de tais perplexidades é um passo

\footnotetext{
${ }^{137}$ Maria Inês Caetano mostrou que, a despeito dos sacrifícios feitos pelas famílias para permitir que os filhos permaneçam na escola sem que a necessidade de trabalhar os empurre para o mercado de trabalho, muitas vezes a vontade de consumir dos jovens acaba fazendo com que comecem a trabalhar (ou a procurar emprego) para garantir a compra de suas coisas. Os rendimentos do trabalho, então, não são considerados como complementares à renda familiar, mas sim como uma forma de assegurar uma certa autonomia em relação aos pais, (Caetano, 2004, especialmente Capítulo 6, "As curtas trajetórias dos jovens e a multiplicidade nas relações com o mundo").
} 
necessário para a compreensão dos vários aspectos levantados pelas narrativas dos jovens aqui apresentadas.

Mário se sente ainda mais responsável porque é um dos filhos que mais dá despesas (principalmente com deslocamentos para seus cursos e com a conta telefônica, já que usa bastante a internet): "Só que é, que nem aquele negócio, quando apareceu esse emprego a minha mãe queria muito que eu tivesse pego porque o meu irmão é mão-de-vaca. Ele não quer bancar nada em casa, gastar em nada. Eu que dou mais gastos em casa, não tenho". Esse sentimento de responsabilidade será analisado mais à frente.

Quanto à garantir sua empregabilidade, Mário oscila entre achar-se qualificado e capaz de assumir um trabalho na área gráfica e a compreensão de que o ensino médio não lhe ensinou nada "útil" e que é preciso começar a trabalhar para aprender a trabalhar: "Eu, é o meu primeiro emprego, eu não posso falar nada! Como é o meu primeiro emprego, eu não tenho experiência em nada (...). Então, eu vou te falar: minha qualificação não cola com que eu sei fazer, cuja profissão é a única que eu aprendo durante os cursos, já tenho dez cursos e... sabe, nada eu consegui. Só telemarketing, nem isso direito, pede seis meses de experiência e eu tenho três; não dá!".

A evidente confusão de termos e referenciais presentes nessa fala deixa clara a indistinção de valores e regras que os jovens estão enfrentando ao entrar no mercado de trabalho: Mário fala em experiência (que ele não tem) e em qualificação e profissão (termos que seu discurso torna idênticos). Ao mesmo tempo que sugere que a falta de experiência dificulta seu posicionamento em relação à compreensão e ao julgamento das situações vividas por outras pessoas desempregadas, Mário aponta para alguns desencontros: entre sua qualificação e o que sabe fazer e também entre os esforços realizados e os resultados alcançados. Em sua fala, a noção de profissão aparece como o que se aprende a fazer em cursos e a qualificação como o grau de escolaridade alcançado. Ele tem 
ensino médio incompleto e vários cursos, mas não consegue nada porque a escolaridade e a experiência registrada não lhe favorecem ${ }^{138}$.

Desse modo, o acúmulo de cursos de qualificação, ao aumentar as expectativas em relação ao ingresso no mercado de trabalho, opera como catalisador da tensão entre aquilo que Mário foi ensinado a querer e aquilo que de fato lhe é possível. No diagnóstico que faz da situação atual, Mário percebe a necessidade de se comportar como alguém sempre interessado em aprender. Mas, por outro lado, nota que os discursos que constroem a empregabilidade a partir do acúmulo de qualificação se tornam vazios quando se trata da primeira inserção no mercado de trabalho, pois os cursos que faz não têm sentido em si mesmos e não são suficientes para lhe conferir uma identidade profissional. Para traduzir os cursos em prática profissional, seria necessário que ele já estivesse trabalhando; como não é isto o que acontece, os diversos cursos realizados cumprem a função de estratégia para a sobrevivência identitária, possibilitando a crítica aos desencontros entre os valores em circulação e as práticas vigentes no mercado de trabalho.

A sua e a minha época: os conflitos com os pais - A questão do conflito dentro da família apareceu em vários momentos na narrativa de Mário: "é aquela questão, quando eu vou procurar emprego, minha mãe fala "ah, na minha época, não sei o que..."; e eu falo "mãe, na sua época", eu falo até às vezes para minha mãe assim "Você não sabe como é que está lá fora", ela só falta me bater na cara "Eu sei como é lá fora porque eu já vivi" mas naquela época era um jeito, há mais de dez anos atrás era um jeito; agora é de outro, está pior. (...) Hoje não dá, hoje o jovem - por isso que vira bandido e essas coisas - por que não dá oportunidades. Meus amigos mesmo, já aprontaram de tudo quanto é jeito - mas eles nunca contam isso para mim. Eu já

\footnotetext{
138 Lembre-se que Mário estava cursando o $3^{\circ}$ ano do ensino médio por ocasião da entrevista, o que também afetava sua disponibilidade para a procura - "faz mais de um ano que venho aqui, às vezes não posso vir de manhã a porque estudo de manhã e se eu vier a tarde não vou sair daqui tão cedo, vou embora tarde pra caramba, então acho que eu só vou conseguir arrumar um emprego, algum serviço, alguma coisa assim, que vou poder procurar, só no ano que vem, que vou ter terminado o ano, quero entrar numa faculdade (...) Mas só o ano que vem...".
} 
conheci, já vi, tenho amigos de todos os tipos de raça...Mas eu não me torno, eu não me tornaria; mas porque eu também, não sei, sou muito inteligente para isso".

Essa fala de Mário tem como objetivo principal mostrar que a mãe não entende sua opção porque não compreende a situação atual do mundo, julgando o comportamento do filho a partir de categorias que não condizem mais com a realidade. Por outro lado, Mário também demonstra aqui sua adesão a um dos discursos que mais circulam sobre a violência entre os jovens: a violência seria conseqüência da inexistência de oportunidades, diante de uma realidade pior do que aquela conhecida pelos pais ${ }^{139}$. Mário, porém, não acha que esse seja um caminho viável: ao contrário, assim como se posiciona criticamente em relação aos "bicos" encontrados pelos amigos, ele acredita que se trata de não ser tomado pela urgência imediata e de fazer escolhas tendo em vista um prazo mais longo; por isso, seu comentário sobre as atividades ilegais como uma alternativa ao desemprego é tão incisivo - "sou muito inteligente para isso".

Um dos principais fatores que fazem com que Mário se considere injustiçado está na falta de reconhecimento que os pais demonstram em relação à sua tenacidade. Inclusive, esse foi um dos motivos que mais pesaram em sua decisão em parar de procurar emprego por algum tempo: "eu estava com raiva, pô! Você está naquela: você procura, procura, você fica nas filas em várias agências e nada. Aí você (pensa), tenha calma, (diz para si mesmo) "não, vou dar um tempo", porque você não está conseguindo emprego e não tem como ficar bancando a passagem de ônibus. Tanto que eu já cansei de vir para Osasco a pé - eu moro em Carapicuíba. De Carapicuíba, também eu vou para Alphaville a pé - como se fosse daqui a, sei lá. Olha, sem preguiça vou procurar emprego. Agora, a raiva é que a minha mãe joga na cara, "ah, faz tudo isso e não consegue arrumar emprego"; os cursos que eu faço quem banca

139 Em muitos espaços, trata-se de um risco real - ver, por exemplo, as narrativas de mães moradoras de uma favela na zona sul de São Paulo, colhidas por Caetano, 2004. Em outros casos, porém, tal temor é resultado da tentativa de compreender os significados da crise atual a partir da perspectiva que representa a "juventude" como um período de transição, rumo à integração no mundo dos adultos; ou, para dizer como Schehr, trata-se de uma interpretação constituída sob a ótica das culturas da estabilidade (cf. Schehr, 2000: 55), conferindo às mudanças um caráter anômico, o que dificulta a compreensão das novas formas de integração e sociabilidade que podem criar. 
tudo é o meu pai, mas ele joga na cara "Para que tanto curso que você está fazendo se você não consegue nada?"; minha mãe fala "para que esses cursos que você está fazendo e não consegue, não está fazendo nada?".

Como ele, vários jovens, notadamente do sexo masculino, relataram a mesma inconformação: foram criados por pais que acreditavam que os estudos poderiam se transformar em mobilidade ascendente, tanto para seus filhos quanto para eles próprios, devido aos códigos de solidariedade familiar que obrigam os filhos a cuidarem dos pais, quando estes se tornam incapazes de trabalhar. Os conflitos entre pais e filhos aparecem nesse momento de entrada no mercado de trabalho, quando os jovens percebem a insuficiência da escolaridade atingida e, ou se empregam no que aparece ou perseguem mais escolaridade, arriscando-se a serem estigmatizados como folgados ou preguiçosos. Além disso, como se trata da constituição de uma empregabilidade duvidosa, muitos deles continuam sem trabalho, e são obrigados a ouvir de pais e parentes acerca da inutilidade de tanto estudo.

Os esforços de Mário são entendidos pelos pais - pela mãe principalmente, já que o padrasto que o criou desde pequeno foi quem impediu que ele trabalhasse ou procurasse emprego antes dos 16 anos - como recusa a assumir um trabalho comum: "Eu sei, a minha mãe me fala que sou um pouco meio ganancioso; mas eu não sou ganancioso, eu tenho um objetivo, não vou querer assim, começar de baixo. Eu não quero ser aqui de baixo, eu quero ser alguém. Então, eu não quero ir trabalhar na vaga de pedreiro, esses negócios. Meu, se o cara for pedreiro ele não vai crescer, se eu fizer serviço para alguém, ou trabalhar em mercadinho de esquina, eu não vou crescer. Eu quero trabalhar em alguma coisa que eu sei, que eu saiba que eu vou desenvolver; que ali dentro eu vou ter como recorrer a uma promoção ou qualquer coisa parecida". Mais uma vez, trata-se de recusar um trabalho percebido como esvaziado de sentido - Mário estrutura sua compreensão sobre a própria situação a partir da idéia de carreira ${ }^{140}$. Enquanto sua mãe demonstra se

\footnotetext{
${ }^{140}$ Como sublinha Sennett, a atual concepção de trabalho, caracterizado pela flexibilidade e pela adaptação às necessidades (sejam elas da empresa, do mercado ou da produção), contrapõe-se à idéia de carreira que marcava as relações entre as pessoas e o trabalho: "Essa ênfase na flexibilidade está mudando o próprio significado do trabalho, e também as palavras que empregamos para ele.
} 
preocupar que as pretensões irreais do filho terminem por lhe transformar num preguiçoso (operação pelo meio da qual ela reafirma a importância do trabalho para a constituição da moralidade), Mário expressa a adesão a um imaginário ancorado num mundo do trabalho que não existe mais.

O conflito se dá também em relação ao curso superior que ele deverá fazer. Contando de seus planos para começar a trabalhar e pagar a faculdade, Mário relata: "Matrícula, essas coisas, meu pai disse que vai bancar para mim - ele vai jogar na cara e tudo mas ele vai bancar. É...Que nem, ele falou que para fazer o curso na UNIP, por ele eu fazia Direito, qualquer curso que você entrasse na área de política; mas minha área é gráfica. O que me empolga mais o computador, tirando a matemática, fica o computador. Aí eu tento fazer alguma coisa, não sei: faculdade mesmo acho que não vou ter condições de fazer agora, porque vou ter que arrumar um emprego para poder bancar a faculdade, por que também não quero viver na situação insuportável de depois jogar na cara. Se ele já joga na cara por ele ter me criado nesses 16 anos, porque não vai jogar na cara (a faculdade)?". Aparece aqui um conflito claro entre a vontade do pai para que o filho siga seus passos, inclusive aproveitando sua rede de contatos, e o desejo do filho de se dedicar a um trabalho que seja prazeroso, que lhe permita ser independente - mesmo que para isso seja necessário batalhar usando seus próprios meios. Talvez por isso também seja tão importante para Mário construir o merecimento: ele precisa afirmar seus próprios méritos, tanto técnicos quanto "morais", para mostrar à família que é possível construir outros caminhos, desde que haja persistência e inteligência, os dois atributos para os quais ele mais chama a atenção.

Há também, nesse esforço por trilhar o seu próprio caminho, uma recusa ao tipo de trabalho feito pelo pai. Segundo me contou, seu pai tem times de rúgbi e futebol, é assessor de políticos e também possui um escritório - cujas atividades não consegui identificar. Foi nesse escritório que Mário trabalhou

\footnotetext{
'Carreira', por exemplo, significava originalmente, na lingua inglesa, uma estrada para carruagens, e, como acabou sendo aplicada ao trabalho, um canal para as atividades econômicas de alguém durante a vida inteira. O capitalismo flexível bloqueou a estrada reta da carreira, desviando de repente os empregados de um tipo de trabalho para outro. A palavra 'job' [serviço, emprego], em inglês do século quatorze, queria dizer um bloco ou parte de alguma coisa que se podia transportar numa carroça de um lado para o outro. A flexibilidade hoje traz de volta esse sentido arcano de job, na medida em que as pessoas fazem blocos, partes de trabalho, no curso de uma vida", (Sennett, 2004:10).
} 
por algum tempo, e ele relatou a discordância que tinha em relação ao comportamento do pai no tratamento com os empregados: "Tantas vezes eu já briguei com ele, quando eu saí do escritório eu estava querendo uma remuneração e ele não dava; quem trabalhava na mesma área lá, trabalhava com meu pai no escritório recebia acima de $R \$ 200,00$ e eu trabalhava como digitador, um monte de coisa lá. E eu trabalhava para ele e recebia $R \$ 50,00$, só porque eu sou filho dele? Isso não vale. E meu pai não trabalha com nenhum cadastrado, mas, então é aquele negócio, tem que acatar o que ele fala e eu não acho certo isso". Desse modo, é possível imaginar que o esforço realizado por Mário para construir seu próprio caminho se liga ao esforço por escapar a esta ordem privada descrita por ele; o desejo por um emprego aparece, assim, como o contraponto a tais relações hierárquicas e autoritárias já que Mário reconhece que os desmandos só ocorrem porque não existem leis que alcancem os funcionários do pai.

Quando Mário fala das expectativas que tem para quando começar, finalmente, a trabalhar, fica explícito que a entrada no mundo do trabalho tem ainda - o caráter de emancipação, de assunção da responsabilidade pela própria vida e impressiona a animação com que Mário traça o cenário das mudanças: "vixe! Vai mudar tudo! Olha, é que nem eu fico pensando, eu estou na escola, tem aquela rotina da escola, na minha casa, videogame. Agora, vou te falar, quando arrumar um emprego e não estiver na escola muda completamente, você vai perceber, muda completamente, a pessoa tem que ter mais responsabilidade, ela vai ter que tomar noção de que ela não vai mais depender da família e, se você sai da escola, você tem que arrumar alguma coisa para fazer". Menos do que fugir da responsabilidade menos do que falta de "coragem para o trabalho"-, o que aparece no relato de Mário é a possibilidade de realização daquilo que é esperado de um jovem após a saída da escola. Mais uma vez, é de constituição identitária que se trata e também das dificuldades implicadas em realizá-la por meio do início das atividades profissionais ${ }^{141}$.

\footnotetext{
${ }^{141}$ Sobre a assunção de responsabilidades e o sentimento de independência em relação aos pais, é interessante tomar como exemplo a filha mais velha de José, Flávia. Estimulada pelo pai, que não poderia satisfazer suas vontades de consumo, Flávia começou a procurar emprego aos 14 anos. Só começou a trabalhar de fato após os 16 - devido aos limites legais para o emprego -
} 
A recusa ao trabalho pesado: bicos e empregos - Quando tinha 15 anos, a mãe de Mário arranjou trabalho para ele num mercadinho perto de sua casa. $\mathrm{O}$ padrasto, no entanto, não permitiu que ele fosse trabalhar, afirmando a importância dos estudos. Mário reconhece nessa postura paterna a sua própria convicção de que é preciso trabalhar em alguma atividade que abra as perspectivas para o futuro. Além disso, acredita que se seus amigos não compartilham dessa mesma noção é porque os pais não souberam educá-los: “(meus amigos) são muito acomodados. A maioria...Olha, eles viveram sempre na rua, os pais não souberam educar eles dentro de casa para querer um objetivo, eu já tive um pai - meu pai é padrasto, ele me criou desde pequeno, desde os três anos de idade. Então, ele que me pôs, me criou ali dentro. Eu só não comecei a trabalhar desde cedo porque ele não deixou".

Não é possível deixar de notar que a construção dos valores e atributos morais que Mário relaciona à capacidade de construir um projeto de futuro e de perseguir tenazmente alguns objetivos se dá no espaço da casa; os amigos, que viveram na rua, conformam-se aos trabalhos precários que aparecem e não pensam num prazo mais longo. A tensão entre os valores da casa e os valores da rua, aparece aqui de modo bastante evidente, reforçando o caráter privado da moralidade que sustenta o comportamento de Mário pelo mercado de trabalho e, por extensão, a idéia de que o merecimento é tão ou mais importante para a sustentação da identidade quanto os atributos de empregabilidade ${ }^{142}$.

A recusa ao trabalho pesado se dá tanto pela sensação de que "não sabe" desempenhá-lo quanto pelo entendimento de que se trata de um tipo de trabalho que não oferece perspectivas de desenvolvimento profissional. Mário concentra, assim, seus esforços de entrada no mercado de trabalho na área na

como atendente em lojas de comércio. Sua boa aparência lhe facilita o trânsito pelo mercado de trabalho e ela logo conseguiu um emprego melhor que o primeiro, abandonando os estudos mesmo contra a vontade dos pais e se casando aos 17 anos. O início do trabalho, portanto, coincidiu com a responsabilização pela própria vida, inclusive em relação a assuntos (o abandono da escola e o casamento) sobre os quais não lhe caberia decidir se não tivesse iniciado seu caminho de se tornar independente dos pais.

${ }^{142}$ Cf. a fecunda interpretação de Da Matta (1991). 
qual fez seus cursos; como vimos acima, no seu modo de entender, ainda que não tenha começado a trabalhar, ele já possui uma profissão: "por que olha: minha área é gráfica, meu conhecimento é esse. Minha mãe quer que eu faça o quê? A minha mãe, por ela, estaria trabalhando de pedreiro. então, ela me vê nessas coisas. Mas o que é que adianta eu ficar trabalhando nisso se eu não sei, eu não consigo, eu não consigo nem carregar, eu tenho força mas carregar um saco de cimento, nem isso eu consigo. $\mathrm{O}$ negócio para mim é coisa que raciocina, que tem que pensar; para você ver, eu mesmo estudo sozinho: psicologia, filosofia, essas coisinhas; mesmo matemática. Mas não dá, a minha coisa não é coisa de ser pesado, nada pesado".

É interessante também notar a distinção que ele opera entre o trabalho pesado e o trabalho que envolve raciocínio - ainda que os discursos sobre empregabilidade em circulação se esforcem em construir a figura do novo trabalhador como alguém que é capaz de fazer $e$ pensar. Nas falas de Mário aparece claramente a idéia de que são poucos os trabalhos que, efetivamente, exigem que o trabalhador conjugue suas habilidades físicas e capacidade de raciocínio. A inutilidade das exigências de escolaridade para o desempenho de determinadas tarefas ganha aqui um importante argumento pois a escolaridade ou não é relevante para o desempenho de tarefas pesadas ou não é suficiente para o desempenho de trabalho "intelectual"143.

Comentando o comportamento dos amigos em relação ao trabalho, Mário é categórico: "eles não têm futuro (os amigos); eles não pensam em fazer faculdade, eles não pensam em crescer na vida, que nem eu acho que eles vão sempre viver fazendo bico e o pessoal...Eu sou daqueles, não sou de ficar na rua, jogando bola; eu gosto de ler, gosto de viajar mesmo! Faço tudo de várias coisas, mas não sei o que é que dá. Às

\footnotetext{
${ }^{143}$ A crítica aos padrões de escolaridade exigidos para o desempenho de tarefas que não exigem qualificação alguma aparece em diversos relatos - tanto nas falas de adultos quanto na dos jovens. A diferença consiste em que, principalmente quando não possuem escolaridade, os adultos tendem a considerar a escolaridade como algo importante, a que deveriam ter prestado atenção para evitar a situação de desemprego em que se encontram; quanto aos jovens, alguns apostam na escola como forma de acessar melhores postos de trabalho e outros explicitam que se trata de um atributo necessário mas não suficiente. Sobre as relações entre os jovens e a escola, ver Souza (2003) e Caetano (2004). Sobre o papel desempenhado pela escolaridade quando da entrada no mercado de trabalho, ver H. Martins (1997 e 2004). Para uma crítica da escolaridade como forma privilegiada de inserir os jovens no mercado de trabalho, ver Trevisan, 2004 e Madeira, 1983.
} 
vezes, acho que é falta de religião também, eu não tenho nenhuma. Mas eles não querem nada da vida; hoje em dia o jovem não quer nada, a maioria. Muitos querem a faculdade, mas eu acho que...". Aqui Mário retoma a sua convicção de que o trabalho pesado não permite perspectivas de um futuro diferente. Por outro lado, essa fala também é interessante porque revela que, a despeito desta convicção, Mário carece de uma estratégia que claramente poderia levá-lo a alcançar seus objetivos: vai fazendo cursos, vai entregando currículos, vai estudando por conta própria, mas não sabe onde é que vai dar.

É nesse sentido que acredito que as narrativas juvenis nos permitem recolher elementos que iluminam algumas mudanças que ocorreram e ocorrem no mundo do trabalho. As estratégias que estes jovens foram ensinados a utilizar se revelam ineficazes, incapazes de cumprir as promessas de inserção no mercado de trabalho. Sem compreender direito o que se passa - apenas compreendendo que algo mudou - alguns jovens insistem nas formas conhecidas: aumento da escolaridade, procura por qualificação, realização de cursos complementares que estejam ao seu alcance (por exemplo, de informática e inglês). Mas o desencontro entre essas formas herdadas e o presente aparece sob a forma de desemprego prolongado, conflito com os pais e adiamento da transição para a vida adulta.

Nesses desencontros, que tanto eles quanto seus pais percebem, manifestase a crescente dificuldade de constituição de uma carreira nos moldes conhecidos e a conseqüente necessidade de reinvenção constante das próprias relações com o trabalho ao longo da vida profissional144. O que fica claro, no entanto, a partir da fala de Mário, é que a idéia mesma de trajetória passa a ser o resultado de uma seqüência de escolhas e ações que encontram na idéia de "sorte" seu principal fator explicativo ${ }^{145}$ - não à toa, após dois anos de procura,

144 Sobre a constante necessidade de reinvenção ao longo do período "economicamente ativo" da vida de uma pessoa, ver Sennett, 2004 e Dowbor, 2001.

145 Machado Pais, tratando das trajetórias de jovens portugueses, mostra que a incerteza emerge como característica principal, e é por isso que ele nomeia os percursos trilhados pelos jovens como "labirintos" e as trajetórias como "yô-yô", sublinhando que freqüentemente os jovens vão construindo seus percursos na própria experiência do caminho - assim, não há planejamento de longo prazo, mas idas e vindas, que impossibilitam que a transição para a vida adulta seja 
Mário cogita se não será possível atribuir à sua falta de religião a responsabilidade por não encontrar emprego.

É assim, na encruzilhada entre lógicas tão distintas (sorte/competência, empregabilidade/merecimento) que Mário procura construir seu próprio caminho, distinguindo-se de seus amigos e do que ele mesmo considera que sejam as expectativas "do jovem": "hoje em dia a maioria dos meus amigos, por eles é qualquer coisa, para eles está bom. Mas eu não sou assim, eu não quero qualquer coisa, eu quero alguma coisa de acordo com a minha capacidade".

"Como é que eu vou me atualizar sem emprego?" - Uma das principais preocupações de Mário em relação à demora em encontrar emprego se deve à sua compreensão de que é só a partir do momento em que estiver trabalhando e ganhando seu próprio dinheiro é que vai conseguir pagar sua faculdade e continuar a fazer cursos. Trata-se de começar a trabalhar para se tornar e se manter empregável e este é o objetivo que sustenta seu comportamento de procura mesmo quando está cansado ou com raiva: "é que eu tenho um objetivo, se eu não conseguir, se não arrumar um emprego, eu não vou começar. Eu pretendo fazer faculdade no ano que vem e não tenho condições de pagar nem a inscrição de uma faculdade agora...".

O impulso de começar a trabalhar e pagar suas despesas também está relacionado à situação familiar: "Então, na minha casa está uma situação muito ruim, então meu pai não tem como me ajudar nas passagens. Aí, minha amiga está me emprestando o dinheiro, para eu continuar fazendo os cursos na Fundação Bradesco". Ainda que não tenha condições de pagar as passagens para procurar emprego ou para fazer cursos, Mário avalia que seria pior interromper essas atividades, pondo em risco os conhecimentos que acredita já ter acumulado.

$\mathrm{Na}$ origem desse comportamento tenaz está a percepção da rápida obsolescência a que estão sujeitos aqueles que ficam afastados do mercado de trabalho - as experiências se perdem em meio às inovações e a única maneira de voltar ao ponto de origem e assim em relação a todas esferas da vida (Pais, 2001). 
acompanhar o ritmo é estando inserido no mercado de trabalho. Essa percepção se expressa na análise que Mário faz do mercado gráfico: "é aquele negócio, as pessoas perdem o emprego. E aí quando vão procurar já não têm idade para procurar; agora também pedem uma qualificação muito grande, tem gente que tem assinatura de emprego há uns anos atrás, vamos dizer, que nem na área gráfica, se a pessoa tem experiência, dez anos de carteira de há dez anos atrás, não vai servir para hoje, porque há dez anos atrás se trabalhava com tipografia (tipografia ainda tem), se trabalhava com máquinas de impressão, manual. Hoje em dia tem offset, que é impressão a laser, pior ainda. Então, aí não tem vaga, só em gráfica pequena. Hoje em dia o mercado está evoluindo demais, se a pessoa que não seguir o ritmo do mercado, ela não cresce. O meu computador, coitado... não agüenta, eu não posso trabalhar com programas de gráfica que eu conheci - porque vende alguns, até para eu não esquecer, se eu não trabalhar logo - eu não posso pôr no meu computador alguns programas porque ele não suporta. Agora, eu vou ter que sempre estar me atualizando. Como é que eu vou me atualizar sem emprego? Eu já poderia estar montando um negócio próprio, só meu, mas não posso. Então, a pessoa que quer crescer, ela tem que ir seguindo o ritmo da empresa ou melhor do mercado".

Mais uma vez, Mário distingue a vontade de aprender uma profissão do caráter das coisas que se aprende na escola: “E, por exemplo, eu luto porque quero conhecer, quero ver - tudo ligado ao emprego, porque sou péssimo de escola - mas, aqui fora, a pessoa nunca é alguma coisa dentro da escola do que aqui fora, aqui fora a pessoa mostra o valor dela muito maior do que na escola. E eles exigem grau de escolaridade, não adianta o grau de escolaridade, ela terminou o terceiro ano, mas ela não começou a se capacitar lá fora. A escola é só o início, não ajuda quase nada, a gente sem emprego é uma caca, espero que melhore agora. Mas agora está melhor, assim, a pessoa que quer ver e quer conhecer".

A complementaridade necessária entre capacitação e experiência se evidencia nessa fala, e Mário mostra que a escola não prepara para a vida, é só o início: o valor de alguém está dado pelo trabalho, pelo emprego que possui ${ }^{146}$.

\footnotetext{
146 Regina Magalhães de Souza, entrevistando jovens alunos de escolas públicas, constatou que eles não acreditam que os conhecimentos aprendidos na escola tenham alguma utilidade para sua vida ou seu trabalho; a valorização da escola não se dá, desse modo, devido aos conteúdos
} 
É essa vinculação que ele identifica entre emprego e valor pessoal que o faz sonhar em ser dono de uma empresa, de preferência grande, que gerasse muitos postos de trabalho: "Еu me sinto até mal; olha, eu luto por alguma coisa porque às vezes eu vejo, eu quero abrir uma empresa para dar oportunidade para esses caras; aí, eu que falo, eu quero ser alguém grande; eu falo: eu ainda vou ter a minha multinacional aqui no Brasil. Eu falo, não sei se é brincando, não sei o que vai acontecer, mas eu falo, que quero abrir uma empresa, não importa no que for, mas o que vale é que tenha emprego". Por trás dessa fantasia, será que não podemos identificar o desejo de Mário de ter algum controle sobre os processos que envolvem a vida dos trabalhadores; uma forma, assim, de superar a batalha diária para chegar a um resultado que não se sabe bem qual será? Essa fala de Mário é interessante porque, naquilo que projeta de sonhos e possibilidades, revela muito do mundo de trabalho que ele esperava encontrar: ele sonha em se livrar da necessidade de se empregar, sonha em usufruir de algum grau de governabilidade sobre sua vida - sonha, enfim, em deixar de depender da sorte ${ }^{147}$.

\section{Sorte e merecimento: o que é justo e o que é injusto? - Na crítica que} Mário faz a seus amigos, não estão incluídos apenas aqueles que trabalham em "bicos", mas também aqueles que não trabalham e nem se interessam em trabalhar. É no confronto de sua situação com a de amigos que Mário torna mais evidente sua percepção de que a vida lhe é injusta - principalmente porque seus pais não reconhecem que ele se distingue dos jovens de sua geração: "Só que tem gente que...vixe! Os pais dele nem ligam. Eu tenho um amigo lá

que nela se procura transmitir, mas na sociabilidade, nas relações e interações que se estabelecem lá dentro (Souza, 2003). Maria Inês Caetano também observou que o valor atribuído à escola está carregado de ambigüidade pois mesmo os jovens que afirmam o valor da escola, mais adiante revelam que não gostam de estudar ou ler: assim, o valor da escola é, no mais das vezes, instrumental e o diploma tem mais utilidade do que as coisas que se aprende naquele espaço, (Caetano, 2004, especialmente página 395 e seguintes).

147 Em muitos aspectos, a narrativa de Mário revela uma realidade bastante próxima a dos "recém-chegados" entrevistados por Suzanna Sochaczewski: "Os recém-chegados têm como meta terminar o segundo grau, em alguns casos falta até completar o primeiro grau. Sua situação é bem diferente daquela dos herdeiros. Ganhando pouco e com um alto indice de rotatividade, reconhecem que têm pouca chance de freqüentar uma faculdade mas apostam em cursos de nível técnico de curta duração como um instrumento para subir na vida. Seus sonhos profissionais passam pelo trabalho por conta própria - uma padaria, um mercadinho, uma mecânica - ou então pela medicina e arquitetura, também pensadas como profissões liberais", (Sochaczewski, 1998:179). 
que está desempregado, os pais dele dão de tudo: deu um computador, nível XP; deu videogame, e deu tudo o que o moleque... E o moleque não faz nada e consegue coisas assim. Agora eu estudando para ser alguém na vida e os pais não vêem nada disso...(...) Olha, eu tenho uma amiga minha que faz cursos adoidado e nunca trabalhou nisso, mas faz curso. Agora, ao invés dela ter noção e a dar oportunidade para aqueles que querem mesmo prestar na área gráfica, ela vai fazer o curso - você toma vaga de outros - (...). Outro dia, tem um lá que fala "Eu quero trabalhar na área gráfica" e aí tem uns que você pergunta lá, o que você quer fazer, por que você está nesse curso, "Ah, minha mãe mandou, minha mãe mandou fazer o curso". A mesma coisa para procurar emprego, tem gente que vem procurar emprego, jovens, que vem procurar emprego porque a mãe mandou! Nunca vai arrumar, por que não gosta. Às vezes arruma, não é? De tão desencanado que é. Agora eu, que eu quero arrumar...Que nem, um amigo meu arrumou emprego eu falei "E aí, você arrumou um emprego?", (e ele) "Pior que eu arrumei, cara". Pô, eu não acredito: tem cara que não faz nada na vida e consegue um emprego. Eu que luto, batalho, estudo, eu não consigo nada".

Crítica aos amigos que se conformam com pouco, crítica àqueles que recebem tudo com facilidade: os períodos de raiva e desânimo que Mário experimenta têm a ver com essa luta constante (é impressionante observar quantas vezes as palavras "luta" e "batalha" aparecem em sua narrativa) e a falta de recompensa aos seus esforços. Nem encontra um emprego, nem encontra reconhecimento por parte dos pais - sem emprego, fica uma "caca", pois impossibilitado de ter acesso a esses dois grandes eixos constitutivos da identidade (família e trabalho), fica difícil até mesmo sustentar o discurso sobre sua própria capacidade e inteligência. O que Mário mais deseja é começar a trabalhar, assumindo o controle de sua vida e as responsabilidades que reconhece ter com a família. Como sua fala revela em vários momentos, ele não está querendo nada demais, não está sendo ganancioso, não está sonhando coisas impossíveis. A única coisa que deseja é "se encontrar", num trabalho que lhe dê chances de se desenvolver e que recompense suas capacidades. Enquanto não começa a trabalhar, a única saída que lhe resta é continuar em movimento, até como forma de sustentar suas expectativas e de tentar acompanhar o ritmo de um mercado do qual está excluído: "É muito difícil, eu te falo, às vezes eu fico 
injuriado, com raiva, às vezes não. Às vezes eu me desanimo, que nem, antigamente, às vezes eu preferia ficar deitado lá, assim. Porque eu olho, algumas pessoas, como é que elas conseguem viver tão bem? Filho único é uma beleza, recebe tudo do pai, agora quando tem assim - eu tenho mais quatro irmãos - meu pai não mora em casa, é muito mais difícil. Eu mesmo falo que eu gostaria (de arrumar um emprego) porque eu vou saber ajudar em casa, meu irmão não ajuda, eu gosto de ajudar. Eu quero arrumar, espero que nessa dessa vez aí apareça alguma coisa para mim, porque eu tenho que mudar tudinho o que está escrito lá...". 


\section{II - "Agora é só aguardar" - Alessandra}

Alessandra tem 21 anos; branca, estatura média, cabelos compridos e uma voz suave, Alessandra perdeu ambos os pais e vive com os irmãos - que são seis (dois irmãos e duas irmãs mais velhas, ela e um irmão, o caçula) e moram todos juntos. Na época da entrevista, realizada em janeiro de 2003, apenas três estavam trabalhando e os outros três se encontravam desempregados - "Eles estavam trabalhando agora, na Frente de Trabalho, né? Acabou o contrato e estão parados agora".

Alessandra tem o segundo grau completo e fez curso para auxiliar de enfermagem, embora nunca tenha exercido a profissão a não ser no período de estágio obrigatório. Por ocasião da entrevista, estava desempregada há dois anos e durante alguns períodos alternados, parava de procurar, desanimada por não encontrar nada - "Porque, ai, às vezes desmotiva, né? E aí você não tem dinheiro e aí você vai andar a pé e aí você anda, anda, e as pessoas falam a mesma coisa, "ai, é para aguardar, aguardar", chega uma hora que desanima. Às vezes fico tempo e tempo, sem sair mesmo, porque desanima".

Antes deste prolongado período de desemprego, Alessandra chegou a trabalhar - nada muito especializado, mas de todo jeito, tratava-se de uma inserção no mercado de trabalho: "já trabalhei como balconista, mas já tem dois anos que eu tô parada. Aí depois de um tempo fiz um curso, de auxiliar de enfermagem, só que está difícil, porque eles exigem experiência...Se não tiver alguém para encaixar a pessoa dentro do hospital, não tem como...Já mandei muitos currículos, já preenchi várias fichas e tal, para a área da enfermagem, mas não consegui, nem para enfermagem nem pra área que eu trabalhava antes também, né? Eu acho que...Eu não sei se é porque eu estou muito tempo parada e então, a gente vai, vai atrás e não sei se é pelo tempo, a gente acaba não conseguindo, eu acho que é isso". Ao olhar para sua experiência de desemprego, Alessandra traz à frente da cena alguns elementos importantes: a busca por um curso de auxiliar de enfermagem como resposta ao desemprego, a dificuldade de conseguir um emprego sem conhecer as pessoas "certas" e a 
compreensão de que o tempo prolongado de desemprego acaba por se transformar numa barreira que se soma à falta de experiência ou qualificação ${ }^{148}$.

Nesta fala de Alessandra, evidencia-se uma diferença interessante em relação à narrativa de Mário: enquanto ele expressa uma certa confusão em relação ao que é experiência, o que é qualificação e o que é profissão, Alessandra deixa claro que fazer um curso é apenas o primeiro passo. O início do trabalho, a realização profissional (contratada e remunerada) da atividade aprendida, portanto, é que transforma um "curso" em profissão; enquanto não estiverem vinculados ao aprimoramento da prática, os cursos acabam cumprindo apenas uma importante função simbólica que é a de construção do merecimento por meio da demonstração de um comportamento de constante "desenvolvimento pessoal"; trata-se de uma maneira de viver tendo o mercado de trabalho como referência, ainda que se esteja apartado dele. Voltarei a esse tema a partir da trajetória de Lutemberg, pois as mudanças de significados pelas quais os estudos passam também aparecem em sua experiência de faculdade e na observação do perfil de seus colegas de turma.

No caso de Alessandra, ela observa que não foi a única a terminar o curso de auxiliar enfermagem sem a perspectiva de um emprego: "Da turma que a gente fez o curso, são poucos que estão trabalhando, né? São muito poucos..."149. Ela

\footnotetext{
148 Vale lembrar que, quando se toma a taxa de desemprego aberto para 2001, as mulheres na faixa etária dos 18 aos 24 anos (as jovens, portanto) concentram 20,6\% dos desempregados. Conforme discussão feita no Capítulo 1 .

${ }^{149}$ Entrevistei algumas mulheres que ou já haviam feito o curso de enfermagem ou sonhavam fazer. Uma delas, Soraia, (26 anos, procurando há um ano e em situação de desemprego oculto por trabalho precário), relatou estar formada há três anos como auxiliar de enfermagem, ser filiada ao Coren (Conselho Regional de Enfermagem) e nunca ter conseguido trabalhar na área - em grande parte por não ter experiência ou contatos). Ela trabalha como promotora de vendas em supermercados, demonstrando produtos. A narrativa de Soraia é bem interessante: ela é uma mulher bonita e bem articulada e chegou a se mudar para Maceió, onde vive o irmão, para ver se conseguia trabalho. A rede de contatos do irmão, porém, era restrita aos comerciantes da cidade e por isso ela só conseguiu trabalho numa livraria. Como o trabalho não era o que ela desejava e a remuneração também era bem inferior àquela que ela conseguia com seus trabalhos de promotora, quando seu cachorro ficou doente de saudade, ela decidiu voltar para São Paulo, dizendo que mesmo desempregada, sua vida aqui era melhor do que lá (ela se referia principalmente aos costumes de lazer e alimentação). Um dos fatores apontados por Soraia para a dificuldade em encontrar emprego na área de enfermagem é a baixa remuneração dos auxiliares de enfermagem que, assim, são obrigados a trabalhar em dois ou três empregos. Além disso, por trabalharem muito, não conseguem fazer uma faculdade, que lhes permitiria passarem a enfermeiros, e ficam fadados a permanência na mesma função. Referi-me aqui à
} 
atribui essa situação tanto à dificuldade de ser contratada por um hospital sem conhecer alguém que já trabalhe lá, e que possa intermediar o contato, quanto à natureza do serviço prestado: em sua região, a maior parte dos hospitais são públicos, e é necessário participar de concursos que são bastante concorridos "E às vezes são poucas vagas, você concorre - às vezes para cem vagas são mil pessoas para cem vagas, é meio complicado...". É interessante notar a diferença que esse modo de significar os concursos apresenta em relação à narrativa de Suely, por exemplo. Enquanto Suely valoriza os concursos por considerá-los processos seletivos que premiam a competência (e não atributos pessoais tais como a aparência), Alessandra fica desanimada diante da imensa concorrência e embora saiba que se trata de uma saída possível, esta não se apresenta de modo algum como uma saída mais fácil.

O seu modo de procurar é o mesmo que o da maior parte dos jovens entrevistados: "eu deixo currículo em agência...Em Carapicuíba tem um posto tipo que nem assim (o Centro de Solidariedade ${ }^{150}$ ), né? Lá eu já fui também, lá não aparece nada também. Às vezes aparece, mas é longe, você tem que pegar, uma, duas, três conduções, e a empresa não paga, quer uma pessoa só para (pagar) duas conduções". Alessandra aponta aqui para a escassez de postos de trabalho - não aparece nada - e para o desencontro entre o local onde se encontram os desempregados e o local onde se encontram os empregos. Esse desencontro, aliás, apareceu na fala de vários dos entrevistados: moradores de cidades que, embora grandes, têm a dinâmica bastante relacionada à da cidade de São Paulo e assim, devido à distância dos centros comerciais desta, acabam sofrendo de dificuldades similares às encontradas por moradores de periferia151. Quando foram morar

narrativa de Soraia porque - talvez mesmo por suas experiências de trabalho - a capacidade de análise e crítica à própria situação que ela demonstra é bastante maior que a de Alessandra, ajudando-nos a compreender um pouco melhor a situação do mercado de trabalho enfrentado por esta. As dificuldades que enfrentam são basicamente as mesmas, mas o modo de lidar com elas é absolutamente distinto.

150 Aliás, trata-se do mesmo serviço. Como descrevi no Capítulo 2, dos serviços do Centro de Solidariedade também fazem parte os postos avançados, em parceria com os sindicatos locais.

151 Refiro-me aqui às longas distâncias que têm que ser percorridas até o trabalho, ao alto custo que isso acarreta em termos de tempo e de dinheiro - situações que se agravam quando, além da distância, os moradores vivem em bairros considerados perigosos, pois então o estigma se soma ao quadro de dificuldades; ver Sarti, 1985, especialmente capítulos 1 e 2. A distância em 
nessas cidades, muitas vezes por falta de opções devido aos altos custos de moradia em regiões centrais, ainda havia indústrias e empresas instaladas na região (no caso dos entrevistados, notadamente na zona Oeste de São Paulo e na região de Osasco'152); a desindustrialização os atinge, assim, duplamente: diminuindo a oferta de empregos e tornando mais distantes os locais de trabalho. Além disso, as altas taxas de desemprego acabam "facilitando a vida" do empregador, que pode impor sua condição de que os trabalhadores morem perto do serviço, diminuindo custos com transporte e com os atrasos resultantes dos engarrafamentos.

Alessandra acredita que quando ainda estava estudando, teve mais facilidade em começar a trabalhar: "foi mais fácil (encontrar emprego pela primeira vez). Uma que eu ainda estava estudando, então, eu era mais nova, tinha 18 anos, então, eles preferem mais quem ainda está estudando do que quem já terminou. Por que eu acho que quando a gente está ainda estudando, parece que é mais fácil conseguir um emprego; depois que você está parado, eu achei mais difícil agora, depois que já terminei tudo, já fiz um curso, achei mais difícil agora porque está muito concorrido mesmo". Não deixa de ser interessante notar que, enquanto Mário encontra imensas dificuldades em encontrar um primeiro emprego e acredita que o fato ainda estar estudando atrapalha suas procuras, Alessandra - que conseguiu seu primeiro emprego neste período de sua vida - entende que existe uma preferência por quem ainda está estudando. Em que pese os diferentes setores de atividade visados por um e por outro, a noção de "sorte" como fator explicativo ganha aqui mais força pois que as experiências que vivem estes jovens parecem definir seu modo de interpretar o presente - trata-se, assim, de uma interpretação informada pela aleatoriedade das experiências que lograram ter.

Outro aspecto importante nesta fala é que, mais uma vez, a concorrência emerge como explicação. Agora, não apenas relacionada aos concursos, mas ao

relação aos locais nos quais os trabalhos existem e acontecem foi apontada por vários entrevistados como uma barreira - à procura e ao encontro de um posto de trabalho.

152 A esse respeito, podemos relembrar a descrição de Fátima (Capítulo 4) sobre o esvaziamento dos antigos bairros industriais. 
mercado de trabalho em geral. É interessante destacar quais significados Alessandra atribui aos estudos: estar estudando é apenas uma etapa necessária a conseguir um emprego. Ao dizer que acha mais difícil encontrar um trabalho agora, depois que já terminou tudo, já fez um curso, Alessandra está dando notícia dos passos vistos como necessários ao início da vida profissional e da vida adulta. Terminar os estudos, nesse sentido, significa enfrentar a vida e a realidade encontrada por Alessandra é a do desemprego prolongado, que ela atribui a ter ficado mais velha, a estar muito tempo parada e à concorrência.

Por que a idéia de concorrência é tão presente na fala de Alessandra? Por que será que esta idéia aparece sempre "fechando" um argumento, atestando a dificuldade em encontrar um trabalho? Uma interpretação possível é que a idéia de concorrência assume tamanha força porque se trata do reconhecimento dos limites da própria formação, capacitação ou experiência ${ }^{153}$ : superar as barreiras - superando, assim, os "adversários" - implica em mais estudo, em estudo de melhor qualidade, ou seja, em novos investimentos, que Alessandra não tem condições de fazer (pois só teria se estivesse trabalhando).

É essa espécie de suspensão do presente que transparece nos relatos dos jovens que faz com que diversos autores atribuam às experiências juvenis nestes tempo um caráter de "moratória", significando com isso o constante adiamento da estabilidade (ver Pais, 2001, especialmente 401 e seguintes; Pais, 1997 e Bajoit e Franssen, 1997)

Ainda que não seja do meu interesse traçar um retrato pessimista dos problemas enfrentados pela juventude - ou por quaisquer de meus entrevistados - fica difícil não perceber que se trata de uma encalacradela, que também se expressa nas falas dos outros jovens que entrevistei: assim como Mário, Lutemberg e Rodolfo, Alessandra parece presa na armadilha da construção e manutenção de atributos de empregabilidade enquanto ainda não se começou a trabalhar. A principal diferença, no entanto, é que enquanto para Mário e Lutemberg a consciência da armadilha resulta em movimentos para escapar dela, para Alessandra essa consciência resulta numa certa "resignação".

153 Voltarei a esse tema a partir da narrativa de Lutemberg. 
Alessandra não falou de projetos de faculdade ou projetos de carreira; ao contrário dos outros três jovens em situação de desemprego oculto pelo desalento, ela sequer falou em sonhos profissionais, mesmo que fosse para reconhecer a impossibilidade de sua realização. Enquanto não se está trabalhando, não parecem haver horizontes.

Quando perguntei a ela o que esperava que fosse mudar quando começasse a trabalhar, Alessandra respondeu que "...a gente trabalhando, você tem a sua garantia ali no final do mês, tem seu dinheirinho para receber, aquela luta toda... ficando parado é muito difícil". Note-se apenas a diferença em relação à fala de Mário, para quem o início da atividade profissional estava ligado a tornar-se responsável por sua própria vida, a reorganizar o tempo e a contribuir com despesas: aqui, o único objetivo parece ser a remuneração ao final do mês, a esperança de alguma estabilidade. A idéia de que o tempo de trabalho é também um tempo de luta e de movimento e importante para a discussão que venho fazendo, pois revela que o movimento que produz a vida - e a sobrevivência - está ainda ancorado no trabalho. O tempo de desemprego é difícil, assim, pois fica-se sem garantias e sem um salário que dê sentido à passagem do mês: fica-se parado, no mesmo lugar154.

É claro que essa diferença também pode ser devida ao falecimento dos pais de Alessandra: a assunção precoce das responsabilidades pela própria vida, à ausência de um "estatuto de substituição", pode ter alterado os significados da entrada no mercado de trabalho. Afinal, quando já se é responsável pela

\footnotetext{
154 Quanto à distinção entre movimento e paralisia, é interessante resgatar o trabalho de Ecléa Bosi, que colheu memórias de velhos moradores de São Paulo. De todos os relatos, emerge o sentido da degradação provocada pela velhice uma vez que se fica condenado à paralisia: tendo dedicado sua vida ao trabalho, que a despeito de seu conteúdo, implicava em movimento, em produção e em provisão da família, ao final da vida, esses homens e mulheres se deparam com um mundo tão diferente daquele que habitavam e produziam que suas experiências se tornam incomunicáveis pois já não parecem contribuir para iluminar o presente (Bosi, 1994). O aspecto que gostaria de reter a partir do trabalho de Éclea Bosi se refere à figuração da juventude e da vida adulta como períodos de movimento e atenção à vida. O tempo prolongado de desemprego, assim, interrompe o fluxo da atividade e - tanto mais nos casos de desalento aqui analisados - contraria a ordem do ciclo da vida. Não à toa, desorganizam-se as etapas e as formas de transição à vida adulta, bem como se revisitam as relações inter-geracionais: o que a fala de Alessandra revela é a sensação de paralisia que a acomete uma vez que se encontra "excluída" do acesso ao trabalho e, em conseqüência, da possibilidade de lutar por sua vida.
} 
própria vida, que significado ritual poderia ter o ingresso no mercado de trabalho? De todo modo, talvez se pudesse contar com o suporte ou o estímulo dos pais, Alessandra tivesse mais ânimo para superar as dificuldades que enfrenta155 - o que não significa que a armadilha não fosse a mesma, como podemos observar a partir das outras trajetórias aqui expostas.

Contando sobre os períodos de interrupção da procura, Alessandra relata as atividades típicas de uma dona-de-casa (atividades tipicamente femininas, portanto): "eu fico em casa ou...Agora vou ver se arrumo algum curso para fazer, alguma coisa para...Porque eu estou cansada já de ficar em casa. Aí é, cuido da casa. Eu vejo assim: porque gosto muito de bordar, de fazer crochê, às vezes eu pego para fazer. E ai é onde às vezes ajuda um pouco, que eu ganho um dinheiro, é assim". Vale a pena observar que esse cotidiano relatado por ela é bastante diferente daquele relatado pelos jovens do sexo masculino - quando decidem interromper a procura, podem se envolver em outras atividades (lazer, cursos, leituras), mas não nos cuidados com a casa. Outro aspecto que é interessante observar se refere ao impulso para fazer um novo curso: ele aparece como uma alternativa à ficar restrita ao espaço da casa.

Embora esteja experimentando o desemprego prolongado, Alessandra continua assustada com o grande número de pessoas desempregadas: " $O$ desemprego está muito grande; a gente acha que não, né? Que nem hoje de manhã, eu cheguei e a fila já estava dando volta, lá embaixo, falei "Nossa!", a gente pensa que não mas o desemprego está muito grande".

Alessandra aponta algumas maneiras pelas quais o desemprego poderia ser superado: "acho que é dar mais oportunidades, não é? Eu penso assim, eles põem um anúncio - tem que ter, por exemplo auxiliar de enfermagem, 2 anos de experiência como que um recém-formado vai conseguir um emprego, acho que teria que dar mais oportunidades para quem está começando agora, eu acho que deveria ser assim, dar mais oportunidades mas não só para o pessoal que já tem experiência mas também para quem está começando agora, eu acho que teria que ser assim". Esse discurso da

\footnotetext{
155 Segundo me relatou, os irmãos não ligam dela estar em casa: “(eles) não implicam; eles nem dão
} bola". 
“oportunidade", que apareceu em muitas entrevistas tendo como perspectiva diferentes universos (jovens à procura do primeiro emprego, pessoas mais velhas, mulheres, mães, homens, negros etc.), reforça a interpretação que estou construindo a partir da fala dos jovens: a escolaridade completada ou os cursos realizados, entendidos como forma de preparação para o mercado de trabalho, carecem de sentido enquanto não se encontra uma oportunidade de experiência prática; uma oportunidade para se construir e dar visibilidade ao próprio valor.

A religião aparece como um importante recurso para a manutenção das forças: "eu sou evangélica, então eu acordo, procuro orar um pouco e sair de casa, sair com pensamento positivo, hoje eu penso assim". Porém, as constantes buscas frustradas (aliadas à falta de perspectivas que resulta da recomendação para que "aguarde") acabam minando as energias de Alessandra, em cujas falas o futuro ou não aparece ou aparece como incerteza e indefinição: “Entreguei já vários currículos. Penso até em desistir, né? Mas, falei, vou atrás, vou tentar procurar alguma coisa, quem sabe?".

\section{III - Entre o sonho e a realidade: Lutemberg}

Lutemberg tem 22 anos. Branco, estatura média, com ar de esportista (no dia da entrevista, ele estava com calça e agasalho de nylon), Lutemberg está no primeiro ano de administração. Quando nos encontramos, em abril de 2003, ele estava desempregado há um ano e cinco meses. Neste período, segundo me relatou, Lutemberg chegou a ficar durante cinco meses dentro de casa, sem procurar emprego. Quando perguntei a ele o que fazia durante esse período, ele respondeu: "Ficava em casa chorando quase a maioria do tempo. Minha mãe falando, minha avó, uma cobrança interna, sabe, de casa. Eu estava desanimado de tudo mesmo, não estava com vontade de sair de casa, a amizade foi afastando. Porque você tem amigos só quando está bem não é? Quando você está ruim é difícil aparecer seus amigos".

Lutemberg não está à procura do primeiro emprego: “Trabalhei um ano na Tramontina e depois trabalhei numa loja de comércio, aqui em Osasco mesmo, só que eu pagava para trabalhar praticamente, porque não dava nada e o salário tinha que pagar 
tudo, aí não tinha como eu continuar, entendeu? Deixa eu ver mais, eu trabalhei com minha prima, com algumas coisas assim... se for somar tudo, eu trabalhei no máximo dois anos". Desses dois anos trabalhados, um ano e seis meses estão registrados na carteira.

Existe uma razão que me faz ter um especial carinho pela entrevista com Lutemberg. Sua narrativa foi uma surpresa, pois nenhum individuo do sexo masculino havia chegado a dizer que passara tempos chorando, devido à angústia de não encontrar trabalho (no máximo, os homens choravam "de raiva"); mas o mais interessante foi que, ao final da entrevista, Lutemberg explicitou sua satisfação em ter conversado, dizendo que estava melhor e que era muito bom demonstrar o que sentia. Contei a ele, então, de minha preocupação em pedir as pessoas falarem de um assunto doloroso, e ele me assegurou que não havia nenhum problema, que mais importante era ter a oportunidade de conversar.

A narrativa de Lutemberg ajuda a pensar sobre o desencontro entre os sonhos relacionados à profissão e aquilo que é possível fazer, e ele então orienta suas estratégias equacionando a análise da situação do mercado de trabalho e a necessidade de cursar uma faculdade que reverta tão rapidamente quanto possível em um trabalho bem remunerado. Também contribuiu para pensar sobre o papel dos concursos públicos como horizonte de estabilidade, levantando aspectos importantes ligados à cultura do emprego. Finalmente, a narrativa de Lutemberg fala do sentimento de impotência resultante de não conseguir atualizar sua identidade de homem responsável pela manutenção da casa - ele é filho único e mora com a mãe (que, mesmo doente, ainda trabalha) e a avó (aposentada).

Um "realismo" precoce: a escolha da faculdade - Logo no início da entrevista, Lutemberg comentou sobre o início das aulas na faculdade, conferindo centralidade à experiência de estar novamente estudando. Essa imediata referência à faculdade recém iniciada é bastante significativa pois revela uma mudança na própria maneira de experimentar o desemprego: 
"fazem um ano e cinco meses que estou desempregado; estou fazendo faculdade de administração, com ênfase em finanças, estou procurando nessa área um estágio, qualquer coisa assim, só que está difícil. Primeiro ano ainda mais, o pessoal não quer nem saber, quer que a pessoa esteja pelo menos no segundo ou terceiro ano. Teve um tempo em que eu parei de procurar por que desanimou total, por que eu ia, o pessoal olhava nem na cara, pegava o currículo e "Ah bom. Qualquer coisa gente entra em contato". Aí, só de olhar na cara você percebia que a pessoa não tinha vontade de te ajudar. Com essa desmotivação assim, eu comecei a perder o ânimo de procurar, fiquei um tempo sem procurar, mais de um mês até, acho que foi até uns cinco meses que fiquei parado. Aí agora, voltando a estudar, estou motivado, estou procurando mais assim, estou indo atrás, estou precisando por que não agüento mais ficar em casa. Estou desesperado, de vez em quando bate o desespero de não fazer nada, sabe? Mesmo você estudando, você procura algo mais: o seu dinheiro, alguma coisa assim. Então, foi isso que me fez parar de procurar, mas agora estou de volta".

Ainda que a volta aos estudos não seja suficiente - Lutemberg oscila entre o ânimo, o cansaço por ficar em casa e o desespero por não fazer nada - parece haver claramente uma diferença entre as perspectivas que ele era capaz de enxergar antes de ingressar na faculdade e aquelas que hoje consegue vislumbrar. Do período anterior à interrupção na procura, ele se lembra do desânimo provocado pelas sucessivas buscas frustradas; além disso, ele fala do tom displicente utilizado pelos atendentes das agências, que mal o olhavam, pegavam o currículo e burocraticamente avisavam que entrariam em contato, se acontecesse qualquer coisa156. Quando volta a estudar, Lutemberg encontra novo

\footnotetext{
156 A impessoalidade que caracteriza as agências de emprego privadas apareceu em diversas das entrevistas que fiz. Os adultos demonstravam especial irritação com o atendimento recebido, pois percebiam que o preenchimento de fichas acabava se tornando inútil, pois logo de cara estavam os dados relacionados à idade e escolaridade, sua experiência ficando em segundo plano. Os jovens, por sua vez, não tendo conhecido outra maneira de procurar emprego, não teciam críticas diretamente ao modo de funcionamento e seleção, mas demonstravam desconfianças quanto aos critérios utilizados pois a experiência que tinham era que dessas buscas em agências nada resultava. O desânimo de Alessandra, vale lembrar, está bastante relacionado à falta de resposta, a despeito de todos os seus esforços. Parece-me que seria um importante tema de pesquisa compreender as relações entre a proliferação das agências de emprego e a insuficiência de um sistema de seguridade e recolocação profissional por parte do Estado, compreendendo também o sentido de todos os serviços ligados ao
} 
ânimo e também uma outra ordem de problemas: agora é preciso se preocupar com estágios, com o ingresso na própria área - para potencializar os efeitos de empregabilidade produzidos pelo ingresso numa faculdade - e também com o fato de alunos de primeiro ano terem menos chances de conseguir um trabalho, logo de cara, pois as empresas não estão preocupadas em ensinar ninguém a trabalhar157: "Gostaria até de trabalhar nessa região de Osasco, Barueri, ou na zona oeste de São Paulo, porque fica mais fácil no transporte, essas coisas. E também costuma ter umas empresas boas por aqui. Até que eu estou, tem bastante empresas que procuram nas área, mas só que eu acho que também é por causa do tempo da faculdade e eles querem uma pessoa que saiba mais, que tenha uma fluência maior no que está estudando; então, no primeiro semestre, começo de ano, você tem uma base, está começando, e você não sabe muita coisa. Você não sabe nada, quer dizer. Está entrando... então o pessoal já vê que, se por, vai ter que ensinar alguma coisa da firma, da área. Então acho que por isso que eles não pegam muito".

Comentando ainda sobre a faculdade, Lutemberg demonstrou surpresa por estar gostando tanto das matérias; perguntei a ele, então, se administração era o curso que ele sempre sonhara fazer, ao que ele me respondeu: "Era educação física o que queria fazer, mas como é uma área difícil de ganhar dinheiro e eu estou precisando para ajudar a minha família, então, eu vou fazer uma área que dê um pouco mais de dinheiro, que tem uma expectativa melhor e assim que eu puder, se tiver uma estabilização num serviço, posso até fazer só por gosto, quem sabe? Às vezes, nem faça, nem trabalhe na área, mas por gosto eu queria fazer. Agora eu vou até prestar outro vestibular, para ver seu passo em outra faculdade melhor". Essa objetividade na escolha profissional, abandonando a área de interesse a fim de ingressar numa área que possibilite um retorno mais rápido e certo (?) é um dado importante, revelador do sentido de responsabilidade que Lutemberg tem

desemprego - elaboração de currículos, preenchimento de fichas, páginas eletrônicas especializadas e mesmo os serviços prestados por sindicatos.

157 Trata-se, é preciso dizer, de uma percepção que encontra muitos indícios na realidade: a intensa rotatividade que caracteriza os empregos não estimula o investimento de mais longo prazo na qualificação da mão-de-obra, a despeito da circulação da idéia de que o "despreparo dos trabalhadores" é em grande parte responsável pelas altas taxas de desemprego; sobre as relações entre qualificação e flexibilidade, ver Troyano, 1991; Martins, 1997, Guimarães, 2004 e Leite, 1997. 
em relação à sua família. Suas escolhas, assim, não estão orientadas apenas por sua vontade ou por seu gosto, mas obedecem a uma necessidade mais geral, de corresponder ao papel de, como filho único, sustentar a casa ${ }^{158}$.

O ingresso na faculdade também é visto como um fator que dá novo ânimo à procura porque se trata também de mostrar "ao mundo" que se está lutando por desenvolver competências e construir um futuro: "Pode ter sido também porque você vê outros horizontes: comecei faculdade, às vezes dá um estalo em alguém para me dar um emprego, às vezes até conhecido: "Ah, você está fazendo faculdade? Estou precisando de alguém lá...", entendeu? Ajuda, a faculdade dá uma perspectiva melhor para você, por que se você estiver não estiver estudando eu acho que é até pior".

Impressiona notar quantas vezes Lutemberg utiliza imagens que permitem perceber que ele relaciona a faculdade à ampliação dos limites do possível expectativa, outros horizontes, perspectiva. Trata-se não apenas de construir merecimento pelo esforço demonstrado, mas também, como ele nota, de afirmar outra identidade ainda que na mesma teia de relações - "às vezes dá um estalo em alguém".

É interessante observar que Lutemberg havia feito curso técnico de processamento de dados durante o segundo grau, tendo vivido a experiência de procurar emprego na área, o que lhe permitiu observar alguns aspectos do mercado de trabalho: "E eu fiz curso técnico, fiz colegial técnico. (...) Processamento de dados. Aí depois eu fiz um curso técnico do Senac de telecomunicações; só que eu ia atrás de um emprego na área e quem estava na área estava se especializando, e quem não está eles pedem uma faculdade, eles pediam: "Não, você tem que fazer faculdade. Não preciso de técnico, técnico tem um monte aqui". Talvez essa experiência de não ter conseguido se inserir no mercado de trabalho, mesmo sendo portador de uma

\footnotetext{
158 A percepção de que se trata de escolher entre uma atividade que traria realização pessoal e outra vista como mais racional para a solução do problema imediato da sobrevivência é comum aos jovens e a escolha está informada pelas perspectivas que têm em relação a uma e outra atividade. Como já notei anteriormente, tal percepção está na origem de dois tipos diferentes de comportamento em relação ao trabalho: ou uma relação instrumental, que figura o trabalho como um sacrifício necessário e encontra em outras esferas os eixos de realização pessoal ou uma relação que põe o trabalho no centro das possibilidades de auto-realização (Bajoit e Franssen, 1997 e Chiesi e Martinelli, 1997).
} 
qualificação que deveria habilitá-lo a trabalhar, tenha ensinado Lutemberg a desconfiar da "pura e simples" aquisição de conhecimentos e qualificações como uma estratégia realmente viável para a consecução de um posto de trabalho ${ }^{159}$.

Ao contrário de Mário, que demonstra mais convicção de que os cursos que faz deveriam ser suficientes para que conseguisse um emprego e, desse modo, afirma que "não quer começar de baixo", Lutemberg demonstra uma visão de mais médio e longo prazo: "A experiência de alguém que é novo, não tem como ter; você está começando agora na carreira e tal. (...) Então, eu estou começando, por isso que estou precisando de estágio, para pegar essa experiência. Eu quero pelo menos um estágio para me dedicar bem, pegar os esquemas das empresas, como é a rotina, para tentar ser um bom profissional, para que um dia no futuro (eu entre) numa empresa melhor, um salário melhor, eu consiga entrar, entendeu?".

A despeito de suas experiências anteriores de trabalho, Lutemberg parece considerar que essa procura que está realizando agora, no momento após o ingresso na faculdade, é que consiste realmente no esforço para aprender uma profissão que lhe confira uma identidade de fato - os trabalhos anteriores eram necessários à sobrevivência, não lhe ofereciam horizontes de crescimento, como ele mesmo aponta quando comenta a perspectiva de futuro que tinha durante o período de desalento: "desde que eu comecei a trabalhar eu tenho estas perspectivas, tanto é que eu saí da Tramontina mais por causa disso também, porque lá eu sabia que seu ficasse, vai, porque eu entrei lá novo, fiquei um ano, se eu ficasse vinte anos, quinze anos, vinte anos eu ia ser a mesma coisa. Iam aumentar os salários só por causa dos reajustes, não ia ter perspectiva, porque muita gente lá estava assim. Eu até tentei dar conselho para o pessoal que não adiantava continuar fazendo isso, por que vai morrer

\footnotetext{
159 Seria necessário refletir melhor sobre a efetividade atual dos cursos técnicos de nível médio. Durante muito tempo, esses cursos foram vistos como uma formas de qualificação de mão-deobra e também porta de entrada para que os jovens tomarem parte no mercado de trabalho. Porém, como a experiência de Lutemberg mostra, essa situação tem se modificado a partir das exigências crescentes - a resposta recebida por Lutemberg é emblemática: "técnicos já tem um monte". Lembro também que o filho de Suely, que estava no último ano do curso técnico em telecomunicações, pretende começar a trabalhar tocando violão em churrascarias, com seu tio o que tanto pode significar uma opção pela atividade que possibilita realização pessoal quanto a antecipação das dificuldades que enfrentará ao tentar se inserir na área de formação.
} 
nisso, e tem de fazer uma coisa que melhora sua vida, que melhora sua profissão, que melhora tudo. Eu tinha essa idéia. Só que, quando você vai entrar no ramo, que está procurando, você vê que não é muito assim. Você está estudando, você tem as coisas e é difícil mesmo assim, entendeu? A concorrência é grande, não é só você que está estudando e não é só você que está fazendo as coisas: tem muita gente fazendo, e as vezes está fazendo um curso melhor, uma coisa melhor, e tem uma chance melhor. Mas fazer o que? Eu tenho oportunidade de fazer aqui, eu tento fazer aqui e tenho que segurar e abraçar e fazer".

Às perspectivas de melhoria, de encontrar um trabalho que seja satisfatório tanto do ponto de vista da remuneração quanto do ponto de vista pessoal, contrapõe-se a dura realidade: a concorrência para os postos mais qualificados é grande e fazer cursos ou uma faculdade não é suficiente; existem mecanismos que operam distinções no interior mesmo desse conjunto de trabalhadores que tem acesso à graus mais altos de escolarização. A percepção de Lutemberg, nesse sentido, é agudíssima: "estou fazendo a Faculdade X. Mas só que quando você procura emprego, eles olham para aonde você estuda. Se você está empregado, eles exigem faculdade: não importa aonde você faça, eles só querem que você tenha a faculdade. Mas quando você procura, eu acho que eles olham isso, estou querendo passar por uma faculdade melhor, pelo menos assim acho que vai melhorar também de eu arranjar um emprego melhor".

A distinção que ele faz sobre as necessidades de qualificação entre aqueles que já estão empregados e a mesma necessidade entre aqueles que estão à procura de um emprego é muito importante para iluminar os valores que estão operando no mercado de trabalho: daqueles que já estão inseridos, exige-se que demonstrem sua disposição em aprender mais para permanecer no mesmo lugar160, não tendo importância alguma a "marca" dos cursos que freqüentam, talvez até porque se reconheça que o cotidiano de trabalho já lhes tenha ensinado o necessário. A maior parte dos colegas de Lutemberg se constitui desses trabalhadores em busca de aumento da qualificação - "A maioria, pelo que percebi, porque eu não tenho muito (contato) porque é o primeiro ano e estou começando 
agora a ter uma amizade assim, percebi que todos trabalham. Dos que ficam meio em volta, todos trabalham. Pela faculdade, pelo preço, acho que a pessoa mais velha - não são tão novas assim - aí já tem... (...) O pessoal (é) mais velho, por exemplo, o serviço já está exigindo que ele faça faculdade, então percebi que é por ai".

Quanto àqueles que se candidatam ao início do trabalho, desses se pode exigir uma certificação constituída pela "marca" da faculdade ou do curso que fizeram pois a qualidade de sua aprendizagem só pode ser garantida com referência àquela marca. É nesse contexto que a encalacradela é experimentada, (e não é à toa que as falas dos jovens entrevistados dão noticias disso), pois o valor do trabalhador deixa de estar dado por sua disposição para o trabalho e passa, cada vez mais, a estar mediada pelo acesso a bens culturais consumíveis, entre eles a educação superior. Parece não haver mais espaços para a construção de trajetórias que não estejam limitadas pelas margens que o lugar social de origem conforma - como se o imaginário do esforço individual tivesse sido sucedido pelo imaginário das oportunidades disponíveis e da capacidade de aproveitá-las (lembre-se, ademais, que oportunidade significa "ocasião favorável, ensejo", o que aproxima o termo mais à sorte do que à sabedoria ou à virtude) ${ }^{161}$.

É com uma oportunidade que Lutemberg se vê obrigado a contar, a fim de constituir a trajetória que deseja - um estágio ou um emprego, alguma atividade no qual tenha a chance de mostrar quem é: "Você pode mostrar que vocêé um bom profissional, não por você estar fazendo uma faculdade que não tenha nome, mas por você mesmo, pela sua capacidade".

É nesse aspecto que as trajetórias relatadas neste capítulo levantam questões relacionadas às especificidades das relações de trabalho em nosso país, conduzindo-nos à reflexões que nos distanciam das interpretações de autores que pesquisam jovens europeus, pois a incerteza que estes jovens expressam não aparece carregada da ambigüidade que permitiria atribuir a ela o caráter de

\footnotetext{
${ }^{161}$ Nesse sentido, é bastante compreensível que os jovens entrevistados por Regina Magalhães de Souza não demonstrem muita confiança nos possíveis efeitos positivos de empregabilidade relacionados à conclusão do ensino médio ou nas possibilidades de ingressar numa faculdade pública. Souza atribui essa desconfiança, entre outros fatores, à "uma atitude de antecipação do fracasso" (Souza, 2003: 88).
} 
experimentação (Chiesi e Martinelli, 1997 e Schehr, 2000). A incerteza quanto ao futuro e às possibilidades de inserção aparecem como fonte de sofrimento, como algo que suspende o início da vida adulta e a assunção de responsabilidades; é a incerteza que os lança nesse presente vivido como "moratória", obrigando-os a esperar por uma oportunidade (um lance de sorte, um estalo em alguém...) que finalmente lhes dê a chance de mostrarem quem são.

Poder-se-ia argumentar que, vivendo situações de emprego recorrente, as gerações passadas - notadamente a população de baixa renda - também vivia sob o signo da incerteza. Porém, e é este deslocamento que acredito que se revela quando se procura refletir a partir do conjunto de valores que gravita em torno da cultura do emprego e da cultura do trabalho, o sentido da incerteza era diferente pois que não chegava a pôr em xeque as demais formas de experiência do tempo e do espaço. Como as narrativas dos jovens revelam, (e as incompreensões expressadas pelos adultos reiteram), a incerteza em relação ao trabalho desloca os significados deste, impulsiona à construção da identidade por outras vias, desorganiza as relações entre as gerações e coloca estes jovens numa zona liminar. Trata-se, porém, de uma liminaridade sem perspectivas de integração: a instabilidade e a incerteza são as novas condições "normais"162.

Se até aqui vim mostrando que a cultura do emprego inseriu a mobilidade ascendente e o planejamento da vida, ao menos no médio prazo, no horizonte de possibilidades, como compreender as perspectivas que têm os jovens que entram no mercado de trabalho num momento de crise dessa cultura? O que poderá resultar - em termos políticos - de gerações que estão sendo socializadas num ambiente em que instabilidade, precariedade e sobrevivência (aspectos que tão de perto se relacionam ao que vim chamando cultura do trabalho) são a regra e essas regras nem parecem amparadas por um horizonte de mobilidade? Se pensarmos, com Hannah Arendt, que o que caracteriza a mundanidade é a permanência, construída sobre medidas comuns e garantida pela existência de um espaço público que permita a emergência de novas 
medidas, como imaginar o futuro desses jovens para além da encalacradela na qual eles próprios reconhecem estarem entalados?

O emprego possível: os concursos públicos - As estratégias utilizadas por Lutemberg para procurar emprego são aquelas que já observei que são comuns aos jovens entrevistados, variando apenas o acesso à internet: "Sou inscrito no CIEE, vou lá todo dia, quase toda semana, aqui em Alphaville que é aqui perto, só que nunca têm vaga. Eu vejo no jornal, quando eu vou, na segunda-feira mesmo de manhã ou está ocupado ou já está em processo de seleção. Fiz cadastro naquele CATHO, da internet, mando bastante e-mail, só que não tem retorno".

O desgaste da procura - uma maratona - bem com a incerteza de conseguir um bom trabalho, acabaram levando Lutemberg a estudar para concursos públicos, na esperança de conseguir um emprego fixo e estável: "Aí, agora, encontrei uma menina (sua namorada) que está me apoiando para fazer concurso público. Ela falou que, eu acho também, que a melhor forma de arranjar emprego a num concurso, mas só que você tem que se dedicar, estudar, não adianta você só se inscrever, ir lá fazer a prova que vai passar. Aí estou me dedicando também nessa área, para passar no concurso público, que eu acho que pelo menos um serviço garantido, que a remuneração é boa e tudo mais. (...) É porque... você tem a segurança do emprego, que é difícil ser mandado embora, salário, a maioria são bons, principalmente para quem tem nível superior. Um monte de vantagens para funcionário público, então, eu tô pensando nesse lado".

É bastante interessante notar que, a despeito de Lutemberg fazer a crítica das estreitas perspectivas de desenvolvimento que percebia quando trabalhava na Tramontina e valorizar o comportamento de constante aprendizagem, ao enumerar as vantagens do funcionalismo público, todas elas se referem à estabilidade: garantia, boa remuneração, segurança e salário relacionado ao grau de instrução.

Ainda, é bastante interessante que, ao contrário de Suely, que valoriza o concurso público como estratégia de superação da barreira representada por certos atributos pessoais (ser mais velha, gorda ou mãe) e também diferente de 
Alessandra, que vê nos concursos uma saída difícil para superar a falta de uma rede de relações, Lutemberg está mais interessado na qualidade do emprego oferecido por meio dos concursos públicos.

De todo modo, o reinício da procura tem feito Lutemberg renovar suas esperanças e resistir ao desgaste provocados pelos constantes deslocamentos e pela falta de respostas: "Tipo, eu estou cansado porque é muito desgastante: você acorda cedo, para andar muito e não ter nada de retorno. Só que eu estou querendo, estou indo. Faz umas três semanas que estou assim, eu torço para tentar alguma coisa. Fico triste na hora que eu volto da maratona, mas vamos para frente, amanhã a gente tenta de novo, amanhã a gente consegue".

Essa atual resistência, porém, não foi uma constante durante o período de desemprego. Durante cinco meses Lutemberg ficou em casa, desanimado, angustiado por não encontrar trabalho mas também por perder de vista o horizonte de conseguir se inserir no mercado de trabalho; importa sublinhar, ainda, que a descrição que Lutemberg faz de sua situação atual é bastante parecida com a descrita por tantos entrevistados em situação de desemprego aberto: correria, constante caminhada ou maratona. Trata-se de movimento, de descrever o próprio esforço, acompanhando-o quase sempre da esperança de que "qualquer hora”, “amanhã”, ele seja recompensado.

O período de desalento - Durante os cinco meses que ficou em casa, Lutemberg ficava à toa, chorando ou trancado no quarto, sem querer conversar muito e paralisado pela angústia das buscas frustradas. Na origem de tal paralisia estava a sensação de não ter utilidade, de não responder ao que se espera dele: "O que me deixa angustiado em não encontrar um emprego, é por que você fica limitado, por exemplo, em casa você tem necessidade de ajudar sua mãe, minha avó, e eu não consigo. Aí eu fico angustiado, fico triste, fico pensando que não sirvo para nada, entendeu? Fico pensando que estou ali só para gastar o dinheiro deles, não ajudar eles. Minha mãe já está com uma certa idade, não consegue emprego também, eu nem quero que ela trabalhe mais, ela se sustenta só de pensão e aposentadoria. Minha avó a mesma coisa. Então, eu acho, como sou filho único, 
eu acho que deveria ter o papel de ajudar a minha família. Como não consigo, vem um monte de coisa, de besteira na minha cabeça, tipo angústia, ficar deprimido... você fica meio desolado assim não é?". Trata-se de uma sensação bastante parecida com a experimentada por Mário, que acaba se sentindo culpado pelos gastos que dá e, então, deseja desesperadamente trabalhar, não com o objetivo de se tornar independente dos pais mas para inverter sua posição dentro da família: ao invés de "um peso", uma ajuda. Essa vontade de contribuir/retribuir aos pais por tudo que lhe deram é bastante comum entre os jovens entrevistados, notadamente entre os de sexo masculino - o que pode nos indicar que a ética do provedor $^{163}$, centrada nas responsabilidades que se tem com a família, persistem a despeito do adiamento do momento do casamento.

Nessa época em que interrompeu a procura, Lutemberg acabou se afastando dos amigos, e restringiu seu círculo àquelas pessoas mais próximas: “converso com meus amigos mais íntimos, com minha namorada converso... (...) eles sabem como é a situação, entendem que não adianta ficar desse jeito, por que vai só atrasar. Cinco meses que fiquei assim meio desolado, já poderia ter arranjado um emprego, só que às vezes não adianta. Você precisa passar por isso, para ver que você tem condições, sei lá mostrar alguma coisa para você, entendeu. Às vezes você mesmo fala: "Não, eu tenho capacidade, não preciso ficar chorando, vou atrás e tal"". Note-se que Lutemberg acaba revelando nessa fala a impressão de que o período de desalento também poderia ser entendido como uma provação, cujo objetivo principal é encontrar forças internas e refazer a crença na própria capacidade que a reiterada frustração em encontrar trabalho havia minado.

A decisão de voltar a procurar se deveu tanto à restauração da crença na própria capacidade quanto à necessidade. Se as buscas não davam resultado, tampouco permanecer em casa daria e a vontade de ter seu próprio dinheiro, contribuir com as despesas e, não menos importante, começar a trabalhar, foram os fatores que o impulsionaram a voltar a procurar: "Sei lá, eu acho que foi um tempo, falta de dinheiro - por que às vezes você quer fazer alguma coisa, comprar

163 Cf. Zaluar, 1990. A ansiedade em começar a trabalhar, contribuindo assim com o orçamento doméstico, também pode ser entendida como vontade de corresponder às expectativas dos adultos - a narrativa de Mário ilustra tal situação. 
alguma coisa, ter alguma coisa, entendeu? - aí eu falei "Meu, se eu continuar aqui não vai adiantar nada, vou continuar não tendo nada, não vou ter meu dinheiro para sair, não vou ter dinheiro para comprar a minha roupa que eu quero, não vou ter dinheiro para ajudar a minha mãe, não vou ter dinheiro para nada então... se eu continuar aqui eu não vou ter nada, mas se eu sair, eu não tenho nada agora, mas daqui a pouco vou ter, entendeu? Não tenho dinheiro para ficar andando muito, mas o que dá para fazer eu gasto, e faço, agora. Mas quando eu estava (ruim), que estava triste eu pensei, acho que foi um pensamento meu mesmo que fez o mudar, vi que não ia adiantar nada eu ficar parado, então bola pra frente, vamos ver se dá. Pode demorar um pouco, mas eu sei que está difícil para todo mundo, tá difícil para mim, mas a gente consegue, um dia consegue. Quem sabe é hoje, lá embaixo assim, sei lá".

Em relação ao futuro, principalmente agora, tendo voltado a estudar, Lutemberg parece ter boas perspectivas: "Ah, que eu acho que dá para ter um futuro bom. Mas aí você tem se dedicar, não só fazer faculdade, tem que fazer especializações, cursos, palestras, que exige na área - em qualquer área, para você ser um bom profissional e ser requisitado no mercado. Então, se tiver capacidade e disposição para fazer, aí eu acho que vou ter um futuro promissor, dá até para até ganhar um salário bom, constituir família sem problema, aí dá para fazer. Não agora: daqui a uns dez, vinte, quinze anos dava para pensar nisso". O "futuro bom", no entanto, longe de estar assegurado, depende continuamente de esforço, investimento e paciência, pois os resultados (reconhecimento, estabilidade financeira) só serão colhidos no longo prazo.

Talvez essa seja a diferença principal entre a narrativa de Lutemberg e as outras narrativas expostas nesse capítulo. Ainda que seu desânimo tenha sido o mais paralisante, seus pés parecem estar fortemente colados ao chão - o que se expressa na escolha por um curso técnico de nível médio ou pela faculdade de administração ${ }^{164}$. Lutemberg procura desenhar uma trajetória profissional e, ao contrário de Mário, não se inquieta com o reconhecimento de que os resultados levarão tempo para serem alcançados. A razão de sua angústia, assim, está

\footnotetext{
164 Mais uma vez, esse "realismo" parece ser uma característica comum aos jovens que
} ingressam no mercado de trabalho nesse momento, cf. Chiesi e Martinelli, 1997: 112b. 
menos na demora em conquistar seus sonhos do que na consciência de que é preciso partir de algum lugar. É por isso que a primeira experiência na área assume tamanha importância: portador de um projeto profissional, não lhe é mais possível aceitar qualquer trabalho. Lutemberg agora precisa se inserir, o mais rapidamente possível, numa atividade relacionada à faculdade que faz.

Ele tem consciência de que a faculdade apenas lhe dará as bases e o "passaporte" para que ele possa começar a trabalhar: aprendizado do trabalho e a experiência, só será possível adquirir no próprio cotidiano de trabalho; daí sua urgência.

\section{IV - A vida é coisa séria - Rodolfo}

Rodolfo tem 20 anos. Concluiu o ensino médio e mora com os pais e uma irmã. Seu pai era metalúrgico, tendo se aposentado depois que a fábrica em que trabalhava faliu - "ele falava que se a COBRASMA não fechasse, ele estaria lá até hoje. Ele ia se aposentar e continuar lá" - e sua mãe não trabalha. Quando o entrevistei, ele estava desempregado há um ano e três meses.

Branco, alto, cabelos escuros e uma voz grave, Rodolfo é um pouco taciturno. A entrevista que fiz com ele foi em abril de 2003 e apenas à distância do tempo é que sua "seriedade" pôde emergir como uma característica fundamental. Rodolfo quase não sorriu e também não fez nenhum esforço para que nossa conversa se estendesse: não que ele estivesse desconfortável, mas sua atitude procurava deixar claro que aquele assunto - seu desemprego e sua procura por um trabalho - eram assuntos que mereciam todo o respeito, não deixando nenhum espaço para descontração.

A narrativa de Rodolfo fala da conformação dos sonhos às margens do que se apresenta como possível: ele queria ser piloto, mas acabou fazendo um curso de qualificação no Centro de Solidariedade que hoje o faz procurar por um emprego na área gráfica (a exemplo de Mário); além disso, não gostou do período que serviu o exército, por achar a disciplina muito estressante, mas tem se dedicado a estudar para concursos da Polícia Militar. O impressionante é que 
em nenhum momento Rodolfo pareceu acreditar que houvesse contradições em suas afirmações - para ele, trata-se de "encontrar um jeito" para começar a trabalhar, já que percebe que “o desemprego está muito ruim”.

Rodolfo conta seu tempo de desemprego tomando como referência a saída do exército: "Servi o exército durante um ano: eu fiquei lá, depois eu saí de lá porque me licenciei, aí fiz alguns cursos na área gráfica, não é? Tentando entrar no ramo mas faz um ano e três meses que estou desempregado, que não consigo arranjar uma vaga. (...) Só fiquei um mês fazendo os cursos e estou tentando achar uma vaga na área gráfica".

Antes de entrar no exército, a exemplo de Mário, trabalhou com o pai: "trabalhei durante seis anos com meu pai, de entregar a revista". Segundo relatou, depois de sair do exército, resolveu não voltar a trabalhar com o pai e ir procurar o seu caminho. Assim, fez o curso na área gráfica oferecido pelo Centro de Solidariedade e começou a procurar principalmente nessa área - embora tenha afirmado estar disposto a pegar o que aparecesse: “qualquer área, área que surgisse para mim, eu ia pegar".

Rodolfo credita as dificuldades que está enfrentando em encontrar emprego à natureza dos postos de trabalhos da área gráfica: "é muito difícil entrar nessa área. Eu acho que é por isso. (...) é difícil de entrar, mas também no dia em de eu entrar, vai ser difícil de sair. (...) Conheci algumas (pessoas durante o curso). Acho que elas estão na mesma situação que a minha. Fiz o curso no final do ano aqui em dezembro e devem estar na mesma situação, procurando emprego". Em nenhum momento ele questiona a qualidade ou a importância do curso de qualificação feito: assim como Mário, parece confiar que o curso lhe confere um novo estatuto ante o mercado de trabalho e também uma identidade profissional. Rodolfo está pensando em se estabelecer nessa área simplesmente por ter feito um breve curso e é difícil deixar de notar como as trajetórias desses jovens vão se definindo menos a partir de escolhas do que das oportunidades que se lhes $\operatorname{apresentam}^{165}$. 
Perguntei a Rodolfo se, antes de fazer o curso, ele pensava em trabalhar na área gráfica e ele me respondeu: "é algo que eu gosto, não é? Outro ramo um que eu também queria ser piloto, piloto de helicóptero. Mas para tirar a carta de piloto e é muito caro, não é a minha situação... aí estou tentando ou uma outra área, que a área gráfica pra mim é mais fácil".

A característica de ir seguindo o curso que a vida vai desenhando, conforme as oportunidades que se apresentam como possíveis, aparece ainda em outro momento do relato de Rodolfo, quando ele fala sobre seu período de desalento: "Eu fiquei por dois meses e meio no meio do ano passado, sem procurar. Estava muito estressado mesmo do exército, até conversei com meu pai: "Vou parar um pouco de procurar emprego, vou fazer uns cursos para ver se minha cabeça melhora, depois de terminar os cursos eu vou procurar emprego de novo"". Ele aponta com razões para seu estresse à disciplina do exército, ao desgaste provocado pela procura infrutífera e também pelo esforço de estudar para prestar concurso e entrar na... Polícia Militar.

Mesmo não tendo gostado da experiência no exército - "...O regime lá dentro é muito fechado" - quando saiu de lá, a única saída que enxergou foi prestar concurso e entrar na PM: "Aí eu fiquei meio sem saber, fiquei de janeiro até mais ou menos setembro, pretendendo entrar na PM, prestei vários exames na PM. Ai, peguei, chegou em agosto começou a me estressar bastante e aí eu parei de procurar emprego". Perguntei como ele iria conciliar o seu pouco apreço pela disciplina militar e o trabalho na Polícia Militar e ele me disse que "Mesmo não gostando muito, eu estava entrando. Por que o desemprego está muito ruim então eu estava tentando. O salário lá dentro é bom".

Rodolfo resolveu prestar os concursos, assim, procurando alguma alternativa que lhe permitisse escapar do desemprego. Aliás, ele também disse que teria permanecido no exército, seguindo carreira militar; o que o desmotivou foi o fato de que sua carteira ficaria sem nenhum registro, complicando sua situação quando deixasse o exército: "Carteira assinada é tudo em branco. Carteira de militar é branca. Senão, se eles assinassem minha carteira no exército, eu estava lá. Porque estava pensando em ficar lá, nove ano; (mas) sair com 28 
anos, com a carteira branca, ai minha situação ia piorar. Eu com vinte anos não encontro emprego...".

Nessa trajetória truncada, cheia de "acidentes" de percurso, revela-se a desorientação de Rodolfo, que parece ser levado de um lado para o outro conforme o sabor das possibilidades que enxerga: antes de fazer o curso na área gráfica, estava prestando concurso para PM; depois do curso, passou a procurar na área gráfica, embora ainda se disponha a aceitar o que aparecer.

Diferente dos outros jovens, Rodolfo não declarou se sentir pressionado pelos pais ou angustiado por dar despesas em casa, o que não significa que o longo período de desemprego não seja uma fonte de preocupação. Quando perguntei a ele o que esperava que mudasse em sua vida depois que conseguisse um emprego, ele me respondeu imediatamente: "Ah, eu só não quero que chegue um tempo em que eles me mandem embora, porque aí eu vou estar na mesma situação que estou hoje"166.

Por outro lado, seu objetivo ao começar a trabalhar se aproxima bastante daquele expresso por Mário e Lutemberg: “(quero entrar numa empresa pensando) Em ficar um certo tempo, um bom tempo, até eu fazer uma faculdade, me formar...na área gráfica também. (...) Uns 7,8 anos (é um bom tempo para ficar no mesmo emprego). Até eu estabilizar na faculdade, acabar a faculdade". Assim, começar a trabalhar também se apresenta como a condição necessária ao aumento da

166 Comentando os resultados de uma pesquisa feita pela Datafolha, que procurava compreender qual o lugar que as pessoas conferiam ao trabalho frente a outras dimensões da vida (tais como "amor", "sexo", "família" e "lazer"), Nadya Guimarães observou que o trabalho aparece a frente de muitas delas (variando conforme critérios de gênero e cor), a não ser pela família, que aparece como a dimensão mais importante. Mas o mais interessante foi a resposta dada pelas pessoas entrevistadas quando perguntadas sobre o que primeiro lhes vinha à mente quando pensavam em trabalho: a imagem mais freqüente era a "do desemprego, da falta de trabalho, da necessidade de vir a conseguir um emprego", que aparecia três vezes mais do que outras como "rendimentos", "melhoria de vida" ou "realização" (Guimarães, 2003). A associação entre trabalho e desemprego não parece fora de propósito quando observamos a circulação de noticias sobre as (crescentes) altas taxas de desemprego ou sobre as progressivas exigências feitas àqueles que desejam entrar no mercado de trabalho. De fato, o desemprego se torna uma preocupação central, principalmente porque fica cada vez mais difícil distinguir entre aqueles que estão mais ou menos sujeitos a experimentá-lo: ele parece atingir a todos indiscriminadamente. E mesmo que isso não seja a verdade completa, seu efeito simbólico é bastante eficaz, o que a resposta das pessoas entrevistadas pelo Datafolha expressa de forma clara. 
escolarização e a construção da possibilidade de se estabilizar num emprego, numa profissão.

Quanto às expectativas que Rodolfo tem em relação ao início do trabalho, ele diz: "Eu espero entrar na área, não é? Conseguir um emprego bom para eu fazer uma faculdade. Eu vou ter as minhas coisas, não vou depender da minha mãe, eu vou ajudar a minha mãe e meu pai, pagando alguma coisa, pagando a conta de luz, água. Guardar um dinheiro para o futuro". Mais uma vez, é de independência, contribuição com o orçamento doméstico, constituição de identidade profissional e construção de garantias para o futuro que se trata.

Tomando as quatro narrativas expostas neste capítulo, o que mais chama a atenção é a aparente falta de perspectiva crítica em relação aos processos do mercado de trabalho postos em funcionamento. Se sublinho que se trata de uma falta aparente é porque todos os jovens aqui apresentados demonstram conhecer "como as coisas funcionam": são capazes de identificar os valores que estão postos em circulação, observam suas próprias possibilidades e se comportam de modo coerente com o diagnóstico que fazem do presente.

Entretanto, a falta de perspectiva crítica manifesta-se na consciência de que pouco pode ser feito por eles próprios a fim de modificar essa "ordem de coisas". A não ser pela construção de atitudes pessoais - constante aprendizado, disposição para aprender, adaptação à incerteza, manutenção da auto-estima, confiança em si mesmos, entre outros atributos que circulam como sendo os mais importantes para um "empregador ideal"167- nada mais parece estar ao alcance de sua governabilidade e é a isso que estou chamando de aparente falta de perspectivas: eles sonham, porém seus sonhos sempre estão condicionados por um "mas"; vão-se conformando no percurso de suas vidas, conformando seus sonhos, expectativas e esperanças entre as margens das condições que

\footnotetext{
167 A proliferação de livros de auto-ajuda que ensinam a se manter no trabalho ou a procurar um novo emprego de maneira eficiente - sempre atendendo às expectativas dos empregadores - nos dá uma importante notícia sobre novas práticas normalizadoras, que constroem a imagem do "trabalhador ideal" incluindo não apenas os comportamentos que deve demonstrar, mas também como deve se sentir e quais atitudes deve ter perante a vida e as dificuldades. Ver, como exemplo, o "manual" donde extraí o trecho que serve de epígrafe a este capítulo, "As cinco melhores maneiras de se conseguir um emprego", de Richard N. Bolles.
} 
estão dadas desde seu ponto de partida ou, então, contam com a sorte para modificar suas possibilidades.

O que se evidencia nessas trajetórias é que os caminhos que os conduzem até a vida adulta não têm trilhos - a trajetória não pode ser planejada mas vai se construindo à medida em que se vai vivendo. Além disso, como há um desencontro entre a amplitude das possibilidades existentes e a estreiteza daquelas que realmente aparecem como viáveis ${ }^{168}$, o conflito vivido se expressa sob a forma ou da raiva (Mário) ou da tristeza e do cansaço (Alessandra e Lutemberg) ou da resignação (Rodolfo).

Tais mudanças podem levar a imaginar que, se antes tínhamos a disciplina do trabalho como o valor moral operante da distinção entre trabalhadores e vadios, hoje talvez seja possível dizer que, para essa geração que entra no mercado de trabalho (e que recusa aquela disciplina do trabalho que Fátima tão bem descreveu como "vestir a camisa") tem-se na resiliência169 o principal valor moral, capaz de distinguir entre os que merecem e entre os que não merecem

\footnotetext{
168 Esse desencontro foi percebido também por Inês Caetano, em relação aos jovens que entrevistou: "A complexidade da realidade contemporânea realmente possibilita a criação de oportunidades, antes inimagináveis. A elevada escolaridade dos jovens em relação aos pais é um fato, o acesso a informações que ampliam as fronteiras do mundo, que integram os jovens a realidades mais amplas é incontestável, assim como as oportunidades que são criadas na esteira das novas desigualdades", (Caetano, 2004: 451). Porém, enquanto alguns jovens logram acesso a tais oportunidades (como a autora nota, principalmente aqueles que desenvolvem a habilidade de circular e interagir em diversos espaços sem que se reconheça sua origem), outros conformam-se a trabalhos precários, destituídos de sentido e incompatíveis com a escolaridade que alcançaram.

$169 \mathrm{O}$ termo resiliência, originariamente utilizado pela mecânica para designar a capacidade de um material para absorver repetidos choques sem deformar-se, começou a ser empregado no campo da psiquiatria para caracterização de determinadas capacidades psíquicas no início dos anos 90. Suzanna Sochaczewski (1998) relata, em sua tese de doutorado, ter ouvido pela primeira vez o termo, referido às características desejadas pelo empregador, no final dos anos 90, em um Programa de Capacitação de Dirigentes e Assessores Sindicais. Conforme seu relato, o termo foi empregado designando uma das virtudes necessárias ao trabalhador para sobreviver em tempos nos quais a crise se torna condição de vida. Encontrei alguns textos, principalmente relacionados à área de Educação, que se preocupam com a identificação dos atributos que tornam alguém resiliente ou não, tendo como objetivo refletir sobre práticas que poderiam fortalecer tais características em crianças e jovens. Não pretendo entrar em toda esta discussão conceitual - complicada pelos valores e alternativas que põe em cena, de alguma forma legitimando uma maneira de pensar que individualiza trajetórias e as possibilidades de sobrevivência moral frente às adversidades. Mantive o uso do termo, conforme a definição da mecânica, porque ele me parece adequado para sublinhar que se trata de valorizar a "natureza individual" de sobrevivência em contexto de insegurança, absorvendo os impactos de procuras frustradas ou longos períodos de desemprego ao mesmo tempo sem pôr em xeque os valores e a forma atual de organização social.
} 
ter o estatuto de empregado - superando as dificuldades originais e procurando se manter no estreito mercado de trabalho por meio de suas próprias qualidade individuais, sem chegar a pôr em questão a organização social que produz as inseguranças e desigualdades. É uma qualidade moral perfeitamente conformada à idéia de que "muitos serão os chamados e poucos os escolhidos".

Se esta interpretação tem sentido, não espanta que a construção do merecimento seja tão importante quando a construção da empregabilidade, pois para além dos atributos tais como escolaridade, experiência e qualificação, também são necessárias algumas atitudes morais - diferentes da disposição para o trabalho e a disciplina - relacionadas à adaptação a uma vida de incertezas. A resiliência aparece, assim, como a capacidade de persistência, a despeito das dificuldades; como uma expressão da solidez de caráter, afirmada pela capacidade de, internamente, conciliar todas as contradições e manter-se firme, assumindo a responsabilidade pela própria trajetória ${ }^{170}$.

\footnotetext{
170 A reflexão sobre os novos desafios que se colocam para a constituição do caráter uma vez que à instabilidade e à incerteza do presente não se contrapõe o horizonte de superação da crise (pois o sentido do presente está justamente na afirmação dessas características como condição "normal") é tratada de maneira sensível e fecunda por Richard Sennett (Sennett, 2004).
} 


\section{COMENTÁRIOS FINAIS}

"Não se sabe ainda se o mundo acabou realmente no sábado, como fora anunciado. Pode ser que sim, e não seria a primeira vez que isso acontece. A falta de sinais estrondosos e visíveis não é prova bastante da continuação. Muitas vezes o mundo acaba em silêncio, ou fazendo um barulho leve de folha. Tempos depois é que se percebe, mas já então vivemos em outro mundo, com sua estrutura e seus regulamentos próprios, $e$ ninguém leva lenço aos olhos pelo falecido". (Carlos Drummond de Andrade)

\section{Entre o desalento e a invenção: de tudo, fica um pouco?}

Antes de mais nada, é preciso explicitar o desconforto com a idéia de tecer "comentários finais". O que causa desconforto nem é tanto a palavra "comentários" - que nomeia, segundo o dicionário, "um conjunto de observações, esclarecedoras ou críticas, sobre quaisquer assuntos"171. A fonte principal do incômodo se refere ao adjetivo "final", que carrega esta última parte da dissertação com o peso de, ao menos provisoriamente, encerrar um percurso reflexivo.

O trabalho de pesquisa traz consigo um bocado de prazer e também de risco. Prazer, porque no desenvolvimento da pesquisa, temos a oportunidade de descobrir muitos outros prismas a partir dos quais interpretar a realidade. Risco, porque as descobertas não vêm organizadas, não se revelam no interior de um "todo coerente" e, por isso, constantemente nos lançam em direção a novos caminhos e questões. Havendo vontade, pode-se ficar por toda a vida nesse trabalho de ir retirando questões do interior de outras.

Desse modo, a existência de prazos, relatórios e rituais (tais como a defesa de uma dissertação) interrompem esse que é, conforme a lição weberiana, um percurso infinito, obrigando a organizar as descobertas e permitir sua partilha.

171 Dicionário Michaelis, CD-ROM. 
Ao escrever esta dissertação, estive sempre ciente do risco de me perder por entre o imenso conjunto de questões que o trabalho de pesquisa me propôs. O esforço realizado pela escrita, então, foi o de estruturar os achados de campo em torno das principais "regiões imantadas" que ocuparam minha reflexão, quais sejam, a compreensão do sentido que as mudanças que ocorrem no mundo do trabalho assumem para a vida das pessoas que experimentam o desemprego oculto pelo desalento e a compreensão do sentido que a mudança nas relações entre as pessoas e o trabalho assume para a vida da sociedade. Ainda que sejam "apenas" duas, não é difícil perceber que se tratam de questões suficientemente amplas, que não admitem um tratamento simples.

A despeito das imaturidades e de algumas dificuldades interpretativas mais evidentes, acredito que os achados que permeiam este trabalho estabelecem um ponto de partida para que muitos diálogos possam ser estabelecidos.

O primeiro ponto que deve ser sublinhado é que o quadro desenhado por tudo o que foi exposto revela e reforça a complexidade da questão do desemprego ${ }^{172}$. Tomei como ponto de partida para a reflexão uma categoria elaborada no intuito de nomear uma situação que, por ser heterogênea em

\footnotetext{
172 José de Souza Martins, respondendo à pergunta proposta pela Revista de Estudos Avançados "Que fazer para gerar empregos no Brasil?", vincula a questão à necessidade de compreensão das diferentes formas de desemprego: "Antes de ter uma fórmula de geração de emprego é prioritário um diagnóstico correto, objetivo e desapaixonado da situação crítica que leva ao desemprego. E disso, infelizmente, não dispomos. Para começar, deveríamos falar em 'desempregos' e não em desemprego, como se fosse tudo a mesma coisa. Temos três tipos de desemprego no Brasil e cada um deveria ser considerado separadamente. O primeiro éo desemprego herdado do passado, conseqüências das transformações na agricultura, não necessariamente transformações para melhor, para novos padrões tecnológicos. Transformações e crises específicas de determinados setores da economia. Na Zona da Mata Sul, de Pernambuco, clássica região da cana-de-açúcar, há alguns anos havia duzentos mil trabalhadores rurais. Agora há apenas quarenta mil. A maioria migrou para outros lugares, especialmente São Paulo. Dai resulta o desempregado cujo respectivo setor produtivo desapareceu. Por força de sua geralmente precária ou nenhuma escolarização, esse desempregado, em princípio, já não tem alternativas a não ser a melancólica inserção no Fome Zero. O segundo é o desemprego industrial que vem sendo produzido na atual conjuntura econômica, decorrente sobretudo da modernização, inevitável. Mas há, além disso, a concorrência de produtos importados de países cuja produção industrial se baseia na superexploração da força de trabalho, com trabalhadores ganhando salários ridículos, aquém das necessidades humanas. (...) Mesmo qualificado, esse trabalhador que a importação desemprega não terá chance fácil de reinserção no mercado de trabalho, a não ser abrindo mão de substancial parte de sua qualidade de vida. O terceiro é o desemprego prospectivo das novas gerações, o tema menos discutido, menos conhecido e menos abordado. Nossas melhores escolas superiores estão hoje diplomando desempregados", (J. de S. Martins, 2004: 3056).
} 
relação à norma, resta socialmente "invisível", ocultada sob outras realidades. Assim, o esforço da PED para identificar e mensurar o "desemprego oculto" representa uma grande contribuição para a compreensão do problema do desemprego ${ }^{173}$. O esforço de conhecer aqueles para quem a questão do direito ao trabalho não parece ser socialmente reconhecido ${ }^{174}$ amplia as fronteiras das situações de privação do emprego que a categoria "desemprego" permite revelar.

O que a pesquisa de campo me ensinou foi que, no interior mesmo de tais situações heterogêneas, o que há é mais heterogeneidade: o desalento não se explica, como se poderia supor com base nos dados explorados no capítulo 1, unicamente em termos de atributos pessoais (tais como sexo, idade ou escolaridade). A complexidade é tamanha que explicações (pelo menos aquelas capazes de iluminar o presente) só se encontram no exame das trajetórias e na escuta atenta das representações sociais que informam a desistência da procura $^{175}$. Isso significa reconhecer a necessidade de interrogar os aspectos que a categoria "desemprego oculto pelo desalento" é capaz de revelar hoje - pois creio que ela contribui para revelar uma dinâmica diferente de inserção/exclusão em relação ao momento no qual foi desenhada. E isso acontece porque as próprias noções de inserção se modificam como resultado de mudanças profundas e velozes nos mundos do trabalho: quem são aqueles que constituem, hoje, o "núcleo duro" do emprego? Como definir a privação

\footnotetext{
173 Como a Prof. Nadya A. Guimarães chamou diversas vezes a atenção, durante o curso de pósgraduação "Sociologia do Desemprego", a rigor, nunca tivemos na sociologia brasileira, um "problema de desemprego"; antes, tínhamos um "problema de emprego", de geração de postos de trabalho com qualidade, desfazendo a distância entre os ocupados nos setores "modernos" e produtivos da economia e aqueles ocupados nos setores "atrasados" (conforme a interpretação presente nos estudos sobre desenvolvimento e marginalidade).

174 Tenho em mente, em relação especificamente ao "desemprego oculto pelo desalento", as mulheres casadas e os jovens pois embora "o trabalho feminino" e o "trabalho do jovem" (notadamente "o problema do primeiro emprego") estejam formulados como um dos lados da "questão social", ainda assim tais problemas não parecem assentados sobre as mesmas bases de legitimidade que se confere àqueles que compõem o 'núcleo duro' do desemprego, como as falas dos entrevistados (principalmente José, Suely e Mário) revelaram.

175 É claro que a dimensão subjetiva, unicamente, também não é capaz de revelar satisfatoriamente a questão. Sobre as diferentes abordagens e metodologias e como contribuem para a elucidação de diferentes aspectos relacionados ao desemprego, ver Guimarães, 2004b.
} 
em relação ao direito ao trabalho se nem conseguimos dar conta de definir/entender as novas formas de trabalho?

Trata-se de compreender os deslocamentos das categorias cognitivas a partir das quais organizamos nosso conhecimento sobre o mundo do trabalho. Até aqui, nenhuma novidade: não é de agora que diversos autores vêm lidando com a necessidade de reinventar os termos a partir dos quais pensamos as relações sociais que se tecem a partir do trabalho ${ }^{176}$. O desafio que procurei enfrentar foi o de conhecer as reformulações desses termos que ocorrem no espaço e no tempo da vida cotidiana dos indivíduos. E enfrentei tal desafio tendo como matéria de reflexão o conhecimento produzido a partir da sensibilidade sociológica de quem experimenta o desemprego oculto pelo desalento ${ }^{177}$.

Como afirmei na introdução, em torno da questão dos significados assumidos pelas mudanças na vida das pessoas gravita a discussão sobre cultura do emprego e cultura do trabalho, ambas entendidas como estruturas cognitivas que dão sentido à vida cotidiana e permitem a compreensão do presente (bem como suas relações com o passado e o futuro).

Foi essa a razão que me levou a tentar olhar o problema a partir de um lugar de "desordem": queria compreender os significados do trabalho e, para isso, procurei por aqueles que estão duplamente apartados do mundo do trabalho - os desempregados por desalento. Interessava-me conhecer os pontos nos quais eles equilibram suas identidades, à diferença de empregados ou trabalhadores. Não que tivesse como hipótese que eles vivem num mundo organizado a partir de outros referenciais; ao contrário, acreditava que suas histórias de trabalho e suas representações - elaboradas a partir do afastamento

\footnotetext{
176 Ver Gorz, (1982, 1995, 2003), Dowbor (2001), Beck (1999) e Friot, (2001).

177 Tal modo de formular a questão, bem como o cuidado com os sentidos construídos pelo desempregado/informante é lição ensinada por José de Souza Martins: “ (...) o desemprego opera como revelador e analisador, no sentido lefebriano, do que é a sociedade neste momento e, portanto, desse e outros problemas e contradições sociais. (...) Os possiveis se revelam aí e os limites, as barreiras. $O$ desempregado, por sua liminaridade, numa pesquisa deste tipo, não entra apenas como informante. Ele entra, também como consciência crítica de limites e possibilidades, como analisador do que é a sociedade. Nessa perspectiva, é possivel compreender o que a sociedade é neste momento. Não simplesmente o que é no julgamento moral de sua vítima. Mas, sobretudo o que ela é a partir da sensibilidade sociológica da vítima (...), (Martins, 1998: 7).
} 
involuntário e prolongado do mercado de trabalho - seriam importantes para iluminar o que anda a acontecer no mundo do trabalho organizado, cuja organização e dinâmica já há algum tempo deixamos de compreender inteiramente.

A maneira de formular o problema, desde o início, traía que já então eu arriscava algumas interpretações. Propus a pesquisa tendo como referência termos como cultura do emprego $\mathrm{x}$ cultura do trabalho e também o termo enraizamento pois que se trata de pensar como se dá a construção/manutenção da identidade do trabalhador que se vê afastado do mercado de trabalho por um período longo, sem perspectivas de retorno a curto prazo. Essa forma de pensar significa, é claro, conferir ao trabalho centralidade na vida dos indivíduos, donde deriva a importância simbólica do vínculo que se estabelece com o trabalho e dos significados a ele atribuídos. No fundo, as perguntas latentes eram: se a identidade não se estrutura pelo trabalho, por onde ela se estrutura, se é que se estrutura? Por onde pode se estruturar (e esta pergunta é a que justifica a insistência em pensar os espaços de invenção)?

É custoso tecer considerações gerais que possam dar conta de fazer confluir as trajetórias de José, Fátima, Suely, Mário, Alessandra, Lutemberg e Rodolfo: nesse sentido, os significados que as mudanças no mundo do trabalho assumem em suas vidas são bastante distintos entre si. Mas apenas apontar a heterogeneidade não é suficiente para recolher os significados contidos nas narrativas destas pessoas; ao contrário - se me contentasse com isso, estaria conferindo a eles um olhar condescendente, individualizando suas trajetórias como se fossem resultantes apenas de suas escolhas pessoais. Não é disso que se trata.

Ainda que diferentes entre si, as trajetórias e as representações sociais que estruturam o fio narrativo a partir do qual são contadas as histórias são reveladoras do mundo em que vivemos e da maneira pelas quis as mudanças estão sendo elaboradas ${ }^{178}$. Nas narrativas analisadas nesta dissertação, a relação

\footnotetext{
178 A importância do fio narrativo a partir do qual se conta a própria história aparece bastante claramente em Richard Sennett, analisando os significados dos deslocamentos na narrativa de
} 
entre as representações sociais e a estrutura narrativa é o instrumento que permite penetrar a realidade de maneira mais pungente, pois que aqueles que têm suas histórias contadas aqui estão postos numa situação de liminaridade, o que aumenta sua sensibilidade para o reconhecimento dos limites e possibilidades que estão postos em cena, no presente.

E aqui chegamos a um segundo conjunto de aspectos que vale a pena distinguir: as figurações de emprego e de trabalho que afloram das narrativas analisadas.

Como fui apontando ao longo dos capítulos, parece-me que as características que enfeixei sob o termo "cultura do trabalho" tem muitas relações com aquilo que se tem chamado de "ética do provedor" (Telles, 2001; Zaluar, 1990) e, também, com a noção arendtiana de labor. Isto se deve, principalmente, ao fato de que, entre nós, essa cultura do trabalho se apresenta com o duplo caráter de revelar ao mesmo tempo uma privação e uma estratégia de constituição identitária.

A cultura do trabalho, desse modo, resulta da maneira por meio da qual as relações assalariadas assentadas sobre a forma de emprego se instalaram entre nós, operando uma distinção entre os pobres e os trabalhadores, conferindo aos últimos o estatuto de cidadãos e lançando aqueles que estavam excluídos do vinculo empregatício na indistinção da pobreza (cf. Telles, 2001). A cultura do trabalho revela o conjunto de esforços práticos e morais realizados para que a identificação com o universo da ordem seja mantida, operando uma nova distinção, desta vez no interior mesmo da pobreza, entre os pobres honestos $e$ trabalhadores e os vadios ou marginais.

Essa distinção, como as falas dos entrevistados mostram, não deixam de operar a despeito da generalização da crise do trabalho e do novo embaralhamento das situações ocupacionais; e ela está presente tanto nas falas

demitidos da IBM, no longo processo de elaboração da experiência de demissão (Sennett, 2004: 146 a 162). Acompanhando as diferentes maneiras de contar a história da demissão, ao longo do tempo, Sennett é capaz de compreender os significados mais profundos das mudanças tanto em relação às conseqüências sobre a constituição do caráter pessoal quanto em relação às possibilidades e limites que se colocam à ação política. 
de quem se auto-define como pobre quanto daqueles que se colocam fora da pobreza - partícipes dos valores de uma "classe média simples". Não à toa, em todas as falas apareceu claramente a recusa ao mundo da rua: desde José (que não sai de casa a não ser para caminhar pela manhã), passando por Suely (que pensa sua casa como espaço de intimidade e preservação) e chegando à Mário, (que credita seu comportamento tenaz para alcançar uma posição melhor à firmeza da educação que recebeu dos pais, que "souberam educá-lo dentro de casa").

Esses "outros" do trabalhador pobre esclarecem muito sobre os valores que informam a cultura do trabalho. E a oposição ao mundo da rua, bem como o cuidado com a casa, aparecem como traços importante no que revelam sobre o modo privado de lidar com as adversidades: "Esse reconhecer e fazer reconhecerse como sujeito moral dotado de discernimento nas escolhas feitas em uma trajetória de vida ordenada entre o trabalho e a família parece se determinar entre a percepção das fatalidades da pobreza e a crença em uma esfera de autonomia em que os indivíduos podem fazer frente às condições adversas que levam gente tão próxima e igual para o caminho do "ganho fácil" do crime. (...) Os "pobres-de-tudo" são os favelados e os que não têm um lugar fixo onde ancorar suas vidas, os que não conseguem emprego regular e vivem à deriva das circunstâncias e dos acasos da vida. Diante desses deserdados da sorte, os 'pobres honestos' se percebem como sujeitos que souberam vencer as adversidades da vida através do trabalho regular, da persistência e da coragem, que foram capazes, 'apesar da pobreza', de garantir uma dignidade para suas vidas através da família unida, da casa limpa e bem cuidada, da boa aparência e da cordialidade de seus comportamentos. Símbolos de uma vida digna e 'bem-sucedida', símbolos que constroem a figura do 'pobre porém honesto', casa e família montam um universo moral no qual a 'rua', lugar dos que vivem sem eira nem beira, é percebida como espaço da desordem moral, da família desunida, da sujeira, da violência e do crime, no que traduzem a seu modo a associação entre pobreza, desordem moral e violência", (Telles, 2001: 83; grifos meus). A cultura do trabalho aparece, então, como as práticas e os valores que tornam possível a identificação com o mundo da ordem e também como a maneira pela qual os indivíduos logram manter alguma autonomia 
sobre seu destino: pensando nestes termos, há uma escolha a ser feita e o valor moral do indivíduo se revela em persistir em sua adesão aos valores do trabalho, a despeito das adversidades enfrentadas ${ }^{179}$.

Os termos em que procurei pensar sobre a cultura do trabalho também a aproxima da noção arendtiana de labor ${ }^{180}$, ou seja, o trabalho realizado que se consome no próprio fazer. A noção é importante porque revela algo sobre as possibilidades políticas que estão abertas quando esta cultura do trabalho passa a ser a principal mediação entre os indivíduos e o trabalho, e quando os indivíduos estruturam sua identidade a partir de termos e lugares privados. Como a narrativa de José esclarece, as inserções precárias, se por um lado possibilitam a atualização constante da identificação ao universo de valores da "pobreza laboriosa"181, não são suficientes para a constituição de algo mais permanente - por isso chega-se ao final de uma vida de trabalho sem profissão, sem aposentadoria, sem nenhuma referência mais estável que permitisse a José referir sua situação de desemprego a algo menos privado do que as escolhas que fez ao longo de sua trajetória.

Se formos pensar com Hannah Arendt, para quem a possibilidade de ação (e, portanto, de política) relaciona-se à independência em relação à esfera da reprodução e da sobrevivência, quais possibilidades de ação podem estar postas quando os indivíduos estão sendo "devolvidos" à um modo de vida caracterizado pela incerteza e pela instabilidade (ou já estão sendo socializados

\footnotetext{
179 É muito interessante perceber como esta questão da escolha aparece nas falas dos entrevistados. Gilberto ( 37 anos e, na ocasião da entrevista, desempregado há 3 anos e 4 meses), por exemplo, contando sobre as principais dificuldades de estar desempregado e morando em São Paulo, relatou o seguinte: "porque você paga aluguel; eu tô com uma conta de luz que vai vencer...Setenta reais. Aí vem a luz, vem o alimento, vem as coisas que tem que ter dentro de casa, entra num ciclo de desespero. Tem até nego que chama pra fazer besteira. É isso que eu to te falando, se você não ta com a cabeça boa, você vai. E eu assisto demais o Repórter Cidadão e o Cidade Alerta, gosto...". Gilberto confere a esses programas o significado de instrução, como se eles fossem rememoradores de valores que, precariamente assegurados quando se está trabalhando, se encontram arriscados no momento de desemprego. Sobre o caráter e o papel destes programas, ver o interessante trabalho de Maria Thereza Costa, que trata do programa Gil Gomes (Costa, 1992).

180 "O labor é atividade humana que corresponde ao processo biológico do corpo humano, cujos crescimento espontâneo, metabolismo e eventual declínio têm a ver com as necessidades vitais produzidas e introduzidas pelo labor no processo da vida. A condição humana do labor é a própria vida", (Arendt, 1999:15).

${ }^{181}$ Cf. o termo utilizado por Maruani, 2002.
} 
dessa forma)? É claro que há exagero e pessimismo neste modo de colocar a questão, pois acaba-se por ignorar a diversidade de esferas que compõem a vida e a identidade dos indivíduos. Mas não posso deixar de apontar que encontrei muitas pessoas que, quando questionadas sobre quais ações seriam necessárias para promover a melhoria da situação atual, me ofereciam como resposta a "misericórdia divina"182. Conceber o presente como o resultado de uma piora progressiva das condições de vida, expressar desconfiança quanto ao horizonte de mudanças e restringir as possibilidades de intervenção sobre a realidade a ação de um deus ex machina me parecem ser respostas às mudanças que revelam os limites à ação humana que estão sendo enxergados neste momento.

É, então, num duplo sentido que a cultura do trabalho é expressão de privação: é privação material pois, como revelado pela fala do motorista de ônibus (Capítulo 3), os ganhos provenientes do trabalho são insuficientes e a precariedade da ocupação torna os trabalhadores vulneráveis aos reveses da sorte; e é também privação no sentido de estar ancorada em valores que pertencem à esfera privada, algo que se torna bastante evidente a partir da maneira com que os entrevistados discorrem sobre sua situação.

Entretanto, é quando tais valores são contrapostos a um outro conjunto de valores e referências que seus significados se esclarecem - é frente à cultura do emprego que esta cultura do trabalho se estabelece e pode ser melhor entendida.

Ainda que as relações de emprego tenham se instituído entre nós da mesma forma que tantos outros direitos, ou seja, realizando a peripécia de se transformar no avesso dos direitos, repondo distinções e privilégios (Telles, 2001), acredito que seja possível dizer que a existência de tais relações também pôs no horizonte do possível a regulação das relações de trabalho referida a um mundo de medidas comuns. Assim, mesmo que não tenha se generalizado de

${ }^{182}$ Quando analisei a narrativa de Fátima, chamei a atenção para este aspecto. 
fato, ampliou a compreensão do que é visto como possível e, neste sentido, contribuiu para alguma desprivatização das relações de trabalho ${ }^{183}$.

Esse aspecto também aparece na fala de todos os entrevistados, independente de serem homens ou mulheres, adultos ou jovens: existe o trabalho e existe o emprego, geralmente relacionado a maior segurança e estabilidade, a relações de trabalho menos arbitrárias e a benefícios sociais.

Como nota José de Souza Martins, "A mera ocupação substitutiva do emprego pode estar no limiar da mendicância, de quem faz apenas o supérfluo, irrelevante e desqualificado, no limiar da condição de descartável. Os trabalhadores rurais e urbanos falam muito em assegurar o 'futuro para os filhos' ou dizem que não ter profissão não dá futuro, que tal trabalho não tem futuro. Portanto, só é legitimamente emprego o trabalho que, além de assegurar o presente, assegure o futuro da família e não de uma só pessoa. Há aí, portanto, a concepção de que o emprego é uma relação de trabalho que assegura a inserção social de, no mínimo, a família conjugal, mas que não raro abranja também a família extensa, como os pais e irmãos, além dos filhos. (...) É a velhice provável e a incapacidade de trabalhar que define o horizonte de significados do emprego" (Martins, 1998: 5). Dessa maneira, o emprego aparece ligado à questão da seguridade - não apenas em relação ao presente mas sobretudo em relação ao futuro.

E, afinal, não é exatamente isso que as narrativas permitem entrever? Notadamente a de Fátima, cuja experiência no mercado formal a torna bastante sensível para compreender os significados do desemprego e os sentido das mudanças: o desalento de Fátima se deve à uma escolha, informada pela avaliação de que não vale a pena dedicar-se a um trabalho que não lhe ofereça os mecanismos de seguridade ligados ao emprego. Ainda que não se sinta completamente satisfeita realizando seus trabalhos voluntários, ela não está disposta a aceitar qualquer trabalho pois sua avaliação está referida a uma medida do que é certo/errado, justo/injusto e o que importa sublinhar é que se trata de uma medida publicamente construída e legitimada.

183 É o que sugere, por exemplo, o processo vivido pelos cooperados, ao qual me referi na Introdução. 
Ao longo dos capítulos, a partir da análise das entrevistas, vinculei a cultura do emprego à noção arendtiana de trabalho ${ }^{184}$, sublinhando justamente que, à diferença da cultura do emprego (que aparece ligada à sobrevivência material e identitária), os valores que estruturam tal cultura não estão restritos ao presente. A cultura do emprego se refere a projetos de futuro, ao desejo de liberação da preocupação constante com o presente e com o futuro. Afinal, é de seguridade que estamos falando: de mecanismos pelos quais a sociedade se responsabiliza pelo destino de seus trabalhadores, o que de certo modo os retira da vivência da constante necessidade. O emprego, com os salários indiretos, os benefícios sociais e mesmo o Fundo de Garantia por Tempo de Serviço, tece (ao menos imaginariamente) uma rede de proteção contra as vicissitudes da vida e, assim, os rendimentos que advém do trabalho assalariado podem se transformar em outra coisa que não apenas atendimento das necessidades imediatas: eles se transformam em reformas na casa, casamento dos filhos, contribuição com a família, planejamento da vida; enfim, transformam-se em "produtos" visíveis, dotados de alguma permanência, construindo elos de ligação entre passado, presente e futuro.

É claro que não se trata aqui de tentar carregar a legislação trabalhista que temos de absoluta positividade, deixando de reconhecer seus efeitos de distinção, suas insuficiências para a criação de relações assalariadas estáveis ou seus aspectos que reforçam o autoritarismo patronal ${ }^{185}$, mas se trata de reconhecer que, sua existência, aliada à experiência de períodos de crescimento econômico e geração de empregos industriais, disseminou um certo horizonte simbólico de integração que opera na organização do mundo do trabalho que hoje se encontra em crise ${ }^{186}$.

\footnotetext{
184 "O trabalho é a atividade correspondente ao artificialismo da existência humana, existência esta não necessariamente contida no eterno ciclo vital da espécie, e cuja mortalidade não é compensada por este último. O trabalho produz um mundo 'artificial' de coisas, nitidamente diferente de qualquer ambiente natural. Dentro de suas fronteiras habita cada vida individual,embora esse mundo se destine a sobreviver e a transcender todas as vidas individuais. A condição humana do trabalho é a mundanidade", (Arendt, 1999:15).

185 Telles, 2001; Troyano, 1991; Paoli, 1989 e Carvalho, 1993.

${ }^{186}$ Em momentos de crise, a importância desse horizonte simbólico se torna mais evidente. É, por exemplo, o que expressa o lamento de dirigentes sindicais ligados à Central Única dos
} 
Além disso, como nota José de Souza Martins, "Boa parte da crise social e pessoal que resulta do desemprego decorre do fato de que o trabalho no mundo contemporâneo foi separado da casa: o lugar de viver é diferente do lugar de trabalhar. Estar empregado significa estar dividido entre a casa e o lugar de trabalho e, também, o lugar de trânsito entre um ponto e outro, a rua. Muitas concepções e relações se estruturaram a partir dessas separações, da definição desses lugares referenciais da vida de todo-o-dia, dessa espacialidade cotidiana. (...) Criou-se um mundo social que depende do emprego para se reproduzir, criar identidades, definir referências. A assimilação da mulher pelo mercado de trabalho também a alcançou mais por aquilo que se pode definir como uma cultura do emprego, mais do que uma cultura do trabalho" (Martins, 1998: 3-4). Aqui também se esclarece a relação entre trabalho/emprego e o mundo da rua: os deslocamentos pela cidade devem estar preenchidos de sentido pelo trabalho (a narrativa de Fátima é, a esse respeito, exemplar). Em situação de desemprego, a não ser quando se trata do esforço da procura, estar na rua significa correr o risco de ser identificado ao universo da vadiagem. Não à toa, todas as narrativas apresentadas aqui falaram desse "ficar em casa" durante a interrupção da procura. O emprego, assim, se diferencia do trabalho no que tem de disciplina, organização do tempo e do espaço, hierarquia, enfim, uma série de rituais que deixam claro que se vive uma relação de trabalho estável, diferente da "viração"187.

As diferenças entre adultos e jovens também se revelaram importantes, contribuindo para elucidar aspectos da cultura do emprego e da cultura do trabalho. Os jovens vivem num momento em que esta cultura do emprego está posta em xeque - eles estão sendo todo o tempo confrontados por especialistas

Trabalhadores que, tendo passado os últimos vinte anos pleiteando pela mudança e pela ampliação da legislação trabalhista, hoje se vêem obrigados a defender as conquistas presentes na legislação em vigor (Seminário Mudança das leis trabalhistas: fragilização do emprego ou caminho para negociação? promovido pelo Centro de Psicologia Aplicada ao Trabalho, Instituto de Psicologia - USP, maio de 2002).

187 Sobre este aspecto ritual do emprego, é interessante notar a situação que aparece no filme "A agenda" (L'emploi du temps, França, 2001). Após perder o emprego, o personagem Vincent, não querendo contar à esposa, continua se vestindo para o trabalho e saindo de casa todos os dias, como se nada tivesse acontecido. Passa-se bastante tempo até que a esposa descubra que algo está errado, o que revela algo sobre a teatralização envolvida nas representações sociais do que é "ser empregado". Sobre este caráter teatral da vida cotidiana, ver Martins, 2000, especialmente o capítulo 2, "O senso comum e a vida cotidiana". 
em recursos humanos que afirmam o fim da era do emprego e o advento de novas relações de trabalho, mais flexíveis e autônomas. Nas falas dos jovens, o caráter privado da experiência do mundo do trabalho se revela com mais nitidez: ao contrário dos adultos, que dispõem de referências (pautadas em sua experiência) que lhes permite avaliar o sentido das perdas, os jovens já tem a instabilidade como a condição normal da experiência de trabalho e assumem, com mais facilidade, o discurso da empregabilidade ${ }^{188}$. Ficam, assim, encalacrados entre as promessas de realização individual (contanto que haja esforços) e a estreiteza das possibilidades que lhes são abertas. Não à toa, os jovens aqui apresentados demonstram grandes doses de realismo - reconhecem a encalacradela em que estão, mas não dispõem de instrumentos legítimos para, pelo menos, afirmar a injustiça das situações vividas: o emprego é artigo raro, é preciso agarrar-se ao que aparecer.

Os adultos, por sua vez, apresentam uma interpretação do presente que está tensionada pelas culturas do emprego e do trabalho - reconhecem que algo está mudando, que as coisas estão mais difíceis e que precisam se localizar de outra maneira neste novo mundo; explicitam sua dificuldade em manter a identidade com o mundo do trabalho já que as diferenças entre trabalhadores e "desocupados" se borram. Os critérios de julgamento deixam de valer e, assim, o longo tempo de desemprego não é sinônimo de vadiagem e a escolaridade não garante o emprego. Ainda assim, são capazes de apontar os sentidos da perda, tendo como referência todos os benefícios ligados ao emprego.

Acredito que as dificuldades de re-localização que os entrevistados adultos trazem à frente da cena sinalizam que as novas formas de relação de trabalho, todas as novidades que a permeiam e a velocidade com que

\footnotetext{
188 Concordo inteiramente com Nadya Guimarães quando chama a atenção para a necessidade de "...despir nosso olhar interpretativo das conotações conjunturais e do debate político que esse conceito despertou entre nós, no Brasil dos anos 90, para refletir sobre a pertinência e valor heurístico daquela formulação original do conceito (cf. Ledrut,1966) como sendo a 'probabilidade, mais ou menos elevada, de que uma pessoa, à procura de emprego, logre obtê-lo'. Por vezes, embora difícil, esse é um útil exercício, especialmente num ramo disciplinar como o da Sociologia do Trabalho cuja agenda de reflexão é tão profundamente devedora da (e emula tão fortemente com a) pauta dos agentes sociais do assim chamado mundo do trabalho", (Guimarães, 2004b: 345). Nesta passagem, no entanto, estou utilizando o termo tal como tem circulado, imbuído assim do sentido de sublinhar a auto-responsabilização do trabalhador desempregado por sua situação.
} 
acontecem, põem em risco a sobrevivência - material e identitária, é certo - mas também põem fim a um modo conhecido de lidar e organizar a sucessão de acontecimentos que constituem a vida. $O$ desalento, então, poderia estar significando sociologicamente esta dificuldade interpretativa do sentido da mudança; dificuldade que é vivida privadamente. O desalento não é, então, apenas uma situação momentaneamente vivida, relacionada à conjuntura do mercado de trabalho e reveladora de desigualdades de acesso à inclusão no mercado de trabalho. Ele é também um momento de uma trajetória de trabalho, e por isso é tão essencial conhecê-la para compreender os significados que esse desalento pode ter, pois a partir do que foi exposto, é possível dizer que o desalento está expressando tensões e esforços de redefinição de identidades e modos de vida ancorados no trabalho.

Mas, se é assim, para que interessa distinguir entre cultura do emprego e cultura do trabalho? Acredito que a compreensão das diferenças existentes entre uma cultura do emprego e uma cultura do trabalho podem contribuir com o debate sobre as novas formas de relação de trabalho que queremos, bem como para a formulação de políticas publicas que tenham como público-alvo os "excluídos" do mercado de trabalho ${ }^{189}$. Sem conhecer os valores e as práticas que estão postos em xeque pelas mudanças, sem ter compreendido e nomeado as formas de conhecer e organizar o mundo do trabalho que temos, sem compreender - portanto - como nos pensamos em relação ao trabalho, colocamos em risco a possibilidade de recriar as relações de trabalho em termos diferentes daqueles que conhecemos, pois não seremos capazes de distinguir entre aquilo que nos é caro e aquilo que não nos importa e, desse modo, estaremos perdendo mais uma vez a chance de construir termos e medidas que estejam enraizados em nossa própria experiência do mundo.

E é preciso falar, então, a respeito daquela segunda região imantada em torno da qual se organizam alguns temas propostos pela pesquisa: os significados que as mudanças das relações entre os indivíduos e o trabalho

189 Para uma importante e oportuna discussão sobre os usos da noção de "exclusão", ver Martins, 2002, "Reflexão crítica sobre o tema da 'exclusão social". 
podem ter para a vida em sociedade. Em torno deste eixo é que gravitou a questão do enraizamento e dos novos espaços de invenção. Defini enraizamento como a pertinência ao mundo produzida pela ação, o que significa que estava interessada em reconhecer espaços nos quais os indivíduos tivessem a experiência da pluralidade e a possibilidade de construir outros significados para o presente, ao mesmo tempo que pudessem tecer e imaginar outras possibilidades - para além daquelas que estão dadas no presente, tal qual os entrevistados o experimentam.

Como apontei na introdução, o tema do enraizamento não aparece nesta dissertação com o mesmo peso que dei à discussão sobre cultura do emprego e cultura do trabalho. E esse desequilíbrio tem sua razão de ser, pois que o campo trouxe à tona elementos que indicam que o presente está sendo vivido como um enigma, privadamente. A ação, como já sublinhei diversas vezes, parece estar fora do horizonte do possível - e isso significa dizer que os indivíduos parecem estar alijados da possibilidade de pensar outras formas de relação com o trabalho. Eles não podem mais viver as relações que conheciam e não encontram chance para se inserir nestas novas configurações do mercado de trabalho. Perplexos, o que toma a frente da cena é a culpabilização pela própria situação, que aparece aqui com um significado bastante próximo aos valores que informam a cultura do trabalho: trata-se de um modo, ainda que perverso, de afirmar sua autonomia e, assim, supor algum controle sobre suas vidas.

Somente a partir das entrevistas, não parece haver espaços nos quais esteja ocorrendo qualquer tipo de invenção; como assinalei, o presente aparece nas falas como resultado de uma piora progressiva, como um tempo-limite. E para modificar o rumo das coisas, somente a intervenção de um deus ex machina é vista como saída.

Isso não significa que eu acredite que não há espaços de invenção; ao contrário, creio que sindicatos, cooperativas, igrejas, associações, organizações não-governamentais e tantas outras formas de organização coletiva têm muito com o que contribuir, na medida em que são atores institucionais que prezam a 
democracia e, portanto, os espaços públicos que produzem - de diferentes maneiras - enraizamentos.

Mas a questão que me propus se refere aos espaços de invenção que tenham o trabalho como eixo, que permitam a criação de sensos comuns e que possam inserir outros horizontes na pauta das discussões sobre o mundo do trabalho. A aproximação com as preocupações de Hannah Arendt se dá por esta razão: estava interessada em pensar os elementos "novos", que pudessem se contrapor aos argumentos e razões que hoje circulam e que conformam a direção das mudanças ${ }^{190}$.

É bastante possível que este "resultado" se deva às características da própria pesquisa, realizada a partir de entrevistas individuais. Mas também é possível que o "resultado" se deva à que a questão realmente foi formulada em termos incisivos: não que seja o caso de desmerecer a criatividade e o "desdobramento" de pessoas como Suely e Demerval, para nomear apenas dois casos que relatei neste trabalho. Mas também é preciso reconhecer que, em termos de questionamento às novas formas de organização que se estabelecem, essa criatividade que resta na esfera privada, se resolve a estruturação da identidade (o que certamente não é pouco), não amplia os horizontes do que é tido como possível. Ao contrário, ela reforça os limites que estão postos.

Quando formulei a questão em termos de enraizamento, procurava identificar espaços nos quais os indivíduos pudessem encontrar nomes para o que estão a viver e que pudessem, também, imaginar novas maneiras de organização, novas divisões de responsabilidades sociais, enfim, estava procurando pelos espaços e pelos termos capazes de inserir novidades na discussão sobre o mundo do trabalho. E isso, de fato, não encontrei.

A reflexão que tem lugar nesta dissertação procurou explicitar que o desemprego por desalento é um momento dentro das trajetórias de trabalho analisadas e que ele se explica não apenas por fatores conjunturais, mas principalmente pelas representações sociais que medeiam a relação dos 
indivíduos com o trabalho. Assim, o desalento - nesse momento - pode estar expressando sociologicamente a dificuldade que os indivíduos encontram para reelaborar suas relações com o trabalho e isso se deve a que tal reelaboração se dá, nas histórias de trabalho que aqui foram analisadas, no espaço privado da vida cotidiana. A velocidade das mudanças e a ausência de espaços públicos de reinvenção das relações com o trabalho acaba tornando o presente um enigma não apenas para os adultos que vivem uma dessocialização ${ }^{191}$ mas também para os jovens, que estão se socializando num mundo no qual as medidas que estão se constituindo reforçam as responsabilidades individuais, abandonando os indivíduos à sua própria sorte.

Nesse momento de rápidas mudanças - ou, para falar como Hannah Arendt, nesse "intervalo de tempo totalmente determinado por coisas que não são mais e por coisas que não são ainda" (Arendt, 2001: 35-6) - ao mesmo tempo em que se procura por novos termos e definições, não me parece de menor importância preencher de significados os termos já surrados, batidos e gastos. Não para reificá-los e seguir utilizando-os como "categorias zumbis"192, mas para apreender neles os valores que orientam nossa relação com o mundo (até para que seja possível escapar dos limites que conformam). Transformações enraizadas e enraizadoras não se fazem senão dialeticamente, daí a necessidade de compreender o presente e construir novos sensos comuns.

A questão que os resultados desta pesquisa deixa em aberto se refere aos espaços de invenção e criação de senso comum, capazes de transformar as relações de trabalho, não apenas "aderindo" às mudanças que já estão em curso, mas imprimindo a tais mudanças sentidos e significados enraizados em modos de conceber a vida socialmente partilhados.

\footnotetext{
191 "Por isso, sociologicamente, o desemprego deve ser examinado como processo social de dessocialização de quem sofre essa ruptura de vínculos e relacionamentos. O desemprego irrompe no cotidiano como uma catástrofe, rompe o cotidiano ao anular as relações sociais de todo dia ou ao mudarlhes o significado. Os grupos de referência mudam de significado ou se alteram, a sociabilidade doméstica e a casa passam a dominar a vida de todo dia. A rua deixa de ser um lugar de passagem, para se tornar um lugar em que se está. A expressão 'estou na rua', 'foi para rua' como sinônimo de desemprego ou de demissão, é bem indicativa do peso negativo da rua numa sociabilidade que tem a casa ainda como referência privilegiada, como se a perda do emprego equivalesse à perda da casa e da família", (Martins, 1999:6).

192 Beck, 1999.
} 


\section{REFERÊNCIAS BIBLIOGRÁFICAS}

ALVIM, Rosilene \& LOPES, José Sérgio Leite (1990) “Famílias operárias, famílias de operárias". Revista Brasileira de Ciências Sociais,ANPOCS, n ${ }^{\circ}$ 14 , ano 5, outubro

AQUILINI, Guiomar de Haro \& COSTA, Patrícia Lino (2003) “O sobre-emprego e a inatividade das mulheres na metrópole paulista". Revista de Estudos Avançados, IEA, volume 17, $\mathrm{n}^{\circ}$ 49, setembro/dezembro, pp.17-34

ARENDT, Hannah (2001) Entre Passado e Futuro: São Paulo, Perspectiva

(1999a) A Condição Humana: Rio de Janeiro, Forense Universitária

(1999b) Eichmann em Jerusalém: um relato sobre a banalidade do mal: São Paulo, Companhia das Letras

Letras

(1989) Origens do totalitarismo: São Paulo, Companhia das (1987) Homens em Tempos Sombrios: São Paulo, Companhia

das Letras

BAJOIT, Guy \& FRANSSEN, Abraham (1997) "O trabalho, busca de sentido". Revista Brasileira de Educação: São Paulo, ANPED, (5-6), maio a dezembro, pp.76-95

BECK, Ulrich (1999) "Goodbye to all that wage slavery - Full Employment". New Statesman: march 5

BESSON, Jean-Louis (org.) (1995) A ilusão das estatísticas: São Paulo, Editora da UNESP

BOLLES, Richard N. (2004) As cinco melhores maneiras de se conseguir um emprego: Rio de Janeiro, Sextante

BOSI, Éclea (1994) Memória e sociedade: lembranças de velhos: São Paulo, Companhia das Letras

(1987) “Cultura e desenraizamento". In: BOSI, Alfredo (1987) Cultura Brasileira - temas e situações: São Paulo, Editora Ática, pp.16-41

CAETANO, Maria Inês (2004) Trajetórias urbanas de moradores de uma favela de um distrito de elite da capital paulista: Tese de doutorado apresentada ao 
Departamento de Sociologia, Faculdade de Filosofia Letras e Ciências Humanas, Universidade de São Paulo

CARUSO, Luiz Antônio C. \& PERO, Valeria (1997) "Empregabilidade e reconversão profissional: trabalhadores desligados da indústria". São Paulo em Perspectiva, 11(1), pp.64-81

CARVALHO, João José Machado de (1993) “Advogados, democracia e direito do trabalho". Introdução Crítica ao Direito do Trabalho, série "O direito achado na rua", vol. 2: Brasília, Editora UnB

CASTEL, Robert (1998) As metamorfoses da questão social: Petrópolis, Vozes

CASTRO, Nadya Araujo; CARDOSO, Adalberto Moreira \& CARUSO, Luiz Antônio. (1997) "Trajetórias ocupacionais, desemprego e empregabilidade: há algo de novo na agenda dos estudos sociais no Brasil?". Contemporaneidade e Educação, 2, pp.7-23

CHIESI, Antonio \& MARTINELLI, Alberto (1997) “O trabalho como escolha e oportunidade". Revista Brasileira de Educação: São Paulo, ANPED, (5-6), maio a dezembro, pp.110-125

COMIN, Álvaro (2003) Mudanças na estrutura sócio-ocupacional no mercado de trabalho em São Paulo. Tese de doutorado apresentada ao Departamento de Sociologia, Faculdade de Filosofia Letras e Ciências Humanas, Universidade de São Paulo

COSTA, Maria Thereza P. (1992) A justiça em ondas médias: o programa Gil Gomes: Campinas, Editora da Unicamp

Da MATTA, Roberto (1991) A casa e a rua: espaço, cidadania, mulher e morte no Brasil: Rio de Janeiro, Guanabara Koogan, (4 edição)

DEMAZIÉRE, Didier (1995a) Le chômage de longue durée: Paris, PUF (1995b) Sociologie du chômage: Paris, La Découverte

DIEESE (2001) A situação do Trabalho no Brasil: São Paulo, DIEESE

(1995) “DIEESE realiza a primeira pesquisa de orçamentos familiares após o Plano Real". http://www.dieese.gov.br, (consultado em 23 de fevereiro de 2004)

DOWBOR, Ladislau. (2001) “O que acontece com o trabalho?” (documento preliminar para discussão: São Paulo, agosto (http://ppbr.com/ld; consultado em 3/2/2002) 
DUBAR, Claude (s/d) "Réflections sociologiques sur la notion d'insertion". In: CHARLOT, Bernard \& GLASMAN, Dominique. Les jeunes, l'insertion, l'emploi": Paris, PUF, pp.29-37

FÉLIX, Cleber, MEYER, Doris R., CASTELLO BRANCO, Helena A. \& PACHECO, Lúcia M. Emprego, subemprego e desemprego: Rio de Janeiro, Fundação IBGE, 1981

FREYSSINET, Jacques (1984), "L'hetérogénéité du phénomène". Le chômage, Paris, La Découverte, pp. 13-56

FRIOT, Bernard (2001) "Rumo à liberdade do trabalho: Responsabilidade e solidariedade na lógica salarial". Tradução de Alain François (mimeo)

GAUTHIER, Madeleine (2000) "L'âge des jeunes: 'un fait social instable". Liens Social et Politiques - RIAC, n. ${ }^{\circ} 43$, printemps, pp. 23-32

\& SINGLY, François de (2000) "Présentation - Voir les jeunes autrement". Liens Social et Politiques - RIAC, n. ${ }^{\circ} 43$, printemps, 58

GOMES, Jerusa Vieira (1997) "Jovens urbanos pobres: anotações sobre escolaridade e emprego". Revista Brasileira de Educação: São Paulo, ANPED, (5-6), maio a dezembro, pp.76-95

GORZ, André (2003) Metamorfoses do trabalho: crítica da razão econômica: São Paulo, Annablume

- (1995) "Saindo da sociedade do trabalho assalariado". São Paulo em Perspectiva, 9 (3)/jul.-set., pp.

(1982) Adeus ao Proletariado: para além do socialismo: Rio de Janeiro, Forense Universitária

GUIMARÃES, Nadya Araujo (2004a) Caminhos Cruzados: estratégias de empresas e trajetórias de trabalhadores: São Paulo, Editora 34/ Curso de Pósgraduação em Sociologia, FFLCH-USP

(2004b) "Do trabalho ao desemprego: contextos societais, construções normativas e experiências subjetivas". Caminhos Cruzados: estratégias de empresas e trajetórias de trabalhadores: São Paulo, Editora 34/ Curso de Pós-graduação em Sociologia, FFLCH-USP pp.331-365 
(2003) "As transformações do (não) trabalho e a Ação Coletiva". Trabalho apresentado no XI Congresso Brasileiro de Sociologia, SBS, Campinas, 1 a 5 de setembro de 2003 (mimeo)

GUIMARÃES, Nadya Araujo; HIRATA, Helena; MONTAGNER, Paula \& WATANABE, Margareth (2003) "Vivendo a Recorrência do Desemprego: Trajetórias e Biografias de Desempregados na Região Metropolitana de São Paulo“. In: GUIMARÃES, N. A. (coord.) Desemprego: Abordagens Institucional e Biográfica. Uma Comparação Brasil, França, Japão. Relatório Científico referente ao Auxílio Pesquisa 469792/00-0, Edital CNPq 01/2000, São Paulo, Fevereiro de 2003. Edição especial em CD-Rom com 8 capítulos, 4 anexos, 591 pp. (mimeo)

HIRATA, Helena (2002a) Nova divisão sexual do trabalho? - Um olhar voltado para a empresa e a sociedade: São Paulo, Boitempo Editorial (escrito com John Humphrey)

(2002b) "Crise econômica e emprego das mulheres: um estudo de caso na indústria brasileira". Nova divisão sexual do trabalho? Um olhar voltado para a empresa e a sociedade: São Paulo, Boitempo Editorial (escrito com John Humphrey), pp.187-194

(2002c) "Trajetória e atividades". Nova divisão sexual do trabalho? - Um olhar voltado para a empresa e a sociedade: São Paulo, Boitempo Editorial (escrito com John Humphrey), pp.173-185

(2002d) "Relações sociais de sexo e psicopatologia do trabalho". Nova divisão sexual do trabalho? - Um olhar voltado para a empresa e a sociedade: São Paulo, Boitempo Editorial (escrito com Danièle Kergoat), pp.233-271

(2002e) "Introdução". Nova divisão sexual do trabalho? - Um olhar voltado para a empresa e a sociedade: São Paulo, Boitempo Editorial, pp.17-26

HIRATA, Helena \& HUMPHREY, John (1989a) “Trabalhadores desempregados: trajetórias de operárias e operários industriais no Brasil". Revista Brasileira de Ciências Sociais, ANPOCS, no. 11, v.4, outubro

(1989b) “Desemprego oculto pelo trabalho precário: operários industriais na Grande São Paulo". São Paulo em Perspectiva, 3 (1/2): 84-91, janeiro/junho

HOFFMANN, Marise B. Pimenta \& BRANDÃO, Sandra M. Chagas (1996) "Estatísticas do Trabalho: análise de algumas práticas internacionais". 
In: Seminários para Repensar o Trabalho, volume 5, Rio de Janeiro, Fundação IBGE, 27 a 31 de maio de 1996

HOWE, Leo (1990) Being unemployed in Northern Ireland: an ethnographic study: Avon, Cambridge University Press

IBGE (2003a) “Notas Metodológicas - a nova PME”. http://www.ibge.gov.br, consultado em 5/6/2003

(2003b) PNAD - 2001. http://www.ibge.gov.br, consultado em $10 / 12 / 2003$

(2002) Pesquisa Mensal de Emprego, Relatórios Metodológicos, v. 23: Rio de Janeiro, IBGE

JARDIM, Fabiana, OTERO, Martina Rillo, SILVA, Mércia C. \& DOWBOR, Monika (2004) "A organização no local de trabalho - Caminhos e desafios do cooperativismo". In: DOWBOR, Ladislau, FURTADO, Odair, TREVISAN, Leonardo \& SILVA, Hélio (orgs.) Desafios do Trabalho: Petrópolis, Vozes, pp.187-207

LEDRUT, Raymond (1966) La sociologie du chômage: Paris, PUF

LEITE, Márcia de Paula (1997) “Qualificação, desemprego e empregabilidade”. São Paulo em Perspectiva, 11(1), pp.64-69

LOPES, José Sérgio Leite (org.) (s/d) Cultura e identidade operária: Rio de Janeiro, UFRJ-Museu Nacional/Marco Zero/Proed

MADEIRA, Felícia Reicher (1993) "Pobreza, escola e trabalho: convicções virtuosas, conexões viciosas". São Paulo em Perspectiva, 7(1), janeiro/março, pp.70-83

MARTINS, Heloísa H. Teixeira de Souza (2004) “A difícil transição: Análise das trajetórias ocupacionais de jovens operários metalúrgicos". In: DOWBOR, Ladislau, FURTADO, Odair, TREVISAN, Leonardo \& SILVA, Hélio (orgs.) Desafios do Trabalho: Petrópolis, Vozes, pp.169-186

(2001) “O processo de reestruturação produtiva e o jovem trabalhador: conhecimento e participação". Tempo Social, Revista de Sociologia da USP, São Paulo, 13 (2), pp. 61-87

(1997) “O jovem no mercado de trabalho". Revista Brasileira de Educação: São Paulo, ANPED, (5-6), maio a dezembro, pp.96-109 
MARTINS, José de Souza (2004) "Que fazer para gerar empregos no Brasil?". Revista de Estudos Avançados, IEA, volume 17, $\mathrm{n}^{\circ} 49$, setembro/dezembro, pp.304-305

Paulus

(2003) Exclusão social e a nova desigualdade: São Paulo, (2002) A sociedade vista do abismo - novos estudos sobre exclusão, pobreza e classes sociais: Petrópolis, Vozes

(2000) A sociabilidade do homem simples: cotidiano e história na modernidade anômala: São Paulo, Hucitec

(1998) “O desemprego na vida cotidiana da região metropolitana de São Paulo" [versão preliminar]: Grupo de Pesquisa sobre o Desemprego - Curso de Sociologia da Vida Cotidiana (mimeo)

MARUANI, Margaret. Les mécomptes du chômage: Paris, Bayard, 2002

MARUANI, Margaret \& REYNAUD, Emmanuèle. "Le chômage". Sociologie de l'emploi: Paris, La Découverte, 1993, pp.

MENDONÇA, Sérgio E. Arbulu \& HOFFMANN, Marise B. Pimenta (1999) “A Pesquisa de Emprego e Desemprego-PED: inovações metodológicas". Emprego e Desenvolvimento Tecnológico: Processos de integração regional: São Paulo, DIEESE

MONTAGNER, Paula (2003) "A medida do emprego e do desemprego nas regiões metropolitanas brasileiras". In: GUIMARÃES, N. A. (coord.) Desemprego: Abordagens Institucional e Biográfica. Uma Comparação Brasil, França, Japão. Relatório Científico referente ao Auxílio Pesquisa 469792/00-0, Edital CNPq 01/2000, São Paulo, Fevereiro de 2003. Edição especial em CD-Rom com 8 capítulos, 4 anexos, 591 pp. (mimeo)

NASSER, Ana Cristina (2003) Sair para o mundo: trabalho, família e lazer na vida dos excluídos: São Paulo, Hucitec/FAPESP

NISBET, Robert A. (1981) “Conservadorismo e Sociologia”. In: MARTINS, José de Souza (org.). Introdução Crítica à Sociologia Rural: São Paulo, Hucitec, pp.

OFFE, Claus (1989) “Trabalho: a categoria-chave da sociologia?". Revista Brasileira de Ciências Sociais, ANPOCS, $\mathrm{n}^{\circ} .10, \mathrm{v} .4$, junho

PAIS, José Machado (2001) Ganchos, Tachos e Biscates: Porto, Âmbar 
(1997) "Introdução". In: PAIS, José Machado \& CHISHOLM, Lynne (coord.) Jovens em mudança - Actas do Congresso Internacional "Growing up between centre and periphery": Lisboa, Instituto de Ciências Sociais da Universidade de Lisboa, Coleção Estudos e Investigações, 10

PAOLI, Maria Célia; SADER, Éder \& TELLES, Vera da Silva (1983) “Pensando a classe operária: os trabalhadores sujeitos ao imaginário acadêmico". Revista Brasileira de História, no 6: São Paulo, ANPUH/ Editora Marco Zero, setembro

PAOLI, Maria Célia (1989) “Trabalhadores e Cidadania: experiência do mundo público na história do Brasil Moderno". Revista de Estudos Avançados: v. 3, $\mathrm{n}^{\mathrm{o}} 7$, set/dez

(s/d) "Os trabalhadores urbanos na fala dos outro: tempo, espaço e classe na história operária brasileira". In: LOPES, José Sérgio Leite. Cultura e identidade operária: Rio de Janeiro, UFRJ-Museu Nacional/Marco Zero/Proed

POLANYI, Karl (1980) A Grande transformação: as origens de nossa época: Rio de Janeiro, Editora Campus

SALAIS, Robert; BAVEREZ, Nicolas \& REYNAUD, Bénédicte. L'invention du chômage: Paris, Presses Universitaires de France, 1986

SANCHES, Solange \& GEBRIM, Vera Lúcia Mattar (2003) "O trabalho da mulher e as negociações coletivas". Revista de Estudos Avançados, IEA, volume $17, \mathrm{n}^{\circ} 49$, setembro/dezembro, pp.99-116

SANTOS, João Bosco Feitosa dos (2000) O avesso da maldição do gênesis: a saga de quem não tem trabalho: São Paulo/ Fortaleza, Annablume/ Secretaria da Cultura e Desporto - Governo do Estado do Ceará

SARTI, Cynthia Andersen (1994) A família como espelho: um estudo sobre a moral dos pobres na periferia de São Paulo: São Paulo, Tese de doutorado apresentada ao Departamento de Antropologia, Faculdade de Filosofia Letras e Ciências Humanas, USP

(1985) É sina que a gente traz (ser mulher na periferia urbana): São Paulo, Dissertação de mestrado apresentada ao Departamento de Ciências Sociais, Faculdade de Filosofia Letras e Ciências Humanas, USP 
SCHEHR, Sébastien (2000) "Processus de singularisation et formes de socialisation de la jeunesse". Liens Social et Politiques - RIAC, n. ${ }^{\circ} 43$, printemps, pp.49-58

SEADE (2002) Pesquisa de Emprego e Desemprego - PED - Apresentação da Base de Dados: São Paulo, CD-ROM

- (1995) PED: conceitos, metodologia e operacionalização: São Paulo, dezembro

SENNETT, Richard (2004) A corrosão do caráter: as conseqüências pessoais do trabalho no novo capitalismo: Rio de Janeiro, Record ( $8^{\text {a }}$ edição)

SINGER, Paul (2000) “O trabalho informal e a luta da classe operária". In: JAKOBSEN, K., MARTINS, R. \& DOMBROWSKI, O. (orgs.): Mapa do Trabalho Informal (Col. Brasil Urgente): São Paulo, Fundação Perseu Abramo

(1998) Globalização e Desemprego: diagnóstico e alternativas: São Paulo, Editora Contexto, $2^{\mathrm{a}}$ ed.

(1985) “A estratégia da sociedade civil no combate ao desemprego". Novos Estudos CEBRAP, São Paulo, n. ${ }^{\circ}$ 11, pp.10-16, jan. 85

SINGLY, François de (2000) "Penser autrement la jeunesse". Liens Social et Politiques - RIAC, n. ${ }^{\circ} 43$, printemps, pp.9-21

SOCHACZEWSKI, Suzanna (1998) A produção da vida: estudo do papel e lugar do trabalho na vida contemporânea: São Paulo, Tese de doutorado apresentada ao Departamento de Sociologia, Faculdade de Filosofia Letras e Ciências Humanas, Universidade de São Paulo

SOUZA, Regina Magalhães de (2003) "Capítulo 4: A individualidade ameaçada" e "Capítulo 5: O aprender como meio de inserção social". Escola e Juventude: o aprender a aprender: São Paulo, EDUC/Paulus/Fapesp, pp.87-166

RODRIGUES, Arakci Martins (1978) Operário, Operária: estudo exploratório sobre o operariado industrial da Grande São Paulo: São Paulo, Símbolo

ROSENTHAL, Eva Doris \& VIANNA, Márcia Coelho de Segadas (1994) Desemprego: uma abordagem conceitual: Rio de Janeiro, IBGE, (Textos para Discussão, v.70)

TAJES, Cláudia (2003) Vida Dura: São Paulo, Editora Planeta do Brasil 
TELLES, Vera da Silva (2001) Pobreza e cidadania: São Paulo, Editora 34/Curso de pós-graduação em sociologia

(1990) “A pobreza como condição de vida: família, trabalho e direitos entre as classes trabalhadoras urbanas". São Paulo em Perspectiva, 4 (2), abril/junho, pp.37-45

THOMPSON, Edward P. (1987) A formação da classe operária inglesa, v.1: Rio de Janeiro, Paz e Terra

TOPALOV, Christian (1994) Naissance du chômeur, 1880-1910: Paris, AlbinMichel

TREVISAN, Leonardo (2004) “Jovens, mentiras e desemprego - Algumas incertezas sobre oferta educacional como receita de felicidade". In: DOWBOR, Ladislau, FURTADO, Odair, TREVISAN, Leonardo \& SILVA, Hélio (orgs.) Desafios do Trabalho: Petrópolis, Vozes, pp.70-77

TROYANO, Annez Andraus (1991) “Flexibilidade do Emprego Assalariado". São Paulo em Perspectiva, 5 (2): 84-95, abril/junho

TROYANO, Annez Andraus et alli (1990) “A trajetória de uma pesquisa: avanços e obstáculos". São Paulo em Perspectiva, 4 (3/4), julho/dezembro, pp. 69-74

(1985a) "A necessidade de uma nova conceituação de Emprego e Desemprego: a pesquisa da Fundação SEADE/DIEESE". São Paulo em Perspectiva, 1 (1), jan./abr., pp. 2-6

(1985b) "Pesquisa de emprego em desemprego SEADE/DIEESE: operacionalização dos conceitos". São Paulo em Perspectiva, 1 (2), maio/agosto, pp. 4-13

Vários autores. (2004) "Que fazer para gerar empregos no Brasil?". Revista de Estudos Avançados, IEA, volume 17, n 49, setembro/dezembro, pp.304317

ZALUAR, Alba (1990) Gênero, cidadania e violência: Campinas, IFICH/Unicamp, coleção Primeira Versão, nº 18

WEIL, Simone (2001) O enraizamento: Bauru, EDUSC

\section{Notícias}

“Desempregados de São Paulo andam a pé, não viajam nem compram roupa”. Folha de São Paulo, 17 de janeiro de 2004, B2 
“Desemprego faz de concurso público 'tábua de salvação'”. Folha de São Paulo, 6 de julho de 2003, B6

"Mulheres obesas de nível superior têm salários menores". http://www.ibest.estadao.com.br, 4/3/2004 (consultado na mesma data)

“O planeta telemarketing”. Veja, 12/02/2004, pp.64-66 


\section{ANEXOS}

\section{Roteiros de Entrevista}

\subsection{Roteiro para primeira entrevista}

Objetivo Geral: Identificar se o entrevistado é acessível e se sua história de trabalho se combina com os objetivos da pesquisa

\section{Objetivos específicos:}

- Identificar tempo de desemprego (mais de doze meses)

- Identificar profissão e formação (início da vida profissional, ocupações ao longo da vida, expectativas quando do início da vida profissional)

- Identificar situação familiar (estado civil, número de filhos)

- Identificar pretensões de recolocação

- Sondar sobre as primeiras estratégias declaradas de desemprego

- Identificar as representações sobre o contexto do próprio desemprego (quais são as causas, quais os fatores que interferem, quais as conseqüências sociais)

- Identificar as representações das conseqüências sobre a própria vida e identidade

- Identificar a rede de informações que o levou ao Centro de Solidariedade

1. Nome, idade, profissão, estado civil e local de residência

2. Tempo de desemprego

3. Como chegou ao Centro de Solidariedade?

4. Situação de perda do emprego

5. Realização de bicos? Quais?

6. Razões às quais credita o longo tempo de desemprego?

7. Já ficou desempregado por um longo tempo antes?

8. O último emprego era na profissão em que começou a trabalhar?

9. Tem amigos, parentes ou vizinhos na mesma situação?

10. Se sim, conversa com eles sobre o assunto?

11. O que identifica como sendo as maiores dificuldades para quem está sem emprego?

12. Com que freqüência procura emprego?

13. Já ficou mais de um mês sem procurar?

14. Se sim, quais foram os motivos que o levaram a "dar um tempo"?

15. Como analisa o mercado de trabalho do qual saiu?

16. Nota alguma diferença no comportamento das pessoas que continuaram trabalhando no local de onde saiu?

17. Como fica a relação com a família?

18. Costumava passar bastante tempo em casa antes da sair do emprego?

19. Já se mudou de cidade desde o início do período de desemprego?

20. Já pensou em se mudar? Quais os motivos?

21. Tem parentes que moram na mesma cidade? Recorre a eles? 
22. Como costuma procurar emprego? Por meio dos classificados, rádio, $\mathrm{TV}$, amigos que dão a dica? Geralmente vai sozinho ou vai com alguns amigos?

23. Realiza algum "ritual" antes de sair para procurar emprego? (orações, jeitos diferentes de se arrumar? Pede para parentes rezarem por ele?)

24. Dentre as vagas que já foi procurar, alguma vez teve a sensação de que aquela vaga seria sua? Por que?

25. Quais as mudanças que sente em relação à época em que trabalhava?

26. Quando começou a trabalhar?

27. Antes de começar a trabalhar, o que sonhava em fazer?

28. Qual é a profissão dos pais?

29. Se lembra do que costumava ouvir sobre trabalho quando era criança?

30. E hoje em dia, o que acha que significa o trabalho?

31. Acha que existem diferenças entre trabalho e emprego?

32. Percebeu alguma mudança na atitude dos vizinhos?

33. Gostaria de ter feito outras escolhas em sua trajetória profissional? Quais? Como isso poderia tê-lo levado a uma situação diferente?

34. Como acha que seria possível resolver a questão do desemprego?

35. Pensando nos exemplos que ele conhece, quais são as conseqüências do desemprego?

36. Como ele acha que os jovens lidam com a questão do trabalho e do emprego?

37. Qual era a rotina dele antes de sair do emprego?

38. E hoje em dia?

39. Quais as pessoas que ele mais encontra?

40. É religioso?

41. A relação com a mulher e com os filhos ficou muito diferente? Como?

42. Como aconselharia o próximo presidente a resolver o problema do emprego?

43. Existe alguma época do ano que seja mais difícil estar desempregado? Qual? Por que?

44. Mantém o mesmo grupo de amigos com os quais trabalhava?

45. O que faz nas horas de descanso?

46. Acha que antigamente as coisas eram diferentes? Identifica algum momento, na história recente, em que as coisas começaram a mudar?

47. Gostaria de dizer mais alguma coisa? Acha que faltou perguntar alguma coisa ou que alguma coisa não deveria ter sido perguntada?

\subsection{Roteiro para entrevista com Fátima}

Objetivo Geral: Recolher as histórias de vida, em todos os seus aspectos relevantes e reveladores para o tema dessa pesquisa e com o máximo de detalhes possível, que possibilitem a construção das narrativas de trabalho a serem analisadas na dissertação.

\section{Objetivos Específicos:}


- Conhecer a relação da pessoa com seu trabalho (sem o quê, todas tentativas de interpretações perdem o sentido);

- Conhecer sua trajetória de trabalho;

- Identificar, nessa trajetória, os momentos de desemprego;

- Identificar se já houve período de desalento em desemprego anterior;

- Identificar, no tempo desse último desemprego, o momento da desistência da procura;

- Conhecer as razões que levaram à desistência;

- Conhecer as razões que fizeram voltar a procurar (uma vez que o contato comigo se deu num momento de procura de trabalho);

- Conhecer a avaliação que a pessoa faz do mercado de trabalho;

- Conhecer a avaliação que a pessoa faz de suas possibilidades de trabalho;

- Levantar elementos que nos auxiliem a pensar a distinção entre cultura do emprego e cultura do trabalho

\section{Aspectos da história de vida:}

- Questão de gênero - casamento, filhos, papel familiar

- Identificação com o trabalho

- Idade

- Religiosidade

- Momento de entrada no mercado de trabalho

\section{Questões}

\section{Caracterizar a situação - desemprego oculto pelo desalento}

1. Quando perdeu o emprego?

2. Quais foram as razões que levaram à saída do emprego?

3. Depois que saiu, logo em seguida começou a procurar ou esperou durante um tempo (por causa do seguro-desemprego, por exemplo)?

4. E desde então, o que tem feito?

5. Consegue se lembrar com detalhes do período em que decidiu parar de procurar?

6. Como ficou o uso do tempo naquela época?

7. Quando nos encontramos, você estava procurando. Voltou a procurar, exerceu algum trabalho desde então?

\section{Trajetória de Trabalho}

1. Sua família é do interior de Minas, não é? Quando você vieram para cá? Quantos anos você tinha?

2. Com quantos anos começou a trabalhar?

3. Era registrado?

4. Já estava casada?

5. o que significou para você ter começado a trabalhar?

6. Você sonhava em ter alguma profissão, especificamente? 
7. Você sente que tem muita diferença, em relação a quando você começou a trabalhar, nos planos que as pessoas fazem e no momento em que começam a trabalhar?

8. E depois do primeiro trabalho, o que fez?

9. Quanto tempo demorou a encontrar outro trabalho?

10. Também trabalhava registrada no novo trabalho?

11. Acha que tem alguma razão pela qual dessa vez foi mais difícil encontrar um novo trabalho? Qual?

12. Sente muita diferença desde a época em que trabalhava? Quais são as maiores?

13. Seu marido sempre trabalhou na indústria?

14. Quando se casou, seu marido não implicou com seu trabalho?

15. Seu marido era metalúrgico. Há quanto tempo ele se aposentou?

16. Foi por tempo de serviço?

17. Ele gostaria de voltar a trabalhar?

18. E você? Continua desejando encontrar um novo trabalho? Por que?

19. Você acha que o desemprego é diferente para o homem e para a mulher. No que?

20. Você acha que é mais sofrido para um do que para o outro?

21. Como você vê isso acontecer na sua casa, ou com amigos e vizinhos?

22. Depois de quanto tempo depois que você tinha saído do seu último trabalho você decidiu voltar a estudar?

23. Você voltou a estudar porque achou que era um fator que ajudaria a conseguir um novo emprego?

24. Você disse que não gosta de ficar em casa, parada. Como você tem ocupado seu tempo?

25. Sua família mora perto de você?

26. Houve mudanças nas relações com eles, desde que você parou de trabalhar?

27. Você ainda tem família em Minas?

28. Já pensou em se mudar de cidade, ir para uma cidade que esteja atraindo as indústrias que saíram daqui? Por que? Quando?

29. Você falou, várias pessoas também me disseram, da diferença entre ter ou não "cabeça fraca". O que significa ter cabeça fraca?

30. E na Igreja, vocês têm discutido sobre a situação do desemprego? Teve uma Campanha da Fraternidade, de 1999, "Sem trabalho, por que?", você se lembra das discussões?

31. Você comentou que ter fé é muito importante nessas horas difíceis, como num momento de desemprego. Como você acha que a fé ajuda as pessoas? Como você acha que ela te ajudou?

32. Você está dando aulas de pintura para crianças, não é? O que mais você tem feito ultimamente?

33. E não há notícias sobre o processo que vocês moveram contra a empresa?

34. Você me falou da diferença que sente na cidade, nos galpões que hoje estão abandonados. Quando você acha que esse esvaziamento começou a acontecer? 
35. Você tinha me contado de um sonho, no qual estava numa fábrica e dentro do galão corria um esgoto a céu aberto, que era necessário cobrir, mas as coisas ficavam daquele jeito. Você continua tendo sonhos sobre trabalho?

\subsection{Roteiro para entrevista com José}

Objetivo geral: aprofundar os temas mais relevantes a serem tratados a partir da entrevista.

\section{Objetivos Específicos:}

- Conhecer a relação da pessoa com seu trabalho (sem o quê, todas tentativas de interpretações perdem o sentido);

- Conhecer sua trajetória de trabalho;

- Identificar, nessa trajetória, os momentos de desemprego;

- Identificar se já houve período de desalento em desemprego anterior;

- Identificar, no tempo desse último desemprego, o momento da desistência da procura;

- Conhecer as razões que levaram à desistência;

- Conhecer as razões que fizeram voltar a procurar (uma vez que o contato comigo se deu num momento de procura de trabalho);

- Conhecer a avaliação que a pessoa faz do mercado de trabalho;

- Conhecer a avaliação que a pessoa faz de suas possibilidades de trabalho;

- Levantar elementos que nos auxiliem a pensar a distinção entre cultura do emprego e cultura do trabalho

\section{Aspectos da história de vida:}

- Papel familiar - o masculino

- Idade

- Não ter uma profissão - apesar de trabalhar na roça desde pequeno e registrado desde os 23 anos. Profissão é algo que se aprende e que fica com você, algo de constante, algo que existe independente de uma empresa especifica. De um certo modo, está ligada à procura pela garantia de futuro; talvez de uma maneira que se cola mais à realidade do que os discursos de empregabilidade.

\section{Questões}

\section{Trajetória}

1. O senhor começou trabalhando na roça, no Paraná, não é? Com quantos anos o senhor começou a trabalhar?

2. E o senhor veio para cá com quantos anos?

3. Tinha família aqui?

4. Qual foi o primeiro emprego que o senhor arranjou?

5. Quanto tempo o senhor permaneceu nesse emprego?

6. E então? Quais foram os outros trabalhos que o senhor fez? (prestar atenção às datas) 
7. Já participou de sindicato?

8. O senhor consegue localizar no tempo um momento após o qual encontrar um emprego passou a ser mais difícil?

9. Quais as razões que o senhor atribui a isso?

10. O senhor se casou com quantos anos?

11. A esposa do senhor sempre trabalhou?

12. O que ela faz hoje?

13. Como foi receber a notícia de que ia ficar sem emprego?

14. Como foi dar a notícia, em casa? Para os amigos?

15. Quando alguém pergunta "o que você faz", qual a resposta?

16. O senhor sempre trabalhou registrado?

17. É a primeira vez que o senhor fica tanto tempo desempregado?

18. Chegou a fazer bicos?

19. No que um emprego é diferente de um bico?

\section{O problema do desalento}

1. O senhor está sem trabalho há um ano e cinco meses. Em algum outro momento da sua vida o senhor ficou esse tempo sem trabalho?

2. Como o senhor tomou a decisão de parar por um tempo de procurar?

3. E a sua esposa o apoiou nessa decisão?

4. O senhor comentou que nos primeiros dias foi difícil ficar em casa, sem sair para procurar. Tinha alguma coisa que era mais difícil? Algum momento dia que era mais difícil estar em casa?

5. O senhor conversou com outras pessoas durante o período em que parou de procurar?

6. Sentiu algum julgamento de vizinhos, família, etc? Como lidou com isso?

7. Você acha que tem "um tipo" de pessoa que está mais arriscado a perder o emprego ou que, se perdesse o emprego, teria mais dificuldade em encontrar outro?

8. Como os seus filhos estão compreendendo essa situação?

\section{Gênero}

1. O senhor acha que tem diferenças em estar desempregado entre homens e mulheres? Quais?

2. A esposa do senhor já esteve desempregada?

3. Sua mãe trabalhava junto com seu pai?

4. O senhor tema amigos, colegas que também estão procurando trabalho? $\mathrm{O}$ que eles contam? O senhor acha que as formas de encarar o desemprego são parecidas ou muito diferentes?

5. Como o senhor pensava o seu futuro profissional quando era criança? $\mathrm{O}$ senhor se lembra? Lembra-se do que seus pais lhe diziam?

6. O senhor acha que trabalhar é mais importante para o homem do que para a mulher? 
7. O senhor comentou que, agora que estava em casa, estava fazendo "o serviço que sua esposa deveria fazer". Quais são os trabalhos de mulher? E quais são os trabalhos de homem?

\section{Bairro}

1. O senhor mora nesse bairro há muito tempo?

2. Sente mudanças? Quais?

3. Conhece bem a cidade? O que acha que mudou desde que veio para cá?

4. Conhece vizinhos? Costumam se encontrar? Conversar?

5. Freqüenta alguma Igreja ou associação de bairro?

\section{Geração}

1. Quais as preocupações que o senhor tem em relação a sua filha e aos seus netos?

2. O senhor observa os amigos da sua filha?

3. Como acha que eles se relacionam com o trabalho?

4. O que o senhor tenta ensinar para a sua filha, sobre a vida profissional?

5. A sua filha que é casada trabalha fora?

6. O senhor acha que os jovens têm menos dificuldades para encontrar emprego?

7. Qual seria a "idade certa" para que não fosse tão difícil conseguir um novo trabalho?

\subsection{Roteiro para entrevista com Suely}

Objetivo Geral: Recolher as histórias de vida, em todos os seus aspectos relevantes e reveladores para o tema dessa pesquisa e com o máximo de detalhes possivel, que possibilitem a construção das narrativas de trabalho a serem analisadas na dissertação.

\section{Objetivos Específicos:}

- Conhecer a relação da pessoa com seu trabalho (sem o quê, todas tentativas de interpretações perdem o sentido);

- Conhecer sua trajetória de trabalho;

- Identificar, nessa trajetória, os momentos de desemprego;

- Identificar se já houve período de desalento em desemprego anterior;

- Identificar, no tempo desse último desemprego, o momento da desistência da procura;

- Conhecer as razões que levaram à desistência;

- Conhecer as razões que fizeram voltar a procurar (uma vez que o contato comigo se deu num momento de procura de trabalho);

- Conhecer a avaliação que a pessoa faz do mercado de trabalho;

- Conhecer a avaliação que a pessoa faz de suas possibilidades de trabalho;

- Levantar elementos que nos auxiliem a pensar a distinção entre cultura do emprego e cultura do trabalho 


\section{Aspectos da história de vida:}

- Carreira profissional e carreira reprodutiva

- Gênero: ser mãe, mulher e esposa ao mesmo tempo que trabalhadora

- Preconceitos: os concursos como maneira de driblá-los

- As preocupações em relação ao filho

- O retorno ao mercado de trabalho

- Os significados do lazer

\section{Questões}

\section{Trajetória}

1. Começou a trabalhar com 16 anos, não é?

2. O seu primeiro trabalho foi numa tecelagem e, depois, você entrou numa metalúrgica?

3. E quanto tempo permaneceu nele?

4. Quanto tempo você ficou trabalhando na indústria? E como consegui um novo emprego quando perdia o anterior?

5. Você comentou que abriu uma bombonière, com a qual ficou quatro meses trabalhando? Onde era? Por que você acabou fechando? Foi a única experiência em abrir um negócio próprio?

6. Qual foi o máximo de tempo que você ficou em um mesmo emprego?

7. E o período mais curto?

8. Você fez bicos apenas desta última vez em que ficou desempregada (quando conversamos da primeira vez) ou de vez em quando você fazia alguma coisa?

9. Qual foi o período mais longo de tempo que você ficou desempregada?

10. Você parou de trabalhar após o parto de seus dois filhos. Você sentiu dificuldade de recomeçar a trabalhar?

11. Você começou a trabalhar aos 16 anos. Quanto tempo ficou no primeiro emprego? E depois?

12. Você sempre trabalhou com registro em carteira?

13. Quando você saiu da indústria para trabalhar no comércio? Teve algum motivo?

14. Na primeira entrevista, você disse que se pudesse voltaria a trabalhar em metalúrgicas. E hoje, tem alguma área que você prefira para trabalhar?

15. Você comentou que uma mulher separada precisa trabalhar mais do que um homem solteiro. Como é isso? O que define a "necessidade"? Quem você acha que precisa mais? E quem precisa menos?

16. Você comentou que os seus colegas de escola que trabalhavam, trabalhavam há bastante tempo no mesmo lugar. Você acha que permanecer no mesmo emprego é um fator importante, até para conseguir um outro trabalho depois?

\section{O problema do desalento}

1. Quando havíamos nos falado, você disse que parou por um tempo de procurar. Foi por causa da volta à escola ou teve algum outro motivo? 
2. Quanto tempo durou o período de não procurar?

3. E durante o período em que não procurava, como era ficar em casa?

4. Sentia cobranças de família ou vizinhos? Como lidava com isso?

5. E como foi a decisão de parar de procurar?

6. E como foi a decisão de voltar a procurar?

7. Você disse que ficar em casa, parada, era ruim, pois era mais fácil "pensar besteiras". Que besteiras são essas?

8. Você comentou que a dificuldade em encontrar um novo trabalho não era só sua, mas da crise geral, mundial. Como é essa crise? Você acha que ela tem diminuído? Percebe alguma mudança?

9. E desde que nos falamos, você voltou a procurar?

10. Quando eu te perguntei há quanto tempo você estava procurando, você me perguntou de volta, há quanto tempo estava procurando ou estava desempregada. Qual é a diferença?

11. Você comentou que, anteriormente, se procurava emprego em porta de fábrica, por meio das placas, e hoje em dia, quais são as formas novas de procurar?

12. Você também fez bicos, não é? Quais foram os bicos que fez?

13. Você terminou o colegial?

\section{Gênero}

1. Com quantos anos se casou?

2. Na primeira entrevista, você disse que seu marido implicava com o seu trabalho, mas mesmo assim você voltou a trabalhar depois do nascimento do seu primeiro filho. Você gostava de trabalhar? Você e seu ex-marido chegaram a conversar sobre a sua volta ao trabalho? Por que você acha que ele não queria que você trabalhasse?

3. Seu ex-marido é concursado na PM? Ele nunca esteve desempregado?

4. E depois que você teve o segundo filho, você também parou de trabalhar por um período?

5. Por que você acha que é importante trabalhar?

6. Você acha que é diferente para o homem e para a mulher, ficar desempregado?

7. Você havia dito, na primeira entrevista, que achava que a obesidade é um fator que dificulta conseguir um emprego. Você acha que isso atinge homens e mulheres igualmente?

8. Na época da primeira entrevista, sue filho estudava à tarde. Ele continua estudando à tarde?

9. Você ficou preocupada em não conseguir pagar a escola?

10. Seu ex-marido ajuda nas despesas de casa?

11. Você disse que a mulher está trabalhando e está pensando no filho. Os homens também são pais. Qual você acha que é a diferença? Eles não se preocupam? Ou a preocupação deles é diferente?

12. A sua irmã, que trabalhava em metalúrgica, ela continua trabalhando? Se continua trabalhando, é na mesma área? Ela é casada? 
13. Você disse que dizia que seu filho ficava com sua mãe, para que os empregadores não pensassem que você não poderia trabalhar "direito". Quando você começou a usar essa estratégia? Você percebeu que era melhor ou alguém te deu a dica?

14. Você também comentou que, nas filas, eram as mulheres que falavam mais de assuntos pessoais, ou dos filhos ou das coisas que acontecem dentro de casa. Por que você acha que isso acontecia?

\section{Concursos}

1. Você continuou prestando concursos, desde que nos falamos?

2. Se sim, para quais vagas?

3. Você pretende continuar prestando concursos, mesmo após ter conseguido um novo emprego?

4. Você disse que o que era positivo no concurso era que não era preciso confiar na simpatia do empregador. Você acha que, nesse momento, a situação está melhor do que há um ano, quando nos falamos a primeira vez?

5. Depois da primeira entrevista, disse a você que achava absurdo que uma mulher jovem e bonita acabasse se sentindo mal ao procurar trabalho, acreditando que as dificuldades se devessem também à aparência. Você me disse que, infelizmente, ainda que absurdo, é assim que as coisas são. Você continua achando que as coisas são assim?

\section{A volta ao trabalho e seus significados}

1. Faz um mês que você voltou a trabalhar. Como você conseguiu esse emprego?

2. Qual é o trabalho que você está fazendo?

3. Você gosta de trabalhar perto de casa?

4. Já tinha, antes, trabalhado tão perto de casa?

5. E como foi voltar a ter uma rotina de trabalho?

6. Como seus filhos reagiram à notícia?

7. Qual foi o tempo total de desemprego, antes desse novo emprego?

8. Você tem alguma preocupação agora, em relação ao novo trabalho? Você disse que no início, quando alguém ficou procurando por muito tempo, a pessoa pode se sentir insegura, e não corresponder às expectativas do patrão. Você sentiu essa dificuldade?

\section{Os significados do lazer}

1. Você disse que não conseguia descansar, a não ser que estivesse dormindo. Depois que você voltou a trabalhar, isso mudou?

2. O que você faz, agora, para descansar?

3. Você também disse que não gostava de assistir televisão, a não ser jornal, reportagens e coisas que pudessem te instruir. Agora, que você está trabalhando, você continua gostando desses programas?

4. E os livros? Você consegue ler?

5. E cuidar da horta? Jogar vôlei com seu filho e os amigos dele?

6. Você disse gostar de coisas que te instruem. O que você acha que te instrui hoje, agora que você voltou a trabalhar? 